\title{
Kultura prawna państw azjatyckich
}

Redakcja naukowa

Joanna Marszałek-Kawa Marcin Górnikiewicz 


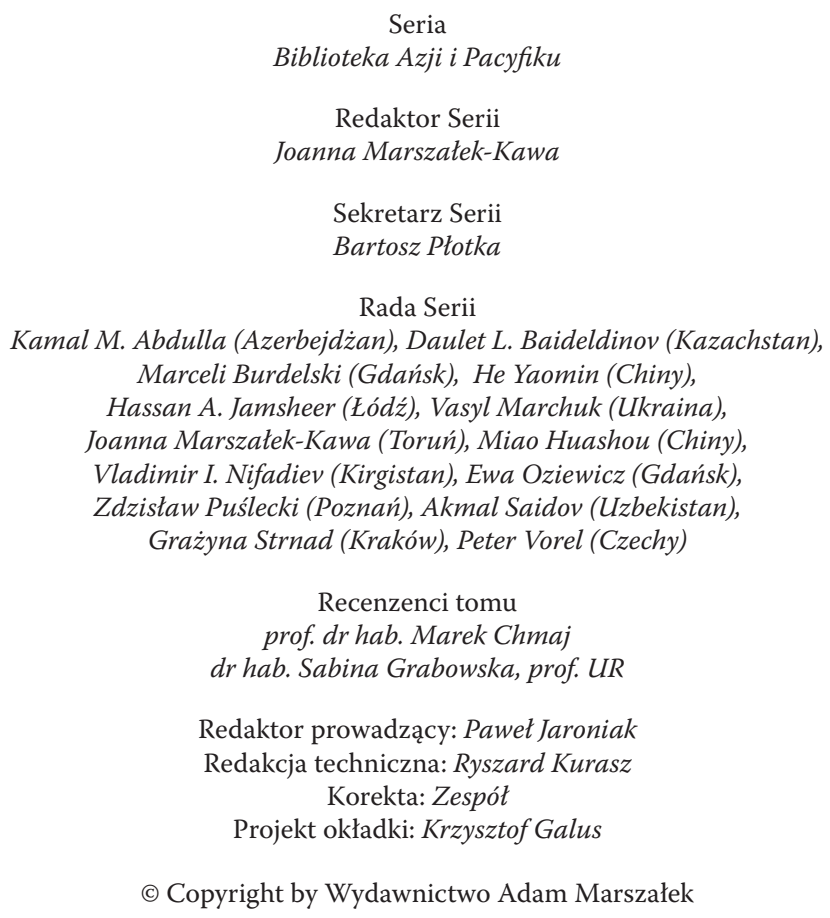

Wszystkie prawa zastrzeżone. Książka, którą nabyłeś, jest dziełem twórcy i wydawcy. Żadna jej część nie może być reprodukowana jakimkolwiek sposobem - mechanicznie, elektronicznie, drogą fotokopii itp. - bez pisemnego zezwolenia wydawcy. Jeśli cytujesz fragmenty tej książki, nie zmieniaj ich treści i koniecznie zaznacz, czyje to dzieło

Toruń 2020

ISBN 978-83-8180-309-0

Publikacja dofinansowana przez Wydział Bezpieczeństwa, Logistyki i Zarządzania WAT

Wydawnictwo prowadzi sprzedaż wysyłkową:

tel./fax 566485070 , marketing@marszalek.com.pl

Wydawnictwo Adam Marszałek, ul. Lubicka 44, 87-100 Toruń

tel. 56 664. 22 35, 5666081 60, e-mail: info@marszalek.com.pl, www.marszalek.com.pl

Drukarnia, ul. Warszawska 54, 87-148 Łysomice, tel. 566783478 


\section{Spis treści}

Wstęp

\section{Magdalena Kręgiel, Magdalena Lewicka}

Normatywne podstawy ochrony praw człowieka w świecie arabskim. Al-Mītāà al-'Arabì li-Huqūq

al-Insān (Arabska Karta Praw Człowieka)

\section{Aleksandra Raba-Schulze}

Równość płci a status kobiet w Chinach

\section{Agnieszka Magdalena Kociemba}

Prawa kobiet w Turcji. Omówienie wybranych aspektów ....... 91

\section{Ksenia Kakareko}

Państwo i prawa człowieka w nauce społecznej Kościoła prawosławnego

\section{Bolesław Sprengel}

Przestępczość Azjatów w Polsce

\section{Jerzy Szukalski}

Sądownictwo polubowne w państwach Azji Centralnej 
Natalia Ciszewska

Od Gułagu do globalizacji, czyli rzecz o ewolucji rosyjskojęzycznej przestępczości zorganizowanej 209

Maria Gołda-Sobczak

Prawo autorskie Federacji Rosyjskiej 230 


\section{Wstęp}

Kultura prawna państw azjatyckich to temat sięgający znacznie dalej niż spisane systemy normatywne. Korzeni należy szukać jeszcze w prawie zwyczajowym, a nawet w tych podstawach kulturowych, które to prawo kształtowały. Azja to olbrzymi obszar zamieszkiwany przez tysiące różnorodnych grup etnicznych i narodowych. Ograniczając się jedynie do państw współcześnie istniejących, nadal mówimy o wielu zróżnicowanych wewnętrznie społeczeństwach, których wielowiekowy dorobek kulturowy wpłynął nie tylko na obecny kształt prawa, ale również na jego rozumienie, wykładnię i stosowanie. Przykładowo, w starożytnych i feudalnych Chinach funkcjonowała klasa mandarynów, czyli urzędników państwowych, którzy byli wyłaniani w drodze ogólnopaństwowych egzaminów. Innymi słowy, statusu mandaryna nie można było odziedziczyć, jak miało to miejsce w przypadku klas wojowników (rycerzy) rządzących większością feudalnych społeczeństw. Mandaryn był nie tylko urzędnikiem, ale również uczonym reprezentującym wysoki poziom zarówno nabytej wiedzy, jak i wrodzonej inteligencji. W oparciu o tę wiedzę oraz własne doświadczenie mandaryni wydawali wyroki, tym samym występując w roli sędziów obdarzonych prawem do samodzielnego interpretowania prawa lub wypełniania istniejących luk stosowanie do własnego uznania i sytuacji. Wyobrażenie sobie, jak takie podejście do stosowania prawa mogło kształtować postawy społeczne, może być swoistym impulsem do uświadomienia sobie skali różnic między Chinami a pozostałą czę- 
ścią Azji. W feudalnej Japonii - podobnie jak w Europie - panowała w tym czasie klasa wojowników, przy czym na gruncie japońskim pozycja społeczna tej klasy była znacznie wyższa i sytuowała samuraja w roli niemal półboga. Tutaj również panowały złożone normy zwyczajowe, w przypadku klasy wojowników oparte o kodeks bushido („drogi wojownika”). Można oczywiście przyjąć, że tak dawne dzieje nie mają już żadnego odzwierciedlenia w realiach współczesności. W przypadku społeczeństw europejskich zaliczanych do tzw. kultur krótkoterminowych rzeczywiście nie jest łatwo odnaleźć widoczne konotacje między procesem formowania się prawa w feudalizmie a obecnie obowiązującymi systemami prawnymi. Natomiast większość społeczeństw azjatyckich zalicza się jednak do kręgu kultur długoterminowych. W Chinach rola nauczyciela, urzędnika i sędziego nadal cieszy się olbrzymim autorytetem społecznym, podobnie jak we współczesnej Japonii szacunkiem darzeni są przedstawiciele formacji mundurowych, urzędnicy, a nawet członkowie "yakuzy”, kojarzonej ze spadkobiercami tradycji samurajów. Zatem rola sędziego w krajach azjatyckich również cieszy się większym uznaniem niż w większości społeczeństw europejskich. Azjaci ponadto przejawiają większą spolegliwość w postępowaniu zgodnie z obowiązującymi normami (dla członków „yakuzy” jest to wewnątrzorganizacyjne "prawodawstwo”), w stosowaniu się do wprowadzanych nakazów i zakazów. Doskonałym przykładem jest tragiczna w skutkach epidemia koronawirusa, której przebieg w większości państw azjatyckich jest stosunkowo łagodny w przeciwieństwie do tych państw, w których społeczeństwa nie nawykły do masowego i niemal restrykcyjnego przestrzegania jakichkolwiek odgórnie narzucanych norm. Konkludując, można przyjąć, że równie ważne jak precyzja i wewnętrzna spójność jakiegokolwiek prawodawstwa jest społeczne nastawienie do jego przestrzegania. $Z$ tego względu niniejsza pozy- 
cja traktująca o wybranych przypadkach relacji zachodzących między społeczeństwem a normami prawnymi może zyskać uznanie czytelników interesujących się egzotycznym wymiarem azjatyckiej kulturowości. Miłej lektury!

Joanna Marszałek-Kawa

Marcin Górnikiewicz 

Magdalena Kręgiel

Akademii Sztuki Wojennej

Magdalena Lewicka

Uniwersytet Mikołaja Kopernika w Toruniu

\section{Normatywne podstawy ochrony praw człowieka w świecie arabskim. Al-Mītāa $q$ al-Arabì li-Huquàq al-Insān (Arabska Karta Praw Człowieka)}

\section{Wprowadzenie}

Do pochylenia się nad prawami człowieka doprowadziły społeczność międzynarodową wielkie konflikty - w tym przede wszystkim II wojna światowa - które przyczyniły się do śmierci wielu ludzi, rozdzielenia rodzin, niegodnego traktowania mniejszości narodowych oraz szeregu innych krzywd i naruszeń, które legły u podstaw podjęcia rozważań na temat konieczności zapewnienia jednostkom i narodom ich podstawowych praw. Pierwszym z dokumentów powstałych w rezultacie tych rozważań była Powszechna Deklaracja Praw Człowieka z 1948 r., uchwalona przez Organizację Narodów Zjednoczonych. Wejście w życie tego do aktu stworzyło podwaliny pod rozwój systemów ochrony praw człowieka o zasięgu lokalnym, regionalnym i międzynarodowym ${ }^{1}$, w oparciu o akty norma-

1 Międzynarodowy System Ochrony Praw Człowieka (International System of Human Rights Protection) tworzy przede wszystkim Organizacja Narodów Zjednoczonych (United Nations), w tym Rada Gospodarcza i Spo- 
tywne i instytucje stojące na straży implementacji zawartych w nich zasad i norm. Dość wymienić: system europejski oraz obowiązującą w tym regionie Konwencję o ochronie praw człowieka i podstawowych wolności zawartą przez miasta zjednoczone w ramach Rady Europy, system amerykański i powstałą na potrzeby ochrony praw człowieka Amerykańską konwencję praw człowieka uchwalona przez Organizację Państw Amerykańskich, system afrykański oraz sporządzoną przez Organizację Państw Afrykańskich Afrykańską konwencję o ochronie praw człowieka i ludów, wreszcie - dokument, który jest przedmiotem badań omówionych w niniejszej pracy, tj. Arabska Karta Praw Człowieka uchwalona przez państwa Bliskiego Wschodu i Afryki Północnej zrzeszone w Lidze Państw Arabskich.

Specyfika muzułmańskiego kręgu kulturowego, mocno osadzona w religii i tradycji tego obszaru, sprawia, że zachodnie normy prawne i dokumenty o zasięgu międzynarodowym nie są w stanie - jak się wydaje - zapewnić odpowiedniej ochrony jednostce. Koran - święta księga wyznawców islamu - reguluje nie tylko wszystkie aspekty życia religijnego, ale dotyka także społecznego oraz politycznego wymiaru funkcjonowania państwa i jednostki w świecie muzułmańskim. Nierzadko stanowi to istotną przeszkodę w ratyfikacji przez państwa arabskie (czy szerzej: muzułmańskie) uniwersalnych dokumentów w zakresie ochrony praw człowieka. Próbą rozwiązania tego problemu,

łeczna (The Economic and Social Council), Komitet Praw Człowieka (Human Rights Committee), Komitet ds. Praw Gospodarczych, Społecznych i Kulturalnych (Committee on Economic, Social and Cultural Rights) oraz urząd Wysokiego Komisarza Narodów Zjednoczonych ds. Praw Człowieka (United Nations High Commissioner for Human Rights). Podstawowymi aktami normatywnymi dla tych organów są: Karta Narodów Zjednoczonych (United Nations Charter), Powszechna Deklaracja Praw Człowieka (Universal Declaration of Human Rights) oraz Międzynarodowe Pakty Praw Człowieka (International Covenants on Human Rights). 
a zarazem próbą unormowania tychże kwestii było ustanowienie szeregu mechanizmów ochrony tychże praw w ramach powołanej w 1945 r. Ligi Państw Arabskich (Ğāmíat ad-Duwal al-'Arabiyya), począwszy od Stałej Komisji Arabskiej ds. Praw Człowieka (Al-Lağna al-'Arabiyya ad-Dā'ima li-Huqūq al-Insān) utworzonej w 1968 r. przy Sekretariacie Generalnym (Al-Amāna al-'Ámma) Ligi'², poprzez powołaną w 2005 r. Komisję ds. Ustawodawczych, Prawnych i Praw Człowieka (Lağnat aš-Šu'ūn at-Tašrī'iyya wa-al-Qānūniyya wa-Huqūq al-Insān) Parlamentu Arabskiego (Al-Barlamān al-'Arabī) ${ }^{3}$, po Arabską Komisję Praw Człowieka (Lağnat Huqūq al-Insān al-'Arabiyya) ustanowioną w 2008 r., po wejściu w życie Arabskiej Karty Praw Człowieka (Al-Mìtāq al-'Arabì li-Huqūq al-Insān $)^{4}$. Za największe zaś osiągnięcie działań arabskich na rzecz zapewnienia ochrony i promocji praw człowieka uznano wspomniany wyżej dokument, zredagowany i sygnowany - jak stanowi treść Preambuły - w celu potwierdzenia akceptacji i aprobaty Ligi Państw Arabskich i jej państw członkowskich dla zasad zawartych w Karcie Narodów Zjednoczonych, Powszechnej Deklaracji Praw Człowieka, Międzynarodowym Pakcie Praw Obywatelskich i Politycznych, Międzynarodowym Pakcie Praw Społecznych i Gospodarczych, Arabskiej Karcie Praw Człowieka i Kairskiej Deklaracji Praw Człowieka w Islamie ${ }^{5}$.

2 http://www.lasportal.org/ar/sectors/dep/HumanRightsDep/Pages/ Committee.aspx [dostęp: 20.07.2019].

3 http://www.lasportal.org/ar/Pages/default.aspx [dostęp: 20.07.2019].

4 http://www.lasportal.org/ar/humanrights/Committee/Pages/default. aspx [dostęp: 20.07.2019].

5 http://hrlibrary.umn.edu/arab/a004.html [dostęp: 20.07.2019]. 


\section{Arabska Karta Praw Człowieka (Al-Mītāa q al-'Arabì li-Ḥqūq al-Insān) - tłum. na język polski}

\section{Arabska Karta Praw Człowieka (Al-Mītāq al-'Arabì li-Ḥuqūq al-Insān) z 15 września 1994 r. ${ }^{6}$}

\section{PREAMBUŁA}

Rządy państw arabskich - członków Ligi Państw Arabskich, wychodząc od przekonania narodu arabskiego o ludzkiej godności, [które posiadł on] w chwili, gdy Bóg umocnił go, uczyniwszy świat arabski kolebką religii i miejscem narodzin cywilizacji, które potwierdziły jego prawo do godnego życia, opartego na wolności, sprawiedliwości i pokoju, zgodnie z odwiecznymi zasadami braterstwa i równości między wszystkimi istotami ludzkimi, które zostały ustanowione przez prawo muzułmańskie i inne religie objawione, będąc dumnymi z wartości i zasad humanitarnych, które ustanowiły one na kartach swojej długiej historii, a które odegrały ważną rolę w szerzeniu wiedzy przez centra naukowe pomiędzy Wschodem a Zachodem, tym samym czyniąc je celem, do którego zmierzali mieszkańcy globu i poszukujący wiedzy, kultury oraz mądrości i niech cały świat arabski od jednego najdalszego krańca po drugi woła jednym głosem, by zachować swoje przekonania, pokładając wiarę w swoją jedność, walcząc o ochronę swojej wolności, broniąc prawa narodów do samostanowienia i ochrony swojego dziedzictwa, wierząc w praworządność, by każdy człowiek mógł cieszyć się wolnością i sprawiedliwością, by równość szans była

6 Autorki dokonały przekładu bezpośrednio z języka arabskiego, tekst dostępny na stronie: http://hrlibrary.umn.edu/arab/a003.html [dostęp: 20.07.2019]. 
standardem każdego społeczeństwa, odrzucając rasizm i syjonizm, które stanowią łamanie praw człowieka i zagrożenie dla pokoju na świecie, potwierdzając ścisły związek między prawami człowieka a pokojem na świecie, potwierdzając zasady Karty Narodów Zjednoczonych ${ }^{7}$ i Powszechnej Deklaracji Praw Człowieka ${ }^{8}$ oraz postanowienia Międzynarodowych Paktów Organizacji Narodów Zjednoczonych ${ }^{9}$ Praw Obywatelskich

7 Karta Narodów Zjednoczonych (Charter of the United Nations), dokument o zasięgu globalnym i charakterze konstytucyjnym, jest najważniejszym aktem normatywnym Organizacji Narodów Zjednoczonych (United Nations). Została przyjęta na międzynarodowej konferencji w San Francisco 26 czerwca 1945 r. i podpisana przez członków pierwotnych, tj. 51 państw, w tym Polskę (16 października 1945 r.), weszła w życie w październiku tego samego roku. Inna nazwa dokumentu to Konstytucja ONZ (Constitution of the United Nations). Dokument, złożony z 19 rozdziałów i 111 artykułów, zawiera zasady działania ONZ, cele, kwestie członkostwa, opis głównych organów organizacji oraz ich kompetencje. Został spisany w pięciu językach: francuskim, hiszpańskim, rosyjskim, angielskim oraz chińskim. Wraz z innymi aktami, takimi jak Powszechna Deklaracja Praw Człowieka (Universal Declaration of Human Rights), stanowi uniwersalny system ochrony praw człowieka. Zgodnie z literą art. 103 dokumentu „w razie sprzeczności między zobowiązaniami członków Organizacji Narodów Zjednoczonych, wynikającymi z niniejszej Karty, a ich zobowiązaniami, wynikającymi z jakiekolwiek innej umowy międzynarodowej, zobowiązania wynikające z niniejszej Karty mają pierwszeństwo". Dokument w języku polskim dostępny na stronie: http://www.bb.po.gov.pl/Prawa/PNZ/KNZ.pdf [dostęp: 20.07.2019].

8 Powszechna Deklaracja Praw Człowieka (Universal Declaration of Human Rights, dalej: PDPC) stanowi najważniejszy międzynarodowy dokument w dziedzinie praw człowieka. Została wydana (wraz z postanowieniami o prawie petycji, losach mniejszości oraz o rozpowszechnianiu Deklaracji) przez Zgromadzenie Ogólne Narodów Zjednoczonych 10 grudnia $1948 \mathrm{r}$. w Paryżu. Akt ten jest jedną z trzech części tzw. Karty Praw (The Bill of Rights), na którą składają się - oprócz Deklaracji - dwa traktaty z 1966 r. - Pakt Praw Gospodarczych, Społecznych i Kulturalnych (Covenant on Economic, Social and Cultural Rights) oraz Pakt Praw Obywatelskich i Politycznych (Covenant on Civil and Political Rights). Art. 1 Powszechnej Deklaracji Praw Człowieka głosi, że „wszyscy ludzie rodzą się wolni i równi pod względem swej godności i swych praw. Są oni obdarzeni rozumem i sumieniem oraz powinni postępować w stosunku do siebie wzajemnie w duchu braterstwa". Dokument w języku polskim dostępny na stronie: http://www.bb.po.gov.pl/ Prawa/PNZ/PDPCZ.pdf [dostęp: 20.07.2019].

9 Są to dwie międzynarodowe umowy z dziedziny praw człowieka, wy- 


\section{i Politycznych ${ }^{10}$ i Praw Gospodarczych, Społecznych i Kultural- nych $^{11}$, a także Kairskiej Deklaracji Praw Człowieka w Islamie ${ }^{12}$.}

dane w 1966 r. w Nowym Jorku przez Zgromadzenie Ogólne ONZ. Obejmują problematykę praw człowieka i stanowią kontynuację oraz rozwinięcie sporządzonej w 1948 r. Powszechnej Deklaracji Praw Człowieka. Należą do nich dwa dokumenty: Międzynarodowy Pakt Praw Gospodarczych, Społecznych i Kulturalnych (Covenant on Economic, Social and Cultural Rights) oraz Międzynarodowy Pakt Praw Obywatelskich i Politycznych (Covenant on Civil and Political Rights).

10 Międzynarodowy Pakt Praw Obywatelskich i Politycznych (International Covenant on Civil and Political Rights, dalej: MPPOP) to trzeci podstawowy dokument, tworzący z Międzynarodowym Paktem Praw Gospodarczych, Społecznych i Kulturalnych oraz Powszechną Deklaracją Praw Człowieka tzw. Kartę Praw Człowieka. Pakt wydany został, wraz z Protokołami Fakultatywnymi, w Nowym Jorku 16 grudnia 1966 r. Drugi Protokół Fakultatywny dotyczący zniesienia kary śmierci dodano w 1989 r. Dokument składa się z 53 artykułów, sporządzony jest, podobnie jak pozostałe akty wydane przez Zgromadzenie Ogólne NZ w pięciu językach, tych państw, których członkowie zasiadali w Radzie Bezpieczeństwa. W Pakcie zapisane zostały tzw. prawa I generacji, nazywane inaczej „prawami fundamentalnymi", do których zalicza się: prawo do życia, prawo do zrzeszania się, bierne oraz czynne prawo wyborcze, prawo do wyrażania opinii, prawo do udziału w życiu publicznym, prawo do skarg na organy państwa, prawo do wolności osobistej, wolności wyznania, wolności myśli i sumienia, prawo do wolności od tortur, prawo do rzetelnego procesu sądowego, prawo do swobodnego przemieszczania się, prawo do osobowości prawnej oraz równość każdego wobec prawa. Dokument w języku polskim dostępny na stronie: http://www. bb.po.gov.pl/Prawa/PNZ/MPPOP.pdf [dostęp: 20.07.2019].

11 Międzynarodowy Pakt Praw Gospodarczych, Społecznych i Kulturalnych (International Covenant on Economic, Social and Cultural Rights, dalej: MPPGSK) jest to drugi podstawowy dokument, obok Powszechnej Deklaracji Praw Człowieka, o zasięgu globalnym. Przyjęty 16 grudnia 1966 r. przez Zgromadzenie Ogólne NZ w Nowym Jorku wszedł w życie w styczniu dziesięć lat później (Polska podpisała dokument w marcu 1977 r.). Dokument, złożony z 31 artykułów, sporządzony został w pięciu językach: angielskim, francuskim, rosyjskim, hiszpańskim i chińskim. W Pakcie zapisane zostały tzw. prawa II generacji, do których należą: prawo do pracy, prawo do świadczeń socjalnych, prawo do wynagrodzenia, prawo do wypoczyn$\mathrm{ku}$, prawo do ubezpieczeń zdrowotnych, prawo do ochrony zdrowia, prawo do uczestnictwa w życiu kulturalnym oraz prawo do edukacji. Dokument w języku polskim dostępny na stronie: http://www.bb.po.gov.pl/Prawa/PNZ/ MPPGSK.pdf [dostęp: 20.07.2019].

12 Kairska Deklaracja Praw Człowieka w Islamie (I'lān al-Qāhira hawla Huqūq al-Insān fì al-Islām) - dokument o zasięgu międzynarodowym 
Potwierdzając wszystko to, co powiedziano wyżej uzgodniono jak następuje:

\section{ROZDZIAŁ I}

Art. 1

a) Wszystkie narody mają prawo do samostanowienia ${ }^{13}$ i kontroli nad swoim bogactwem i zasobami naturalnymi ${ }^{14} \mathrm{i}-$ w oparciu o to - maja prawo do swobodnego wyboru swojego systemu politycznego i swobodnego dążenia do rozwoju gospodarczego, społecznego i kulturalnego ${ }^{1516}$.

b) Rasizm, syjonizm, okupacja i obca dominacja stanowią wyzwanie dla ludzkiej godności i fundamentalną przeszkodę na drodze realizacji podstawowych praw narodów. Obowiązkiem jest potępienie wszystkich praktyk tego rodzaju i podjęcie działań na rzecz ich wyeliminowania.

\section{ROZDZIAŁ II}

Art. 2

Każde państwo będące stroną niniejszej Karty zobowiązuje się do zapewnienia każdej jednostce obecnej na jego teryto-

podpisany 5 sierpnia 1990 r. w Kairze przez 45 państw zrzeszonych w Organizacji Konferencji Islamskiej (Munazzamat at-Táāwun al.Islāmī, Organisation of Islamic Cooperation). Akt, złożony z 25 artykułów, określa podstawy prawodawstwa w zakresie praw człowieka w państwach muzułmańskich, zgodnie z jego literą podstawą tychże praw jest szari'at. Dokument w języku angielskim dostępny na stronie: http://hrlibrary.umn.edu/instree/cairodeclaration.html [dostęp: 20.07.2019].

13 Por. art. 1 ust. 2 KNZ.

14 Por. art. 1 ust. 2 MPPOP; art. 1 ust. 2 MPPGSK.

15 Por. art. 1 ust. 3 KNZ

16 Por. art. 1 ust. 1 MPPOP; art. 1 MPPGSK. 
rium i podlegającej jego władzy wszystkich praw i wolności określonych w niniejszym dokumencie bez względu na rasę, kolor skóry, płeć, język, wyznanie, poglądy, pochodzenie narodowe lub społeczne, majątek, urodzenie i inny status ${ }^{17}$, a także bez dyskryminacji mężczyzn i kobiet $^{18}$.

Art. 3

a) Żadne z podstawowych praw człowieka ustanowionych lub istniejących w jakimkolwiek państwie będącym stroną niniejszej Karty nie może być ograniczone przez prawo, umowę bądź prawo zwyczajowe ${ }^{19}$. Nie jest także możliwe odstępowanie od nich z powodu braku zawarcia tychże praw w Karcie bądź zawarcia ich w mniejszym zakresie ${ }^{20}$.

b) Żadne państwo będące stroną niniejszej Karty nie może odstępować od swobód w niej zawartych, z których korzystają obywatele innego państwa, w którym swobody te uznane są w mniejszym zakresie.

\section{Art. 4}

a) Ograniczenia praw i wolności gwarantowanych literą niniejszej Karty mogą być wprowadzone wyłącznie na mocy prawa i gdy uznane zostaną za konieczne dla ochrony bezpieczeństwa narodowego, gospodarki narodowej, porządku publicznego, zdrowia publicznego lub moralności bądź praw i wolności innych osób ${ }^{21}$.

b) Państwa będące stroną niniejszej Karty mogą w przypadku sytuacji nadzwyczajnej zagrażającej życiu narodu podjąć środki

\footnotetext{
17 Por. art. 1 ust. 3 KNZ; art. 2 ust. 1 MPPOP; art. 2 ust. 1-2 MPPGSK.

18 Por. art. 3 MPPOP; art. 3 MPPGSK.

19 Por. art. 5 ust. 2 MPPOP; art. 4 MPPGSK.

20 Por. art. 2 ust. 2 MPPOP; art. 5 ust. 2 MPPGSK.

21 Por. art. 4 ust. 1 MPPOP.
} 
uchylające ich zobowiązania wynikające z niniejszej Karty, w zakresie koniecznym ze względu na wymogi sytuacji ${ }^{22}$.

c) Takie ograniczenia lub odstępstwa w żadnych okolicznościach nie obejmują praw i gwarancji dotyczących zakazu tortur, poniżającego traktowania, repatriacji, azylu politycznego, procesu, niedopuszczalności ponownego rozpoznania tego samego czynu oraz statusu prawnego przestępstw i kar ${ }^{23}$.

Art. 5

Każda jednostka ma prawo do życia, wolności i bezpieczeństwa osobistego. Prawo to podlega ochronie prawnej ${ }^{24}$.

Art. 6

Nie może być mowy o przestępstwie lub karach poza tymi przewidzianymi przez prawo. Nie będzie podlegać karze czyn poprzedzający wydanie przepisu prawa. Oskarżony będzie korzystać z późniejszych ustaleń, jeżeli będzie to zgodne z jego interesem ${ }^{25}$.

Art. 7

Oskarżonego uznaje się za niewinnego do czasu, kiedy jego wina zostanie udowodniona $\mathrm{w}$ trakcie zgodnego $\mathrm{z}$ prawem procesu, w którym uzyskał on gwarancje niezbędne do obrony $^{26}$.

Art. 8

Każdy ma prawo do wolności i bezpieczeństwa osobistego, nikt nie może być poddany arbitralnemu aresztowaniu, uwię-

\footnotetext{
22 Por. art. 4 ust. 1 MPPOP.

23 Por. art. 4 ust. 2 MPPOP.

24 Por. art. 3 PDPC; art. 6 PPOP.

25 Por. art. 11 ust. 2 PDPC; art. 15 ust. 1 MPPOP.

26 Por. art. 11 ust. 1 PDPC; art. 14 ust. 2 MPPOP.
} 
zieniu ani zatrzymaniu bez podstawy prawnej i bez postawienia go przed sądem ${ }^{27}$.

Art. 9

Wszyscy ludzie są równi wobec prawa i każdy na terytorium państwa ma zagwarantowane prawo do postępowania sądowego ${ }^{28}$.

Art. 10

Kara śmierci może być nałożona tylko w przypadkach najpoważniejszych przestępstw ${ }^{29}$, a każdy skazany na śmierć ma prawo ubiegania się o ułaskawienie bądź zmniejszenie wymiaru kary ${ }^{30}$.

Art. 11

W żadnym wypadku kara śmierci nie może być nałożona za przestępstwo polityczne.

Art. 12

Kara śmierci nie może być nałożona na osobę poniżej 18. roku życia, na kobietę ciężarną do czasu rozwiązania ani na karmiącą matkę w okresie dwóch lat od daty narodzin dziecka ${ }^{31}$.

Art. 13

a) Państwa będące stronami niniejszej Karty będą chronić każdą istotę ludzką na swoim terytorium przed poddawaniem jej torturom fizycznym lub psychicznym, bądź okrutnemu, poniżającemu lub nieludzkiemu traktowaniu ${ }^{32}$. Podejmą one

\footnotetext{
27 Por. art. 9 PDPC; art. 9 ust. 1 MPPOP.

28 Por. art. 7 PDPC; art. 14 ust. 1 MPPOP.

29 Por. art. 6 ust. 2 MPPOP.

30 Por. art. 6 ust. 4 MPPOP.

31 Por. art. 6 ust. 5 MPPOP.

32 Por. art. 7 MPPOP.
} 
skuteczne środki w celu zapobiegania takim czynom i uznają tego rodzaju praktyki lub uczestnictwo w nich za przestępstwo podlegające karze ${ }^{33}$.

b) Nikt nie może być poddawany eksperymentom medycznym lub naukowym bez wyrażenia na to zgody ${ }^{34}$.

Art. 14

Nie jest możliwe więzienie osoby, która okazała się niezdolna do spłaty długu lub zobowiązania cywilnego ${ }^{35}$.

Art. 15

Osoby skazane na karę pozbawienia wolności będą traktowane z godnością ${ }^{36}$.

Art. 16

Nikt nie może być sądzony dwukrotnie za to samo przestępstwo ${ }^{37}$. Każdy, przeciwko komu wszczęto takie postępowanie, ma prawo zakwestionować jego legalność i zażądać zwolnienia. Każdy, kto padł ofiarą bezprawnego aresztowania lub zatrzymania ma prawo do odszkodowania.

\section{Art. 17}

Prywatność jest chroniona prawem, a każde jej naruszenie uznawane jest za przestępstwo. Pojęcie prywatności obejmuje osobiste sprawy rodzinne, nienaruszalność miru domowego oraz poufność korespondencji i innych prywatnych środków komunikacji ${ }^{38}$.

\footnotetext{
33 Por. art. 5 PDPC.

34 Por. art. 7 PPOP.

35 Por. art. 11 MPPOP.

36 Por. art. 10 MPPOP.

37 Por. art. 14 ust. 7 MPPOP.

38 Por. art. 12 PDPC; art. 17 MPPOP.
} 
Art. 18

Każdy ma prawo do tego, by uznawano jego osobowość prawną ${ }^{39}$.

Art. 19

Ludzie są źródłem władzy i każdy pełnoletni obywatel ma prawo do udziału w życiu politycznym, z którego będzie korzystać zgodnie z prawem ${ }^{40}$.

Art. 20

Każda osoba mieszkająca na terenie państwa ma prawo do swobodnego przemieszczania się i swobody wyboru miejsca zamieszkania w dowolnej części tego terytorium, w granicach przewidzianych prawem ${ }^{41}$.

Art. 21

Nikt nie może być arbitralnie lub niezgodnie z prawem powstrzymany przed opuszczeniem jakiegokolwiek państwa arabskiego, w tym jego własnego. Nie jest możliwe zakazywanie mu lub zmuszanie go przebywania w jakiejkolwiek części jego kraju ${ }^{42}$.

Art. 22

Nikt nie może zostać wydalony ze swojego państwa ani nie może być pozbawiony możliwości powrotu do swojego kraju ${ }^{43}$.

Art. 23

Każdy obywatel ma prawo ubiegać się o azyl polityczny

\footnotetext{
39 Por. art. 6 PDPC; art. 16 MPPOP.

40 Por. art. 21 ust. 1 PDPC.

41 Por. art. 13 ust. 1 PDPC; art. 12 ust. 1 MPPOP.

42 Por. art. 13 ust. 2 PDPC; art. 12 ust. 2 MPPOP.

43 Por. art. 9 PDPC; art. 12 ust. 4 MPPOP.
} 
w innych państwach, aby uniknąć prześladowañ ${ }^{44}$. Prawo to nie przysługuje osobie ściganej za zwykłe przestępstwo w rozumieniu prawa powszechnego ${ }^{45}$. Uchodźcy polityczni nie podlegają ekstradycji.

Art. 24

Żaden obywatel nie może być arbitralnie pozbawiony swojego pierwotnego obywatelstwa, a jego prawo do nabycia innego obywatelstwa nie może zostać odrzucone bez uzasadnionej podstawy prawnej ${ }^{46}$.

Art. 25

Prawo własności prywatnej jest zagwarantowane każdemu obywatelowi ${ }^{47}$. Żaden obywatel nie może być w żadnym wypadku pozbawiony całości lub części jego majątku arbitralnie lub niezgodnie $\mathrm{z}$ prawem ${ }^{48}$.

Art. 26

Każdemu gwarantuje się wolność przekonań, myśli i opinii ${ }^{49}$.

Art. 27

Wyznawcy każdej religii mają prawo praktykowania swoich obrzędów religijnych oraz prawo do manifestacji swoich poglądów poprzez wiarę, praktykę lub naukę, nie naruszając praw innych osób ${ }^{50}$. Nie stosuje się ograniczeń w korzystaniu

\footnotetext{
44 Por. art. 14 ust. 1 PDPC.

45 Por. art. 14 ust. 2 PDPC.

46 Por. art. 15 ust. 2 PDPC

47 Por. art. 17 ust. 1 PDPC.

48 Por. art. 17 ust. 2 PDPC.

49 Por. art. 18 PDPC; art. 18 ust. 1 i art. 19 MPPOP.

50 Por. art. 19 PDPC; art. 18 ust. 1 MPPOP.
} 
z wolności przekonań, myśli i opinii, z wyjątkiem sytuacji przewidzianych prawem ${ }^{51}$.

Art. 28

Obywatele mają prawo do pokojowego zgromadzania się i stowarzyszania ${ }^{52}$. Nie stosuje się ograniczeń w korzystaniu z tego prawa, chyba że jest to konieczne z uwagi na wymogi bezpieczeństwa narodowego, bezpieczeństwa publicznego lub potrzebę ochrony praw i wolności innych osób ${ }^{53}$.

Art. 29

Państwo gwarantuje prawo do tworzenia związków zawodowych $^{54}$ i prawo do strajku w granicach przewidzianych prawem $^{55}$.

Art. 30

Państwo gwarantuje każdemu obywatelowi prawo do pracy, która zapewni mu poziom życia umożliwiający zaspokojenie podstawowych potrzeb życiowych ${ }^{56}$. Gwarantuje mu także prawo do pełnego zabezpieczenia społecznego ${ }^{57}$.

\section{Art. 31}

Gwarantowany jest swobodny wybór pracy ${ }^{58}$, a praca przymusowa jest zabroniona ${ }^{59}$. Wymierzenie kary wykonywania

51 Por. art. 18 ust. 3 MPPOP.

52 Por. art. 20 ust. 1 PDPC.

53 Por. art. 21 MPPOP.

54 Por. art. 23 ust. 4 PDPC; art. 22 ust. 1 MPPOP; art. 8 ust. 1a MPPGSK.

55 Por. art. 8 ust. 1d MPPGSK.

56 Por. art. 23 ust. 1 PDPC; art. 6 ust. 1 MPPGSK.

57 Por. art. 22 PDPC; art. 9 MPPGSK.

58 Por. art. 23 ust. 1 PDPC.

59 Por. art. 4 PDPC. 
pracy na podstawie wyroku sądowego nie jest uważane za pracę przymusową.

\section{Art. 32}

Państwo gwarantuje obywatelom równe szanse w zakresie dostępu do zatrudnienia, a także sprawiedliwego wynagrodzenia i równości płacy za pracę o równej wartości ${ }^{60}$.

Art. 33

Każdy obywatel ma prawo dostępu do urzędów publicznych w swoim kraju ${ }^{61}$.

\section{Art. 34}

Obowiązkiem jest zwalczanie analfabetyzmu, a każdy obywatel ma prawo do edukacji ${ }^{62}$. Kształcenie na poziomie co najmniej podstawowym jest obowiązkowe i bezpłatne, a kształcenie na poziomie średnim i uniwersyteckim powinno być ogólnie dostępne $\mathrm{e}^{63}$.

\section{Art. 35}

Obywatele mają prawo do życia w środowisku rozwiniętym intelektualnie i kulturowo, w którym arabski nacjonalizm jest źródłem dumy, w którym szanowane są prawa człowieka, a odrzuca się dyskryminacje rasowe, religijne i inne, w którym wspierane są współpraca międzynarodowa i pokój na świecie ${ }^{64}$.

\section{Art. 36}

Każdy ma prawo do uczestnictwa w życiu kulturalnym, a także prawo do korzystania z dzieł literackich i artystycz-

\footnotetext{
60 Por. art. 23 ust. 2 PDPC; art. 7a I MPPGSK

61 Por. art. 21 ust. 2 PDPC.

62 Por. art. 26 ust. 1 PDPC; art. 13 ust. 1 MPPGSK.

63 Por. art. 26 ust. 1 PDPC; art. 13 ust. 2a,b,c MPPGSK.

64 Por. art. 28 PDPC; art. 23 ust. 1 MPPOP.
} 
nych ${ }^{65}$ oraz zapewnione możliwości rozwoju swoich talentów artystycznych, intelektualnych i twórczych ${ }^{66}$.

Art. 37

Mniejszości nie będą pozbawione prawa do kultywowania swojej kultury bądź praktykowania zasad swojej wiary ${ }^{67}$.

Art. 38

a) Rodzina jest podstawową jednostką społeczną i zapewniona jest jej ochrona prawna ${ }^{68}$.

b) Państwo zobowiązuje się zapewnić szczególną opiekę i ochronę rodzinie, matkom, dzieciom i ludziom w podeszłym wieku ${ }^{69}$.

Art. 39

Młodzież ma prawo do uzyskania możliwie największych możliwości rozwoju fizycznego i psychicznego.

\section{ROZDZIAŁ III}

Art. 40

a) Członkowie Rady Ligi będący stronami niniejszej Karty wybierają w tajnym głosowaniu Komisję Ekspertów ds. Praw Człowieka.

b) Komisja składa się z siedmiu członków mianowanych przez państwa członkowskie będące stronami niniejszej Karty. Pierwsze wybory do Komisji odbędą się sześć miesięcy po

\footnotetext{
65 Por. art. 27 ust. 1 PDPC; art. 15 ust. 1a,b MPPGSK.

66 Por. art. 27 ust. 2 PDPC.

67 Por. art. 27 MPPOP.

68 Por. art. 16 ust. 3 PDPC; art. 10 ust. 1 MPPGSK.

69 Por. art. 25 ust. 2 PDPC; art. 10 ust. 2-3 MPPGSK.
} 
wejściu w życie Karty. W skład Komisji nie może wchodzić więcej niż jeden przedstawiciel danego państwa.

c) Sekretarz Generalny zwróci się do państw członkowskich o złożenie propozycji kandydatów na dwa miesiące przed planowaną datą wyborów.

d) Od kandydatów wymaga się, by posiadali szerokie doświadczenie i kompetencje w dziedzinie działalności Komisji. Eksperci będą pełnić swoje funkcje osobiście, z zachowaniem zasady uczciwości i bezstronności.

e) Członkowie Komisji są wybierani na trzyletnią kadencję, która w przypadku trzech z nich jest odnawialna na kolejną kadencję, ich nazwiska wybiera się w drodze losowania. W miarę możliwości należy przestrzegać zasad rotacji.

f) Komisja wybiera swojego przewodniczącego i opracowuje swój regulamin wewnętrzny.

g) Posiedzenia Komisji będą odbywać się w siedzibie Sekretariatu Generalnego Ligi na zaproszenie Sekretarza Generalnego. Za jego zgodą Komisja może odbyć posiedzenie w innym państwie arabskim, jeśli zajdzie taka potrzeba.

\section{Art. 41}

1. Państwa będące stronami niniejszej Karty przedłożą raporty Komisji Ekspertów ds. Praw Człowieka w następujący sposób:

a) Pierwszy raport po roku od daty wejścia Karty w życie.

b) Raporty okresowe co trzy lata.

c) Raporty zawierające odpowiedzi państwa na pytania Komisji.

2. Komisja rozpatruje raporty przedłożone przez państwa będące stronami niniejszej Karty zgodnie z ust. 1 niniejszego artykułu.

3. Komisja przedkłada Stałej Komisji ds. Praw Człowieka 
w Lidze Państw Arabskich raporty wraz z opiniami i uwagami państw.

\section{ROZDZIAŁ IV}

Art. 42

a) Sekretarz Generalny Ligi Państw Arabskich przedkłada niniejszą Kartę, po jej zatwierdzeniu przez Radę Ligi, państwom członkowskim do podpisu, ratyfikacji lub akcesji.

b) Niniejsza Karta wejdzie w życie po upływie dwóch miesięcy od daty złożenia siódmego dokumentu ratyfikacji lub akcesji w Sekretariacie Ligi Państw Arabskich.

Art. 43

Niniejsza Karta wchodzi w życie w każdym państwie w ciągu dwóch miesięcy od daty złożenia w Sekretariacie dokumentu ratyfikacyjnego lub akcesyjnego. Sekretarz Generalny powiadomi państwa członkowskie o złożeniu każdego dokumentu ratyfikacyjnego lub akcesyjnego.

\section{Arabska Karta Praw Człowieka (Al-Mītāq al-'Arabì li-Huqūq al-Insān) z 22 maja 2004 r. $^{70}$}

\section{PREAMBUŁA}

Wychodząc od przekonania narodu arabskiego o ludzkiej godności, [które posiadł on] w chwili, gdy Bóg umocnił go, uczyniwszy świat arabski kolebką religii i miejscem narodzin cywilizacji, które potwierdziły jego prawo do godnego życia,

70 Autorki dokonały przekładu bezpośrednio z języka arabskiego, tekst dostępny na stronie: http://hrlibrary.umn.edu/arab/a003-2.html [dostęp: 20.07.2019]. 
opartego na wolności, sprawiedliwości i równości, zgodnie z odwiecznymi zasadami braterstwa, równości i tolerancji między wszystkimi istotami ludzkimi, które zostały ustanowione przez prawo muzułmańskie i inne religie objawione, będąc dumnymi z wartości i zasad humanitarnych, które ustanowiły one na kartach swojej długiej historii, a które odegrały ważną rolę w szerzeniu wiedzy przez centra naukowe pomiędzy Wschodem a Zachodem, tym samym czyniąc je celem, do którego zmierzali mieszkańcy globu i poszukujący wiedzy, kultury oraz mądrości, pokładając wiarę w jedność narodu arabskiego, walcząc o ochronę swojej wolności, broniąc prawa narodów do samostanowienia i ochrony swojego dziedzictwa, wierząc w rządy prawa i jego rolę w ochronę praw człowieka w pełnym i kompleksowym rozumieniu tego słowa, w przekonaniu, że korzystanie przez człowieka z wolności, sprawiedliwości i równości szans jest podstawową miarą wartości każdego społeczeństwa, odrzucając wszelkie formy rasizmu i syjonizmu, które stanowią łamanie praw człowieka i zagrożenie dla międzynarodowego pokoju i bezpieczeństwa, uznając ścisły związek między prawami człowieka a międzynarodowym pokojem i bezpieczeństwem, potwierdzając zasady Karty Narodów Zjednoczonych ${ }^{71}$ i Powszechnej Deklaracji Praw Człowieka ${ }^{72}$ oraz postanowienia Międzynarodowych Paktów Organizacji Narodów Zjednoczonych Praw Obywatelskich i Politycznych ${ }^{73}$ i Praw Gospodarczych, Społecznych i Kulturalnych ${ }^{74}$, a także Kairskiej Deklaracji Praw Człowieka w Islamie ${ }^{75}$.

\footnotetext{
71 Karta Narodów Zjednoczonych - zob. przyp. 7.

72 Powszechna Deklaracja Praw Człowieka - zob. przyp. 8.

73 Międzynarodowy Pakt Praw Obywatelskich i Politycznych - zob. przyp. 10.

74. Międzynarodowy Pakt Praw Gospodarczych, Społecznych i Kulturalnych - zob. przyp. 11 .
}

75 Kairska Deklaracja Praw Człowieka w Islamie - zob. przyp. 12. 
W oparciu o to, co powiedziano wyżej, państwa będące stronami niniejszej Karty uzgodniły, jak następuje:

Art. 1

Niniejsza Karta ma na celu osiągnięcie następujących zamierzeń w ramach tożsamości narodowej państw arabskich i poczucia wspólnej przynależności kulturowej:

1. Włączenie [kwestii] praw człowieka w państwach arabskich do kluczowych problemów narodowych, by uczynić je wzniosłym ideałem i fundamentem kształtowania woli jednostki w państwach arabskich, co pozwoli jej piąć się w górę ku temu, co lepsze, zgodnie ze szlachetnymi wartościami ludzkimi.

2. Wychowanie jednostki w państwach arabskich w poszanowaniu tożsamości, lojalności wobec kraju, przywiązaniu do jego ziemi, historii i wspólnych interesów oraz zaszczepieniu w niej kultury ludzkiego braterstwa, tolerancji i otwartości na innych, zgodnie z uniwersalnymi zasadami i wartościami oraz tymi, które zostały zawarte w międzynarodowych paktach praw człowieka.

3. Przygotowanie nowych pokoleń w państwach arabskich do wolnego i odpowiedzialnego życia w solidarnym społeczeństwie obywatelskim, opartym na powiązaniu pomiędzy świadomością praw a poszanowaniem zobowiązań, w którym panują wartości [takie jak] równość, tolerancja i umiarkowanie.

4. Ustanowienie zasady, że wszystkie prawa człowieka są uniwersalne, niepodzielne, współzależne i powiązane.

Art. 2

1. Wszystkie narody mają prawo do samostanowienia i kontroli nad swoim bogactwem i zasobami naturalnymi oraz prawo do swobodnego wyboru swojego systemu politycznego i swobodnego dążenia do rozwoju ekonomicznego, społecz- 
nego i kulturalnego ${ }^{76}$.

2. Wszystkie narody mają prawo do narodowej suwerenności i integralności terytorialnej.

3. Wszelkie formy rasizmu, syjonizmu, okupacji i obcej dominacji stanowią wyzwanie dla ludzkiej godności i fundamentalną przeszkodę na drodze realizacji podstawowych praw narodów. Obowiązkiem jest potępienie wszystkich praktyk tego rodzaju i podjęcie działań na rzecz ich wyeliminowania.

4. Wszystkie narody mają prawo do oporu wobec obcej okupacji.

Art. 3

1. Każde państwo będące stroną niniejszej Karty zobowiązuje się do zapewnienia wszystkim jednostkom podlegającym jej jurysdykcji prawa do korzystania z praw i wolności określonych w niniejszym dokumencie, bez względu na rasę, kolor skóry, płeć, język, wyznanie, poglądy, pochodzenie narodowe lub społeczne, majątek, urodzenie lub niepełnosprawność fizyczną lub umysłową ${ }^{77}$.

2. Państwa będące stronami niniejszej Karty podejmą wszystkie niezbędne środki w celu zagwarantowania rzeczywistej równości w korzystaniu ze wszystkich praw i wolności określonych w niniejszej Karcie, w celu zapewnienia ochrony przed wszelkimi formami dyskryminacji ze względu na którąkolwiek z przyczyn wymienionych w poprzednim ustępie ${ }^{78}$.

3. Kobiety i mężczyźni są równi pod względem godności ludzkiej oraz praw i obowiązków w ramach pozytywnej dyskryminacji ustanowionej w interesie kobiety przez prawo muzułmańskie i inne religie objawione oraz obowiązujące prawa i instrumenty prawne. W związku z tym każde państwo będące

76 Por. art. 1 MPPOP; art. 1 ust. 1, art. 2 MPPGSK.

77 Por. art. 2 ust. 1 MPPOP; art. 2 ust. 2 MPPGSK.

78 Por. art. 2 ust. 2 MPPOP; art. 2 ust. 1 MPPGSK. 
stroną niniejszej Karty zobowiązuje się podjąć wszelkie niezbędne środki w celu zagwarantowania równych szans i faktycznej równości kobiet i mężczyzn w korzystaniu z wszelkich praw określonych w niniejszej Karcie ${ }^{79}$.

\section{Art. 4}

1. W wyjątkowych sytuacjach nadzwyczajnych, które zagrażają życiu narodu i zostały oficjalnie ogłoszone, państwa będące stronami niniejszej Karty mogą podjąć środki uchylające ich zobowiązania wynikające z niniejszej Karty, w zakresie ściśle określonym przez wymogi sytuacji, pod warunkiem, że takie środki nie są sprzeczne $\mathrm{z}$ ich innymi zobowiązaniami wynikającymi z prawa międzynarodowego i nie dotyczą dyskryminacji wyłącznie ze względu na rasę, kolor skóry, płeć, język, religię lub pochodzenie społeczne ${ }^{80}$.

2. W wyjątkowych sytuacjach nadzwyczajnych nie stosuje się żadnych odstępstw od następujących artykułów: art. 5, art. 8 , art. 9 , art. 10 , art. 13 , art. 14 par. 6 , art. 15 , art. 18 , art. 19, art. 20, art. 22, art. 27, art. 28, art. 29 i art. 30. Ponadto, gwarancje sądowe wymagane do ochrony wyżej wymienionych praw nie mogą zostać zawieszone ${ }^{81}$.

3. Każde państwo będące stroną niniejszej Karty posługujące się prawem do odstępstwa winno niezwłocznie powiadomić inne państwa-strony, za pośrednictwem Sekretarza Generalnego Ligi Państw Arabskich, o przepisach, od których odstąpiło oraz o powodach odstąpienia. Dalsze przekazywanie informacji odbywa się za pośrednictwem tego samego pośrednika w dniu, w którym kończy się takie odstępstwo ${ }^{82}$.

\footnotetext{
79 Por. art. 3 MPPOP; art. 3 MPPGSK.

80 Por. art. 4 ust. 1 MPPOP; art. 4 MPPGSK.

81 Por. art. 4 ust. 2 MPPOP.

82 Por. art. 4 ust. 3 MPPOP.
} 
Art. 5

1. Prawo do życia jest przyrodzonym prawem każdej jednostki ${ }^{83}$.

2. Prawo to podlega ochronie prawnej. Nikt nie może być w sposób dowolny pozbawiony życia ${ }^{84}$.

Art. 6

Kara śmierci może zostać nałożona tylko w przypadku najpoważniejszych przestępstw, zgodnie z prawem obowiązującym $\mathrm{w}$ chwili popełnienia przestępstwa i prawomocnym orzeczeniem wydanym przez właściwy sąd ${ }^{85}$. Każdy skazany na śmierć ma prawo ubiegania się o ułaskawienie bądź zmniejszenie wymiaru kary ${ }^{86}$.

Art. 7

1. Kara śmierci nie może być nałożona na osobę poniżej 18. roku życia, chyba że prawo obowiązujące w chwili popełnienia przestępstwa stanowi inaczej ${ }^{87}$.

2. Kara śmierci nie może być nałożona na kobietę ciężarną do czasu rozwiązania ani na matkę karmiącą w okresie dwóch lat od daty narodzin dziecka ${ }^{88}$. W każdym przypadku najważniejsze jest dobro dziecka.

Art. 8

1. Nikt nie może być poddany torturom fizycznym lub psychicznym ani okrutnemu, poniżającemu, upokarzającemu lub nieludzkiemu traktowaniu ${ }^{89}$.

\footnotetext{
83 Por. art. 3 PDPC; art. 6 ust. 1 MPPOP.

84 Por. art. 3 PDPC; art. 6 ust. 1 MPPOP.

85 Por. art. 6 ust. 2 MPPOP.

86 Por. art. 6 ust. 4 MPPOP.

87 Por. art. 6 ust. 5 MPPOP.

88 Por. art. 6 ust. 5 MPPOP.

89 Por. art. 5 PDPC; art. 7 MPPOP.
} 
2. Każde państwo będące stroną niniejszej Karty chroni jednostkę podlegającą jego jurysdykcji przed takimi praktykami oraz podejmuje skuteczne działania w celu ich zapobiegania. Podejmowanie takich działań lub udział w nich będzie uważane za przestępstwo podlegające karze, które nie podlega przedawnieniu. Każde państwo-strona zapewni w swoim systemie prawnym zadośćuczynienie dla ofiar tortur oraz prawo do rehabilitacji i odszkodowania.

Art. 9

Nikt nie może być poddawany eksperymentom medycznym lub naukowym ${ }^{90}$ ani wykorzystywaniu jego organów bez wyrażenia na to zgody i pełnej świadomości konsekwencji, z zachowaniem zasad etycznych, humanitarnych i zawodowych oraz przestrzeganiem procedur medycznych w celu zapewnienia bezpieczeństwa osobistego zgodnie z prawem obowiązującymi w każdym z państw-stron. Handel ludzkimi organami nie jest dopuszczalny w żadnych okolicznościach.

Art. 10

1. Wszelkie formy niewolnictwa i handlu ludźmi są zakazane i podlegają karze. Niewolnictwo i poddaństwo nie są dopuszczalne w żadnych okolicznościach ${ }^{91}$.

2. Praca przymusowa ${ }^{92}$, handel ludźmi w celu prostytucji lub wykorzystywania seksualnego, wykorzystywanie prostytucji innych osób lub jakiekolwiek inne formy wyzysku bądź wykorzystywania dzieci w konfliktach zbrojnych są zabronione.

\footnotetext{
90 Por. art. 7 MPPOP.

91 Por. art. 4 PDPC; art. 8 ust. 1-2 MPPOP.

92 Por. art. 8 ust. 3 MPPOP.
} 
Art. 11

Wszyscy ludzie są równi wobec prawa i mają prawo do korzystania z ochrony prawa bez jakiejkolwiek dyskryminacji ${ }^{93}$.

Art. 12

Wszyscy ludzie są równi przed sądami. Państwa będące stronami niniejszej Karty gwarantują niezawisłość sądownictwa i chronią sędziów przed wszelką ingerencją, presją lub groźbami. Gwarantują one również każdej osobie podlegającej ich jurysdykcji prawo do odwołania się do sądów wszystkich instancji ${ }^{94}$.

Art. 13

1. Każdy ma prawo do sprawiedliwego procesu, w czasie którego zapewnione zostaną odpowiednie gwarancje, przeprowadzanego przed kompetentnym, niezależnym i bezstronnym sądem ustanowionym z mocy prawa, w przypadku jakichkolwiek zarzutów karnych skierowanych przeciwko niemu lub orzeczeniach o jego prawach lub obowiązkach ${ }^{95}$. Każde państwo będące stroną niniejszej Karty gwarantuje tym, którzy nie posiadają wymaganych środków finansowych, pomoc prawną umożliwiającą im obronę swoich praw.

2. Procesy są jawne, z wyjątkiem sytuacji uzasadnionych interesem wymiaru sprawiedliwości w społeczeństwie, w którym szanuje się wolności i prawa człowieka.

Art. 14

1. Każdy ma prawo do wolności i bezpieczeństwa osobistego. Nikt nie może być poddany arbitralnemu aresztowaniu, uwięzieniu lub zatrzymaniu ${ }^{96}$.

\footnotetext{
93 Por. art. 7 PDPC; art. 26 MPPOP.

94 Por. art. 10 PDPC; art. 14 ust. 1 MPPOP.

95 Por. art. 10 PDPC; art. 14 ust. 1 MPPOP.

96 Por. art. 9 PDPC; art. 9 ust. 1 MPPOP.
} 
2. Nikt nie może być pozbawiony wolności, chyba że istnieją ku temu podstawy i okoliczności określone przez prawo i następuje to zgodnie z procedurami ustanowionymi literą prawa.

3. Osoba aresztowana jest informowana, w chwili zatrzymania, w języku, który rozumie, o przyczynach aresztowania oraz jest niezwłocznie informowana o wszelkich stawianych jej zarzutach $^{97}$. Ma ona prawo do kontaktu z rodziną.

4. Osoba pozbawiona wolności przez zatrzymanie lub aresztowanie ma prawo zażądać badania lekarskiego i zostanie o tym poinformowana.

5. Osoba aresztowana lub zatrzymana pod zarzutem przestępstwa zostaje niezwłocznie postawiona przed sędzią lub innym urzędnikiem uprawnionym ustawowo do wykonywania władzy sądowej. Podlega osądowi w rozsądnym terminie lub zwolnieniu. Może zostać zwolniona, jeśli aresztowanie lub zatrzymanie jest niezgodne z prawem ${ }^{98}$.

6. Osoba pozbawiona wolności przez zatrzymanie lub aresztowanie ma prawo do złożenia wniosku do właściwego sądu w celu niezwłocznego podjęcia decyzji o legalności zatrzymania lub aresztowania, i wydania nakazu zwolnienia, jeżeli zatrzymanie lub aresztowanie jest niezgodne z prawem ${ }^{99}$.

7. Każda osoba, która padła ofiarą dowolnego lub bezprawnego aresztowania lub zatrzymania ma prawo do odszkodowania ${ }^{100}$.

\section{Art. 15}

Nie może być mowy o przestępstwie lub karach poza tymi przewidzianymi przez prawo. We wszystkich okolicznościach stosuje się prawo najkorzystniejsze dla pozwanego ${ }^{101}$.

\footnotetext{
97 Por. art. 9 ust. 2 MPPOP.

98 Por. art. 9 ust. 3 MPPOP.

99 Por. art. 9 ust. 4 MPPOP.

100 Por. art. 9 ust. 5 MPPOP.

101 Por. art. 11 ust. 2 PDPC; art. 15 ust. 1 MPPOP.
} 
Art. 16

Oskarżonego uznaje się za niewinnego do czasu, kiedy jego wina zostanie udowodniona prawomocnym wyrokiem ${ }^{102}$, pod warunkiem że podczas dochodzenia i postępowania sądowego uzyskał on następujące gwarancje:

1. Prawo do natychmiastowej i szczegółowej informacji w języku, który rozumie, o postawionych mu zarzutach ${ }^{103}$.

2. Prawo do dysponowania odpowiednim czasem i środkami na przygotowanie obrony i pozwolenie na kontakt z rodziną ${ }^{104}$.

3. Prawo do postawienia przed sądem powszechnym oraz prawo do obrony ${ }^{105}$, osobiście lub przez ustanowionego osobiście obrońcę, z którym może kontaktować się w sposób swobodny z zachowaniem zasady poufności.

4. Prawo do korzystania z bezpłatnej pomocy obrońcy z urzędu, jeżeli nie może bronić się sam lub jeżeli wymaga tego interes wymiaru sprawiedliwości ${ }^{106}$, oraz prawo do korzystania z bezpłatnej pomocy tłumacza, jeżeli nie rozumie lub nie posługuje się językiem używanym w sądzie ${ }^{107}$.

5. Prawo do samodzielnego przesłuchania lub do przesłuchania przez ustanowionego obrońcę świadków oskarżenia oraz prawo do wezwania świadków na swoją obronę zgodnie z warunkami mającymi zastosowanie do świadków oskarżenia $^{108}$.

\footnotetext{
102 Por. art. 11 ust. 1 PDPC; art. 14 ust. 2 MPPOP.

103 Por. art. 14 ust. 3a MPPOP.

104 Por. art. 14 ust. 3b MPPOP.

105 Por. art. 14 ust. 3d MPPOP.

106 Por. art. 14 ust. 3d MPPOP.

107 Por. art. 14 ust. 3f MPPOP.

108 Por. art. 14 ust. 3e MPPOP.
} 
6. Prawo do odmowy składania zeznań przeciwko sobie lub do przyznania się do winy ${ }^{109}$.

7. Prawo do wniesienia apelacji do wyższej instancji, zgodnie $\mathrm{z}$ przepisami prawa, w przypadku skazania za przestępstwo ${ }^{110}$.

8. Prawo do poszanowania jego bezpieczeństwa osobistego i jego prywatności we wszystkich okolicznościach.

Art. 17

Każde państwo będące stroną niniejszej Karty zapewni w szczególności każdemu dziecku zagrożonemu przestępstwem lub oskarżonemu o popełnienie przestępstwa prawo dostępu do systemu wymiaru sprawiedliwości dla nieletnich, na każdym etapie dochodzenia, procesu i wykonania kary, a także prawo do specjalnego traktowania z uwzględnieniem jego wieku, ochrony jego godności, umożliwienia mu rehabilitacji, resocjalizacji i readaptacji społecznej ${ }^{111}$.

Art. 18

Nie jest możliwe więzienie osoby, która okazała się niezdolna do spłaty długu lub zobowiązania cywilnego ${ }^{112}$.

\section{Art. 19}

1. Nikt nie może być sądzony dwukrotnie za to samo przestępstwo $^{113}$. Każdy, przeciwko komu wszczęto takie postępowanie, ma prawo zakwestionować jego legalność i zażądać zwolnienia.

2. Każdy, kto został uniewinniony na mocy prawomocnego wyroku, ma prawo do odszkodowania za poniesioną szkodę ${ }^{114}$.

\footnotetext{
109 Por. art. 14 ust. 3g MPPOP.

110 Por. art. 14 ust. 5 MPPOP.

111 Por. art. 10 ust. 2b; art. 10 ust. 3; art. 14 ust. 4 MPPOP.

112 Por. art. 11 MPPOP.

113 Por. art. 14 ust. 7 MPPOP.

114 Por. art. 14 ust. 6 MPPOP.
} 
Art. 20

1. Wszystkie osoby pozbawione wolności będą traktowane z poszanowaniem ludzkiej godności ${ }^{115}$.

2. Oskarżeni są oddzieleni od skazanych i traktowani zgodnie ze statusem osób nieskazanych ${ }^{116}$.

3. Celem systemu penitencjarnego jest poprawa więźniów i ich społeczna readaptacja ${ }^{117}$.

\section{Art. 21}

1. Nikt nie może być arbitralnie lub niezgodnie z prawem poddawany ingerencji w jego prywatność, sprawy rodzinne i osobiste oraz korespondencję $e^{118}$, nikt nie może być arbitralnie lub bezprawnie pomawiany ${ }^{119}$.

2. Każdy ma prawo do prawnej ochrony przed takimi ingerencjami i pomówieniami ${ }^{120}$.

Art. 22

Każdy ma prawo do tego, by uznawano jego osobowość prawną $^{121}$.

Art. 23

Każde państwo będące stroną niniejszej Karty zobowiązuje się zapewnić osobie, której prawa lub wolności określone w niniejszym dokumencie zostały naruszone, skuteczne środki odwoławcze, nawet wówczas, gdy sprawcą naruszenia jest osoba pełniąca funkcje urzędowe.

\footnotetext{
115 Por. art. 10 ust. 1 MPPOP.

116 Por. art. 102 ust. 2 MPPOP.

117 Por. art. 10 ust., art. 16 MPPOP.

118 Por. art. 17 MPPOP.

119 Por. art. 12 PDPC; art. 17 MPPOP.

120 Por. art. 12 PDPC; art. 17 MPPOP.

121 Por. art. 6 PDPC.
} 
Art. 24

Każdy obywatel ma prawo do:

1. Wolności w działalności politycznej.

2. Udziału w zarządzaniu sprawami publicznymi, bezpośrednio lub poprzez swobodnie wybranych przedstawicieli ${ }^{122}$.

3. Biernego prawa wyborczego lub wyboru swoich reprezentantów w wolnych i bezstronnych wyborach, w warunkach równości wszystkich obywateli, gwarantujących swobodę wyrażania swojej woli ${ }^{123}$.

4. Możliwości uzyskania dostępu, na równi z innymi, do urzędów publicznych w swoim kraju zgodnie z zasadą równości szans ${ }^{124}$.

5. Swobodnego tworzenia z innymi stowarzyszeń i dołączenia do takich organizacji ${ }^{125}$.

6. Wolności zrzeszania się i pokojowego zgromadzania się $^{126}$.

7. Na korzystanie z tych praw nie można nakładać żadnych ograniczeń poza tymi, które są przewidziane przez prawo i konieczne w społeczeństwie, które szanuje prawa i wolności człowieka, w celu utrzymania bezpieczeństwa narodowego, porządku publicznego, bezpieczeństwa publicznego, zdrowia publicznego lub moralności oraz ochrony praw i wolności innych osób ${ }^{127}$.

\section{Art. 25}

Osobom należącym do mniejszości nie odmawia się prawa do kultywowania własnej kultury, używania własnego języka

\footnotetext{
122 Por. art. 21 ust. 1 PDPC; art. 25a MPPOP.

123 Por. art. 21 ust. 3 PDPC; art. 25b MPPOP.

124 Por. art. 21 ust. 2 PDPC; art. 25c 6 MPPOP.

125 Por. art. 20 ust. 1 PDPC; art. 22 ust. 1 MPPOP.

126 Por. art. 20 ust. 1 PDPC; art. 21 MPPOP.

127 Por. art. 21 MPPOP.
} 
i przestrzegania zasad swojej wiary. Przepisy prawa regulują korzystanie z tych praw ${ }^{128}$.

\section{Art. 26}

1. Każdy, kto legalnie przebywa na terytorium państwa będącego stroną niniejszej Karty, ma prawo do swobodnego przemieszczania się i wyboru miejsca zamieszkania w dowolnej części tego terytorium, zgodnie z obowiązującym prawem $^{129}$.

2. Żadne państwo będące strona niniejszej Karty nie może wydalić osoby, która nie posiada jego obywatelstwa, ale zgodnie z prawem przebywa na jej terytorium, w inny sposób niż na podstawie decyzji wydanej zgodnie z prawem i po umożliwieniu jej złożenia odwołania do właściwego organu, chyba że wymaga tego interes bezpieczeństwa narodowego. Zbiorowe wydalenie jest zabronione w każdych okolicznościach.

Art. 27

1. Nikt nie może być arbitralnie lub niezgodnie z prawem powstrzymany przed opuszczeniem jakiegokolwiek kraju, w tym jego własnego. Nie jest możliwe zakazywanie mu lub zmuszanie go przebywania w jakiejkolwiek części jego kraju ${ }^{130}$.

2. Nikt nie może zostać wydalony ze swojego kraju ani nie może być pozbawiony możliwości powrotu do swojego kraju ${ }^{131}$.

Art. 28

Każdy obywatel ma prawo ubiegać się o azyl polityczny w in-

\footnotetext{
128 Por. art. 27 MPPOP.

129 Por. art. 13 ust. 1 PDPC; art. 12 ust. 1 MPPOP.

130 Por. art. 13 ust. 2 PDPC; art. 12 ust. 2 MPPOP.

131 Por. art. 9 PDPC; art. 12 ust. 4 MPPOP.
} 
nych krajach, aby uniknąć prześladowań ${ }^{132}$. Prawo to nie przysługuje osobie ściganej za zwykłe przestępstwo w rozumieniu prawa powszechnego. Uchodźcy polityczni nie podlegają ekstradycji ${ }^{133}$.

Art. 29

1. Każdy ma prawo do obywatelstwa ${ }^{134}$. Nikt nie może być arbitralnie lub niezgodnie z prawem pozbawiony obywatelstwa ${ }^{135}$.

2. Państwa będące stronami niniejszej Karty podejmą środki, które uznają za stosowne i zgodne z obowiązującym regulacjami wewnętrznymi dotyczącymi obywatelstwa, by umożliwić dziecku nabycie obywatelstwa matki, z uwzględnieniem interesu dziecka we wszystkich przypadkach ${ }^{136}$.

3. Nikomu nie można odmówić prawa do nabycia innego obywatelstwa, z uwzględnieniem wewnętrznych procedur obowiązujących w jego kraju.

Art. 30

1. Każdy ma prawo do wolności myśli, sumienia i religii ${ }^{137}$. Nie można nakładać ograniczeń na korzystanie z tych wolności, z wyjątkiem przypadków przewidzianych obowiązującym prawem.

2. Swoboda manifestowania religii i przekonań oraz wolność praktykowania obrzędów religijnych ${ }^{138}$, samodzielnie lub we wspólnocie z innymi, podlega tylko takim ograniczeniom, jakie są określone przez prawo i konieczne w tolerancyjnym spo-

\footnotetext{
132 Por. art. 14 ust. 1 PDPC.

133 Por. art. 14 ust. 2 PDPC.

134 Por. art. 15 ust. 1 PDPC.

135 Por. art. 15 ust. 2 PDPC.

136 Por. art. 24 ust. 3 MPPOP.

137 Por. art. 18 PDPC; art. 18 ust. 1 MPPOP.

138 Por. art. 19 PDPC; art. 18 ust. 1 MPPOP.
} 
łeczeństwie, które szanuje prawa i wolności człowieka, w celu ochrony bezpieczeństwa publicznego, porządku publicznego, zdrowia publicznego lub moralności oraz ochrony podstawowych praw i wolności innych osób ${ }^{139}$.

3. Rodzice lub opiekunowie mają swobodę zapewnienia edukacji religijnej i moralnej swoich dzieci ${ }^{140}$.

\section{Art. 31}

Każdy ma zagwarantowane prawo do posiadania własności prywatnej ${ }^{141} \mathrm{i}$ nie może w żadnych okolicznościach zostać w sposób dowolny lub niezgodny z prawem pozbawiony części lub całości swojej własności ${ }^{142}$.

Art. 32

1. Niniejsza Karta gwarantuje prawo dostępu do informacji oraz do wolności słowa i opinii ${ }^{143}$, a także prawo do pozyskiwania i przekazywania informacji oraz idei w jakikolwiek sposób, niezależnie od geograficznych granic ${ }^{144}$.

2. Korzystanie z tych praw i wolności odbywa się w ramach podstawowych zasad społecznych i podlega jedynie takim ograniczeniom, jakie są konieczne dla zapewnienia poszanowania praw innych osób lub ochrony bezpieczeństwa narodowego, porządku publicznego, zdrowia publicznego lub moralności ${ }^{145}$.

Art. 33

1. Rodzina jest naturalną i podstawową jednostką społecz-

139 Por. art. 18 ust. 3 MPPOP.

140 Por. art. 18 ust. 4 MPPOP.

141 Por. art. 17 ust. 1 PDPC.

142 Por. art. 17 ust. 2 PDPC.

143 Por. art. 19 PDPC; art. 19 ust. 1-2 MPPOP.

144 Por. art. 19 PDPC; art. 19 ust. 2 MPPOP.

145 Por. art. 19 ust. 3 MPPOP. 
ną ${ }^{146}$, jej podstawą jest związek małżeński mężczyzny i kobiety. Mężczyźni i kobiety, którzy osiągnęli wymagany wiek, mają prawo do zawarcia związku małżeńskiego i założenia rodziny zgodnie z zasadami i warunkami małżeństwa ${ }^{147}$. Zawarcie związku małżeńskiego ma miejsce wyłącznie przy pełnej i dobrowolnej zgodzie obu stron ${ }^{148}$. Obowiązujące przepisy regulują prawa oraz obowiązki mężczyzny i kobiety w trakcie zawierania, trwania i rozwiązania związku małżeńskiego ${ }^{149}$.

2. Państwo i społeczeństwo zapewniają ochronę rodziny, wzmocnienie więzi rodzinnych, ochronę jej członków oraz zakaz wszelkich form przemocy lub wykorzystywania w relacjach między jej członkami, w szczególności w stosunku do kobiet i dzieci. Zapewniają niezbędną ochronę i opiekę matkom, dzieciom ${ }^{150}$, osobom w podeszłym wieku i tym ze szczególnymi potrzebami. Zapewniają młodzieży i ludziom młodym najlepsze możliwości rozwoju fizycznego i psychicznego ${ }^{151}$.

3. Państwa będące stronami niniejszej Karty zapewnią wszystkie niezbędne środki prawne, administracyjne i sądowe w celu zagwarantowania ochrony, przetrwania, rozwoju i dobrobytu dziecka w atmosferze wolności i godności ${ }^{152}$ oraz zapewniają, że we wszystkich przypadkach interes dziecka jest najważniejszym, podstawowym kryterium wszystkich podejmowanych w jego sprawie środków, nawet w sytuacji, gdy dopuszcza się wykroczenia lub przestępstwa.

\footnotetext{
146 Por. art. 16 ust. 3 PDPC; art. 23 ust. 1 MPPOP; art. 10 ust. 1 MPPGSK.

147 Por. art. 16 ust. 1 PDPC; art. 23 ust. 2 MPPOP.

148 Por. art. 16 ust. 2 PDPC; art. 23 ust. 3 MPPOP; art. 10 ust. 1 MPPGSK.

149 Por. art. 23 ust. 4 MPPOP.

150 Por. art. 25 ust. 2 PDPC; art. 10 ust. 1 MPPGSK; art. 10 ust. 2-3 MPPGSK.

151 Por. art. 10 ust. 3 MPPGSK.

152 Por. art. 24 ust. 1 MPPOP; art. 10 ust. 3 MPPGSK.
} 
4. Państwa będące stronami niniejszej Karty podejmą wszelkie niezbędne środki w celu zapewnienia, szczególnie młodym ludziom, prawa do uprawiania sportu.

\section{Art. 34}

1. Prawo do pracy jest przyrodzonym prawem każdego obywatela ${ }^{153}$. Państwo dołoży starań, aby zapewnić, w miarę możliwości, pracę dla jak największej liczby chętnych, zapewniając jednocześnie [warunki] produkcji, wolność wyboru zatrudnienia i równość szans, bez jakiejkolwiek dyskryminacji ze względu na rasę, kolor skóry, płeć, religię, język, poglądy polityczne, przynależność do związków zawodowych, obywatelstwo, pochodzenie społeczne, niepełnosprawność lub jakąkolwiek inną sytuację $e^{154}$.

2. Każdy pracownik ma prawo do korzystania ze sprawiedliwych i korzystnych warunków pracy, które zapewniają odpowiednie wynagrodzenie w celu zaspokojenia jego podstawowych potrzeb i potrzeb jego rodziny ${ }^{155}$ oraz regulują czasowy wymiar pracy, odpoczynku i płatnego urlopu ${ }^{156}$, a także zasady dotyczące ochrony bezpieczeństwa i higieny pracy ${ }^{157}$ oraz ochrony w miejscu pracy kobiet, dzieci i osób niepełnosprawnych.

3. Państwa będące stronami niniejszej Karty uznają prawo dziecka do ochrony przed wyzyskiem ekonomicznym i wykonywaniem pracy, która może być niebezpieczna, zakłócać edukację dziecka, szkodzić jego zdrowiu oraz fizycznemu, psychicznemu, duchowemu, moralnemu lub społecznemu rozwojowi ${ }^{158}$. W tym celu, mając na względzie odpowiednie posta-

\footnotetext{
153 Por. art. 23 ust. 1 PDPC; art. 6 ust. 1 MPPGSK.

154 Por. art. 23 ust. 2 PDPC; art. 6 ust. 2 MPPGSK.

155 Por. art. 23 ust. 3 PDPC; art. 7 MPPGSK.

156 Por. art. 24 PDPC; art. 7d MPPGSK.

157 Por. art. 7b MPPGSK.

158 Por. art. 10 ust. 3 MPPGSK.
} 
nowienia innych instrumentów międzynarodowych, państwa będące stronami niniejszej Karty, w szczególności powinny:

a) Określić minimalny wiek zatrudnienia ${ }^{159}$;

b) Ustanowić odpowiednie regulacje dotyczące wymiaru czasowego i warunków pracy ${ }^{160}$;

c) Nałożyć odpowiednie kary i inne sankcje w celu zapewnienia skutecznego egzekwowania tych przepisów ${ }^{161}$.

4. Niedopuszczalna jest dyskryminacja między mężczyznami a kobietami w korzystaniu z prawa do szkoleń, zatrudnienia, ochrony pracy i równego wynagrodzenia za tę samą pracę ${ }^{162}$.

5. Każde państwo będące stroną niniejszej Karty zapewni pracownikom migrującym na jego terytorium wymaganą ochronę zgodnie z obowiązującym prawem.

\section{Art. 35}

1. Każdy ma prawo swobodnego tworzenia stowarzyszeń i związków zawodowych oraz przystępowania do nich, a także swobodnego prowadzenia działalności związkowej w celu ochrony swoich interesów ${ }^{163}$.

2. Ograniczenia w korzystaniu z tych praw i wolności mogą być nałożone w oparciu o przepisy obowiązującego prawa i środki konieczne dla ochrony bezpieczeństwa narodowego, bezpieczeństwa publicznego, porządku publicznego, ochrony zdrowia publicznego oraz moralności, praw i wolności innych osób ${ }^{164}$.

\footnotetext{
159 Por. art. 10 ust. 3 MPPGSK.

160 Por. art. 10 ust. 3 MPPGSK.

161 Por. art. 10 ust. 3 MPPGSK.

162 Por. art. 7a I MPPGSK.

163 Por. art. 23 ust. 4 PDPC; art. 22 ust. 1 MPPOP; art. 8 ust. 1 MPPGSK.

164 Por. art. 22 ust. 2 MPPOP; art. 8 ust. 1c MPPGSK.
} 
3. Każde państwo będące stroną niniejszej Karty gwarantuje prawo do strajku w granicach przewidzianych przepisami prawa $^{165}$.

Art. 36

Państwa będące stronami niniejszej Karty gwarantują każdemu obywatelowi prawo do zabezpieczenia społecznego, w tym do ubezpieczenia społecznego ${ }^{166}$.

Art. 37

Prawo do rozwoju jest podstawowym prawem człowieka, a wszystkie państwa są zobowiązane do ustanowienia polityki rozwoju i środków koniecznych dla zagwarantowania tego prawa. Mają one obowiązek realizowania wartości solidarności i współpracy między nimi na szczeblu międzynarodowym w celu eliminacji ubóstwa i osiągnięcia rozwoju gospodarczego, społecznego, kulturalnego i politycznego. Na mocy tego prawa każdy obywatel ma prawo uczestniczyć w urzeczywistnianiu rozwoju i czerpać wypływające z niego korzyści ${ }^{167}$.

Art. 38

Każdy ma prawo do odpowiedniego poziomu życia dla siebie i swojej rodziny, zapewniającego dobrobyt i godne życie, w tym żywność, odzież, mieszkanie, usługi, a także prawo do życia w zdrowym środowisku ${ }^{168}$. Państwa będące stronami niniejszej Karty podejmą niezbędne środki, zgodnie ze swoimi możliwościami, w celu zagwarantowania realizacji tych praw.

\footnotetext{
165 Por. art. 8 ust. 1d MPPGSK.

166 Por. art. 22 PDPC; Aart. 9 MPPGSK.

167 Por. art. 22 PDPC; art. 11 ust. 1 MPPGSK.

168 Por. art. 25 ust. 1 PDPC.
} 
Art. 39

1. Państwa będące stronami niniejszej Karty uznają prawo każdej jednostki społecznej do korzystania z najwyższego możliwego do osiągnięcia poziomu zdrowia fizycznego i psychicznego ${ }^{169}$ oraz prawo obywatela do bezpłatnej podstawowej opieki zdrowotnej i dostępu do opieki medycznej bez jakiejkolwiek formy dyskryminacji.

2. Działania podjęte przez państwa będące stronami niniejszej Karty obejmują następujące środki:

a) Rozwój podstawowej opieki zdrowotnej i zapewnienie bezpłatnego i łatwego dostępu do ośrodków świadczących te usługi, niezależnie od położenia geograficznego i sytuacji ekonomicznej ${ }^{170}$.

b) Działania na rzecz profilaktyki w celu obniżenia poziomu śmiertelności ${ }^{171}$.

c) Promocję świadomości i edukacji zdrowotnej.

d) Zwalczanie tradycyjnych praktyk szkodliwych dla zdrowia jednostki.

e) Zapewnienie wszystkim podstawowej żywności i czystej wody pitnej.

f) Zwalczanie czynników [powodujących] zanieczyszczenia środowiska i zapewnienie odpowiednich systemów sanitarnych ${ }^{172}$.

g) Zwalczanie środków odurzających, substancji psychotropowych, wyrobów tytoniowych i substancji szkodliwych dla zdrowia.

\footnotetext{
169 Por. art. 12 ust. 1 MPPGSK.

170 Por. art. 12 ust. 2d MPPGSK.

171 Por. art. 12 ust. 2a MPPGSK.

172 Por. art. 12 ust. 2b MPPGSK.
} 
Art. 40

1. Państwa będące stronami niniejszej Karty zobowiązują się zapewnić osobom niepełnosprawnym umysłowo lub fizycznie godne życie, które zagwarantuje im godność, zwiększy ich samodzielność i ułatwi aktywne uczestnictwo w życiu społecznym.

2. Państwa będące stronami niniejszej Karty zapewnią bezpłatne usługi socjalne dla wszystkich osób niepełnosprawnych, zapewnią wsparcie materialne potrzebne tym osobom, ich rodzinom lub rodzinom opiekującym się nimi, a także zrobią wszystko, co konieczne dla unikania umieszczania tych osób w instytucjach opiekuńczych. We wszystkich przypadkach uwzględniają najlepszy interes osoby niepełnosprawnej.

3. Państwa będące stronami niniejszej Karty podejmą wszelkie niezbędne środki w celu ograniczenia występowania niepełnosprawności, wszelkimi możliwymi środkami, w tym profilaktycznymi programami zdrowotnymi, podnoszeniem świadomości i edukacją.

4. Państwa będące stronami niniejszej Karty zapewnią wszelkie usługi edukacyjne dostosowane do potrzeb osób niepełnosprawnych, biorąc pod uwagę znaczenie integracji tych osób w systemie edukacji, znaczenie kształcenia zawodowego i przyuczenia do zawodu oraz tworzenia miejsc pracy w sektorze publicznym lub prywatnym.

5. Państwa będące stronami niniejszej Karty zapewnią wszelkie odpowiednie usługi zdrowotne osobom niepełnosprawnych, w tym rehabilitację tych osób w celu integracji ze społeczeństwem.

6. Państwa będące stronami niniejszej Karty umożliwią osobom niepełnosprawnym korzystanie ze wszystkich publicznych i prywatnych obiektów usługowych. 


\section{Art. 41}

1. Obowiązkiem jest zwalczanie analfabetyzmu, a każdy obywatel ma prawo do edukacji ${ }^{173}$.

2. Państwa będące stronami niniejszej Karty zapewnią swoim obywatelom bezpłatną edukację przynajmniej na poziomie podstawowym. Edukacja na poziomie podstawowym będzie obowiązkowa i dostępna na wszystkich jej etapach i w każdym warunkach dla wszystkich, bez jakiejkolwiek dyskryminacji ${ }^{174}$.

3. Państwa będące stronami niniejszej Karty podejmą odpowiednie działania we wszystkich dziedzinach na rzecz zapewnienia partnerstwa między mężczyznami i kobietami dla urzeczywistnienia krajowych celów rozwoju.

4. Państwa będące stronami niniejszej Karty gwarantują zapewnienie edukacji ukierunkowanej na pełny rozwój osoby ludzkiej oraz promowanie poszanowania praw człowieka i podstawowych wolności ${ }^{175}$.

5. Państwa będące stronami niniejszej Karty dołożą starań, by włączyć zasady praw człowieka i podstawowych wolności do programów i działań edukacyjnych, programów wychowawczych, programów szkoleń i praktyk, rządowych i pozarządowych.

6. Państwa będące stronami niniejszej Karty gwarantują ustanowienie mechanizmów koniecznych do zapewnienia każdemu obywatelowi możliwości uczenia się przez całe życie i opracowanie krajowych planów kształcenia osób dorosłych.

Art. 42

1. Każdy ma prawo uczestniczenia w życiu kulturalnym i czerpania korzyści z postępu naukowego i jego zastosowań ${ }^{176}$.

\footnotetext{
173 Por. art. 26 ust. 1 PDPC; art. 13 ust. 1 MPPGSK.

174 Por. art. 26 ust. 1 PDPC; art. 13 ust. 2a MPPGSK.

175 Por. art. 26 ust. 2 PDPC; art. 13 ust. 1 MPPGSK.

176 Por. art. 27 ust. 1 PDPC; art. 15 ust. 1a, b MPPGSK.
} 
2. Państwa będące stronami niniejszej Karty zobowiązują się do poszanowania wolności badań naukowych i zapewnienia ochrony interesów moralnych i materialnych wynikających z twórczości naukowej, literackiej i artystycznej ${ }^{177}$.

3. Państwa będące stronami niniejszej Karty będą dążyć do współpracy i promowania współpracy na wszystkich płaszczyznach, przy pełnym udziale intelektualistów i twórców oraz ich organizacji, w celu opracowania i realizacji programów praktycznych, rekreacyjnych, kulturalnych, artystycznych i naukowych.

Art. 43

Niniejsza Karta nie może być odbierana ani interpretowana jako odstępstwo od praw i wolności chronionych przez ustawodawstwo wewnętrzne państw będących jej stronami lub praw określonych w międzynarodowych i regionalnych kartach praw człowieka, które państwa strony przyjęły lub ratyfikowały, w tym praw kobiet, dzieci i osób należących do mniejszości ${ }^{178}$.

\section{Art. 44}

Państwa będące stronami niniejszej Karty zobowiązują się do podjęcia, zgodnie z ich procedurami konstytucyjnymi i postanowieniami niniejszej Karty, wszelkich środków prawnych i innych koniecznych dla zapewnienia egzekwowania praw w niej określonych ${ }^{179}$.

Art. 45

1. Na mocy niniejszej Karty ustanawia się komisję nazwaną „Arabską Komisją Praw Człowieka”, zwaną dalej „Komisją”, zło-

\footnotetext{
177 Por. art. 26 ust. 2 PDPC; art. 15 ust. 1c MPPGSK.

178 Por. Aart. 5 PPOP; art. 15 ust. 2-4 MPPGSK.

179 Por. art. 28 PDPC; art. 2 ust. 2 MPPOP.
} 
żoną z siedmiu członków wybieranych w tajnym głosowaniu przez państwa będące stronami niniejszej Karty.

2. Komisja składa się z obywateli państw będących stronami niniejszej Karty. Kandydaci na członków Komisji winni posiadać szerokie doświadczenie i kompetencje w dziedzinie działalności Komisji. Członkowie Komisji będą pełnić swoje funkcje osobiście, z zachowaniem zasady uczciwości i bezstronności.

3. W skład Komisji wchodzi nie więcej niż jeden obywatel państwa-strony. Może zostać ponownie wybrany tylko raz. Przestrzega się zasady rotacji.

4. Członkowie Komisji są wybierani na czteroletnią kadencję, chociaż mandat trzech członków wybranych podczas pierwszych wyborów wynosi dwa lata i jest odnawiany w drodze losowania.

5. Sześć miesięcy przed datą wyborów Sekretarz Generalny Ligi Państw Arabskich zwraca się do państw będących stronami niniejszej Karty o zgłaszanie swoich kandydatów. Przekazuje on listę kandydatów państwom-stronom dwa miesiące przed datą wyborów. Kandydaci, którzy uzyskają największą liczbę głosów, zostaną wybrani do składu Komisji. Jeśli dwóch lub więcej kandydatów ma taką samą liczbę głosów, a liczba kandydatów o największej liczbie głosów przewyższa wymaganą liczbę, drugie głosowanie odbędzie się pomiędzy osobami o równej liczbie głosów. Jeżeli liczba głosów jest ponownie równa, członek lub członkowie wybierani są w drodze losowania. Pierwsze wybory do Komisji odbędą się nie później niż sześć miesięcy po wejściu w życie Karty.

6. Sekretarz Generalny zwołuje państwa będące stronami niniejszej Karty na spotkanie wyborcze członków Komisji, które odbywa się w siedzibie Ligi Państw Arabskich. Wymagane kworum stanowi zwykła większość państw-stron. Jeśli kworum nie zostanie osiągnięte Sekretarz Generalny zwołuje 
kolejne posiedzenie, które odbędzie się przy wymaganej obecności przynajmniej dwóch trzech państw-stron. Jeżeli nadal nie osiągnięto kworum, Sekretarz Generalny zwołuje trzecie posiedzenie, które odbędzie się bez względu na liczbę obecnych państw-stron.

7. Sekretarz Generalny zwołuje pierwsze posiedzenie Komisji, podczas którego następuje wybór przewodniczącego spośród jej członków, na dwuletnią kadencję, która może zostać jednokrotnie przedłużona na okres 2 lat. Komisja ustala regulamin wewnętrzny oraz sposób i częstotliwość posiedzeń. Komisja odbywa posiedzenia w siedzibie Ligi Państw Arabskich. Może odbyć posiedzenie w dowolnym państwie będącym stroną niniejszej Karty na zaproszenie tego państwa.

Art. 46

1. Sekretarz Generalny ogłasza wakat [w Komisji] po otrzymaniu zawiadomienia od jej przewodniczącego w następujących przypadkach:
a) Śmierć;
b) Rezygnacja;
c) Jeżeli członek Komisji, w jednomyślnej opinii pozostałych członków, zaprzestał pełnienia swojej funkcji bez podania możliwego do przyjęcia uzasadnienia lub z innego powodu niż czasowa nieobecność.

2. Jeżeli wakat na stanowisko członka zostanie ogłoszony zgodnie z przepisami ust. 1, a kadencja członka, który ma zostać zastąpiony, nie wygasa w ciągu sześciu miesięcy od daty ogłoszenia wakatu, Sekretarz Generalny Ligi Państw Arabskich przekaże sprawę państwom będącym stronami niniejszej Karty. Mogą one, w terminie dwóch miesięcy, przedstawić swoich kandydatów, zgodnie z art. 45, w celu obsadzenia wakatu.

3. Sekretarz Generalny Ligi Państw Arabskich sporządzi listę wszystkich zgłoszonych w odpowiedni sposób kandy- 
datów, w porządku alfabetycznym. Lista zostanie przekazana państwom będącym stronami niniejszej Karty. Wybory w celu obsadzenia wakatu przeprowadza się zgodnie z odpowiednimi przepisami.

4. Każdy członek Komisji wybrany do obsadzenia wakatu zgodnie z postanowieniami ust. 1 pozostaje członkiem Komisji do czasu wygaśnięcia pozostałej części kadencji członka, którego mandat został ogłoszony jako wolny, zgodnie z postanowieniami tego punktu.

5. Sekretarz Generalny Ligi Państw Arabskich zapewni w budżecie Ligi Państw Arabskich zasoby finansowe, personel i udogodnienia niezbędne dla skutecznego funkcjonowania Komisji. W kwestii wynagrodzenia i zwrotu poniesionych kosztów eksperci Komisji traktowani są na równi z ekspertami Sekretariatu Ligi Państw Arabskich.

\section{Art. 47}

Państwa będące stronami niniejszej Karty zobowiązują się do zapewnienia członkom Komisji wymaganych immunitetów koniecznych do ich ochrony przed jakąkolwiek formą nękania, presji moralnej lub materialnej, bądź jakichkolwiek konsekwencji sądowych ze względu na stanowiska lub oświadczenia, które zajęli czy wygłosili w trakcie wykonywania swoich obowiązków jako członkowie Komisji.

Art. 48

1. Państwa będące stronami niniejszej Karty zobowiązują się do przedkładania Sekretarzowi Generalnemu Ligi Państw Arabskich raportów dotyczących środków podjętych w celu realizacji praw i wolności określonych w niniejszej Karcie oraz postępów poczynionych w kwestii korzystania z tychże praw i wolności. Po otrzymaniu raportów Sekretarz Generalny przekazuje je do rozpatrzenia Komisji. 
2. Każde państwo będące stroną niniejszej Karty przedkłada Komisji wstępny raport w ciągu jednego roku od daty wejścia Karty w życie, następnie co trzy lata składa raport okresowy. Komisja może zwrócić się do państw-stron o przekazanie dodatkowych informacji dotyczących implementacji założeń Karty.

3. Komisja rozpatruje raporty złożone przez państwa będące stronami niniejszej Karty zgodnie z ust. 2, w obecności przedstawiciela państwa-strony, w celu omówienia raportu.

4. Komisja omawia raport, przedstawia swoje uwagi i wydaje rekomendacje zgodnie z celami Karty.

5. Komisja przekazuje sprawozdanie roczne zawierające jej uwagi i rekomendacje Radzie Ligi za pośrednictwem Sekretarza Generalnego.

6. Sprawozdania Komisji, uwagi końcowe i rekomendacje mają status dokumentów publicznych. Komisja podejmuje działania na rzecz ich rozpowszechnienia.

Art. 49

1. Sekretarz Generalny Ligi Państw Arabskich przedkłada niniejszą Kartę, po jej zatwierdzeniu przez Radę Ligi, państwom członkowskim do podpisu, ratyfikacji lub akcesji.

2. Niniejsza Karta wejdzie w życie po upływie dwóch miesięcy od daty złożenia siódmego dokumentu ratyfikacji lub akcesji w Sekretariacie Ligi Państw Arabskich.

3. Niniejsza Karta wchodzi w życie w każdym państwie w ciągu dwóch miesięcy od daty złożenia w Sekretariacie dokumentu ratyfikacyjnego lub akcesyjnego.

4. Sekretarz Generalny powiadomi państwa członkowskie o złożeniu każdego dokumentu ratyfikacyjnego lub akcesyjnego. 
Art. 50

Każde państwo będące stroną niniejszej Karty może przedłożyć, za pośrednictwem Sekretarza Generalnego, pisemne propozycje dotyczące poprawek niniejszej Karty. Po przekazaniu ich państwom członkowskim Sekretarz Generalny wzywa państwa będące stronami niniejszej Karty do dokonania wglądu w propozycje poprawek dokumentu, by zostały zatwierdzone przed przedłożeniem ich Radzie Ligi do przyjęcia.

\section{Art. 51}

Poprawki wchodzą w życie dla państw będących stronami niniejszej Karty, które je zatwierdziły, po ich ratyfikacji przez dwie trzecie państw-stron.

\section{Art. 52}

Każde państwo będące stroną niniejszej Karty może wysunąć propozycję protokołów dodatkowych do niniejszej Karty. Procedura ich przyjęcia jest taka, jaka obowiązuje w przypadku poprawek do Karty.

Art. 53

1. Podpisując niniejszą Kartę lub składając dokument ratyfikacyjny bądź akcesyjny każde państwo może zgłosić zastrzeżenie do dowolnego artykułu Karty, pod warunkiem, że takie zastrzeżenie nie jest sprzeczne z celami i podstawowymi założeniami Karty.

2. Każde państwo będące stroną niniejszej Karty, które zgłosiło zastrzeżenie zgodnie z ust. 1 niniejszego artykułu może je wycofać w każdej chwili, kierując zawiadomienie do Sekretarza Generalnego Ligi Państw Arabskich.

3. Sekretarz Generalny powiadamia państwa członkowskie o zgłoszonych zastrzeżeniach i wnioskach o ich wycofanie. 


\section{Arabska Karta Praw Czlowieka - analiza porównawcza pierwszej i drugiej wersji dokumentu}

Przechodząc do porównania obu wersji Arabskiej Karty Praw Człowieka (Al-Mìtāq al-'Arabì li-Huqūq al-Insān), należy przede wszystkim zaznaczyć, że obecnie obowiązujący dokument jest zrewidowaną wersją aktu z $1994 \mathrm{r}$.

Co się tyczy strony formalnej, to jest struktury dokumentów, pierwszy z nich podzielony został na rozdziały, artykuły oraz ustępy, natomiast w drugim znajdują się wyłącznie artykuły i ustępy.

W zawartości treściowej trudno byłoby wskazać istotne różnice, druga wersja Karty jest jednak znacznie bardziej dokładna, a poszczególne zasady i normy dotyczące praw człowieka zostały w niej bardziej szczegółowo opisane i/lub doprecyzowane. I tak, dla przykładu, dokument z 1994 r. stanowi jedynie, że „rodzina jest podstawową jednostką społeczną i zapewniona jest jej ochrona prawna”, a „państwo zobowiązuje się zapewnić szczególną opiekę i ochronę rodzinie, matkom, dzieciom i ludziom w podeszłym wieku" (art. 38). Natomiast w akcie z $2004 \mathrm{r}$. obecna jest rozszerzona wersja tych norm, bowiem zgodnie z jego litera „rodzina jest naturalną i podstawową jednostką społeczną, jej podstawą jest związek małżeński mężczyzny i kobiety. Mężczyźni i kobiety, którzy osiągnęli wymagany wiek, mają prawo do zawarcia związku małżeńskiego i założenia rodziny zgodnie z zasadami i warunkami małżeństwa. Zawarcie związku małżeńskiego ma miejsce wyłącznie przy pełnej i dobrowolnej zgodzie obu stron. Obowiązujące przepisy regulują prawa i obowiązki mężczyzny i kobiety w trakcie zawierania, trwania i rozwiązania związku małżeńskiego (art. 33 ust. 1), zaś „państwo i społeczeństwo 
zapewniają ochronę rodziny, wzmocnienie więzi rodzinnych, ochronę jej członków oraz zakaz wszelkich form przemocy lub wykorzystywania w relacjach między jej członkami, w szczególności w stosunku do kobiet i dzieci. Zapewniają niezbędną ochronę i opiekę matkom, dzieciom, osobom w podeszłym wieku i tym ze szczególnymi potrzebami. Zapewniają młodzieży i ludziom młodym najlepsze możliwości rozwoju fizycznego i psychicznego (art. 33 ust. 2).

Przede wszystkim obie wersje Arabskiej Karty Praw Człowieka (Al-Mītāãq al-'Arabì li-Huqūq al-Insān) zawierają najistotniejsze z punktu widzenia tej problematyki zasady i normy, takie jak:

- prawo narodów do samostanowienia (art. 1 Karty I i art. 2 Karty II);

- prawo do korzystania z praw i wolności bez względu na rasę, kolor skóry, płeć, język, wyznanie, poglądy, pochodzenie narodowe lub społeczne, majątek, urodzenie i inny status, a także bez dyskryminacji mężczyzn i kobiet (art. 2, art. 9 Karty I i art. 3, art. 11 Karty II);

- prawo do życia, wolności i bezpieczeństwa osobistego (art. 5, art. 8 Karty I i art. 5, art. 14 Karty II);

- prawo do prywatności (art. 17 Karty I i art. 21 Karty II);

- prawo własności prywatnej i majątku (art. 25 Karty I i art. 31 Karty II);

- prawo do wolności przekonań, myśli i opinii (art. 26 Karty I i art. 30 Karty II);

- prawo do praktykowania swojej religii (art. 27 Karty I i art. 30 Karty II);

- prawo do edukacji (art. 34 Karty I i art. 41 Karty II);

- prawo do udziału w życiu politycznym i dostępu do urzędów publicznych (art. 19, art. 33 Karty I i art. 24 Karty II); 
- prawo do pokojowego zgromadzania się i stowarzyszania (art. 28, art. 29 Karty I i art. 24, art. 35 Karty II);

- prawo do pracy i sprawiedliwego wynagrodzenia oraz zakaz pracy przymusowej (art. 30, art. 31, art. 32 Karty I i art. 34 Karty II);

- prawo do swobodnego przemieszczania się, pobytu w swoim kraju i obywatelstwa swojego kraju (art. 20, art. 21, art. 22, art. 24 Karty I i art. 26, Art. 27, art. 29 Karty II);

- prawo do sprawiedliwego procesu i prawa wobec wymiaru sprawiedliwości (art. 8, art. 15, art. 16 Karty I i art. 12, art. 13, art. 14 , art. 16, art. 19, art. 20 Karty II);

- prawo do azylu politycznego (art. 23 Karty I i art. 28 Karty II);

- prawa mniejszości do kultywowania swojej kultury i praktykowania zasad swojej wiary (art. 37 Karty I i art. 25 Karty II);

- zakaz tortur, okrutnego traktowania i eksperymentów medycznych (art. 13 Karty I i art. 8, art. 9 Karty II),

- zasady ograniczenia praw i wolności (art. 4 Karty I i art. 4 Karty II);

- zasady dotyczące kary śmierci (art. 10, art. 11, art. 12 Karty I i art. 6, art. 7 Karty II).

Zapisy, które można wskazać w dokumencie z 2004 r., a które nie są obecne w pierwszej wersji Karty to:

- „Każde Państwo będące stroną niniejszej Karty zobowiązuje się zapewnić osobie, której prawa lub wolności określone w niniejszym dokumencie zostały naruszone, skuteczne środki odwoławcze, nawet wówczas, gdy sprawcą naruszenia jest osoba pełniąca funkcje urzędowe" (art. 23);

- „Niniejsza Karta gwarantuje prawo dostępu do informacji oraz do wolności słowa i opinii, a także prawo do 
pozyskiwania i przekazywania informacji i idei w jakikolwiek sposób, niezależnie od geograficznych granic" (art. 32);

- „Państwa będące stronami niniejszej Karty zobowiązują się do poszanowania wolności badań naukowych i zapewnienia ochrony interesów moralnych i materialnych wynikających z twórczości naukowej, literackiej i artystycznej. Państwa będące stronami niniejszej Karty będą dążyć do współpracy i promowania współpracy na wszystkich płaszczyznach, przy pełnym udziale intelektualistów i twórców oraz ich organizacji, w celu opracowania i realizacji programów praktycznych, rekreacyjnych, kulturalnych, artystycznych i naukowych" (art. 42). Ponadto, w sposób bardziej szczegółowy, aktualna wersja Karty podejmuje zagadnienia dotyczące dzieci i młodzieży:

- w odniesieniu do ochrony i wychowania dziecka: „Państwa będące stronami niniejszej Karty zapewnią wszystkie niezbędne środki prawne, administracyjne i sądowe w celu zagwarantowania ochrony, przetrwania, rozwoju i dobrobytu dziecka w atmosferze wolności i godności oraz zapewniają, że we wszystkich przypadkach interes dziecka jest najważniejszym, podstawowym kryterium wszystkich podejmowanych w jego sprawie środków, nawet w sytuacji, gdy dopuszcza się wykroczenia lub przestępstwa" (art. 33 ust. 3);

- w odniesieniu do wymiaru sprawiedliwości: „Każde państwo będące stroną niniejszej Karty zapewni w szczególności każdemu dziecku zagrożonemu przestępstwem lub oskarżonemu o popełnienie przestępstwa prawo dostępu do systemu wymiaru sprawiedliwości dla nieletnich, na każdym etapie dochodzenia, procesu i wykonania kary, a także prawo do specjalnego traktowania $\mathrm{z}$ uwzględnieniem jego wieku, ochrony jego godności, umożliwienia 
mu rehabilitacji, resocjalizacji i readaptacji społecznej” (art. 17);

- w odniesieniu do pracy zarobkowej dzieci: „Państwa będące stronami niniejszej Karty uznają prawo dziecka do ochrony przed wyzyskiem ekonomicznym i wykonywaniem pracy, która może być niebezpieczna, zakłócać edukację dziecka, szkodzić jego zdrowiu oraz fizycznemu, psychicznemu, duchowemu, moralnemu lub społecznemu rozwojowi. W tym celu, mając na względzie odpowiednie postanowienia innych instrumentów międzynarodowych, państwa będące stronami niniejszej Karty, w szczególności powinny:

a) określić minimalny wiek zatrudnienia;

b) ustanowić odpowiednie regulacje dotyczące wymiaru czasowego i warunków pracy;

c) nałożyć odpowiednie kary i inne sankcje w celu zapewnienia skutecznego egzekwowania tych przepisów" (art. 34 ust. 3).

Znacznie większą wagę przykłada także aktualny dokument do prawa człowieka do rozwoju i dobrobytu, a co za tym idzie - zapewnienia mu możliwie najlepszych warunków życia i rozwoju:

- „Prawo do rozwoju jest podstawowym prawem człowieka, a wszystkie państwa są zobowiązane do ustanowienia polityki rozwoju i środków koniecznych dla zagwarantowania tego prawa. Mają one obowiązek realizowania wartości solidarności i współpracy między nimi na szczeblu międzynarodowym w celu eliminacji ubóstwa i osiągnięcia rozwoju gospodarczego, społecznego, kulturalnego i politycznego. Na mocy tego prawa każdy obywatel ma prawo uczestniczyć w urzeczywistnianiu rozwoju i czerpać wypływające z niego korzyści” (art. 37); 
- „Każdy ma prawo do odpowiedniego poziomu życia dla siebie i swojej rodziny, zapewniającego dobrobyt i godne życie, w tym żywność, odzież, mieszkanie, usługi, a także prawo dożycia w zdrowym środowisku. Państwa będące stronami niniejszej Karty podejmą niezbędne środki, zgodnie ze swoimi możliwościami, w celu zagwarantowania realizacji tych praw" (art. 38);

- „1. Państwa będące stronami niniejszej Karty uznają prawo każdej jednostki społecznej do korzystania z najwyższego możliwego do osiągnięcia poziomu zdrowia fizycznego i psychicznego oraz prawo obywatela do bezpłatnej podstawowej opieki zdrowotnej i dostępu do opieki medycznej bez jakiejkolwiek formy dyskryminacji.

2. Działania podjęte przez Państwa będące stronami niniejszej Karty obejmują następujące środki:

a) Rozwój podstawowej opieki zdrowotnej i zapewnienie bezpłatnego i łatwego dostępu do ośrodków świadczących te usługi, niezależnie od położenia geograficznego i sytuacji ekonomicznej.

b) Działania na rzecz profilaktyki w celu obniżenia poziomu śmiertelności.

c) Promocja świadomości i edukacji zdrowotnej.

d) Zwalczanie tradycyjnych praktyk szkodliwych dla zdrowia jednostki.

e) Zapewnienie wszystkim podstawowej żywności i czystej wody pitnej.

f) Zwalczanie czynników [powodujących] zanieczyszczenia środowiska i zapewnienie odpowiednich systemów sanitarnych.

g) Zwalczanie środków odurzających, substancji psychotropowych, wyrobów tytoniowych i substancji szkodliwych dla zdrowia" (art. 39). 
Novum w tym zakresie stanowią także zapisy dotyczące osób niepełnosprawnych, nieobecne w Karcie z 1994 r.:

„1. Państwa będące stronami niniejszej Karty zobowiązują się zapewnić osobom niepełnosprawnym umysłowo lub fizycznie godne życie, które zagwarantuje im godność, zwiększy ich samodzielność i ułatwi aktywne uczestnictwo w życiu społecznym.

2. Państwa będące stronami niniejszej Karty zapewnią bezpłatne usługi socjalne dla wszystkich osób niepełnosprawnych, zapewnią wsparcie materialne potrzebne tym osobom, ich rodzinom lub rodzinom opiekującym się nimi, a także zrobią wszystko, co konieczne dla unikania umieszczania tych osób w instytucjach opiekuńczych. We wszystkich przypadkach uwzględniają najlepszy interes osoby niepełnosprawnej.

3. Państwa będące stronami niniejszej Karty podejmą wszelkie niezbędne środki w celu ograniczenia występowania niepełnosprawności, wszelkimi możliwymi środkami, w tym profilaktycznymi programami zdrowotnymi, podnoszeniem świadomości i edukacją.

4. Państwa będące stronami niniejszej Karty zapewnią wszelkie usługi edukacyjne dostosowane do potrzeb osób niepełnosprawnych, biorąc pod uwagę znaczenie integracji tych osób w systemie edukacji, znaczenie kształcenia zawodowego i przyuczenia do zawodu oraz tworzenia miejsc pracy w sektorze publicznym lub prywatnym

5. Państwa będące stronami niniejszej Karty zapewnią wszelkie odpowiednie usługi zdrowotne osobom niepełnosprawnych, w tym rehabilitację tych osób w celu integracji ze społeczeństwem.

6. Państwa będące stronami niniejszej Karty umożliwią osobom niepełnosprawnym korzystanie ze wszystkich publicznych i prywatnych obiektów usługowych" (art. 40). 
W bardziej szczegółowy sposób aktualna wersja Karty charakteryzuje także sposoby implementacji zasad w niej zawartych, w tym działalności Arabskiej Komisji Praw Człowieka (Lağnat Huqūq al-Insān al-'Arabiyya), do których odniesienia obecne są w art. 44-48.

\section{Podsumowanie}

Dokument, który stał się przedmiotem zainteresowań badawczych autorek niniejszego artykułu - Arabska Karta Praw Człowieka (Al-Mìtāq al-'Arabì li-Huqūq al-Insān) - wydaje się aktem dostosowanym do potrzeb oraz wymogów współczesnego świata i w pełni dorównuje, w aspekcie merytorycznym, konwencjom regulującym te kwestie na poziomie międzynarodowym, takim jak Karta Narodów Zjednoczonych (United Nations Charter), Powszechna Deklaracja Praw Człowieka (Universal Declaration of Human Rights) oraz Międzynarodowe Pakty Praw Człowieka (International Covenants on Human Rights): Międzynarodowy Pakt Praw Gospodarczych, Społecznych i Kulturalnych (Covenant on Economic, Social and Cultural Rights) oraz Międzynarodowy Pakt Praw Obywatelskich i Politycznych (Covenant on Civil and Political Rights).

Innym bowiem zupełnie zagadnieniem, niepodejmowanym w tych rozważaniach, jest problematyka implementacji założeń Karty, która budzi znaczne wątpliwości zarówno wśród komentatorów i badaczy zachodnich, jak i wśród społeczności arabskich i reprezentujących je organizacji oraz instytucji działających na rzecz praw człowieka w świecie islamu. Mimo wielu podobieństw i odwołań do dokumentów międzynarodowych, Arabska Karta Praw Człowieka (Al-Mìt āq al-'Arabì li-Huqūq al-Insān) to z całą pewnością zbiór praw, mocno osadzony w kontekście arabsko-muzułmańskim, co sprawia, 
że wyraźną jego determinantą pozostaje - obok dążenia do zapewnienia ochrony i poszanowania praw człowieka - dążenie do zasygnalizowania i utrwalenia literą prawa specyfiki religijnej i odrębności kulturowej tego obszaru, która implikuje określone rozwiązania w zakresie państwa i społeczeństwa, znajdujące odzwierciedlenie w specyfice obowiązujących praw.

\section{Bibliografia}

\section{Dokumenty źródłowe}

Al-Mìtāa al-'Arabì li-Huqūq al-Insān (Arabska Karta Praw Człowieka) z 15 września 1994 r., w języku arabskim, http:// hrlibrary.umn.edu/arab/a003.html.

Al-Mìtāq al-'Arabì li-Huqūq al-Insān (Arabska Karta Praw Człowieka) z 22 maja 2004 r., w języku arabskim, http:// hrlibrary.umn.edu/arab/a0032.html.

Karta Narodów Zjednoczonych (Charter of the United Nations) w języku polskim, http://www.bb.po.gov.pl/Prawa/ PNZ/KNZ.pdf.

Pakt Praw Gospodarczych, Społecznych i Kulturalnych (Covenant on Economic, Social and Cultural Rights), w języku polskim, http://www.bb.po.gov.pl/Prawa/PNZ/MPPGSK. pdf.

Pakt Praw Obywatelskich i Politycznych (Covenant on Civil and Political Rights), w języku polskim, http://www.bb.po. gov.pl/Prawa/PNZ/MPPOP.pdf.

Powszechna Deklaracja Praw Człowieka (Universal Declaration of Human Rights), w języku polskim, http://www.bb.po. gov.pl/Prawa/PNZ/PDPCZ.pdf. 


\section{Opracowania}

'Abd al-Mun'am A.F., Ğāmi 'at ad-Duwal al-'Arabiyya 1945-85. Dirāsa tārīhiyya siyāsiyya, Bayrūt 1968.

Hammād M. et al., Ğāmi 'at ad-Duwal al- 'Arabiyya. Ru'ya mustaqbaliyya, Al-Qāhira 2014.

Gronowska B., Jasudowicz T., Mik C., Prawa człowieka. Dokumenty międzynarodowe, Toruń 1993.

Gronowska B., Jasudowicz T., Balcerzak M., Lubiszewski M., Mizerski R., Prawa człowieka i ich ochrona, Toruń 2010.

Hołda J., Hołda Z., Ostrowska D., Rybczyńska J.A., Prawa człowieka. Zarys wyktadu, Warszawa 2011.

Rechenberg K., Encyklopedia międzynarodowego prawa publicznego, t. 8, Amsterdam-New York-Oxford,1985.

\section{Źródła internetowe}

http://hrlibrary.umn.edu/arab/a004.html.

http://www.lasportal.org/ar/humanrights/Committee/Pages/ default.aspx.

http://www.lasportal.org/ar/Pages/default.aspx.

http://www.lasportal.org/ar/sectors/dep/HumanRightsDep/ Pages/Committee.aspx.

\section{Abstrakt}

Zagadnienia dotyczące praw człowieka, tak w kontekście krystalizowania się idei tychże praw i jej rozwoju, jak i w aspekcie tworzenia międzynarodowego systemu ochrony praw człowieka i systemów regionalnych, podejmowane były i są dość często zarówno w piśmiennictwie polskim, jak i obcojęzycznym. Autorki skupiły się jednak na jednym, konkretnym przypadku owych zagadnień, osadzając tę problematykę w kontekście działań na rzecz promocji, ochrony i poszanowania praw człowieka w świecie arabskim, w ramach Ligi Państw Arabskich (najstarszej organizacji regionalnej), na przestrzeni siedmiu dekad od momentu jej utworzenia w 1945 r., i w tym zakresie niniejszy artykuł stanowi nowe ujęcie i szczególny ich wkład w dorobek badawczy po- 
święcony tej tematyce. Co więcej, autorki oparły swoje rozważania na arabskojęzycznych tekstach źródłowych - dwóch wersjach Al-Mìtāq al'Arabì li-Huqūq al-Insān (Arabska Karta Praw Człowieka), odpowiednio z lat 1994 i 2004 - które są nieodstępne w całości dla odbiorcy nieposługującego się arabszczyzną, bowiem do chwili obecnej bywały jedynie przytaczane we fragmentach, zaś w polskiej literaturze nie poświęcono im szerszej uwagi. Tłumaczenia zostały opatrzone komentarzami w postaci przypisów, których celem jest charakterystyka dokumentów na tle międzynarodowych aktów normatywnych regulujących ochronę tychże praw (Karta Narodów Zjednoczonych, Powszechna Deklaracja Praw Człowieka, Międzynarodowy Pakt Praw Obywatelskich i Politycznych oraz Międzynarodowy Pakt Praw Społecznych i Gospodarczych), następnie autorki dokonały analizy porównawczej, wskazując zakres i tematykę wprowadzonych w Karcie zmian. Nie budzi wątpliwości fakt, że jednym z głównych zadań statutowych organizacji regionalnych jest zapewnienie promocji, ochrony i poszanowania praw człowieka, a podstawy dla działalności w tym zakresie określają przede wszystkim dokumenty o charakterze międzynarodowym. Jednak specyfika muzułmańskiego kręgu kulturowego, mocno osadzonego w religii i tradycji tego obszaru, sprawia, że zachodnie normy prawne i dokumenty o zasięgu międzynarodowym nie są w stanie - jak się wydaje - zapewnić odpowiedniej ochrony jednostce, bowiem Koran - święta księga wyznawców islamu - reguluje nie tylko wszystkie aspekty życia religijnego, ale dotyka także społecznego i politycznego wymiaru funkcjonowania państwa i jednostki w świecie muzułmańskim. Nierzadko stanowi to istotną przeszkodę $\mathrm{w}$ ratyfikacji przez państwa arabskie (czy szerzej: muzułmańskie) uniwersalnych dokumentów w zakresie ochrony praw człowieka. Próbą rozwiązania tego problemu, a zarazem unormowania tychże kwestii było ustanowienie szeregu mechanizmów ochrony tychże praw w ramach wzmiankowanej Ligi Państw Arabskich. Za największe zaś osiągnięcie działań arabskich na rzecz zapewnienia ochrony i promocji praw człowieka uznano Arabską Kartę Praw Człowieka uchwaloną 22 maja 2004 r. w Tunisie, która weszła w życie w 15 marca $2008 \mathrm{r}$.

Słowa kluczowe: prawa człowieka, system ochrony praw człowieka, akty normatywne ochrony praw człowieka, Liga Państw Arabskich, Arabska Karta Praw Człowieka 


\section{Abstract}

Issues related to human rights, both in the context of the crystallization of the idea of these rights and its development, as well as in the aspect of creating an international system for the protection of human rights and regional systems, have been and are quite often taken up, both in Polish and foreign literature. The authors, however, focused on one specific case of these issues, embedding this issue in the context of actions to promote, protect and respect human rights in the Arab world, within the League of Arab States (the oldest regional organization), over the seven decades since its creation in 1945, and in this respect, this article constitutes a new approach and their specific contribution to the research achievements on this subject. What's more - the authors based their considerations on Arabic-language source texts - two versions of Al-Mìtāq al-'Arabì li-Huqūq al-Insān (Arab Charter of Human Rights), respectively from 1994 and 2004 - which are inaccessible in full to the recipient not using Arabic, because until now they have only been cited in fragments, while in Polish literature they have not been given broad attention. The translations were annotated in the form of footnotes, the purpose of which is to characterize the documents against the background of international normative acts regulating the protection of these rights (United Nations Charter, Universal Declaration of Human Rights, International Covenant on Civil and Political Rights and the International Covenant on Social and Economic Rights), then the authors made comparative analysis, indicating the scope and subject matter of the changes introduced in the Charter. There is no doubt that one of the main statutory tasks of regional organizations is to ensure promotion, protection and respect for human rights, and the foundations for activities in this area are primarily determined by documents of an international nature, but the specificity of the Muslim cultural circle, firmly rooted in religion and tradition of this area, makes Western legal norms and documents of international reach are not able - as it seems - to provide adequate protection to the individual, because the Koran - the holy book of followers of Islam - regulates not only all aspects of religious life, but also affects social and political dimension of the functioning of the state and individual in the Muslim world. This is often a significant obstacle to the ratification by Arab countries (or more broadly: Muslim) of universal documents in the field of human rights protection. An attempt to solve this problem, and at the same time an attempt to normalize these issues was to establish a number of mechanisms to protect these rights within the abovementioned League 
of Arab States. The Arab Charter of Human Rights, adopted on May 22, 2004 in Tunis, which entered into force on March 15, 2008, was recognized as the greatest achievement of Arab efforts to ensure the protection and promotion of human rights.

Keywords: human rights, human rights protection system, normative acts of human rights protection, League of Arab States, Arab Charter on Human Rights 


\section{Aleksandra Raba-Schulze \\ Uniwersytet Szczeciński \\ ORCID ID: https://orcid.org/0000-0003-4847-6131}

\section{Równość płci a status kobiet w Chinach}

\section{Wprowadzenie}

Kobiety stanowią połowę populacji na świecie i jak słusznie zwracają uwagę eksperci, realne postępy w kwestii równości płci wpływają na wszystkie obszary zrównoważonego rozwoju państwa oraz mają kluczowe znaczenie dla realizacji praw człowieka. Niestety nierówność płci wciąż pozostaje problemem ogólnoświatowym, dotyka ona kobiet w momencie narodzin i często jest obecna w całym ich życiu. To kobiety narażone są na społeczne i środowiskowe wykluczenie, doświadczając różnych form niesprawiedliwego traktowania. Łamanie praw człowieka dotyka kobiety w wielu płaszczyznach ich zawodowego funkcjonowania, począwszy od rekrutacji, poprzez zatrudnienie i kolejne etapy kariery zawodowej. Również poza miejscem pracy, to szczególnie kobiety narażone są na molestowanie i wykorzystywanie seksualne oraz są ofiarami przemocy domowej. Problemy te mogą się wyróżniać szczególnie w Chinach, gdzie miejsce kobiet w społeczeństwie w dużej mierze zostało ukształtowane przez kulturę patriarchalną. W konfucjańskim, hierarchicznym społeczeństwie niski status kobiet był głęboko zakorzeniony. Kobiety pozostawały na utrzymaniu męża bez autonomii w jakimkolwiek aspekcie życia społecznego, pozbawione „praw człowieka”" Rola kobiet sprowadzała się do roli

1 S. Yife, Feminism in China, An Analysis of Advocates, Debates and Strategies, „Counntry Study, Friedrich Ebert Stiftung” 2016, s. 6. 
pokrewieństwa: córka, siostra, żona, synowa, matka i teściowa. Wszystkie te role sprowadzały się do spełniania życzeń spokrewnionych mężczyzn². Tradycyjnie używano filozofii „ying-yang" do określenia relacji między płciami, wprost narzucając dominację jednej płci nad drugą. W tych nierównych, zdominowanych przez mężczyzn relacjach, kobieta podlegała systemowi społecznemu, w którym jej główną rolą była opieka nad mężem i wychowywanie synów. Kobiety wykluczano ze sfery publicznej, rządowej i rynku pracy. Nauczano, że „cnotą jest, że kobieta nie ma zdolności”, a twierdzenie, że „niezdolny mężczyzna jest lepszy niż zdolna kobieta" miało zapobiec udziałowi kobiet w sile roboczej ${ }^{3}$. Właściwą rolę kobiet kształtowała zasada znana jako „trzy posłuszeństwa i cztery cnoty”, według której kobieta miała być posłuszna ojcu przed zawarciem związku małżeńskiego, posłuszna mężowi w trakcie trwania małżeństwa oraz podążać za synem jako wdowa ${ }^{4}$. Natomiast model dobrej kobiety, tj. podporządkowanej mężczyźnie wyznaczały cztery cnoty: cnota moralna, cnota języka, cnota maniery i cnota pracy ${ }^{5}$. Chińskie kobiety doświadczały długotrwałego ucisku i poniżenia, obraźliwe praktyki i zachowania, jak sprzedaż i zakup kobiet, dzieciobójstwo czy bicie nie były rzadkością ${ }^{6}$. Warto w tym miejscu wspomnieć o jednej z najbardziej brutalnych praktyk, jaką było krępowanie kobietom stóp. Tortury te, którym poddawano już trzyletnie dziewczynki miały na celu podniesienie wartości mło-

2 Traditional Women's Roles in China, http://factsanddetails.com/china/cat3/sub9/entry-5562.html\#chapter-1 [dostęp 12.08.2019].

3 J. Burnett, Women's Employment Rights in China, „Indiana Journal of Global Legal Studies” 2010, vol 17, s. 294.

4 J.A. Stowell, The Influence of Cnfucian Values on Interpersonal Communication in South Korea, as Compared to China and Japan, „Intercultural Communication Studies" 2003, nr XII-4, s. 107.

5 Ibidem, s. 108.

6 Y. Li, Women's Movemnet and Change of Women's Status in China, „Journal of International Women's Studies” 2000, s. 31. 
dych chińskich kobiet ${ }^{7}$. Wielkość stóp była wyznacznikiem wartości kobiety i gwarantem poślubienia „bogacza” - im mniejsza była stopa, tym większa była szansa awansu społecznego. Ideałem była siedmiocentymetrowa stopa i aby osiągnąć ten „ideał” małym dziewczynkom łamano kości małych palców i podbicia, przez co były narażone nie tylko na przewlekły ból, ale także zanik mięśni czy paraliż ${ }^{9}$. Był to jeden z najbardziej brutalnych przykładów uprzedmiotowienia kobiet.

Jednym z ważniejszych wydarzeń w kierunku poprawy statusu kobiet była rewolucja komunistyczna w 1949 r. Komunistyczna Partia Chin optowała od samego początku za równością kobiet i mężczyzn. Zaprzestano promowania wizerunku kobiet jako słabych fizycznie, skromnych istot podporządkowanych mężczyznom, a wprowadzono wizerunek kobiety silnej, asertywnej, w rolach, które wcześniej były zarezerwowane tylko dla mężczyzn ${ }^{10}$. W czerwcu 1949 r. Mao Zedong, chcąc zachęcić kobiety do zjednoczenia się i działalności na rzecz poprawy statusu kobiet, zarówno politycznego, jak i ekonomicznego powołał pozarządową organizację All-China Womens Federation $(\mathrm{ACAF})^{11}$. Głównymi celami organizacji było zmobilizowanie kobiet do udziału w reformach oraz edukowanie i świadczenie usług dla kobiet oraz dzieci. Organizacja wciąż działa i prowadzi regularne kampanie uświadamiające korzyści wynikające ze stosowania zasady równości płci ${ }^{12}$. Chociaż ówczesna partia promowała równość płci, wciąż jednak istniały nierówności,

7 A. Lipka, Siostry Kopciuszka. O krępowaniu stóp w Chinach, „Loża Wschodu" 2012, nr 1 (2), s. 13.

8 Ibidem, s. 18.

9 Ibidem.

10 Country Briefing Paper, Women in the People's Republic of China, 1992, s. 12, https://www.adb.org/sites/default/files/institutional-document/32565/women-peoples-republic-china.pdf [dostęp: 10.09.2019].

11 Ibidem, s. 23.

12 Ibidem, s. 57. 
szczególnie w dostępie do niektórych miejsc pracy i kierunków studiów $^{13}$. W dalszym ciągu, szczególnie na terenach wiejskich, wśród klasy chłopskiej pozostała silna tradycja preferowania syna, a córka w dalszym ciągu była postrzegana jako „tymczasowy” członek gospodarstwa domowego i chociaż powszechnie popierano równość płci, to synów uważano za bardziej „równych" niż córki ${ }^{14}$. Istotną zmianą, wpływającą na pozycję kobiet była uchwalona w 1950 r. ustawa o małżeństwie, która składała się z 27 artykułów ${ }^{15}$. Nowa ustawa zagwarantowała kobietom wolny wybór partnera, znosząc tym samym hierarchiczne podporządkowanie rodzicom i mężczyznom ${ }^{16}$. Odcięto się również od wcześniejszej powszechnej tradycji, kiedy dziecko zaręczane było w chwili urodzenia, ustalono nowy wiek, w którym można zawierać małżeństwa: dla mężczyzn było to 20 lat, a dla kobiet $18^{17}$. Ponadto, dzięki nowej ustawie, wdowy otrzymały możliwość ponownego zamążpójścia, dzięki czemu nie były już zależne od rodziny, a wszystkim kobietom przyznano prawo do rozwodu. Warto przypomnieć, że w tradycyjnych Chinach, kobieta, która podjęła decyzję o rozwodzie była wykluczana ze społeczności, zostawała bez środków do życia, co w wielu przypadkach prowadziło do samobójstwa ${ }^{18}$. Dodatkowo kobiety otrzymały prawo do pozostania przy swoim nazwisku i po raz pierwszy otrzymały prawo do dziedziczenia, zarządzania własnym majątkiem, co sprawiło, że stały się bardziej niezależne ekonomicznie.

13 Ibidem, s. 22.

14 Ibidem, s. 23.

15 A. Błaszczyk, M. Sikora, Kilka uwag o prawno-społecznym statusie kobiet w Chińskiej Republice Ludowej, „Wrocławskie Studia Erazmiańskie” 2015, nr IX, s. 236.

16 S. Green Dorros, The Status of Women in the People's Republic of China, s. 31, https://www.asj.upd.edu.ph/mediabox/archive/ASJ-16-1978/ dorros-women-china.pdf [dostęp 11.09.2019].

17 S. Green Dorros, The Status..., op.cit., s. 33.

18 Ibidem, s. 35. 
Jak już wspomniano, Komunistyczna Partia Chin popierała idee równości kobiet i mężczyzn należy jednak przypomnieć, że wprowadzona w 1977 r. polityka jednego dziecka spowodowała znaczny niedobór kobiet w populacji. Jedną z niezamierzonych konsekwencji radykalnej polityki planowania rodziny jest nienaturalna równowaga płci. Silna preferencja kulturowa posiadania syna w połączeniu z nakazem posiadania jednego potomka i technologią umożliwiającą określenie płci doprowadzała do selektywnych aborcji. Warto przypomnieć, że aborcja selektywna została zakazana w 1994 r., natomiast dopiero w 2002 r. w prawie o ludności i planowaniu rodziny zakazano dyskryminacji oraz złego traktowania kobiet rodzących córkę $e^{19}$. Szacuje się, że w latach 1980-2000 dokonano ich około $4 \mathrm{mln}^{20}$. Dodatkowo dziewczynki były porzucane w sierocińcach, gdzie często umierały z powodu panujących w nich ekstremalnie złych warunków ${ }^{21}$. Przymusowa polityka planowania rodziny pogorszyła pozycję kobiety, zwłaszcza na obszarach wiejskich. Kobiety stały się ofiarami mechanizmów ucisku i presji zarówno ze strony państwa jak i rodziny ${ }^{22}$. Należy podkreślić, że polityka planowania rodziny, implementowana za pomocą systemu kar i nagród nie była zgodna z art. 16 ust. 1 lit. e) CEDAW, w którym potwierdzono, iż kobiety mają prawo decydować o liczbie posiadanych dzieci² ${ }^{23}$.

19 I. Attané,Tam, gdzie dzieci sq̨ luksusem, Warszawa 2102, s. 109.

20 M. Koetse, How the One - Child Policy Has Improved Women's Status in China, https://www.whatsonweibo.com/one-child-policy-improved-womens-status-china/ [dostęp: 12.09.2019].

21 Ż. Rachwaniec-Szczecińska, Synowie jedynacy i znikajace córki o pozycji kobiet w Chinach, „Pisma Humanistyczne” 2013, nr 9, s. 224.

22 K. Tomala, Planowanie rodziny warunkiem modernizacji kraju, [w:] Chiny. Przemiany państwa i społeczeństwa w okresie reform 1978-200, red. eadem, Warszawa 2003, s. 2, 92.

23 Inquiry into access to contraception in Manila: CEDAW Committee finds that the Philippines violated CEDAW, https://opcedaw.wordpress.com/ category/cedaw-article/cedaw-art-161e/ [dostęp: 20.08.2019]. 
Równość płci, o której mowa w niniejszym artykule, to zapewnienie obu płciom równych szans na niezależność ekonomiczną, równy dostęp do edukacji oraz stworzenie warunków umożliwiających dokonywanie takich wyborów życiowych, które wynikają z ich osobistych potrzeb, aspiracji czy talentów ${ }^{24}$. Dążenie do równości płci oznacza zmiany dla kobiet i mężczyzn, polegające na przedefiniowaniu praw i obowiązków panujących w społeczeństwie, środowisku pracy i rodzinie. Istotne jest, aby podkreślić, że równość, o której mowa, nie polega na zrównaniu mężczyzn i kobiet w cechach, które wywodzą się z biologii, ale polega na tworzeniu takich sytuacji, w których różnice wywodzące się z płci kulturowej nie będą powodować wykluczenia z żadnej sfery życia ani tworzyć sytuacji nierówności. Należy zwrócić uwagę, że wciąż tam, gdzie pojawiają się nierówności, to kobiety mają ograniczony dostęp do zasobów gospodarczych czy społecznych. W wyniku tych barier, to kobiety są niedoreprezentowane w procesach podejmowania decyzji gospodarczych i politycznych, osiągają mniejsze dochody i posiadają mniej aktywów. Zatem istotnym aspektem w dążeniu do równości płci jest wzmocnienie pozycji kobiet poprzez zapewnienie kobietom większej autonomii tak, aby ich możliwości czy zmiany życiowe nie były ograniczone przez płeć. W tym miejscy należy zaznaczyć, iż płeć, o której jest mowa w niniejszym artykule, definiowania jest jako to, co w określonym społeczeństwie lub kulturze postrzegane jest za odpowiednie dla kobiet i mężczyzn. Za odpowiednie rozumiane są role społeczne, które w sposób jednoznaczny przypisywane są kobietom i mężczyznom zgodnie z oczekiwaniami społeczeństwa i stanowią jaki powinien być „prawdziwy mężczyzna” i jaka powinna być „prawdziwa ko-

24 J. Piotrowska, A. Siekiera, A. Sznajder, Jak realizować zasadę równości szans kobiet $i$ mężczyzn, Warszawa 2016, s. 15. 
bieta"25. Głównym celem równości płci jest stworzenie takich warunków w społeczeństwie, w których zarówno kobiety, jak i mężczyźni mogą korzystać z tych samych praw, obowiązków oraz możliwości, w których są wolni od dyskryminacji i przemocy uwarunkowanej płciąa ${ }^{26}$. Celem podejścia równościowego jest również przeciwdziałanie stereotypom płci, które odnoszą się zarówno do kobiet, jak i do mężczyzn. Stanem docelowym zatem jest wybór drogi życiowej bez ograniczeń, które przejawiają się poprzez stereotypowe postrzeganie płci oraz przypisywanie tejże płci ról społecznych, które powiązane są tą perspektywą uprzedzeń. Osiągnięcie takiego stanu wymaga jednak wyeliminowania pierwotnych przyczyn dyskryminacji, dotyczących zwłaszcza kobiet, które są wynikiem głęboko zakorzenionych postaw patriarchalnych ${ }^{27}$.

\section{Równość płci - regulacje międzynarodowe i krajowe w Chinach}

Obecne prawo równościowe czerpie z dorobku prawnego ONZ, dla którego równość płci jest jedną z fundamentalnych zasad. W tym miejscu warto podkreślić, iż historyczną zmianę $\mathrm{w}$ dyskursie politycznym i pierwszym traktatem wzywającym do równości kobiet i mężczyzn była Karta Narodów Zjednoczonych. Kwestie, które wcześnie były uważane za tradycyjne czy prywatne stały się przedmiotem otwartej debaty na poziomie globalnym, aby kobiety w pełni korzystały z przysłu-

25 M. Jonczy-Adamska, Pteć kulturowa - stownik, https://rownosc.info/ dictionary/pec-kulturowa/ [dostęp: 1.08.2019].

26 United Nations Population Found, Frequently asked questions about gender Equality, 2005, https://www.unfpa.org/resources/frequently-askedquestions-about-gender-equality [dostęp: 10.08.2019].

27 UNDP, Goal 5: Geneder Equality, https://www.sdfinance.undp.org/ content/sdfinance/en/home/sdg/goal-5--gender-equality.html [dostęp: 2.08.2019]. 
gujących im praw. Z upływem lat ONZ stworzyła standardy i programy, które podnoszą status kobiet na całym świecie. Jednym z najistotniejszych działań ONZ na rzecz kobiet była przyjęta w dniu 18 grudnia 1979 r. Konwencja w sprawie likwidacji wszelkich form dyskryminacji kobiet (CEDAW), która jako traktat międzynarodowy weszła w życie 3 września 1981 r. $^{28}$ Konwencja została ratyfikowana przez 187 państw ${ }^{29}$, które przyjęły szerokie obowiązki w zakresie promowania równości kobiet i mężczyzn we wszystkich sferach życia publicznego i prywatnego oraz wyeliminowania dyskryminacji kobiet zarówno pośredniej, jak i bezpośredniej. Chiny ratyfikowały CEDAW w 1980 r. i stały się jednym z pierwszych państw sygnatariuszy. Po raz pierwszy w Konwencji, jako dokumencie międzynarodowym, zostało zdefiniowanie pojęcie dyskryminacji kobiet, która rozumiana jest jako „wszelkie rozróżnienie, wykluczenie lub ograniczenie ze względu na płeć [...] w dziedzinach życia politycznego, gospodarczego, społecznego i każdej innej”. Program na rzecz równości jest bardzo szeroki i w swoim podejściu obejmuje kwestie dotyczące stereotypów związanych z płcią (art. 5), handlu kobietami i prostytucji (art. 6), potwierdza prawa kobiet do niedyskryminacji w zakresie zatrudnienia, działalności gospodarczej i społecznej oraz edukacji (art. 10, 11, 13). Zapewnia kobietom równość w sprawach cywilnych i handlowych domagając się, aby wszelkie instrumenty ograniczające zdolności prawne kobiet zostały uznane za nieważne (art. 15).

Dążąc do ustanowienia fundamentów pod konkretne działania, mające na celu wprowadzenie równości kobiet i męż-

28 Convention on the Elimination of All Forms of Discrimination against Women New York, 18 December 1979, https://www.ohchr.org/en/ professionalinterest/pages/cedaw.aspx [dostęp: 29.12.2018].

29 Cedaw the $66^{\text {th }}$ Session, https://www.soroptimistinternational.org/ cedaw-66th-session/ [dostęp: 29.12.2018]. 
czyzn w aspekcie faktycznym i prawnym, Organizacja Narodów Zjednoczonych zwołała w Pekinie IV Światową Konferencję w sprawie Kobiet, podczas której przyjęto deklarację pekińską i platformę działania. Konferencja, która miała miejsce we wrześniu w 1995 r. wyznaczyła punkt zwrotny dla globalnej agendy równości płci i była przełomem w postrzeganiu praw kobiet i mężczyzn. Deklaracja pekińska i platforma działania wyznaczyły strategiczne cele i działania na rzecz awansu kobiet i osiągnięcia równości płci w dwunastu najważniejszych obszarach, które obejmowały zakres od ubóstwa, edukacji i przemocy po gospodarkę oraz prawa kobiet. Dzięki przyjęciu deklaracji pekińskiej i platformy działania rządy, społeczeństwo obywatelskie oraz wszystkie inne zainteresowane strony podejmują pracę nad wyeliminowaniem dyskryminacji kobiet i dziewcząt oraz osiągnięciem równości w każdej dziedzinie życia w przestrzeni zarówno publicznej, jak i prywatnej. Deklaracja i jej plan działania wciąż stanowią inspirację oraz źródło wskazówek do realizacji polityki równościowej. Po konferencji w Pekinie rząd chiński podjął działania na rzecz poprawy praw pracowniczych kobiet oraz działania mających na celu ograniczenie dyskryminacji ze względu na płeć. Wdrożono podstawową politykę krajową dotyczącą równości płci, która promowała wszechstronny rozwój chińskich kobiet w dziedzinie zdrowia, edukacji, gospodarki ${ }^{30}$. Rząd rozpoczął również zachęcać lokalne samorządy do podejmowania działań na rzecz rozwoju kobiet ${ }^{31}$.

Istotnym przełomowym wydarzeniem $\mathrm{w}$ działaniach ONZ na rzecz równości płci był Szczyt Milenijny w 2000 r., gdzie w oparciu o dekadę najważniejszych konferencji i szczytów ONZ światowi przywódcy spotkali się w siedzibie ONZ w Nowym Jorku i przyjęli Deklarację Milenijną Narodów Zjednoczo-

\footnotetext{
30 J. Burnett, Women's Employmen..., op.cit., s. 297.

31 Ibidem.
} 
nych $^{32}$. Deklaracja zobowiązała państwa do nowego, globalnego partnerstwa na rzecz ograniczenia skrajnego ubóstwa i wyznaczyła osiem celów z terminem ich realizacji do 2015 r. Polityka równości płci i awansu społecznego stanowi cel trzeci przyjętej Deklaracji, realizowany poprzez eliminację różnic między płciami w szkołach podstawowych i średnich oraz na wszystkich poziomach edukacji najpóźniej do 2015 r. Potwierdzono tym samym, że inne cele nie mogą być osiągnięte bez rzeczywistego uprawnienia płci ${ }^{33}$. Należy podkreślić, że po Szczycie Milenijnym w Chinach uruchomiono kolejny program dotyczący rozwoju kobiet na lata 2001-2010, którego celem było promowanie edukacji, dbałość o zdrowie matek i dzieci oraz niedyskryminacja kobiet ${ }^{34}$. Istotne jest, iż w programie położono nacisk na odpowiedzialność państwa za ochronę praw kobiet ${ }^{35}$.

Należy podkreślić, że Konwencja w sprawie likwidacji wszelkich form dyskryminacji kobiet, Platforma w Pekinie oraz Deklaracja Milenijna Narodów Zjednoczonych doprowadziły do znaczącego pozytywnego ruchu kobiet na rzecz równości płci na świecie. Zwiększono, choć niewystarczająco, świadomość, że edukacja jest jednym z najistotniejszych sposobów osiągnięcia równości płci i wzmocnienia pozycji kobiet. Rządy prawie wszystkich państw wprowadziły zmiany prawne i konstytucyjne, aby zwiększyć reprezentację kobiet w procesie kształtowania polityki publicznej.

32 Rezolucja przyjęta na 55. sesji Zgromadzenia Ogólnego Narodów Zjednoczonych, Deklaracja Milenijna Narodów Zjednoczonych, http://www. unic.un.org.pl/dokumenty/deklaracja_milenijna.doc [dostęp: 29.12.2018].

33 E. Jastrzębska, Polityka genderowa Unii Europejskiej - geneza i ewolucja, „Kwartalnik Kolegium Ekonomiczno-Społecznego. Studia i Prace” 2014, nr 2, s. 207.

34 T. Angeloff, M. Lieber, Equality Did You Say?, „China Perspectives” 2012, nr 4, s. 20.

35 Ibidem. 
Ochrona prawna kobiet w Chinach gwarantowana jest na mocy Konstytucji. Dodatkowo uregulowana jest również w ustawie o ochronie praw i interesów kobiet, wspomnianym już prawie małżeńskim, prawie pracy oraz prawie karnym. Konstytucja Chińskiej Republiki Ludowej z 1982 r., w art. 33 stanowi, że „wszyscy obywatele Chińskiej Republiki Ludowej są równi wobec prawa", natomiast art. 48 szczegółowo odnosi się do statusu kobiet i stanowi, że: „Kobiety w Chińskiej Republice Ludowej mają równe prawa z mężczyznami we wszystkich dziedzinach życia, tj. w sferze politycznej, gospodarczej, kulturalnej, rodzinnej i społecznej"36. Istotną zmianą, przyczyniającą się do eliminacji dyskryminacji ze względu na płeć była ustawa z dnia 3 kwietnia 1992 r. o ochronie praw i interesów kobiet. W ustawie ponownie zwrócono uwagę, że równość płci oraz eliminacja wszelkich form dyskryminacji jest podstawową polityką państwa. Ustanowiono również przepisy dotyczące udziału w kobiet w życiu politycznym oraz w zakresie zatrudnienia ${ }^{37}$. Ustawę znowelizowano w 2005 r. i aktualnie składa się z 61 artykułów ${ }^{38}$. Również chińskie prawo pracy gwarantuje równouprawnienie w dostępie do zatrudnienia oraz równego wynagrodzenia bez względu na płeć. Prawo pracy gwarantuje kobietom ochronę podczas ciąży i po porodzie, jak również każdej kobiecie nie mniej niż 90 dni urlopu macierzyńskiego ${ }^{39}$. Należy jednak wskazać, że istnieją przepisy, które ograniczają możliwości kobiet. Kobietom zabrania się prac na dużych wysokościach, kopalniach oraz takich, które wymagają przenoszenia ciężarów powyżej 25 kilogramów i innych skla-

36 Human Rights Brief, Women in China, https://www.refworld.org/ docid/3ae6a81020.html [dostęp: 12.09.2019].

$37 \mathrm{Z}$. Xiaobing, The Ratyfication an Implementation of CEDAF in China, 2017, http://www.chinahumanrights.org/html/2017/MAGAZINES_0504/7976.html [dostęp: 12.09.2019].

38 A. Błaszczyk, M. Sikora, Kilka uwag..., op.cit., s. 238.

39 Ch.J. Ogletree, When Gender Differences Become a Trap. The Impact of China's Labor Law an Women, „Yale Journal of Law and Feminism” 2002, s. 76. 
syfikowanych jako intensywnie fizyczne ${ }^{40}$. Dodatkowo zabrania się kobietom podczas miesiączkowania prac w zimnej wodzie czy niskiej temperaturze, a kobiety które są powyżej siódmego miesiąca ciąży nie mogą podjąć pracy na nocnej zmianie, nie mają również prawa do nadgodzin ${ }^{41}$. Ograniczenia te mogą wydawać się przejawem troski jednak należy zauważyć, że koncentrują się one na różnicach biologicznych, promując tym samym pogląd, że głównym obowiązkiem kobiet jest rodzenie dzieci i dbanie o rodzinę. Tym samym prawo, które zabrania nierównego traktowania umożliwia segregację na rynku pracy ${ }^{42}$. W tym miejscu należy wspomnieć, że również prawo karne Chińskiej Republiki Ludowej z 1979 r. penalizuje czyny zabronione przeciwko kobietom ${ }^{43}$. Szczególnie istotny jest art. 236 w rozdziale IV dotyczącym przestępstw polegających na naruszeniu obywatelskiego prawa, który stanowi, że „każdy, kto gwałci kobietę za pomocą przemocy, przymusu lub w jakikolwiek inny sposób powinien być skazany na karę pozbawienia wolności na czas nie krótszy niż trzy lata, ale nie dłuższy niż 10 lat"44. Niestety ustawodawstwo nie dotyczy gwałtu małżeńskiego, a kobieta może złożyć skargę na podstawie ww. artykułu.

\section{Status kobiet w Chinach - równość czy dyskryminacja?}

Ponad dwie dekady po historycznym punkcie zwrotnym dla globalnej agendy równości płci jakim była deklaracja pekińska i platforma działania, Chiny opublikowały we wrześniu 2015 r.

40 Ch.J. Ogletree, When Gender..., op.cit., s. 77.

41 A. Błaszczyk, M. Sikora, Kilka uwag..., op.cit., s. 244.

42 Ch.J. Ogletree, When Gender..., op.cit., s. 78.

43 A. Błaszczyk, M. Sikora, Kilka uwag..., op.cit, s. 245.

44 Criminal Law of the People's Republic of China, s. 50, https:// www.ilo.org/dyn/natlex/docs/ELECTRONIC/5375/108071/F-78796243/ CHN5375\%20Eng3.pdf [dostęp: 12.08.2019]. 
Białą Księgę w sprawie równości płci i rozwoju kobiet. Rząd chiński zapewnił w niej, że podejmuje nieustanne wysiłki mające na celu ochronę praw i interesów kobiet, w tym do poprawy systemu prawnego, wzmocnienia świadomości społecznej i wdrażania odpowiednich programów ${ }^{45}$. W tym miejscu należy zwrócić uwagę, że według The Global Gender GAP Chiny w 2018 r. zajęły $103 .{ }^{46}$ miejsce na liście 144 państw w zakresie równości płci, w dziedzinie zdrowia, edukacji, gospodarski oraz polityki. Dodatkowo w przeglądzie wdrażania przez Chiny CEDAW w 2014 r. Ogólnochińska Federacja Kobiet oraz Chińskie Towarzystwo Badawcze Kobiet wskazało na szeroki zakres problemów dotyczących wyżej wskazanych obszarów.

Pierwszym z obszarów, na który należy zwrócić uwagę jest dyskryminacja ze względu na płeć w zatrudnieniu. Jak już wspomniano prawo pracy Chińskiej Republiki Ludowej, a także ustawa o promocji i zatrudnieniu zawierają przepisy dające przyzwolenie pracodawcy na wykluczenie kobiet z niektórych stanowisk. Warto zwrócić uwagę, że w Chinach zauważalny jest brak kobiet na stanowiskach kierowniczych. Tylko 17\% kadry kierowniczej stanowią w Chinach kobiety, dodatkowo 50\% chińskich kobiet jest zatrudnionych na stanowiskach sprzedażowych czy księgowych, tym samym osiągają one niższe dochody niż w branżach produkcyjnych czy technologicznych ${ }^{47}$. Jedną z przeszkód, która utrwala tą nierówność są dyskryminujące ze względu na płeć ogłoszenia o pracę. W 2018 r. organizacja Human Right Watch przeanalizowała około 36 tys. ogłoszeń o pracę w latach 2013-2018, które publikowane były na portalach

45 Gender Equality and Women's Development in China, http://www. china-un.ch/eng/rqrd/jblc/t210715.htm [dostęp: 7.08.2019].

46 The Global Gender GAP Report 2018, s. 16, http://www3.weforum. org/docs/WEF_GGGR_2018.pdf [dostęp: 1.09.2019].

47 China Power, Do women in China face greater inequality than women elsewhere?, https://chinapower.csis.org/china-gender-inequality/ [dostęp: 1.08.2019]. 
społecznościowych oraz stronach firm rekrutujących ${ }^{48}$. Stwierdzono, że wiele ogłoszeń wyraźnie wskazuje, że pracodawca preferuje kandydata płci męskiej, a w części ogłoszeń wymagano od kobiet takich cech fizycznych, które nie miały nic wspólnego $\mathrm{z}$ umiejętnościami wymaganymi na określone stanowisko ${ }^{49}$. Obsadzanie stanowisk pracy na podstawie stereotypowego podziału ról na męskie i damskie utrudnia rozwój zawodowy kobiet i pogłębia finansową zależność kobiet od mężczyzn. Przepisy zakazujące dyskryminacji ze względu na płeć podczas rekrutacji zmieniły się dopiero 18 lutego 2019 r. Zgodnie z nowymi przepisami pracodawcy, zamieszczający dyskryminujące ze względu na płeć ogłoszenie o pracę, będą podlegali surowszym karom w wysokości od 10 tys. do 50 tys. RMB (od 1,4 tys. do 7 tys. USD). Aktualne prawo zabrania również pracodawcy pytania kobiet ubiegających się o pracę o ich stan cywilny, ograniczenia dostępu do pracy ze względu na płeć, wymagania od kobiet zrobienia testu ciążowego oraz wymagania zgody na nieposiadanie dziecka jako warunku zatrudnienia ${ }^{50}$.

Kolejnym przykładem nierówności płci w Chinach jest niski udział kobiet w życiu politycznym. Chińska Konstytucja wyraźnie określa, że kobiety i mężczyźni mają równe prawa polityczne, a rząd oficjalnie popiera równość płci i wzmacnia zdolność kobiet do angażowania się w sprawy polityczne ${ }^{51}$. Niestety kobiety w Chinach wciąż są niedostatecznie reprezentowane i za-

48 Human Rights Watch, China. Job ads Discriminate Against Women, https://www.hrw.org/news/2018/04/23/china-job-ads-discriminate-against-women [dostęp: 20.07.2019].

49 R. Rincon, Gender Discrimination in China, 2018, https://alltogether. swe.org/2018/04/gender-discrimination-in-china/ [dostęp: 3.09.2019].

50 F. Webster, S. Rosseau, China Strngthens Gender Equality, https:// www.mercer.com/our-thinking/law-and-policy-group/china-strengthens-gender-equality.html [dostęp 12.09.2019].

51 Gender Equality and Women's Development in China, http://www. china-un.ch/eng/rqrd/jblc/t210715.htm [dostęp 7.08.2019]. 
angażowane w podejmowanie decyzji politycznych ${ }^{52}$. W 2017 r. członkostwo kobiet w KPCh wynosiło jedną czwartą całkowitego członkostwa partii, żadna kobieta nie zasiadała w Stałym Komitecie Biura Politycznego Chin ani nie sprawowała prezydencji ${ }^{53}$. Aktualnie spośród 31 administracji na szczeblu prowincji żadna kobieta nie jest sekretarzem partii w prowincji ani w gminie ${ }^{54}$. Aby zachęcić kobiety do większej aktywności w życiu politycznym Federacja Kobiet wspierała programy szkoleniowe w latach 2011-2015, który dotyczyły głównie uczestnictwa politycznego kobiet wiejskich ${ }^{55}$. Programy miały na celu zwiększenie wpływu kobiet w samorządach lokalnych oraz poprawę przepisów i polityki w tym zakresie w prowincjach Shanxi, Heilongjiang i Hunan ${ }^{56}$. Kobiety biorące udział w szkoleniach uczyły się umiejętności prowadzenia kampanii oraz współpracy z kobietami i mężczyznami na stanowiskach kierowniczych. Program doprowadził do wzrostu liczby kobiet aktywnych politycznie w prowincjach biorących w nim udział ${ }^{57}$. Warto podkreślić, że wśród

52 A Brief Report on the Combined Seventh and Eighth Periodic Report Submitted by China under Article 18 of the Convention on the Elimination of All Forms of Discrimination against Women, s. 3, https://tbinternet.ohchr. org/Treaties/CEDAW/Shared\%20Documents/CHN/INT_CEDAW_NGO_ CHN_18130_E.pdf [dostęp: 2.08.2019].

53 China Power, Do women in China face greater inequality than women elsewhere?, https://chinapower.csis.org/china-gender-inequality/ [dostęp: 1.08.2019].

54 Ch. Li, Status of China's women leaders on the eve of $19^{\text {th }}$ Party Congress, 2017, https://www.brookings.edu/opinions/status-of-chinas-womenleaders-on-the-eve-of-19th-party-congress/ [dostęp: 3.09.2019].

55 China Power, Do women in China face greater inequality than women elsewhere?, https://chinapower.csis.org/china-gender-inequality/ [dostęp: 1.09.2019].

56 UN Woman, Women gain political representation and Leadership in rural China, 2016, https://www.unwomen.org/en/news/stories/2016/9/ women-gain-political-representation-and-leadership-in-rural-china [dostęp: 28.08.2019].

57 UN Woman, Women gain political representation and Leadership in rural China, 2016, https://www.unwomen.org/en/news/stories/2016/9/ 
czynników wpływających na niski udział kobiet w życiu politycznym, zwłaszcza na terenach wiejskich jest fakt, że kobiety wciąż nie są w pełni świadome swoich praw politycznych ${ }^{58}$. Ponadto niski poziom wykształcenia wpływa na ich zdolność do udziału w życiu politycznym ${ }^{59}$, w dalszym ciągu podporządkowując je tradycyjnej roli żony i matki.

Istotnym aspektem realizacji polityki równościowej jest równy dostęp do edukacji. W celu zwiększenia dostępu do edukacji oraz poprawy jej jakości, chiński rząd wprowadził ustawę o dziewięcioletniej obowiązkowej edukacji w 1986 r. oraz ustawę o edukacji Chińskiej Republiki Ludowej z 1995 r. Rozwój edukacji na dużą skalę sprawił, że szkolnictwo podstawowe i wyższe stało się bardziej dostępne, a wśród istotnych postępów należy wymienić wzrost wskaźnika umiejętności czytania i pisania wśród kobiet. Wskaźnik ten w 2017 r. wynosił 92,7\% i wzrósł on o $6,2 \%$ w porównaniu z 2000 r. ${ }^{60}$ Pomimo dużego postępu w tym zakresie należy zauważyć, że w światowym rankingu Chiny wciąż zajmują niską pozycję w porównaniu do państw z wysoko rozwiniętymi gospodarkami, gdzie wskaźnik umiejętności czytania wynosi ponad 99\%. Warto podkreślić, że dzięki przepisom o obowiązkowej edukacji, powszechne stały się zapisy do szkół podstawowych, a średni czas nauki kobiet w Chinach wzrósł z 4,8 lat w 1990 r. do 7,6 lat w 2017 r. ${ }^{61}$ Ponadto od 2009 r.

women-gain-political-representation-and-leadership-in-rural-china [dostęp: 28.08.2019].

58 C. Huang, Why Low Political Participation of Rural Women in China: An Interpretation from Neo-Institutionalism Perspective, „Open Journal of Political Sciense" 2018, nr 8, s. 254.

59 C. Huang, Why Low Political..., op.cit., s. 257.

60 China Power, How does education in China compere with others countries?, https://chinapower.csis.org/education-in-china/ [dostęp: 27.08.2019].

61 China Power, Do women in China face greater inequality than women elsewhere?, https://chinapower.csis.org/china-gender-inequality/ [dostęp: 1.09.2019]. 
wzrasta stosunek kobiet do mężczyzn w szkolnictwie wyższym, co zaprezentowano na poniższym wykresie:

Wykres 1. Udział kobiet i mężczyzn w szkolnictwie wyższym

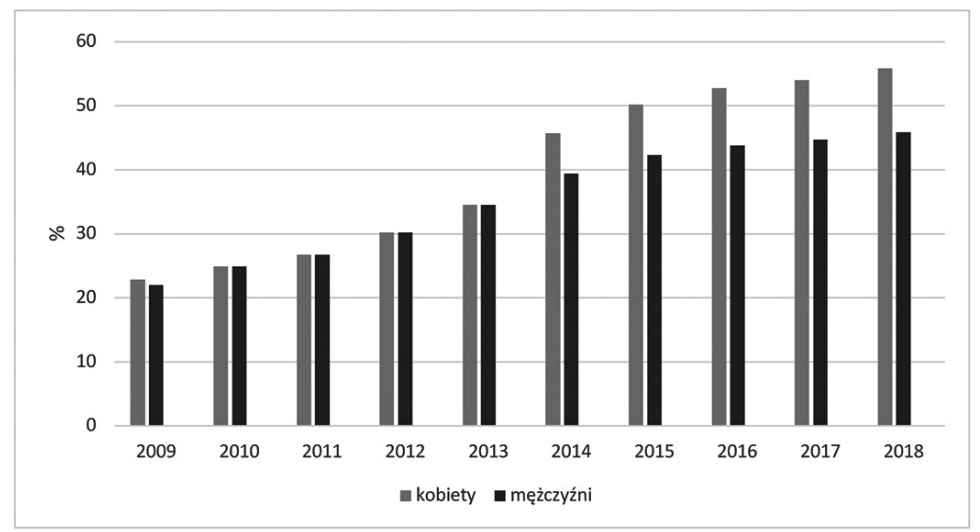

Źródło: opracowanie własne na podstawie: http://uis.unesco.org/en/ country/cn.

Jak już wspomniano, kobiety na obszarach wiejskich w Chinach wciąż narażone są na bariery w dostępie do edukacji. Jednym z głównych powodów tej nierówności są w dalszym ciągu niższe oczekiwania rodziców mających córkę, a także mniejsze szanse na zatrudnienie kobiet z obszarów wiejskich. Ponadto dziewczęta z obszarów wiejskich często zmuszane są przez rodzinę do rezygnacji z nauki i rozpoczęcia pracy, aby wspomóc rodziców ${ }^{62}$. Warto przytoczyć wyniki Raport China Social Welfare Foundation z 2016 r., które wykazały, że na 96,1\% dziewcząt uczęszczających do szkoły podstawowej jedynie 79,3\% kontynuowało naukę w szkole średniej ${ }^{63}$. W celu zniwelowania

62 J. Jiang, Women's Rights and Gender Equality in China. The Development and Struggle in Chains of State Feminism, „Handbook on Human Right in China" 2019, s. 8.

63 China Power, Do women in China face greater inequality than women 
różnic w dostępie do edukacji na terenach miejskich i wiejskich podejmowane są działania podnoszące jakość edukacji. W prowincji Syczuan, a także Ningxia i Gansu wprowadzono sale multimedialne, dzięki którym lekcje mogą być prowadzone online tak, aby zapewnić uczniom możliwość dzielenia się zasobami wiedzy ${ }^{64}$.

Dostęp do opieki zdrowotnej jest istotnym wyznacznikiem poziomu rozwoju społeczeństwa. Milenijne cele rozwoju przyjęte przez ONZ w 2000 r. miały na celu między innymi zmniejszenie liczby zgonów wśród dzieci i matek na całym świecie. Realizacja tych celów doprowadziła w Chinach do różnych inicjatyw, które znacznie zmniejszyły śmiertelność matek z 97 zgonów na 100 tys. urodzeń w 1990 r. do 27 zgonów w 2017 r. Warto zwrócić uwagę, że wskaźnik ten w rozwijających się dużych gospodarkach w 2017 r. wynosi np. dla Brazylii 44 zgony na 100 tys. urodzeń, a dla Indii aż 145 zgonów na 100 tys. urodzeń. Należy podkreślić, że istotne zmiany polityce zdrowotnej miały miejsce w 2006 r., kiedy to zdrowie zostało uznane przez chiński rząd za jeden z głównych priorytetów. Zainicjowano wówczas kompleksowe reformy służby zdrowia ${ }^{65}$. Następnie w latach 2001-2010 oraz na lata 2011-2020 powstał Krajowy Program Rozwoju Kobiet. Programy zwiększyły dostęp do usług w zakresie zdrowia, a przede wszystkich do badań profilaktycznych oraz edukacji zdrowotnej ${ }^{66}$. Należy zaznaczyć, że pomimo pozytywnych zmian w dziedzinie zdrowia Chiny wciąż borykają się zachwianą się równowagą płci. Według National Bureau Statistics of China

elsewhere?, https://chinapower.csis.org/china-gender-inequality/ [dostęp: 1.09.2019].

64 Ibidem.

65 W. Yip, W.C. Hsiao, The Chinese Health System At A Crossroads, „Health Affairs” 2008, nr 2, s. 463.

66 F. Zhao, China National Program for Women's Development (2011-2020), 2015, http://www.womenofchina.cn/womenofchina/html1/source/ 1502/998-1.htm [dostęp: 16.08.2019]. 
w 2017 r. współczynnik maskulinizacji wynosił 114,52 dla grupy wiekowej 0-4 lata, co oznacza, że już w momencie narodzin na 100 dziewczynek przypadało ponad 114 chłopców. Nienaturalna równowaga płci w Chinach została zachwiana przez restrykcyjną politykę jednego dziecka, połączoną z silną preferencją posiadania syna. Według ekspertów długotrwała nierównowaga płci spowodowała ponad 30-milionową nadwyżkę mężczyzn, co wiąże się ryzykiem negatywnych konsekwencji społeczno-ekonomicznych.

\section{Zakończenie}

Bez wątpienia chińskie kobiety zyskały większą autonomię w porównaniu do lat 50. XX w. Od czasów powstania Chińskiej Republiki Ludowej ustawodawstwo dotyczące praw kobiet jest regularnie ulepszane. Nastąpiły niezaprzeczalne postępy w dostępie do edukacji i usług zdrowotnych. Niestety chińskie kobiety wciąż pozostają daleko w tyle za mężczyznami na arenie politycznej. W dalszym ciągu mężczyźni mają większy dostęp do wykonywanych zawodów, co zwiększa ich status społeczno-ekonomiczny. Pod pozorem przepisów „chroniących” kobiety sprowadza się je do roli matek i żon. Tradycyjne postrzeganie ról płciowych zobowiązuje kobiety do pełnienia głównie obowiązków rodzinnych. Warto przypomnieć, że do niedawna pracodawcy dyskryminowali kobiety, zmuszając je do podpisania klauzuli zabraniającej im małżeństwa czy zajścia w ciążę. Wielu obserwatorów zwraca uwagę, że aktualna polityka planowania rodziny, promująca posiadanie dwójki dzieci również pogorszy sytuację kobiet na rynku pracy. W społeczeństwie, które przez stulecia utrzymywało, że miejsce kobiet jest w domu, prawa i szanse kobiet wciąż nie są równe. 


\section{Bibliografia}

Angeloff T., Lieber M., Equality Did You Say?, „China Perspectives 2012, nr 4.

Attané I., Tam, gdzie dzieci sa luksusem, Warszawa 2012.

Błaszczyk A., Sikora M., Kilka uwag o prawno-spotecznym statusie kobiet w Chińskiej Republice Ludowej, „Wrocławskie Studia Erazmiańskie" 2015, nr IX.

Burnett J., Women's Employment Rights in China, „Indiana Journal of Global Legal Studies" 2010, vol. 17.

Huang C., Why Low Political Participation of Rural Women in China: An Interpretation from Neo-Institutionalism Perspective, „Open Journal of Political Sciense” 2018, nr 8.

Jastrzębska E., Polityka genderowa Unii Europejskiej - geneza i ewolucja, „Kwartalnik Kolegium Ekonomiczno-Społecznego. Studia i Prace" 2014, nr 2.

Jiang J., Women's Rights and Gender Equality in China. The Development and Struggle i Chains of State Feminism, „Handbook on Human Right in China” 2019.

Li Y., Women's Movemnet and Change of Women's Status in China, „Journal of International Women's Studies” 2000.

Lipka A., Siostry Kopciuszka. O krępowaniu stóp w Chinach, „Loża Wschodu: 2012, nr 1 (2).

Ogletree Ch.J., When Gender Differences Become a Trap. The Impact of China's Labor Law and Women, "Yale Journal of Law and Feminism" 2002.

Piotrowska J., Siekiera A., Sznajder A., Jak realizować zasadę równości szans kobiet i mężczyzn, Warszawa 2016.

Rachwaniec-Szczecińska Ż., Synowie jedynacy i znikajace córki - o pozycji kobiet w Chinach, „Pisma Humanistyczne” 2013, nr 9.

Stowell J.A., The Influence of Cnfucian Values on Interpersonal Communication in South Korea, as Compared to China 
and Japan, „Intercultural Communication Studies” 2003, nr XII-4.

Tomala K., Planowanie rodziny warunkiem modernizacji kraju, [w:] Chiny. Przemiany państwa i społeczeństwa w okresie reform 1978-2000, red. K. Tomala, Warszawa 2003.

Yife S., Feminism in China, An Analysis of Advocates, Debates and Strategies, "Counntry Study, Friedrich Ebert Stiftung” 2016.

Yip W., Hsiao W.C., The Chinese Health System At A Crossroads, „Health Affairs” 2008, nr 2.

\section{Źródla internetowe}

A Brief Report on the Combined Seventh and Eighth Periodic Report Submitted by China under Article 18 of the Convention on the Elimination of All Forms of Discrimination against Women.

Cedaw the $66^{\text {th }}$ Session, https://www.soroptimistinternational. org/cedaw-66th-session/.

China Power, Do women in China face greater inequality than women elsewhere?, https://chinapower.csis.org/china-gender-inequality/.

Convention on the Elimination of All Forms of Discrimination against Women New York, 18, Country Briefing Paper, Women in the People's Republic of China, 1992, https://www. adb.org/sites/default/files/institutional-document/32565/ women-peoplesrepublic-china.pdf.

December 1979, https://www.ohchr.org/en/professionalinterest/pages/cedaw.aspx.

Gender Equality and Women's Development in China, http:// www.china-un.ch/eng/rqrd/jblc/t210715.htm.

Green Dorros S., The Status of Women in the People's Republic of China, https://www.asj.upd.edu.ph/mediabox/archive/ ASJ-16-1978/dorros-women-china.pdf. 
Inquiry into access to contraception in Manila: CEDAW Committee finds that the Philippines violated CEDAW, https:// opcedaw.wordpress.com/category/cedaw-article/cedaw-ar$\mathrm{t}-161 \mathrm{e} /$.

Human Rights Brief, Women in China, https://www.refworld. org/docid/3ae6a81020.html.

Jonczy-Adamska M., Pteć kulturowa - stownik, https://rownosc.info/dictionary/pec-kulturowa/.

Koetse M., How the One - Child Policy Has Improved Women's Status in China, https://www.whatsonweibo.com/ one-child-policy-improved-womens-status-china/.

Rincon R., Gender Discrimination in China, 2018, https://alltogether.swe.org/2018/04/gender-discrimination-in-china/. Traditional Women's Roles in China, http://factsanddetails. com/china/cat3/sub9/entry-5562.html\#chapter-1.The Global Gender GAP Report 2018 s.16,http://www3.weforum. org/docs/WEF_GGGR_2018.pdf.

UNDP, Goal 5: Geneder Equality, https://www.sdfinance.undp. org/content/sdfinance/en/home/sdg/goal-5--gender-equality.html.

UN Woman, Women gain political representation and Leadership in rural China, 2016, https://www.unwomen.org/en/ news/stories/2016/9/women-gain-political-representation-and-leadership-in-rural-china.

United Nations Population Found, Frequently asked questions about gender Equality, 2005, https://www.unfpa.org/resources/frequently-asked-questions-about-gender-equality

Webster F., Rosseau S., China Strngthens Gender Equality, https://www.mercer.com/our-thinking/law-and-policy-group/china-strengthens-gender-equality.html.

Xiaobing Z., The Ratyfication an Implementation of CEDAF in China, 2017, http://www.chinahumanrights.org/ html/2017/MAGAZINES_0504/7976.html. 
Zhao F., China National Program for Women's Development (2011-2020), 2015, http://www.womenofchina.cn/womenofchina/html1/source/1502/998-1.htm.

https://tbinternet.ohchr.org/Treaties/CEDAW/Shared\%20Documents/CHN/INT_CEDAW_NGO_CHN_18130_E.pdf.

\begin{abstract}
Abstrakt
Równość płci i prawa kobiet, w tym ich wzmocnienie oraz rozwój odgrywają istotną rolę w budowaniu wzrostu społeczno-ekonomicznego we wszystkich rozwijających się państwach. Problem dyskryminacji ze względu na płeć jest problemem globalnym i pomimo znacznych postępów w tym zakresie wciąż tam, gdzie występują nierówności, to na ogół kobiety są dyskryminowane ze względu na płeć. Celem niniejszego artykułu jest odpowiedź na pytanie w jaki sposób realizowana jest polityka równościowa w Chinach, szczególnie w wybranych, kluczowych dla tejże polityki aspektach, tj. edukacja, praca zawodowa, udział kobiet w życiu politycznym oraz dostęp do usług zdrowotnych.
\end{abstract}

Słowa kluczowe: polityka równościowa, Chiny, prawa kobiet, równouprawnienie, kobiety w Chinach

\begin{abstract}
Gender equality and women's rights, including their strengthening and development, play an important role in building socioeconomic growth in all developing countries. The problem of discrimination based on sex is a global problem and despite significant progress in this area, there are still women where there are inequalities are discriminated against on grounds of sex. The purpose of this article is to answer the questions how equality policy is implemented in China, especially in selected aspects that are key to this policy, i.e. education, professional work, women's participation in political life and access to health services.
\end{abstract}

Keywords: equality policy, China, women's rights, equality, women in China 


\author{
Agnieszka Magdalena Kociemba \\ Kancelaria Komornilka Sądowego przy Sądzie Rejonowym \\ Szczecin-Centrum w Szczecinie \\ ORCID ID: https://orcid.org/0000-0002-6358-6382
}

\title{
Prawa kobiet w Turcji. Omówienie wybranych aspektów
}

\section{Wstęp}

We współczesnym świecie nie budzi wątpliwości, że wolności i prawa człowieka stały się przedmiotem kompleksowych regulacji prawnych. Należy jednak mieć na uwadze, że fakt spisania i usankcjonowania ochrony prawnej jednostki w aktach normatywnych zarówno międzynarodowych, jak i krajowych nie zawsze jednak eliminuje zjawisko patologii. Nie wszędzie normy prawne w zakresie praw człowieka pomimo ich zapisania w prawodawstwie danego kraju są przestrzegane, a w przypadku naruszeń karane.

W niniejszym artykule autorka chce nakreślić zagadnienie jakim jest prawo kobiet w Turcji, ze szczególnym uwzględnieniem jego naruszeń oraz aspektu małżeństwa. Według autorki jednym z najpoważniejszych wyzwań przed jakimi stoi Turcja, zwłaszcza ze względu na toczący się proces akcesyjny do UE, jest przestrzeganie przez społeczeństwo prawa w zakresie praw kobiet. Autorka postara się w niniejszym artykule odpowiedzieć na takie pytania, jak: Czy prawa kobiet w Turcji są respektowane?; Jaki wpływ na życie kobiety w Turcji ma małżeństwo?; Czy zapewnienie ochrony prawnej kobietom ma wpływ na proces akcesyjny Turcji do Unii Europejskiej? Autorka zdaje sobie jed- 
nocześnie sprawę z tego, że tematyka praw kobiet w Turcji jest bardzo złożona i wielowątkowa; celem autorki jest wyselekcjonowanie wybranych zagadnień i poddanie ich analizie.

Turcja (Republika Turcji) położona jest na dwóch kontynentach, jednak jej część europejska stanowi jedynie 3\% ogólnej powierzchni kraju. Część europejską od azjatyckiej dzieli Morze Marmara i cieśniny Bosfor i Dardanele. Państwo tureckie jest mocno zakorzenione zarówno w Europie, jak i Azji i powinno być to atutem wykorzystywanym do odgrywania wielopłaszczyznowej roli pośrednika między Wschodem i Zachodem. Turcja jest w 99\% państwem muzułmańskim, w którym przeważają sunnici. Jako jedyne państwo z większością muzułmańskich obywateli Turcja nie jest państwem wyznaniowym, jednak tradycje i obyczaje odgrywają kluczową rolę w życiu zamieszkujących ją społeczności ${ }^{1}$.

Często w literaturze możemy się spotkać z podziałem na Turcję „zachodnią" - bardziej postępową, dążącą do standardów europejskich systemów wartości oraz Turcję wschodnią, gdzie głęboko zakorzenione jest tradycyjne pojmowanie systemu wartości. Niewątpliwie w dzisiejszych czasach duża ilość Turczynek decyduje sama o sobie, podobnie jak przeciętna Europejka, ale wciąż pozostaje pewna grupa kobiet, która jest ubezwłasnowolniona przez tradycyjne zależności społeczne i rodzinne. Za głowę tureckiej rodziny uznaje się mężczyznę, kobieta występuje w roli nosicielki honoru dla całego rodu. W Turcji panuje typowo patriarchalny model rodziny. Kobieta od chwili urodzenia, aż do momentu śmierci jest pod opieką męskiego członka rodziny. Na początku pieczę nad dziewczynką sprawuje jej ojciec, z biegiem czasu odpowiedzialność za kobietę przejmują bracia, a po ślubie mąż i synowie.

1 L. Büyükbayrar, Matżeństwo w Turcji - wybrane aspekty, [w:] Bliski Wschód w procesie przemian, red. A. Bryc, M. Dahl, M. Lewicka, Toruń 2015, s. 165. 


\section{Patriarchalny model rodziny a sytuacja kobiet w Turcji}

Zanim Turcja przyjęła islam kobiety traktowane były z należytym szacunkiem, posiadały szeroki zakres praw w sferze społecznej i politycznej. Lud turecki przyjął islam w IX w., nadal pozostając wierny swoim obyczajom. Jednak z czasem nowa religia wprowadziła zmiany w życiu Turków. W czasach kalifa Omara kobiety używały krótkiej woalki, ale już w okresie Imperium Osmańskiego od XIV w. do początku XX w. kobiety miały ograniczony dostęp do edukacji i poddawano je coraz ostrzejszym rygorom. Życie haremowe zostało wprowadzone do tureckich pałaców w XV w., a poligamia stała się faktem. Jednakże maksymalnie jednocześnie można było mieć cztery żony. W prawie rodzinnym u Osmanów kobieta nie miała nic do powiedzenia przy wyborze mężczyzny. Męża wybierali kobiecie rodzice lub jeden z najstarszych członków rodziny. Oficjalnych zaręczyn nie organizowano, przybierały one najczęściej formę prywatnej umowy między dwiema rodzinami. Zgodnie $\mathrm{z}$ islamem małżeństwo było zawierane w obecności świadków i za zgodą obu stron ${ }^{2}$.

Kolejny etap zmian dla kobiet w sferze prawno-obyczajowej nastąpił za czasów rządów Atatürka. Przywódca zarządził równouprawnienie. Od 1925 r. kobiety w Turcji zyskały przywileje, mogą m.in. studiować, pracować oraz zajmować kierownicze stanowiska. W 1924 r. utworzono pierwszą szkołę muzyczną dla nauczycieli, która w 1936 r. stała się dostępna dla kobiet. W 1928 r. pierwsza kobieta stała się członkinią tureckiej Izby Adwokackiej. Prawdziwy przełom nastąpił w 1924 r., kiedy kobiety otrzymały prawa wyborcze. Dziesięć lat później umożli-

2 M. Kiebała, Kobieta w prawie tureckim, http://www.politykaglobalna. pl/2009/03/kobieta-w-prawie-tureckim/ [dostęp: 11.05.2019]. 
wiono im kandydowanie do parlamentu ${ }^{3}$. Bardzo ważnym aktem prawnym przyjętym w 1926 r., który jako pierwszy miał istotne znaczenie dla poprawy sytuacji kobiet w Turcji był Kodeks cywilny z 17 lutego 1926 r. Kodeks podkreślał równość praw kobiet i mężczyzn oraz jawne oddzielenie sfery prawnej od islamu. Jak ważny był okres przemian prawnych i społecznych ery Atatürka najlepiej obrazują słowa samego Kemala z dnia 12 kwietnia 1935 r. wypowiedziane do uczestników Międzynarodowego Kongresu Kobiet w Stambule: „Jestem przekonany, że korzystanie z praw społecznych i politycznych przez kobiety jest niezbędne do szczęścia i dumy ludzkości. Możecie mieć pewność, że tureckie kobiety, wraz z kobietami z całego świata, będa działać na rzecz pokoju i bezpieczeństwa na świecie"

Ważnym momentem dla tureckiej społeczności w kwestii praw kobiet oraz bardzo tradycyjnego podejścia do wyglądu kobiet był 1999 r. Od tego momentu Turczynki nie mogą nosić chust w urzędach publicznych oraz na państwowych kampusach uniwersyteckich. Ten zakaz został wprowadzony po wystąpieniu Merve Kavacki, która podczas przysięgi składanej w parlamencie miała na głowie chustę. Należy jednak podkreślić, że zakaz ten wprowadzono na tureckich uniwersytetach już od lat 80., jednakże nie wszędzie był respektowany.

Jak wspomniano powyżej w społeczności tureckiej wciąż możemy zaobserwować patriarchalny model rodziny, na który niewątpliwie ogromny wpływ ma religia. Tradycyjny model rodziny charakteryzuje się przede wszystkim silną władzą mężczyzny, podporządkowaniem starszym oraz określonymi wzorcami obyczajowymi dla mężczyzn i kobiet. Kobieta w islamie od pierwszych dni swojego życia traktowana jest jako istota bezbronna słaba, a co za tym idzie wymagająca opieki

3 Ibidem.

4 M.K. Atatürk, Women's Rights, http://ataturk.twoday.net/topics/ Women's+Rights/ [dostęp: 11.05.2019]. 
mężczyzny. Sprawowanie opieki jest bardzo szeroko rozumiane. Sytuacja kobiet zmienia się, gdy wychodzą one za mąż. Opiekę nad taką kobietą przejmuje mąż. Kobiety w Turcji są od początku wychowywane i przygotowywane do pełnienia roli dobrej żony i matki. Prestiż kobiety w rodzinie rośnie wraz z wiekiem oraz urodzeniem kolejnych synów.

\section{Najważniejsze akty prawne regulujące prawa kobiet w Turcji}

Do najważniejszych aktów prawnych w Turcji, których przepisy mają na celu ochronę prawną kobiet zaliczamy w pierwszej kolejności: Konstytucję Republiki Tureckiej, Kodeks cywilny, Kodeks karny.

Obecnie obowiązująca Konstytucja Republiki Tureckiej z 1982 r. jest najobszerniejszą ustawą zasadniczą w historii Republiki Turcji. Konstytucja składa się z 177 artykułów regulujących w sposób szczegółowy, często nawet kazuistyczny, kwestie polityczne i społeczne. W ustawie zasadniczej aż 63 spośród 177 przepisów traktuje o prawach i obowiązkach jednostki. Regulacje te mają jednak charakter norm bardziej deklaratoryjnych, aniżeli faktycznie stosowanych.

Ogromny wpływ na zmiany w prawie tureckim ma fakt, że Turcja uczestniczy w procesie akcesyjnym do Unii Europejskiej, a zadbanie o ochronę prawną kobiet jest jednym podstawowych warunków jakie musi spełnić, aby stać się członkiem wspólnoty. Do najważniejszych aktów prawnych w tym zakresie należy zaliczyć:

- rezolucję Parlamentu Europejskiego z dnia 6 lipca 2005 r. w sprawie roli kobiet w życiu społecznym, gospodarczym i politycznym Turcji (2004/2215 ( INI) $)^{5}$;

5 Rezolucja Parlamentu Europejskiego w sprawie roli kobiet w życiu 
- rezolucję Parlamentu Europejskiego z dnia 27 września 2006 r. w sprawie roli kobiet w życiu społecznym, gospodarczym i politycznym Turcji (2006/2214(INI)) ${ }^{6}$;

- rezolucję Parlamentu Europejskiego z dnia 22 maja 2012 r. w sprawie przyszłości kobiet w Turcji do 2020 r. $(2011 / 2066(\mathrm{INI}))(2013 / \mathrm{C} 264 \mathrm{E} / 05)^{7}$.

\section{Naruszenia praw kobiet}

W swojej monografii Między islamem a kemalizmem. Problem demokracji w Turcji A. Szymański wyróżnia następujące sfery w których dochodzi do naruszeń praw kobiet. Pierwsza sfera związana jest z rodziną i małżeństwem, druga dotyczy stosowania przemocy wobec kobiet, trzecia zaś dotyka równouprawnienia kobiet i mężczyzn w życiu społeczno-politycznym ${ }^{8}$. Z uwagi na złożoność zagadnienia i fakt, iż każdy z wyżej wymienionych sfer naruszeń mogłaby stanowić osobny problem badawczy autorka omówi jedynie wybrane aspekty i zasygnalizuje rozwój prawodawstwa tureckiego mający na celu ochronę praw kobiet w wyżej wymienionych sferach.

społecznym, gospodarczym i politycznym Turcji ( 2004/2215 (INI)) z dnia 6 lipca 2005 r., oficjalna strona Parlamentu Europejskiego, http://www.europarl.europa.eu/sides/getDoc.do?pubRef=//EP//TEXT+TA+P6-TA-20050287+0+DOC+XML+V0//PL [dostęp: 10.05.2019].

6 Rezolucja Parlamentu Europejskiego z dnia 27 września 2006 r. $\mathrm{w}$ sprawie roli kobiet $\mathrm{w}$ życiu społecznym, gospodarczym politycznym Turcji (2006/2214(INI)), oficjalna strona Parlamentu Europejskiego, http://www. europarl.europa.eu/news/pl/search?planet=_all\&q=Rezolucja + Parlamen$\mathrm{tu}+$ Europejskiego $+\mathrm{w}+$ sprawie+roli + kobiet $+\mathrm{w}+\% \mathrm{C} 5 \% \mathrm{BCyciu}+\mathrm{spo} \% \mathrm{C} 5 \% 82 \mathrm{ecz}-$ nym $\% 2 C+$ gospodarczym $+i+$ politycznym + Turcji+\% $282006 \% 2$ F $2214 \% 2-$ 8INI\%29\%29 [dostęp: 10.05.2019].

7 Rezolucja Parlamentu Europejskiego z dnia 22 maja 2012 r. w sprawie przyszłości kobiet w Turcji do 2020 r. (2011/2066(INI)) (2013/C 264 E/05), https://eur lex.europa.eu/legal content/PL/TXT/PDF/?uri=CELEX:52012IP0212\&from=RO [dostęp: 10.05.2019].

8 Por. A. Szymański, Między islamem a kemalizmem. Problem demokracji w Turcji, Warszawa 2008, s. 148-164. 


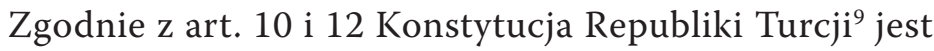
gwarantem równość wszystkich ludzi. Stanowi również, że żadna osoba, rodzina, grupa czy klasa społeczna nie ma pozycji uprzywilejowanej. Konstytucja gwarantuje wszystkim obywatelom nieograniczony dostęp do edukacji, nauczania, prawa do wyrażania własnych poglądów oraz swobodę przemieszczania się.

Jako pierwszy problem związany z naruszeniem praw kobiet i dyskryminacją autorka wskazuje ograniczenie zatrudnienia wśród kobiet. Nie mogą one pracować w kopalniach, przy układaniu kabli, budowaniu tuneli oraz przy innego rodzaju pracach podziemnych i podwodnych. Przełomowym dla kobiet w kwestii rozpoczęcia kariery zawodowej oraz jej rozwoju był 1994 r. Od tego momentu żona nie potrzebuje pozwolenia męża na podjęcie pracy poza domem. Jest to bardzo ważny element pozwalający kobietom na niezależność finansową, co niekiedy stanowi podstawę podejmowania kluczowych życiowych decyzji. Jednak rzeczywistość w sferze pracy zarobkowej oraz niezależności finansowej kobiet nie wygląda dobrze. W Turcji 88\% bezrobotnych stanowią kobiety. Patriarchalny model rodziny

9 Art. 10 Wszyscy są równi wobec prawa bez względu na język, rasę, kolor skóry, płeć, poglądy polityczne i przekonania filozoficzne, religię, wyznanie bądź inne względy. Kobieta i mężczyzna mają równe prawa. Państwo jest obowiązane zagwarantować wprowadzenie tej zasady w życie. Podejmowane w tym celu kroki nie mogą być interpretowane jako sprzeczne z zasadą równości wobec prawa. Kroki podejmowane dla zapewnienia szczególnej ochrony dzieciom, osobom starszym i osobom niepełnosprawnym oraz wdowom i sierotom po poległych lub zmarłych w trakcie służby, a także inwalidom i weteranom, nie są traktowane jako sprzeczne z zasadą równości wobec prawa. Art. 11 Nie przyznaje się przywilejów żadnej jednostce, rodzinie, grupie czy klasie. Organy państwowe i władze administracyjne mają obowiązek przestrzegania zasady równości wobec prawa we wszystkich swoich działaniach. Art. 12 Każdemu przysługują przyrodzone, nienaruszalne i niezbywalne podstawowe prawa i wolności. Podstawowe prawa i wolności wiążą się z odpowiedzialnością i obowiązkami jednostki wobec społeczeństwa, rodziny i innych jednostek, [w:] Konstytucja Republiki Tureckiej, red. W. Staśkiewicz, K. Gralak, Warszawa 2017, s. 8-10. 
często wymusza na kobiecie pozostanie w domu i poświęcenie się rodzinie.

Jedną ze znaczących zmian w prawie tureckim było wprowadzenie zakazu przeprowadzania testów dziewictwa wśród dziewcząt w szkołach średnich, kobiet kandydujących na stanowiska rządowe oraz pacjentek szpitali. W 1994 r. pięć dziewcząt usiłowało popełnić samobójstwo w proteście przeciwko testom dziewictwa. Na kanwie tego przypadku dopiero wówczas władze zdecydowały się ich zakazać. Jednakże prawo nadal dopuszcza test dziewictwa dla celów dowodowych. Testy były i często jeszcze są formą poniżenia lub kary. Kobietom, u których stwierdzono brak błony dziewiczej grożą straszne konsekwencje, takie jak: przemoc, poniżanie, a w skrajnych przypadkach nawet śmierć. Rodzina badanej miała pełny dostęp do wyników przeprowadzonego testu. Sama obawa przed testem może być wystarczająca, aby spowodować konsekwencje psychologiczne dla ofiary ataku seksualnego. Odmowa poddania się testowi może być postrzegana jako przyznanie się do „splamienia honoru" i skutkować kolejnym atakiem seksualnym ${ }^{10}$.

W opinii autorki jednak najpoważniejszymi naruszeniami praw kobiet są: zbrodnie honorowe, przemoc $\mathrm{w}$ rodzinie oraz zawieranie małżeństw z nieletnimi. Pomimo konstytucyjnych gwarancji, które mówią o równości i wolności wciąż w Turcji mamy do czynienia z przemocą w rodzinie.

W Turcji, formalnie biorącej udział w procesie akcesyjnym do UE i która kreuje swój wizerunek jako państwo muzułmańskie a jednocześnie laickie, w której respektowane są na równi prawa kobiet i mężczyzn rokrocznie giną kobiety oraz dziewczęta. Giną na skutek przemocy domowej, która przybiera różne formy (seksualną, fizyczną, psychiczną). Brak reakcji społeczeń-

10 M. Kiebała, Kobieta w prawie tureckim, http://www.politykaglobalna. pl/2009/03/kobieta-w-prawie-tureckim/ [dostęp: 11.05.2019]. 
stwa oraz milcząca zgoda na akty przemocy potęguje to zjawisko.

Organizacja pozarządowa Platforma Zatrzymamy Zabijanie Kobiet podaje, że tylko w 2016 r. zabito 328 kobiet, a sprawcami byli głównie mężowie czy partnerzy. Raport Federacji Stowarzyszeń Kobiet Tureckich podaje liczbę 261 zamordowanych. Różnica w danych wynika z tego, że państwo tureckie nie prowadzi żadnych statystyk. Stowarzyszenia kobiece same ustalają liczby, głównie na podstawie informacji medialnych oraz nielicznych przypadków zgłaszających się do nich kobiet ${ }^{11}$.

W Turcji od 1998 r. obowiązuje prawo przeciwko przemocy w rodzinie (tzw. prawo numer 4320) jednak mimo to problem przemocy w rodzinie nie maleje. Zgodnie z tymi przepisami przeciwko przemocy w rodzinie ofiara nie musi występować jako strona procesu, oskarżenie może wnieść również członek rodziny, przyjaciel, sąsiad lub prokurator. Wniesienie pozwu nie wymaga opłaty sądowej. Sprawa dotycząca przemocy w rodzinie trafia do sądu pokoju. Po wpłynięciu pozwu do sądu, sędzia orzeka środki zapobiegawcze, jakie należy zastosować wobec oskarżonego. Takimi środkami są:

- zakaz przebywania w miejscu zamieszkania poszkodowanego;

- zakaz zbliżania się do ofiary przemocy domowej;

- zakaz niszczenia mienia należącego do poszkodowanego (niszczenie mienia współmałżonka lub dziecka przed zastosowaniem takiego środka nie jest przestępstwem w świetle prawa);

- poinformowanie pracodawcy o zachowaniu pracownika - sprawcy przemocy domowej ${ }^{12}$.

11 E. Orhan, Być kobietą w Turcji, https://www.tygodnikprzeglad.pl/ byc-kobieta-turcji/ [dostęp: 11.05.2019].

12 M. Kiebała, Kobieta w prawie tureckim, http://www.politykaglobalna. pl/2009/03/kobieta-w-prawie-tureckim/ [dostęp: 11.05.2019]. 
Powyżej wymienione środki zapobiegawcze mogą być orzeczone na okres do sześciu miesięcy. Jeżeli środki zapobiegawcze nie przynoszą zamierzonego efektu, a sprawca popełnianych czynów ponownie dopuszcza się naruszeń prawa zostaje on aresztowany i toczy się przeciwko niemu postępowanie karne, które prowadzi do wydania wyroku skazującego.

Rewolucją w tureckim Kodeksie karnym była zmiana z dnia 26 września 2004 r., od kiedy to przestępstwa na tle seksualnym kwalifikowane jako przestępstwa przeciwko społeczeństwu, moralności publicznej i rodzinie zaczęto kwalifikować jako przestępstwo gwałtu. Wprowadzony został również zakaz rozróżniania gwałtu na kobietach zamężnych oraz niezamężnych. Uprzednio gwałt na kobiecie niezamężnej był karany surowiej niż gwałt na kobiecie zamężnej. Za przestępstwo uznany został również gwałt małżeński (jako przestępstwo ścigane z oskarżenia prywatnego). Przestępstwa seksualne, których ofiarami są dzieci poniżej 15. roku życia zostały uznane za oddzielny rodzaj przestępstwa. Kodeks karny po zmianach wprowadził definicję kolejnego przestępstwa jakim jest zabójstwo honorowe.

Według raportu Human Rights Watch „zbrodnia honorowa” jest „aktem przemocy, zazwyczaj morderstwem, popełnianym przez członka rodziny przeciwko drugiemu członkowi rodziny, który postrzegany jest jako osoba, która przyniosła hańbę rodzinie"13.

Najczęstszymi powodami zabójstw na tle honorowym są:

- związek pozamałżeński;

- problemy związane z poligamią (pomimo że poligamia

13 Item 12 - Integration of the human rights of women and the gender perspective: Violence Against Women and "Honor" Crimes Human Rights Watch Oral Intervention at the $57^{\text {th }}$ Session of the UN Commission on Human Rights, https://www.hrw.org/news/2001/04/05/item-12-integration-human-rights-women-and-gender-perspective-violence-against-women [dostęp: 11.05.2019]. 
jest zakazana przez prawo często występuje na obszarach wiejskich);

- presja rodziny na zawarcie małżeństwa z wybraną przez rodzinę osobą - porwanie i gwałt żony;

- małżeństwo rozwiedzionej kobiety z mężczyzną z otoczenia byłego męża (krewny, przyjaciel);

- presja społeczno-kulturowa wywierana na mężczyzn ${ }^{14}$.

Raport Human Rights wskazuje, że w latach 2006-2007 dokonano 370 zbrodni powiązanych z kategorią zabójstw honorowych. Dokonano ich głównie w rejonie Marmara oraz Anatolii. Human Rights donosi, że ofiary pochodzą najczęściej z rodzin ortodeksyjnych i są to nie tylko kobiety, ale również mężczyźni, brak jednak dokładnych danych statystycznych na ten temat. Napastnikami są najczęściej mężczyźni, ale zdarzają się również kobiety (starsze przedstawicielki rodu matki, teściowe). Wśród ofiar zdecydowaną większość stanowią kobiety. Zabójstwo honorowe popełniają najczęściej mężczyźni w wieku 19-35 lat, co zaprzecza powszechnemu poglądowi, że zabójstw tych dokonują najmłodsi (jedynie 9\%). Przez długie lata organizacje walczące o prawa kobiet postulowały penalizację tych przestępstw ${ }^{15}$.

W raporcie The Dynamics of the honour killings in Turkey z 2007 r. ${ }^{16}$ szczegółowo zaprezentowano przyczyny zabójstw honorowych, przedstawiono sposób postrzegania honoru przez kobiety i mężczyzn w Turcji. W raporcie wskazano powody, dla których dokonuje się zbrodni honorowych. Badania przeprowadzone wśród respondentów narodowości tureckiej

14 M. Kiebała, Kobieta w prawie tureckim, http://www.politykaglobalna. pl/2009/03/kobieta-w-prawie-tureckim/ [dostęp: 11.05.2019].

15 Ibidem.

16 UNDP, Population Association, UNFPA, The Dynamics of the honour killings in Turkey, https://www.unfpa.org/publications/dynamics-honour-killings-turkey, 2007 [dostęp: 9.05.2019]. 
pochodzących z różnych grup społecznych wykazały, że honor pojmowany jest przez nich w sposób bardzo tradycyjny. W opinii badanych głównie ze wschodniej i południowej części kraju każde wykroczenie przeciwko honorowi powinno być karane śmiercią.

Niezależnie od stanowiska władz i od rozbieżności danych przytaczanych przez organizacje kobiece faktem jest, że kobiety w Turcji giną albo są ofiarami przemocy zbyt często ze zbyt błahych powodów. Mężczyźni mimo sankcji karnych nadal zabijają je w imię honoru. Wiele kobiet, które nie poniosły śmierci pada ofiarą przemocy fizycznej, seksualnej, psychicznej. Według danych Ministerstwa Rodziny i Polityki Społecznej co czwarta kobieta doświadcza przemocy fizycznej oraz seksualnej, $89 \%$ kobiet nie zgłasza się po pomoc do żadnej instytucji ${ }^{17}$.

Za moment zwrotny w zwalczaniu zjawiska zabójstw honorowych należy uznać precedensowy wyrok wydany 13 stycznia 2009 r. w sprawie Naile Erdas, szesnastoletniej dziewczyny, która zaszła w ciążę w wyniku gwałtu i została zamordowana przez swoją rodzinę. Członkowie rodziny zostali skazani na karę dożywotniego pozbawienia wolności.

Problem zbrodni honorowych i przemocy w rodzinie nie zostanie wyeliminowany nawet przy użyciu najlepiej skonstruowanych norm prawnych, gdyż bez konkretnych działań pozostaną one tylko pustymi normami. Problemy te będą istnieć dopóki nie zostanie przekształcona patriarchalna struktura społeczeństwa, dopóki nie będzie faktycznej równości płci w sferze ekonomicznej, gospodarczej, społecznej oraz politycznej.

17 E. Orhan, Być kobietą w Turcji, https://www.tygodnikprzeglad.pl/ byc-kobieta-turcji/ [dostęp: 11.05.2019]. 


\section{Małżeństwo w Turcji}

Małżeństwo dla każdej Turczynki i każdego Turka jest jednym z najważniejszych momentów w życiu. Zgodnie z obowiązującymi zasadami społecznymi w Turcji oraz zasadami islamu małżeństwo stanowi obowiązek każdego mężczyzny, który ma predyspozycje do utrzymania rodziny.

Zgodnie z definicją słownikową „Małżeństwo, regulowany przez prawo trwały związek kobiety i mężczyzny zawarty w celu wspólnego pożycia, wzajemnej pomocy i współdziałania dla dobra założonej rodziny, a zwłaszcza wychowania dzieci”18.

$Z$ powyższej definicji należy wnioskować, że ceremonia zawarcia małżeństwa jest niezwykle istotna nie tylko dla nowożeńców, ale również dla całego społeczeństwa; ma usankcjonować związek między dwojgiem ludzi. $Z$ definicji tej wynika również kolejny bardzo istotny fakt jakim jest prokreacja, a co za tym idzie nastawienie kobiety do pełnienia przez nią roli matki.

Podczas obrządku ślubno-weselnego w Turcji można wyszczególnić następujące etapy:

- poznanie się młodych,

- zaręczyny,

- ślub (cywilny),

- wesele,

- noc poślubna (często ślub religijny jest odprawiany w domu zaraz po powrocie młodej pary z uroczystości weselnych ${ }^{19}$.

Odnosząc się do kwestii samego ślubu małżeństwo nie jest aktem religijnym, jest to kontrakt między narzeczonymi i ich

18 https://encyklopedia.pwn.pl/haslo/malzenstwo;4011433.html [dostęp: 11.05.2019 r.].

19 L. Büyükbayrar, Matżeństwo w Turcji - wybrane aspekty, [w:] Bliski Wschód w procesie przemian, red. A. Bryc, M. Dahl, M. Lewicka, Toruń 2015, s. 172. 
rodzicami. Do zawarcia małżeństwa dochodzi przy świadkach przed osobą będąca reprezentantem władzy - urzędnikiem miejskim, który dokumentuje zawarcie małżeństwa. Ślub religijny nie ma mocy prawnej.

Zgodnie z regulacjami dotyczącymi zawarcia małżeństwa, kobieta może wyjść za mąż, gdy spełnia następujące warunki:

- stan psychiczny pozwalający na zawarcie małżeństwa (np. choroba psychiczna jest przeszkodą);

- ukończony 18. rok życia (zmiana art. 124 Kodeksu cywilnego), a w przypadku nadzwyczajnym sędzia może wyrazić zgodę na zawarcie małżeństwa przez 17-letnią dziewczynę (zmiana art. 124), wcześniej już 14-letnia dziewczyna mogła wyjść za mąż;

- mężczyzna może ożenić się, gdy skończy 18 lat, a w nadzwyczajnych przypadkach, gdy skończy 17 ;

- zakazane jest małżeństwo pomiędzy krewnymi;

- obowiązuje okres oczekiwania - kobiety, których małżeństwo zostało rozwiązane nie mogą wyjść ponownie za mąż wcześniej niż po trzechsetnym dniu od rozwodu. Ten zapis jest obecnie przedmiotem dyskusji ${ }^{20}$.

Przy zawarciu małżeństwa należy przedłożyć niezbędne dokumenty, takie jak: dowód osobisty, paszport, akt urodzenia, certyfikat zdrowia, cztery zdjęcia (pana i panny młodej), a także zaświadczenie, że dana osoba nie pozostaje w innym związku małżeńskim.

Zgodnie z art. 41 Konstytucji, który to został zmieniony w 2002 r. prawo tureckie zakłada, że małżeństwo opiera się na równej pozycji męża i żony ${ }^{21}$. Cywilna uroczystość przepro-

20 M. Kiebała, Kobieta w prawie tureckim, http://www.politykaglobalna. pl/2009/03/kobieta-w-prawie-tureckim/ [dostęp: 11.05.2019].

21 Art. 41 Rodzina będąca podstawą tureckiego społeczeństwa oparta jest na równouprawnieniu małżonków, [w:] Konstytucja Republiki Tureckiej, red. W. Staśkiewicz, K. Gralak, Warszawa 2017, s. 25. 
wadzana przez urzędnika trwa bardzo krótko, często urzędnik ma już przygotowany akt małżeństwa. Urzędnik odczytuje narzeczonym ich prawa i obowiązki pojawiające się w związku z wejściem w związek małżeński, następnie pyta ich o zgodę na zawarcie małżeństwa, na koniec narzeczeni składają stosowne podpisy, a urzędnik ogłasza ich małżeństwem. Ceremonia zaślubin po dokonaniu zmian art. 134 tureckiego Kodeksu cywilnego może odbyć się w miejscu zamieszkania zarówno pana młodego, jak i panny młodej. Uprzednio mogła odbywać się tylko w miejscu zamieszkania pana młodego. W zależności od regiony zamieszkania małżonków ceremonie mają charakter tradycyjny obrzędów (wschód kraju) lub nabierają coraz bardziej europejskiego charakteru. Po zawarciu małżeństwa każdy z małżonków ma prawo zgodnie z obowiązującym prawem rozporządzać majątkiem wspólnym. Zarówno mąż, jak i żona są w równym stopniu odpowiedzialni za zobowiązania finansowe współmałżonka. Zgodnie z tureckim prawem cywilnym możliwe jest spisanie intercyzy. Kobieta ma prawo do zachowania swojego nazwiska panieńskiego, a mąż może przyjąć nazwisko panieńskie żony. W kraju, gdzie religią dominującą jest islam nie sposób nie wspomnieć o poligamii. Koran wyraża zgodę na poligamię, jednak normy prawa stanowionego w Turcji (Kodeks cywilny) zakazują tego typu praktyki.

Zakończenie małżeństwa w Turcji może nastąpić na dwa sposoby. Pierwszy występuje z przyczyn naturalnych - śmierć małżonka, drugi zgodnie z obowiązującymi przepisami prawa w skutek rozwodu małżonków.

Śmierć małżonka wiąże się z dziedziczeniem majątku. Generalną zasadą jest, że żona dziedziczy $1 / 4$ spadku, a dzieci 3/4. W przypadku, gdy mąż umarł bezpotomnie i nie miał krewnych, żona dziedziczy cały majątek. W przypadku, gdy żyją krewni, połowę spadku dziedziczy żona, a połowę krewni zmarłego. Jeżeli mąż spisze testament i zastrzeże, że cały spadek zosta- 
wia żonie, to rodzice zmarłego mogą dochodzić $1 / 4$ z całości spadku $^{22}$. Drugim sposobem zakończenia małżeństwa w Turcji jest rozwód. Liczba rozwodów Turcji z roku na rok wzrasta. Najczęstszym impulsem do złożenia przez kobietę pozwu rozwodowego jest osiągnięcie niezależności finansowej. Wcześniej kobiety ze strachu o sytuację bytową rodziny po rozwodzie nie decydowały się na taki krok. Często kobiety pracujące w Turcji zarabiają więcej niż ich mężowie. Oboje małżonkowie mają prawo złożyć pozew o rozwód do sądu rodzinnego. Warunkiem uzyskania rozwodu jest odbycie sześciomiesięcznego okresu separacji. Każdy z małżonków ma prawo ubiegać się o alimenty.

Bardzo niepokojącą kwestią związaną z małżeństwem jest kwestia małżeństw zawieranych przez dzieci (dziewczynki). Zgodnie z raportem Stowarzyszenia Praw Człowieka w Turcji (IHD) o łamaniu praw dziecka w 2002 r. 440 tys. dziewczynek poniżej 18. roku życia urodziło dziecko. Niemniej Zelal Coşkun, członkini Komisji Praw Dziecka przy IHD, powiedziała, że liczba małżeństw dzieci wzrosła w ostatnich latach: „Według danych TÜIKK (Turecki Instytut Statystyczny), w ciągu ostatnich 10 lat 482908 dziewczynek zostało wydanych za mąż z pozwoleniem państwowym. W ciągu ostatnich sześciu lat 142298 z nich zostało matkami. Większość z tych ślubów odbyła się według religijnej (islamskiej]) ceremonii", co w praktyce oznacza, że są nieważne w obliczu obowiązującego prawa ${ }^{23}$. Przyzwolenie władzy co do tego rodzaju praktyk miało miejsce w 2018 r. kiedy to turecki Dyrektoriat ds. Religii wydał wykładnię, zgodnie z którą już 9-letnie dziewczynki mogą legalnie wychodzić za mąż i zachodzić w ciążę. Argumentowano to faktem, że Mohamet zawarł

22 M. Kiebała, Kobieta w prawie tureckim, http://www.politykaglobalna. pl/2009/03/kobieta-w-prawie-tureckim/ [dostęp: 11.05.2019].

23 U. Bulut, Jak islam $w$ Turcji sprzyja małżeństwom dzieci, https:// euroislam.pl/jak-islam-w-turcji-sprzyja-malzenstwom-dzieci/ [dostęp: 9.05.2019]. 
małżeństwo z Aiszą, kiedy miała 9 lat i legalnie z nią współżył. Kolejnym argumentem Diyanet wskazywał, że zgodnie z prawem islamskim początkiem wieku dojrzewania u chłopców jest dwunasty rok życia, a u dziewczynek dziewiąty, a każdy kto osiągnął wiek dojrzewania jest uprawniony do zawarcia związku małżeńskiego. W efekcie publicznych protestów, związanych z powyżej przedstawioną wykładnią, Diyanet wydał jednak oświadczenie, w którym to wskazywał, że jest to jedynie definicja prawa islamskiego. W oświadczeniu turecki Dyrektoriat ds. Religii podkreślił również, że nie będzie zatwierdzał wcześniejszych małżeństw niż te, które mogą być zawarte zgodnie z normami prawa cywilnego. „Turcja jest państwem o najwyższej liczbie małżeństw dzieci w Europie" - napisano w raporcie z 2016 r., autorstwa Organizacji Zapobiegania Przemocy i Rehabilitacji oraz Centrum Badawczego Przestępstw i Przemocy z uniwersytetu Acıbadem w Stambule. Ponieważ jednak małżeństwa religijne (udzielane przez imamów) są tak powszechne, nie było możliwe ustalenie rzeczywistej liczby małżeństw dzieci w Turcji z uwagi na brak dostępu do rejestrów takich małżeństw. W raporcie poruszono również kwestię straszliwych skutków medycznych, psychologicznych oraz społecznych, które będą występowały podczas „dziecięcych ciąż”. Patologia ta dotyczy zarówno nieletnich matek, jak i ich dziecii ${ }^{24}$.

Pomimo że system prawny Turcji w sferze prawa cywilnego opiera się głównie na szwajcarskim kodeksie cywilnym, a nie islamskim prawie szariatu, islamskie nauczanie i tradycje nadal w znacznym stopniu kształtują myślenie i zachowanie wielu ludzi. W szczególności dotyczy to niestety poglądów związanych z małżeństwem, wychowaniem dzieci i ich wykorzystywanie. Największymi ofiarami wpływu islamu na społeczeństwa nadal wydają się być dziewczynki i kobiety.

24 Ibidem. 


\section{Wpływ procesu akcesyjnego Turcji do Unii Europejskiej na prawa kobiet}

Bez wątpienia można stwierdzić, że proces akcesyjny Turcji do UE ma ogromny wpływ na kształtowanie się praw kobiet. Turcja jest państwem granicznym Europy, wynika to z położenia geograficznego oraz tradycji kulturowych. Kultura turecka stała się częścią składową dziedzictwa Europy Południowo-Wschodniej. Z jednej strony nie sposób wyobrazić sobie dzisiejszej Europy bez wpływu kultury osmańskiej na jej rozwój, z drugiej zaś strony nie sposób sobie wyobrazić dzisiejszej Turcji bez wpływu kultury Europy zachodniej. Niemniej jednak odmienność kulturowa Turcji jest wciąż aspektem utrudniającym proces akcesyjny. Turcja złożyła wniosek o pełne członkostwo w we Wspólnocie Europejskiej w 1987 r. Status kandydata Turcja otrzymała dopiero w 1999 r., a negocjacje rozpoczęto dopiero w $2005 \mathrm{r}$. Od początku rozpoczęcia procesu akcesyjnego było wiadomo, że będzie to czasochłonna i skomplikowana procedura. Należy jednak stwierdzić, że od ponad dekady reformy w Turcji coraz bardziej zmierzają do tego, aby sprostać wymaganiom nałożonym przez Unię Europejską.

Ramy prawne dotyczące praw kobiet są „ogólnie zadowalające", ale niedoskonałe jest ich wdrożenie stwierdza - Parlament Europejski w swoim drugim sprawozdaniu poświęconym roli kobiet w życiu społecznym, gospodarczym i politycznym Turcji. Sprawozdanie podkreśla, że poszanowanie praw człowieka, w tym praw kobiet, jest podstawowym warunkiem członkostwa w UE ${ }^{25}$. Rok od przyjęcia rezolucji Parlamentu Europejskiego

25 http://www.europarl.europa.eu/sides/getDoc.do?pubRef=-//EP// NONSGML+IM-PRESS+20070208IPR02887+0+DOC+PDF+V0//PL\&language $=$ PL [dostęp: 10.05.2019] . 
z dnia 6 lipca 2005 r. w sprawie roli kobiet w życiu społecznym, gospodarczym i politycznym Turcji (2004/2215 ( INI) posłowie Parlamentu Europejskiego z zadowoleniem przyjęli rozpoczęcie aktywnej fazy negocjacji akcesyjnych z Turcją. Niepokojący jest jednak fakt, że Turcja spowolniła proces reform. Wciąż jednak aktualny pozostaje temat zbrodni honorowych oraz przemocy wobec kobiet ${ }^{26}$.

Parlament wyraził również zaniepokojenie w kwestii nierejestrowania dziewczynek po urodzeniu. Problem ten występuje głównie w południowo-wschodniej Turcji. Proceder ten utrudnia walkę z łamaniem praw człowieka (kobiet, dziewczynek) $\mathrm{z}$ uwagi na to, że ofiary popełnianych czynów nie posiadają tożsamości oraz dokumentów osobowych. Parlament wytknął również brak danych dotyczących sytuacji kobiet w Turcji, pomimo podjęcia inicjatywy przez turecki Państwowy Instytut Statystyczny, którego celem jest prowadzenie statystyk uwzględniających problematykę płci. Jednak wciąż brak oficjalnych danych w zakresie zbrodni honorowych, przemocy $\mathrm{w}$ rodzinie, poligamii, małżeństw z nieletnimi. Brak danych stanowi poważny problem, przede wszystkim uniemożliwia pomoc ofiarom.

Parlament Europejski bardzo ostro potępia przemoc domową, zbrodnie honorowe, poligamię oraz małżeństwa z nieletnimi. Jasno dano do zrozumienia rządowi tureckiemu, że jest to sfera którą musi zająć priorytetowo. Parlament Europejski wskazuje również, że ważnym elementem jest nie tylko wprowadzenie odpowiednich norm prawnych, ale również wprowadzenie systematycznych szkoleń dla organów policji, sądownictwa w kwestii równouprawnienia i walki z wszelkimi rodzajami przemocy. Niestety problem zbrodni na tle honoru w Turcji nadal nie został wyeliminowany. Parlament

26 Ibidem. 
Europejski po raz kolejny w sprawozdaniu Komisji za $2018 \mathrm{r}$. dotyczącego Turcji (2018/2150(INI)) z zaniepokojeniem odnotowuje wzrost liczby tzw. zabójstw honorowych. Parlament wezwał Turcję do dostosowania krajowych przepisów z Konwencją Rady Europy o zapobieganiu i zwalczaniu przemocy wobec kobiet i przemocy domowej (konwencją stambulską). Ponadto Parlament wzywa Turcję do zapewnienia pełnej równości wszystkim obywatelom oraz do rozwiązania problemów, z jakimi zmagają się członkowie mniejszości, w szczególności w odniesieniu do edukacji i praw własności ${ }^{27}$.

Podsumowując, w listopadzie 2016 r. posłowie Parlamentu Europejskiego przyjęli rezolucję, w której wezwali Komisję Europejską i państwa członkowskie do zawieszenia negocjacji dopóty, dopóki nie ustaną represje i łamanie praw człowieka ze szczególnym uwzględnieniem praw kobiet. Ze względu na wątpliwości co do sytuacji praw człowieka w Turcji Parlament Europejski powtórzył swój apel w rezolucji z lipca $2017 \mathrm{r}$. Chociaż rezolucje nie są wiążące, to stanowią bardzo ważny sygnał dla rządu tureckiego. W związku z powyższym należy stwierdzić, że proces akcesyjny Turcji do Unii Europejskiej ma ogromny wpływ na poprawę ochrony praw kobiet. Jednak należy jasno wskazać, że pomimo wytycznych wskazanych w rezolucjach Parlamentu Europejskiego przed Turcją jeszcze daleka droga, aby osiągnąć satysfakcjonujący dla Unii Europejskiej poziom ochrony praw człowieka, w szczególności praw kobiet. Jak wskazywano powyżej, głównym elementem jaki musi się zmienić w społeczności tureckiej, aby respektować nowo tworzone normy prawne jest odejście od tradycyjnego patriarchalnego modelu rodziny oraz edukacja w zakresie ochrony praw kobiet.

27 Sprawozdanie Komisji za 2018 r. dotyczące Turcji (2018/2150 (INI)), http://www.europarl.europa.eu/doceo/document/A-8-2019-0091_PL.html [dostęp: 10.05.2019]. 


\section{Podsumowanie}

Czy prawa kobiet w Turcji są respektowane? Jaki wpływ na życie kobiety w Turcji ma małżeństwo? Czy zapewnienie ochrony prawnej kobietom ma wpływ na proces akcesyjny Turcji do Unii Europejskiej?

Wstąpienie do Unii Europejskiej pozostaje najważniejszym celem Turcji, ale Ankara coraz częściej patrzy też w innych kierunkach. Na Bliskim Wschodzie (i dalej) dostrzega wielkie możliwości gospodarcze, a Unia Europejska stawia bardzo wysokie wymagania. Kondycja praw człowieka ze szczególnym uwzględnieniem praw kobiet w Turcji ze względu na trwający proces akcesyjny z całą pewnością ulega poprawie. Jednak posiłkując się danymi pochodzącymi z raportów organizacji humanitarnych walczących o prawa kobiet należy stwierdzić, że mimo zmian w prawodawstwie przed Turcją jeszcze daleka droga, jeśli chodzi o stosowanie się do obowiązującego prawa. Turczynki coraz chętniej przyjmują europejskie modele zachowań, walczą o swoje prawa głównie przez to, że dążą do niezależności finansowej, która pozwala podejmować im życiowe decyzje bez obaw o byt. Małżeństwo w Turcji jest jednym z najważniejszych etapów w życiu. Kobiety w Turcji coraz częściej mogą same świadomie podejmować decyzje o zamążpójściu. Niemniej jednak należy pamiętać, że nie wszystkie rejony Turcji rezygnują z typowo patriarchalnego modelu rodziny i patologie w postaci małżeństw dzieci wciąż mają miejsce. Reasumując, przed Turcją jest jeszcze wiele do zrobienia w kwestii ochrony praw kobiet oraz ich swobodnego decydowania o sobie. 


\section{Bibliografia}

Atatürk M.K., Women's Rights, http://ataturk.twoday.net/topics/Women's+Rights/.

Bulut U., Jak islam $w$ Turcji sprzyja matżeństwom dzieci, https://euroislam.pl/jak-islam-w-turcji-sprzyja-malzenstwom-dzieci/.

Büyükbayrar L., Matżeństwo w Turcji - wybrane aspekty, [w:] Bliski Wschód w procesie przemian, red. A. Bryc, M. Dahl, M. Lewicka, Toruń 2015.

„Honor" Crimes Human Rights Watch Oral Intervention at the 57th Session of the UN Commission on Human Rights, https://www.hrw.org/news/2001/04/05/item-12-integration-human-rights-women-and-gender-perspective-violence-against-women.

https://encyklopedia.pwn.pl.

http://www.europarl.europa.eu.

Kiebała M., Kobieta w prawie tureckim, http://www.politykaglobalna.pl/2009/03/kobieta-w-prawie-tureckim/.

Orhan E., Być kobieta w Turcji, https://www.tygodnikprzeglad. pl/byc-kobieta-turcji/.

Rezolucja Parlamentu Europejskiego w sprawie roli kobiet w życiu społecznym, gospodarczym i politycznym Turcji (2004/2215 ( INI)) z dnia 6 lipca 2005 r., oficjalna strona Parlamentu Europejskiego, http://www.europarl.europa.eu/ sides/getDoc.do?pubRef=//EP//TEXT+TA+P6-TA-20050287+0+DOC+XML+V0//PL.

Rezolucja Parlamentu Europejskiego z dnia 27 września 2006 r. $\mathrm{w}$ sprawie roli kobiet $\mathrm{w}$ życiu społecznym, gospodarczym, politycznym Turcji (2006/2214(INI)), http://www.europarl. europa.eu/news/pl/search?planet=_all\&q=Rezolucja+Parlamentu+Europejskiego $+\mathrm{w}+$ sprawie + roli + kobiet $+\mathrm{w}+\% \mathrm{C} 5 \% \mathrm{~B}-$ Cyciu+spo\%C5\%82ecznym\%2C+gospodarczym $+\mathrm{i}+$ politycznym+Turcji+\%282006\%2F2214\%28INI\%29\%29. 
Rezolucja Parlamentu Europejskiego z dnia 22 maja 2012 r. w sprawie przyszłości kobiet w Turcji do 2020 r. (2011/2066 (INI)) (2013/C 264 E/05), https://eur lex.europa.eu/legal content/PL/TXT/PDF/?uri=CELEX:52012IP0212\&from $=\mathrm{RO}$.

Rezolucja Parlamentu Europejskiego z dnia 22 maja 2012 r. w sprawie przyszłości kobiet w Turcji do 2020 r. (2011/2066 (INI)) (2013/C 264 E/05), https://eur lex.europa.eu/legal content/PL/TXT/PDF/?uri=CELEX:52012IP0212\& from $=$ RO.

Sprawozdanie Komisji za 2018 r. dotyczące Turcji (2018/ 2150(INI)), http://www.europarl.europa.eu/doceo/document/A-8=2019=0091_PL.html.

Staśkiewicz W., Gralak K., Konstytucja Republiki Tureckiej, Warszawa 2017.

Szymański A., Między islamem a kemalizmem. Problem demokracji w Turcji, Warszawa 2008.

UNDP, Population Association, UNFPA, The Dynamics of the honour killings in Turkey, https://www.unfpa.org/publications/dynamics-honour-killings-turkey, 2007.

\section{Abstrakt}

W niniejszym artykule poruszono temat praw kobiet w Turcji, a w szczególności ich naruszeń. Ponadto poruszono również kolejny bardzo ważny temat dla kobiet w Turcji, jakim jest małżeństwo. W artykule zostały omówione wybrane aspekty praw kobiet w Turcji, które według autorki mają największe znaczenie podczas procesu akcesyjnego Turcji do UE. Autorka zdecydowała się na omówienie problemu małżeństwa w Turcji z perspektywy kobiety po pierwsze dlatego, że instytucja ta stanowi ważny element tureckiego prawa cywilnego, a po drugie dlatego, że instytucja ta wciąż determinuje życie wielu kobiet w Turcji. Podczas badania wybranych zagadnień dotyczących problematyki praw kobiet poddano analizie wybrane przepisy z obowiązującej w Turcji Konstytucji, a także wybrane 
zagadnienia z tureckiego prawa cywilnego oraz karnego. Podczas rozważań nad powyższymi zagadnieniami autorka doszła do następujących wniosków: proces akcesyjny Turcji do UE ma ogromne znaczenie dla rozwoju praw kobiet w Turcji, a w szczególności wpływa na zapewnienie większej ochrony prawnej kobietom. Jednakże samo tworzenie prawa nie zapewni pełnej ochrony prawnej kobietom, niezbędne jest wprowadzenie działań prowadzących do jego przestrzegania.

Słowa kluczowe: prawa człowieka, prawa kobiet, Turcja, małżeństwo

\begin{abstract}
This article deals with women's rights in Turkey, and in particular their violations. In addition, also they discussed another very important issue for women in Turkey, which is marriage. The article debated selected aspects of women's rights in Turkey, which according to the author are of the greatest importance during Turkey's accession process to the EU. The author decided to discuss the problem of marriage in Turkey from a woman's perspective, firstly because this institution is an important element of Turkish civil law, and secondly, because this institution still determines the lives of many women in Turkey. While the examination of selected issues concerning women's rights, the Constitution in force in Turkey was analyzed, as well as selected issues of Turkish civil and criminal law. During the discussion of these issues the author has come to the following conclusions: the process of Turkey's accession to the $\mathrm{EU}$ is of great importance for the development of women's rights in Turkey, in particular the impact on ensuring greater legal protection to women. However, the very creation of law will not provide full legal protection for women, it is necessary to introduce measures leading to its compliance.
\end{abstract}

Keywords: human rights, women's rights, Turkey, marriage 


\author{
Ksenia Kakareko \\ Uniwersytet Warszawski \\ ORCID ID: https://orcid.org/0000-0003-3707-4479
}

\title{
Państwo i prawa człowieka w nauce społecznej Kościoła prawosławnego
}

Prawa człowieka są koncepcją zrodzoną w kulturze zachodnioeuropejskiej ${ }^{1}$. Trudno zaprzeczyć, że gwałtowny rozwój praw człowieka nastąpił jednak dopiero po II wojnie światowej ${ }^{2}$. Prawa człowieka nie mają jednolitego charakteru, są

1 Źródeł ich upatruje się w Magna Charta Libertatum (Wielkiej Karcie Swobód) z 1215 r., w uchwale konfederacji warszawskiej, podjętej na Sejmie konwokacyjnym 28 stycznia 1573 r. w Warszawie, w Petition of Right (Petycji o prawo), uchwalonej w 1628 r. przez parlament angielski, w Habeas Corpus Act z 13 lutego 1679 r., w Bill of Rights (ustawa o prawach) z 16 grudnia 1689 r., w Karcie Praw Wirginii (Virginia Declaration of Right) z 12 grudnia 1776 r., w Deklaracji Praw Człowieka i Obywatela z 26 sierpnia 1789 r. Godzi się w tym miejscu przypomnieć, że ten ostatni dokument został w $1791 \mathrm{r}$. surowo potępiony w liście pasterskim przez papieża Piusa VI. Podkreślić też należy, że nawet polscy uczeni, zajmujący się problematyką praw człowieka, całkowicie zdają się zapominać o przywileju Neminem captivabimus nisi iure victum, nadanym przez Władysława Jagiełłę w Brześciu Kujawskim 25 kwietnia 1425 r., wprowadzonym w życie przywilejem jedleńskim z 4 marca 1430 r. i przywilejem krakowskim z 9 stycznia 1433 r. oraz rozszerzony na bojarów litewskich w 1447 r. Gwarantował on szlachcie nietykalność osobistą, zapewniając, że nie zostaną przedstawiciele tego stanu uwięzieni bez wyroku sądowego. Nie zauważa się, że ta wolnościowa konstytucja została wydana dwa wieki przed Habeas Corpus Act. Podstaw filozoficznych i doktrynalnych koncepcji praw człowieka dopatruje się zwykle w rozważaniach m.in. J. Locka, J. J. Rousseau, K. Monteskiusza i D. Diderota.

2 Słupami milowymi na tej drodze była Karta Atlantycka z 14 sierpnia 1941 r., Deklaracja Narodów Zjednoczonych, podpisana 1 stycznia 1941 r., deklaracja filadelfijska z 10 maja 1944 r., Karta Narodów Zjednoczonych, podpisana 26 czerwca 1945 r., Powszechna Deklaracja Praw Człowieka z 10 grudnia 1948 r., przyjęta jako rezolucja Zgromadzenia Ogólnego ONZ, Międzynarodowy Pakt Praw Obywatelskich i Politycznych otwarty do pod- 
różnie definiowane $\mathrm{w}$ rozmaitych dokumentach prawa międzynarodowego publicznego, zarówno w wymiarze uniwersalnym (powszechnym), jak i regionalnym. Bywają one także dość odmiennie wykładane przez organy stojące na ich straży. Niepoślednią rolę odgrywa na tym polu Europejski Trybunał Praw Człowieka w Strasburgu w odniesieniu do europejskiej Konwencji praw człowieka i podstawowych wolności oraz Komitet Praw Człowieka w odniesieniu do Międzynarodowego Paktu Praw Obywatelskich i Politycznych. Treść praw człowieka była także wielokrotnie wykładana w doktrynie przez znawców prawa międzynarodowego, konstytucyjnego, a także rozpatrywana z punktu widzenia ich treści filozoficznych, politycznych, a nawet teologicznych. Chrześcijańscy przywódcy religijni, zwłaszcza katoliccy, aż do Soboru Watykańskiego II, Jana XXIII oraz wystąpień Jana Pawła II, odnosili się do praw człowieka z pewną rezerwą, a nawet niechęcią ${ }^{3}$.

pisu 19 grudnia 1966 r., Międzynarodowy Pakt Praw Gospodarczych, Społecznych i Kulturalnych, otwarty do podpisu 19 grudnia 1966 r., Konwencja o prawach dziecka, przyjęta przez ZO ONZ z 20 listopada 1989 r. Niepoślednie znaczenie miały także akty normatywne statuujące prawa człowieka o charakterze regionalnym. W pierwszym rzędzie Europejska konwencja o ochronie praw człowieka i podstawowych wolności z 4 listopada 1950 r., Karta Organizacji Państw Amerykańskich (Karta z Bogoty) uchwalona 30 kwietnia 1948 r., Amerykańska Deklaracja Praw i Obowiązków Człowieka z 2 maja 1948 r., Amerykańska konwencja praw człowieka (określana w literaturze jako pakt z San José) otwarta do podpisu 22 listopada 1969 r., Afrykańska Karta Praw Człowieka i Ludów otwarta do podpisu 27 czerwca 1981 r., Powszechna Islamska Deklaracja Praw Człowieka uchwalona 19 września 1981 r., Kairska Deklaracja Praw Człowieka z 5 sierpnia 1990 r., Arabska Karta Praw Człowieka z 15 września 1994 r. Dla regionu europejskiego, obok Europejskiej konwencji o ochronie praw człowieka i podstawowych wolności, szczególnie ważna jest Karta Praw Podstawowych Unii Europejskiej z 7 grudnia 2000 r., a obok niej Akt Końcowy Konferencji Bezpieczeństwa i Współpracy w Europie z 1 sierpnia 1975 r.

3 Zob. w tym przedmiocie: E. Dudziak, Kościót katolicki wobec praw cztowieka. Ewolucja stanowiska, „Studia z Prawa Wyznaniowego” 2007, t. 10, s. 375-405; F.J. Mazurek, Praw człowieka w nauczaniu społecznym Kościota, Lublin 1991, s. 15; F. Compagnoni, Prawa człowieka. Geneza, historia i zaangażowanie chrześcijańskie, Kraków 2000, s. 119; H. Skorowowski, Pro- 
Dla świata prawosławnego prawa człowieka stanowią kategorią obcą i dlatego przez długi czas były traktowane z dystansem. Niemniej sobór biskupów Rosyjskiej Cerkwi Prawosławnej powierzył synodowi utworzenie grupy roboczej w celu opracowania dokumentu, mającego dotyczyć stosunków Kościoła prawosławnego z państwem świeckim i społeczeństwem na obszarze patriarchatu moskiewskiego ${ }^{4}$. Dokument ten miał określić stanowisko Cerkwi prawosławnej w kwestiach społecznych. Na posiedzeniach na przełomie lat 1996/1997 synod Rosyjskiej Cerkwi Prawosławnej wyłonił grupę 26 osób, wśród których było kilku biskupów, duchownych niższego rzędu, profesorów szkół teologicznych oraz współpracowników departamentów synodalnych. Jednocześnie zaakceptowano metody prac nad dokumentem odnoszącym się do problemów społecznych. Za prace tej grupy roboczej odpowiadał Departament Stosunków Zewnętrznych Patriarchatu Moskiewskiego. Po trzech latach działalności i licznych posiedzeniach przedstawiono wstępne

blematyka praw człowieka, Warszawa 2005, s. 40-50. Por. Kościót i prawa człowieka - dokument Papieskiej Komisji „Iustitia et Pax”, „Więź” 1978, nr 5 (241), s. 39 i n.; Jan Paweł II, Orędzie do Organizacji Narodów Zjednoczonych w Nowym Jorku, 2 października 1979 r., [w:] Jan Pawet II. Nauczanie spoteczne 1978-1979, Warszawa 1982, s. 316; Jan Paweł II, Laborem exercens, [w:] Dokumenty nauki społecznej Kościoła, cz. 2, red. M. Radwan, L. Dyczewski, A. Stanowski, Rzym-Lublin 1987, s. 206.

4 Patriarchat Moskiewski powstał stosunkowo późno. Początkowo istniały patriarchaty w Antiochii, Aleksandrii i Rzymie. Później powstał patriarchat w Konstantynopolu w 380 r., a w 451 r. - w Jerozolimie. Od soboru chalcedońskiego tytuł patriarchy przysługiwał jedynie biskupom posiadającym najszerszą jurysdykcję w Kościele. Patriarchat moskiewski powstał w specyficznej sytuacji politycznej w 1590 r. i został zatwierdzony trzy lata później przez patriarchów Konstantynopola, Antiochii i Jerozolimy. Zob. J. Sobczak, Struktura organizacyjna Cerkwi prawosławnej, „Nowa Polityka Wschodnia” 2018, nr 4 (19), s. 7-38; idem „Teren kanoniczny” Rosyjskiego Kościoła Prawostawnego a prawo do wolności sumienia i wyznania, [w:] Europejski system ochrony praw człowieka. Inspiracja uniwersalna - uwarunkowania kulturowe - bariery realizacyjne, red. J. Jaskiernia, K. Spryszak, Toruń 2016, s. 577-598; M. Banaszak, Historia Kościoła katolickiego, t. 3: Czasy nowożytne 1517-1758, Warszawa 1989, s. 122 
rezultaty prac najpierw na konferencji pt. Teologia prawosławna na progu trzeciego tysiaclecia w lutym $2000 \mathrm{r}$., a następnie na sympozjum pt. Cerkiew i społeczeństwo - 2000. W toku sympozjum podjęto decyzję o opracowaniu dokumentu, w którym chciano zawrzeć oficjalne stanowisko Cerkwi w kwestiach odnoszących się do życia społecznego ${ }^{5}$.

Stosunkowo szybko, bo już 19 lipca 2000 r., na posiedzeniu synodu przedstawiony został dokument Podstawy społecznej koncepcji Rosyjskiej Cerkwi Prawosławnej. Nie da się zaprzeczyć, że zarówno sam dokument, jak i jego założenia zdawały się nawiązywać do rozwiązań nauki społecznej Kościoła rzymskokatolickiego ${ }^{6}$, co nie oznacza jednak, że podzielały stanowiska zawarte $\mathrm{w}$ katolickiej nauce społecznej. Warto w tym miejscu wspomnieć o sporach dotyczących statusu metodologicznego społecznej nauki Kościoła rzymszkokatolickiego ${ }^{7}$.

5 Православное богословие на пороге третьего тысячелетия. Москва, 7-9 февраля 2000 г., Материаль конференции, Москва 2000, http://theolcom.ru/conferences/13-pravoslavnoe-bogoslovie-na-poroge-iiitysyacheletiya [dostęp: 1.02.2020]. Podczas konferencji referat pt. Святоотеческое богословие и секулярный мир (Teologia ojczyzny i świat świecki) wygłosił protojerej Николай ГунАяев, starszy brat późniejszego patriarchy Cyryla.

6 Zob. J. Majka, Katolicka nauka społeczna. Studium historyczno-doktrynalne, Rzym-Lublin 1987; idem, Katolicka nauka społeczna, t. II, Warszawa 1988; T. Głuszak, U początków katolickiej nauki społecznej, „Teologia Praktyczna" 2010, nr 11, s. 189-198; Cz. Strzeżewski, Katolicka nauka spoteczna, Warszawa 1985; T. Ślipko, O wspótczesnej potrzebie katolicyzmu spotecznego, „Annales. Ethics in Economic Life” 2005, nr 1, s. 19-28; idem, Ewolucja katolickiej nauki społecznej, ale jaka?, „Forum Philosophicum” 2004, nr 9, s. 233-240; S. Pyszka, Ewolucja katolickiej nauki spolecznej w latach 1891-2003, „Forum Philosophicum” 2003, nr 8, s. 121-146; R. Czekalski, Rozwój katolickiej nauki społecznej po Soborze Watykańskim II ze szczególnym uwzględnieniem pontyfikatu Jana Pawta II, „Warszawskie Studia Teologiczna" 2011, vol. XXIV, nr 1, s. 45-62. Por. także: V. Possenti, Katolicka nauka społeczna wobec dziedzictwa Oświecenia, Kraków 2000, s. 201.

T. Borutka, Propedeutyka katolickiej nauki spotecznej, [w:] T. Borutka, J. Mazur, A. Zwoliński, Katolicka nauka spoteczna, Częstochowa 1999, s. 23; H. Juros, Katolicka nauka społeczna contra teologia (moralna) spoteczna. Uwagi metodologiczne do Orędzia Jana Pawła II na Międzynarodowy Dzień 
Kilka tygodni później wspomniany dokument został przyjęty na Jubileuszowym Soborze Biskupów w sierpniu 2000 r. ${ }^{8}$

Podstawy społecznej koncepcji rosyjskiego Kościoła prawosławnego to dokument podzielony na szesnaście rozdziałów, w których zwrócono uwagę m.in. na stosunek Kościoła prawosławnego do narodu (rozdział II), odniesienia między Kościołem a państwem (rozdział III), stosunek Kościoła do polityki (rozdział V). Omówiono kwestie pracy (rozdział VI), własności (rozdział VII), wojny i pokoju (rozdział VIII), przestępczości, wymiaru sprawiedliwości i kwestie penitencjarne (rozdział IX). Zajęto się także w tym dokumencie prywatnością, rodziną, moralnością (rozdział X), ochroną zdrowia, także w aspekcie narodowym (rozdział XI), bioetyką (rozdział XII), ekologią (rozdział XIII), nauką, kulturą i edukacją (rozdział XIV), środkami masowej informacji (rozdział XV), wreszcie stosunkami międzynarodowymi (rozdział XVI). Tekst poszczególnych rozdziałów został podzielony na paragrafy, przy czym szczególnie ważne kwestie wyboldowano. Wątpliwości może budzić status prawny „podstaw społecznej koncepcji...” Niewątpliwie jest to dokument wewnętrzny Rosyjskiej Cerkwi Prawosławnej, jednak ma on ambicje wywarcia wpływu na inne autokefaliczne i autonomiczne Kościoły prawosławne9.

Pokoju 1998, [w:] idem, Europejskie dylematy i paradygmaty, Warszaw 2003, s. 23-38; idem, Wokót tożsamości katolickiej nauki spotecznej, [w:] idem, Europejskie dylematy i paradygmaty, Warszaw 2003, s. 18-22.

8 Определение Юбилейного Архиерейского Собора «Об основах социальной концепиии Русской Православной Церкви», https:/mospat.ru/ archve/page/sobors/2000-2/384.html [dostęp: 19.02.2018]; Основы социальной концепции Русской Православной Церкви, Юбилейный Архиерейский Собор Русской Православной Церкви, Москва 2000.

9 Autokefalii nie można mylić z autonomią. Koniecznym warunkiem otrzymania autokefalii jest wyodrębnienie się z dotychczasowej struktury odrębnego Kościoła lokalnego i funkcjonowanie w takim Kościele minimum czterech biskupów. Ponadto Kościół ubiegający się o autokefalię powinien legitymować się istnieniem na swoim obszarze ośrodków życia monastycznego (klasztorów męskich i żeńskich), funkcjonowaniem seminarium lub 
O tych ambicjach świadczy z jednej strony zakończenie dokumentu, w którym wskazuje się, że jego treść przedstawia się „braterskiej uwadze Lokalnych Kościołów Prawosławnych w nadziei na to, że będzie on służyć wzrastaniu jednomyślności i pomoże w koordynacji działań praktycznych". Przy czym dodano, że do studiów nad dokumentów zaprasza się też inne Kościoły i zjednoczenia chrześcijańskie, inne wspólnoty religijne. $Z$ drugiej strony na zamiary takie wskazywać może także fakt, że został on przetłumaczony na wiele języków, m.in. angielski, bułgarski, czeski, francuski, niemiecki, polski, a nawet farsi. Dokument uwzględnia decyzje podjęte na wcześniejszych soborach Rosyjskiej Cerkwi Prawosławnej, ale z natury rzeczy nie dotyczy sytuacji w innych Kościołach lokalnych. Tymczasem kwestie te mogą być dość ważne, chociażby w odniesieniu do okoliczności, będących podstawami do rozwiązywania związków małżeńskich. Zgodzić się przy tym należy z opinią, że jest to niewątpliwie najbardziej kom-

akademii kształcącej przyszłych duchownych. Nowo powstały Kościół autokefaliczny winien przy tym pozostawać w łączności i wspólnocie kanonicznej ze wszystkimi Kościołami autokefalicznymi. Nie może wprowadzać nowych dogmatów, naruszać tradycji i zwyczajów kościelnych oraz zasad prawnych Kościoła powszechnego. Nie istnieją kanony dotyczące ustanawiania autokofelii. Procedury jej utworzenia opierają się na normach prawa kanonicznego i świadomości prawnej poszczególnych Kościołów. Wprawdzie autokefalia nie może być ustanawiana w celu zaspokojenia dążeń narodowościowych, ale w praktyce przyczyną dążenia do autokefalii bywa uzyskanie niepodległości przez jakieś państwo. Autonomiczne kościoły prawosławne mają zblizzoną do autokefalii, ale jednak ograniczoną niezależność organizacyjną i administracyjną, pozostając pod jurysdykcją innego Kościoła prawosławnego, będącego Kościołem macierzystym. Ustrój wewnętrzny kościoła autonomicznego, związany jest z ustrojem Kościoła macierzystego, od którego Kościół autonomiczny ma obowiązek uzyskania pełnomocnictw dla swojej działalności, przy czym nie może wykraczać w swoich aktach prawodawczych w administracji i sądownictwie poza granice praw wytyczone przez Kościół macierzysty. Por. J. Tofiluk, Autokefalia w rozumieniu Kościoła prawosławnego, [w:] Autokefalie Kościoła prawosławnego w Polsce, red. A. Mironowicz, U. Pawluczuk, P. Chomik, Białystok 2006, s. 18 i n.; Autonomia i sposób jej ogtaszania. Dokumenty przyjęte przez Święty i Wielki Sobór Cerkwi Prawostawnej Kreta, 18-26.06.2016 r., „Cerkiewny Wiestnik” 2016, nr 4, s. 41. 
pleksowy dokument dotyczący nauki społecznej, jaki powstał w Kościołach prawosławnych ${ }^{10}$.

Podstawy społecznej koncepcji Rosyjskiej Cerkwi Prawostawnej bywają mylone z późniejszym dokumentem Podstawy nauki Rosyjskiej Cerkwi Prawosławnej o godności, wolności i prawach człowieka, który został zatwierdzony 26 czerwca 2008 r. przez sobór biskupów Rosyjskiej Cerkwi Prawosławnej. Pomyłki te są całkowicie niezrozumiałe i nieusprawiedliwione, gdyż w tym ostatnim dokumencie stwierdza się, że jest on rozwinięciem podstaw społecznej koncepcji Rosyjskiej Cerkwi Prawosławnej. Warto zauważyć, że wcześniej została sformułowana Deklaracja o Prawach i Godności Człowieka, zatwierdzona przez X Światowy Sobór Narodu Rosyjskiego (Всемирный русский народныци coбop), który odbywał 4-6 kwietnia 2006 r. ${ }^{11}$

Treść Podstawy nauki Rosyjskiej j Cerkwi Prawostawnej o godności, wolności i prawach człowieka została zawarta w pięciu rozdziałach rozbitych na mniejsze części, poprzedzonych preambułą, w której podkreślono, że mimo głębokich różnic między poszczególnymi cywilizacjami i kulturami, każda z nich ma własny sposób podejścia do praw i obowiązków człowieka. Kolejne rozdziały poświęcono: godności człowieka jako kategorii religijno-moralnej (rozdz. I), wolności wyboru i wolności od zła (rozdz. II), prawom człowieka w rozumieniu chrześcijańskim i w życiu człowieka (rozdz. III). W ramach trzeciego rozdziału poświęcono uwagę rozważaniom dotyczącym tego, że prawa

10 J. Kostiuczuk, Społeczne nauczanie Kościoła prawosławnego, Warszawa 2018, s. 36.

11 Światowy Sobór Narodu Rosyjskiego, który odbył się w 1993 r. z inicjatywy Aleksego II stanowić miał w założeniu platformę spotkań przedstawicieli różnych nurtów życia rosyjskiego w kraju i na emigracji. Jest on pomyślany jako miejsce spotkań duchowieństwa, władz świeckich, uczonych z uniwersytetów i akademii nauk, przedstawicieli związków twórczych, organizacji pozarządowych i młodzieży z rosyjskich wspólnot zagranicą. Zob. H.A. Баранов, Взаимодействие Церкви и государства в современной России, „Южно-российский журнал социальных наук” 2009, nr 4, s. 97-108. 
człowieka nie mogą być stawiane ponad wartościami duchowymi i winny one być uzgadniane $\mathrm{z}$ normami moralnymi, wreszcie, że nie mogą być sprzeczne z miłością do Ojczyzny i bliźnich, a ich realizacja nie może prowadzić do degradacji środowiska i wyniszczenia zasobów przyrodniczych. W przedostatnim obszernym rozdziale poruszono kwestie godności i wolności w systemie praw człowiek, omawiając prawo do życia, kwestie wolności sumienia, wolności słowa, wolności twórczości, wreszcie prawa do wykształcenia, praw obywatelskich i politycznych, społeczno-ekonomicznych oraz praw grupowych. Ostatni rozdział poświęcono przedstawieniu zasad i kierunków działalności w dziedzinie ochrony praw Rosyjskiej Cerkwi Prawosławnej.

Znamiennym jest fakt, że zasadnicza treść Podstaw nauki... rozpoczyna się od rozważań dotyczących godności człowieka. Podobnie, jak to ma miejsce w treści Karty Praw Podstawowych Unii Europejskiej, zwraca się uwagę, że pojęcie „godności” w tradycji wschodniej ma w pierwszej kolejności sens moralny, w wszystko, co rozumie się jako godne albo niegodne jest nierozerwalnie związane z postępowanie moralnym lub niemoralnym. Życie godne to według Podstaw nauki... życie zgodne z pierwotnym powołaniem wpisanym w naturę człowieka. Autorzy dokumentu wywodzą przy tym, że godność człowieka dana została przez Boga i potwierdza ją obecność w każdym człowieku pierwiastka moralnego. Przywołując tradycję prawosławną zauważa się, że zachowanie przez człowieka godności danej mu przez Boga i wzrastanie w niej jest uwarunkowane przez życie zgodne z normami moralnymi, które wyrażają pierwotną, a więc autentyczną naturę ludzką, nieotumanioną grzechem. Dlatego też między godnością ludzką i moralnością istnieje bezpośredni związek, którego skutkiem jest odpowiedzialność moralna człowieka.

Człowiek wg twórców Podstaw nauki... ma wolność wyboru i wolną wolę, aczkolwiek nie jest to wolność absolutna i osta- 
teczna. Winna ona służyć dobru człowieka, który nie powinien przysparzać zła ani sobie samemu, ani swojemu otoczeniu. Uznając wolność wyboru twórcy Podstaw nauki... podkreślają, że zanika ona nieuchronnie, gdy wybór dokonywany jest w stronę zła. Zło i wolność są bowiem nie do pogodzenia. Stwierdzając to podkreślono w dokumencie, że nie do przyjęcia są takie zjawiska, jak: aborcja, samobójstwo, rozpusta, rozbicie rodziny, kult chamstwa i przemocy. Zauważono przy tym, że słabość świeckich instytucji praw człowieka polega na tym, że bronią one wolności wyboru, nie licząc się z moralnym wymiarem życia i wolnością od grzechu. Podniesiono, że nie wolno bronić jednej wolności, zapominając o pozostałych.

W dokumencie zauważono, że wyobrażenie o prawach człowieka przeszły długą ewolucję historyczną i chociażby tylko $\mathrm{z}$ tego powodu nie mogą być absolutyzowane w ich obecnym rozumieniu. Wartości chrześcijańskie powinny harmonizować prawa człowieka, a społeczeństwo musi tworzyć mechanizmy przywracające harmonię ludzkiej godności i wolności. Temu właśnie mogą i powinny służyć koncepcje praw człowieka. Zauważono przy tym, że erozja moralności zawsze prowadzi do unicestwienia praworządności. W dalszej części zauważono, że prawa człowieka nie są ustanowione przez Boga, co zdaje się nieco kłócić ze wcześniejszymi stwierdzeniami, że godność człowieka dana jest przez Boga. Nie powinny one wchodzić w konflikt z objawieniem Bożym. Zauważa się przy tym, że obok idei osobistej wolności ważna jest także kategoria tradycji, przekazu i moralności, z którymi wolność powinna być uzgodniona. Stworzone przez człowieka formy i mechanizmy ustroju społeczno-politycznego nie mogą, zdaniem twórców Podstaw nauki..., uczynić życia bardziej moralnym i doskonałym ani wykorzenić zła i cierpień. Natomiast państwa i społeczeństwa winny starać się zapobiegać złu w jego przejawach społecznych. Wskazano przy tym, że społeczeństwo organizując życie ziem- 
skie powinno brać pod uwagę nie tylko ludzkie sprawy i pragnienia, ale także dane przez Stwórcę wieczne prawo moralne.

Podkreślono, że opracowanie i przyjęcie koncepcji praw człowieka powinno być uzgodnione z normami moralnymi. Prawa te nie mogą stanowić podstawy dla zmuszania chrześcijan do naruszania przykazań boskich. Podniesiono, że niedopuszczalne są próby podporządkowania poglądów wierzących na człowieka, rodzinę i życie społeczne. Za niedopuszczalne uznano także wprowadzanie $\mathrm{w}$ dziedzinę praw człowieka norm „rozmywających" moralność ewangeliczną i naturalną. Za ogromne niebezpieczeństwo uznano udzielanie prawnego i państwowego poparcia różnego rodzaju występkom, w tym seksualnemu rozprężeniu i zboczeniom, kultowi zysku i przemocy. W tej samej mierze za niedopuszczalne uznano działania niemoralne i antyhumanitarne w stosunku do człowieka, takie jak: aborcja, eutanazja, wykorzystywanie embrionów ludzkich w medycynie bądź eksperymenty zmieniające naturę człowieka.

Prawa człowieka powinny być zrównoważone przez sankcjonowanie wzajemnej odpowiedzialności ludzi względem siebie. Zarówno indywidualizm, jak i kolektywizm mogą służyć harmonijnej organizacji życia społecznego, ale mogą także prowadzić do degradacji osoby ludzkiej, moralnego i prawnego nihilizmu, wzrostu przestępczości, utraty aktywności obywatelskiej i alienacji ludzi. Nieuchronne napięcia między interesami indywidualnymi i społecznymi mogą być przezwyciężone wtedy, gdy prawa i wolności człowieka będą zgodnie z wartościami moralnymi, a życia ludzi i społeczeństwa będzie ożywiane przez miłość. Jednocześnie wskazano w Podstawach nauki..., że działania nakierowane na przestrzeganie praw człowieka oraz doskonalenie społecznych stosunków i instytucji nie mogą być zwieńczone pełnym sukcesem, jeżeli będą ignorować duchowe i kulturalne tradycje krajów i narodów. Mocno zaakcentowano, że pod pozorem obrony praw człowieka jedne 
cywilizacje nie mają prawa narzucania swojej koncepcji życia innym. Obrona praw nie może służyć interesom politycznym poszczególnych państw. Podniesiono, że walka o prawa człowieka będzie owocną wtedy, gdy będzie służyć duchowemu i materialnemu dobru osoby ludzkiej i społeczeństwa.

Kościół prawosławny postrzega państwo jako ważny element w budowaniu prawidłowych relacji społecznych, zabezpieczaniu porządku i sprawiedliwości. Państwo i sprawujący w nim władzę są nieodzownym elementem „w skażonym przez grzech świecie”, aczkolwiek państwo i jego struktury nie wynikają z woli Bożej, jednak są światu potrzebne. Anarchia i przemoc, które pojawiają się po rozpadzie struktur państwowości są przeciwne porządkowi ustanowionemu przez Boga ${ }^{12}$. W stosunkach Kościoła prawosławnego z państwem najważniejszy jest wzajemny szacunek i unikanie kolizji kompetencji ${ }^{13}$. Kościół prawosławny obecny jest w państwach o różnych ustrojach politycznych. Musi jednak budować relacje tak, aby sprawować posługę z najlepszym skutkiem. Unikając konfliktu z władzami nie może jednak zapominać o ewangelicznych prawdach, co nie zawsze będzie mile widziane przez władze określonych religii ${ }^{14}$.

Rosyjska Cerkiew Prawosławna wskazuje na konieczność utrzymywania bezstronności wobec działań politycznych. Powinna jednak bronić swojej pozycji w społeczeństwie, dbać o prawidłowe wychowanie w wierze i postawę moralną swoich wiernych. Musi się sprzeciwiać, gdyby organy państwowe zmuszały wiernych do apostaci lub grzechu. Winien też protestować przeciwko niesprawiedliwości, starać się uczestniczyć

12 Основы сочиальной кониепции Русской Православной Церкви, Юбимейный Архиерейский Собор Русской Правоскавной Церкви, Москва 2000, s. 10.

13 J. Kostiuczuk, Społeczne nauczanie..., op.cit., s. 125.

14 J. Matwiejuk, Konstytucyjno-ustawowa pozycja związków wyznaniowych w Federacji Rosyjskiej, Białystok 2016, s. 20. 
w procesie legislacyjnym, eksponując kwestie polityczne, które mają implikacje moralne ${ }^{15}$. Podkreśla się jednak, że duchowni nie mogą sprawować władzy świeckiej, należeć do organizacji politycznych, prowadzić działalności politycznej, brać udział w kampaniach wyborczych. Nie może jednak zabraniać swoim wiernym wyrażania poglądów politycznych. Nie powinni oni jednak należeć do partii i organizacji politycznych, które występują przeciwko wartościom chrześcijańskim i nauce Kościoła prawosławnego. Nawet wówczas, gdy oficjalna polityka państwowa byłaby sprzeczna z nauczaniem Kościoła prawosławnego, Kościół nie powinien wzywać do buntu i podejmowania zbrojnej walki przeciwko panującemu ustrojowi.

Człowiek dla zaspokojenia swoich egoistycznych interesów nie może marnować zasobów przyrodniczych. Nieograniczone dążenie do zaspokojenia potrzeb materialnych, szczególnie potrzeb zbytkownych i sztucznych jest grzeszne, gdyż prowadzi do wyczerpania duszy człowieka i otaczającej go przyrody. Naturalne bogactwa ziemi to istota nie tylko majątku człowieczego, ale przede wszystkim wynik działania Stwórcy. Godność człowieka jest więc nierozdzielna od jego troski o świat. Chcąc zachować tę godność, należy zachować umiar w zaspokajaniu swoich potrzeb i troskliwie chronić bogactwo, różnorodność i piękno przyrody. Kwestie te powinny być z całą powagą brane pod uwagę przez społeczeństwo i państwo w określaniu głównych celów rozwoju społeczno-ekonomicznego i materialno-technicznego. Członkowie społeczeństwa powinni pamiętać, że nie tylko obecne, ale także przyszłe pokolenia mają prawo posługiwania się bogactwami przyrody. Wywiedziono, że z punktu widzenia Kościoła prawosławnego instytucja praw człowieka może służyć dobrym celom obrony godności ludzkiej oraz wspierać duchowy

15 S. Harakas, Kościót prawosławny wobec kwestii moralnych, [w:] Światto wiary i zdrój doświadczenia, red. K. Leśniewski, J. Leśniewska, Lublin 1999, s. 270. 


\section{i moralny rozwój człowieka ${ }^{16}$. Indywidualne prawa człowieka nie}

16 Pojęcie „godności człowieka” w ostatnim czasie stało się niezmiernie popularne w rozważaniach prawników, szczególnie tych, którzy poświęcają uwagę prawu europejskiemu, głównie wspólnotowemu (unijnemu), oprócz tego zaś w środowisku teologów i filozofów. Przyczyny tego stanu rzeczy są dwojakie. Z jednej strony wydaje się to być skutkiem zwrócenia uwagi na "godność człowieka” w Karcie Praw Podstawowych Unii Europejskiej z komentarzem, która widzi w niej nie tylko podstawowe prawo, ale i źródło wszystkich praw człowieka. Zob. S. Hambura, M. Muszyński, Karta praw podstawowych, Bielsko-Biała 2001, s. 38-39. Po drugie do pojęcia tego zaczęła odwoływać się w swoich dokumentach społeczna nauka kościoła katolickiego, zob. J.W. Gałkowski, Jan Paweł II o godności człowieka, [w:] J. Czerkawski, Zagadnienie godności człowieka, Lublin 1994, s. 108 i n.; F.J. Mazurek, Godność osoby ludzkiej podstawą praw człowieka, Lublin 2001, passim, tamże obszerne omówienie literatury. Wbrew jednak pozorom pojęcie godności, jako kategoria prawna, w obszarze prawa międzynarodowego i praw człowieka nie jest nowością. Mówi o niej wyraźnie w preambule Powszechna Deklaracja Praw Człowieka z 10 grudnia 1948 r. stwierdzając: „Zważywszy, że uznanie przyrodzonej godności oraz równych i niezbywalnych praw wszystkich członków rodziny ludzkiej stanowi podstawę wolności, sprawiedliwości i pokoju na świecie..., zob. Powszechna Deklaracja Praw Człowieka [w:] K. Motyka, Prawa człowieka: wprowadzenie, wybór źródet, Lublin 2004, s. 125 oraz w treści art. 1, w którym zauważono: „Wszystkie istoty ludzkie rodzą się wolne i równe w swej godności i swych prawach (...)”. Odwołuje się do niej także Międzynarodowy Pakt Praw Obywatelskich i Politycznych z 16 grudnia 1966 r., stwierdzając w preambule: „Zważywszy, że zgodnie z zasadami ogłoszonymi w Karcie Narodów Zjednoczonych uznanie przyrodzonej godności oraz równych i niezbywalnych praw wszystkich członków wspólnoty ludzkiej stanowi podstawę wolności, sprawiedliwości i pokoju na świecie, uznając, że prawa te wynikają z przyrodzonej godności człowieka (...)”. Do sformułowań odnoszących się do godności istoty ludzkiej, a przy okazji do Karty Narodów Zjednoczonych, akcentując, że oparta jest ona na zasadzie godności i równości wszystkich istot oraz do Powszechnej Deklaracji Praw Człowieka odwołuje się w preambule Międzynarodowa konwencja w sprawie likwidacji wszelkich form dyskryminacji rasowej z 7 marca 1966 r. (Dz.U. 1969, nr 25, poz. 187 - załącznik). Do tych samych aktów prawnych i do pojęcia „godności” odwołują się także w preambułach konwencje: w sprawie likwidacji wszelkich form dyskryminacji kobiet z 18 grudnia 1979 r. (Dz.U. 1982, nr 10, poz. 71 - załącznik), w sprawie zakazu stosowania tortur oraz innego okrutnego, nieludzkiego lub poniżającego traktowania albo karania z 10 grudnia 1984 r. (Dz.U. 1989, nr 63, poz. 378 - załącznik), o prawach dziecka z 20 listopada 1989 r. (Dz.U. 1991, nr 120, poz. 526), przy czym dwie ostatnie z nich akcentują "przyrodzony” charakter tejże „godności”. Warto jednak zauważyć, że zarówno wspomniane konwencje, jak i przywoływane przez nie inne akty prawa międzynarodowego, nie definiują żaden sposób pojęcia: 
mogą być przeciwstawiane wartościom i interesom Ojczyzny, wspólnoty i rodziny. Realizacja ich nie usprawiedliwia targnięcia się na świętości religijne, wartości kulturalne oraz samoistność narodu.

W dalszej części Podstaw nauki... wskazano, że istnieją różne tradycje i narodowe specyfiki realizacji kompleksu praw i swobód człowieka. Zauważono, że współczesny system praw człowieka jest rozgałęziony i wykazuje tendencje do dalszego rozwarstwienia. Podkreślono, że prawo do życia jest jednym z najważniejszych praw, a prawosławie odrzuca terroryzm, zbrojną agresję i wszelkie formy przestępczego odbierania życia ludzkiego, w tym oczywiście eutanazję, zabójstwo i samobójstwo. Podkreślono, że międzynarodowe i narodowe akty prawne chronią życie dziecka, człowieka dorosłego i starego. Winny więc chronić także życie człowieka od momentu jego poczęcia. Niezbyt jasno wypowiada się w dalszej części dokument w kwestii stosunku do kary śmierci, stwierdzając, że brak w przeka-

„godność”. Wypada w tym miejscu, z pewnym zdziwieniem, skonstatować, że do pojęcia "godność" nie odwołuje się Europejska Konwencja o ochronie praw człowieka i podstawowych wolności (Dz.U. 1993, nr 61, poz. 284) ani Amerykańska konwencja praw człowieka z 22 listopada 1969 r. Zob. T. Jasudowicz (red.), Wspólny standard do osiagnięcia. Stan urzeczywistnienia. W pięćdziesięciolecie Powszechnej Deklaracji Praw Człowieka z 10 grudnia 1948 r., Toruń 1998, s. 28, ani Afrykańska Karta Praw Człowieka i Ludów z 26 czerwca 1981 r., natomiast posiłkuje się nim Powszechna Islamska Deklaracja Praw Człowieka. Zob. W. Sobczak, Powszechna Islamska Deklaracja Praw Człowieka, w druku, tamże tłum. tekstu z j. arabskiego, stwierdzając: „tak jak za życia, tak po śmierci godność ludzkiego ciała winna zostać nieskalana”. Autorzy Powszechnej Islamskiej Deklaracji zdają się w tej sytuacji zwracać uwagę nie tyle na poczucie godności i część zewnętrzną oraz wewnętrzną, dobre imię i godność osobistą, co na szacunek dla ciała ludzkiego. Do określenia "godność” odwołuje się także Proklamacja teherańska z 13 maja 1968 r. wzywając „wszystkie ludy i rządy do wierności zasadom wpisanym w Powszechną Deklarację Praw Człowieka oraz do podwojenia ich wysiłków na rzecz zapewnienia wszystkim istotom ludzkim życia zgodnego z ich wolnością i godnością, prowadzącego do ich dobrobytu fizycznego, umysłowego, społecznego i duchowego" oraz Akt końcowy Konferencji Bezpieczeństwa i Współpracy w Europie z 1 sierpnia 1975 r. 
zach starego i nowego testamentu podstaw przemawiających za likwidacją takiej kary. Zauważono jedynie, że Rosyjska Cerkiew Prawosławna, broniąc życia ludzkiego, powinien być orędownikiem osób skazanych na śmieć.

Rozważając kwestie wolności sumienia w Podstawach nauki... stwierdzono, że zasada wolności sumienia tworzy harmonię z wolą bożą, zapewniając człowiekowi ochronę przed narzucaniem mu siłą różnych przekonań. W warunkach państwa świeckiego głoszona i chroniona przez prawo wolność sumienia umożliwia Kościołowi zachowanie własnej integralności, niezależności od ludzi posiadających inne przekonania, stwarzając podstawy prawne dla nietykalności w życiu wewnętrznym, jak i publicznym. Zauważono jednak w treści dokumentu, że umocnienie prawnej zasady wolności sumienia świadczy o zatraceniu przez społeczeństwo celów religijnych i wartości. Wywiedziono, że wolność sumienia nie może być traktowana jako żądanie religijnej neutralności lub indyferentności państwa i społeczeństwa. Podkreślono, że nie do przyjęcia dla Rosyjskiej Cerkwi Prawosławnej jest ideologiczna interpretacja wolności religijnej w ten sposób, że uznaje się, że wszystkie wierzenia są jednakowo w prawdzie. W dalszej części zauważono mimo to, że społeczeństwo ma prawo do swobodnego określenia treści i zakresu współdziałania państwa z różnymi wspólnotami religijnymi w zależności od ich liczebności, wkładu do dziejów państwa lub regionu poprzez historię i kulturę. Społeczeństwo - jak zauważono - musi przy tym zachowywać zasady równości obywateli wobec prawa, bez względu na ich stosunek do religii. Podkreślono, że zasada wolności sumienia nie stanowi przeszkody dla partnerskich stosunków Kościoła i państwa w działalności społecznej, dobroczynnej, oświatowej oraz na innych znaczących społecznie polach. Stanowczo stwierdzono, że nie wolno powołując się na wolność sumienia, wypaczać istotę tej zasady, ustanawiając wszechogarniającą kontrolę nad życiem i poglądami 
człowieka, burząc w ten sposób moralność osobistą, rodzinną i społeczną. Niedopuszczalne jest obrażanie uczuć religijnych, szydzenie ze świętości, szkodzenie duchowo-kulturalnej samodzielności narodu.

W kolejnej części Podstaw nauki... wywiedziono, że wolność wyrażania myśli i uczuć, stwarzająca możliwość rozpowszechniania informacji, stanowi naturalną kontynuację wolności wyboru światopoglądowego. Jednak wystąpienia publiczne nie powinny sprzyjać szerzeniu grzechu, rodzić kłótnie i nieporządki w społeczeństwie. Za szczególnie niebezpieczne uznano obrażanie uczuć religijnych i narodowych, wypaczanie informacji o życiu wspólnoty religijnych, narodów, grup społecznych i poszczególnych osób. Mocno podkreślono, że słowo powinno tworzyć i podtrzymywać dobro.

W tekście Podstaw nauki... zauważono, że wolność twórczości nie powinna być realizowana $w$ formach obraźliwych dla poglądów i sposobu życia innych członków społeczeństwa. Wyszydzanie świętości nie może być usprawiedliwione odwoływaniem się do praw malarza, pisarza i dziennikarza. Wywiedziono, że współczesne prawodawstwo zwykle chroni nie tylko życie i majątek ludzi, ale także pewne wartości symboliczne, takie jak pamięć o zmarłych, miejsca pochówków, pomniki historii i kultury, symbole państwowe. Taką ochroną powinny być objęte także przedmioty kultu.

Wykształcenie uznano w dokumencie nie tylko za środek dla zdobycia wiedzy lub socjalizacji, lecz także za działanie odpowiadające zamysłom Stwórcy. Prawo do wykształcenia powinno brać pod uwagę tradycje kulturalne społeczeństwa oraz światopogląd rodziny. Zważywszy, że u podstaw większości kultur istnieje religia, dlatego też wszechstronne wykształcenie i wychowanie musi zawierać przekaz wiadomości o religii, która stworzyła kulturę, w której określony człowiek żyje. 
Rozważając prawa obywatelskie i polityczne wywiedziono, że stwarzają one człowiekowi szerokie możliwości dla służby bliźnim i wpływania na życie społeczeństwa, a także kierowania sprawami państwa. Posiłkowanie się tymi prawami nie powinno prowadzić do podziałów i wrogości. Zgodnie z tradycją prawosławną, konieczne jest zachowanie jedności społeczeństwa w oparciu o nieprzemijające wartości - o dobro wspólne ${ }^{17}$.

17 Dyskusyjne w literaturze wydaje się to czy dobro wspólne czy też może przyrodzona godność człowieka - jest wartością fundamentalną oraz jaki jest charakter wspomnianego dobra wspólnego. Podnosi się zwykle, że pojęcie „dobra wspólnego” różni się dość istotnie od „wspólnego dobra”. Dobro wspólne, jako podstawową wartość konstytucyjną, mocno lansuje M. Piechowiak w kilku wartościowych publikacjach: idem, W sprawie aksjologicznej spójności Konstytucji RP. Dobro wspólne czy godność człowieka?, [w:] Jedność aksjologiczna systemu prawa w rozwijających się państwach demokratycznych Europy, red. S.L. Stadniczeńko, Opole 2010, s. 28 i n.; idem, Stużebność państwa wobec człowieka i jego praw jako naczelna idea Konstytucji RP z 2 kwietnia 1997 r. osiagnięcie czy zadanie, „Przegląd Sejmowy” 2007, nr 4 (81), s. 65-89; idem, Konstytucyjna zasada dobra wspólnego - w poszukiwaniu kontekstu interpretacji, [w:] Dobro wspólne. Problemy konstytucyjnoprawne i aksjologiczne, red. W. Wołpiuk, Warszawa 2008, s. 1, 23-158; idem, Prawnonaturalny charakter klauzuli dobra wspólnego (w druku); Równi w prawach i powinnościach wobec dobra wspólnego - Polski, [w:] Preambuła Konstytucji Rzeczypospolitej Polskiej, red. Zespół Prezydialny Biura TK, Warszawa 2009, s. 111-124; idem, Filozoficzne podstawy rozumienia dobra wspólnego, „Kwartalnik Filozoficzny” 2003, nr 31, nr 2, s. 5-35. „Dobro wspólne” jako wyrażenie idiomatyczne jest dobrze ugruntowane w nauce społecznej Kościoła rzymskokatolickiego. Zgodnie z nią dobro wspólne to suma warunków życia społecznego jakie bądź zrzeszeniom, bądź poszczególnym członkom społeczeństwa pozwalają osiągać w pełni i łatwiej własną doskonałość. Zob. Sobór Watykański II, Konstytucja duszpasterska o Kościele w świecie wspótczesnym, Gaudium et spes, s. 26; Acta Apostolicae Sedis (dalej: AAS) 58, 1996, 1046; por. Katechizm Kościota Katolickiego, 1905-1912; Jan XXIII, Encyklika Mater et magistra: AAS 53 (1961), s. 417-421; idem, Encyklika Pecem in terris: AAs 55 (1963), s. 272-273; Paweł VI, List apostolski Octogesima adveniens, 46: AAS 63 (1971), s. 433-435. Zob. także: Kompendium nauki społecznej Kościoła, Kielce 2005, s. 97. W doktrynie polskiej „dobro wspólne wszystkich obywateli” obejmuje, jak wskazuje się w doktrynie, sumę warunków życia społecznego, a polegać ma na poszanowaniu praw i obowiązków osoby ludzkiej. Por. M. Piechowiak, Filozoficzne podstawy rozumienia dobra wspólnego, „Kwartalnik Filozoficzny” 2003, t. 31, z. 2, s. 6; M. Zdyb, dobro wspólne w perspektywie art. 1 Konstytucji Rzeczypospolitej Polskiej, [w:] Trybunat Konstytucyjny księga XV-lecia, red. F. Rymasz, A. JankiewiczWarszawa 2001, s. 190; J. Oniszczuk, Dobro wspólne 
Prawa polityczne mogą służyć właśnie takiemu ukształtowaniu stosunków między państwem i społeczeństwem. Aby taki cel osiągnąć, konieczna jest wiarygodna i realna reprezentacja

jako cel prawa, „Studia i prace Collegium Ekonomiczno-Społecznego SGH” 2003, z. 5, s. 186. Przyjęta koncepcja państwa - jako dobra wspólnego nakazuje państwu traktować obywatela z odpowiednim szacunkiem, gwarantować jego wolności i prawa umacniając jego zaufanie do państwa. Jednocześnie formuła ta wzywa obywatela, aby identyfikował się z państwem, odpowiednio wysoko sytuował je w hierarchii wartości i wypełniał nałożone na niego obowiązki. Por. J. Trzciński, Rzeczpospolita Polska dobrem wspólnym wszystkich obywateli, [w:] Sadownictwo administracyjne gwarantem wolności i praw obywatelskich 1980-2005, red. J. Góralczyk, R. Hauser, J. Trzciński, Warszawa 2005, s. 459-460 W doktrynie podkreśla się, że pojęcie dobra wspólnego odmiennie chcą rozumieć przedstawiciele nauki społecznej Kościoła, odmiennie liberałowie, a jeszcze inaczej komunitaryści. Por. R. Morawski, Prawa i jednostki a dobro wspólne (liberalizm versus kom unitaryzm), „Państwo i Prawo” 1988, z. 11, s. 27-29; R. Sobański, Dobro wspólne w definicji ustawy Tomasza z Akwinu, [w:] Prawo a wartości: księga jubileuszowa Profesora Józefa Nowackiego, red. I. Bobucka, Z. Tobor, Kraków 2000, s. 256. W literaturze podkreśla się, że definiowanie dobra wspólnego utrudnione jest faktem, iż termin ten osadzony jest w różnych koncepcjach filozoficznych i teoretyczno-prawnych. Nie sposób jednak dobra wspólnego identyfikować z dobrem państwa w rozumieniu konkretnego aparatu władzy, gdyż instytucja władzy publicznej są służebne wobec społeczeństwa i mają obowiązek działania dla jego dobra, a więc dla dobra wspólnego wszystkich obywateli. Por. M. Zubik, Refleksje nad „dobrem wspólnym" jako pojęciem konstytucyjnym, [w:] Prawo a polityka, red. idem, Warszawa 2007, s. 395; J. Oniszczuk, Dobro wspólne jako cel prawa, „Studia i prace Collegium Ekonomiczno-Społecznego SGH” 2003, z. 5, s. 186. Dobrem wspólnym są przy tym instytucje władzy państwowej działające według określonych procedur zapewniających tzw. sprawiedliwość proceduralną, a więc aparat państwowy, ogół organów i urzędów. Por. M. Piechowiak, Filozoficzne podstawy..., op.cit., s. 25; P. Śpiewak, W stronę wspólnego dobra, Warszawa 1998 s. 216. Dobrem wspólnym jest nie tylko działanie organów państwa, lecz także stanowione lub aprobowane prawo. Por. W. Sokolewicz, Uwagi do art. 1 Konstytucji, [w:] Konstytucja Rzeczypospolitej Polskiej. Komentarz, t. V, red. L. Garlicki, Warszawa 2007, s. 32-34. W literaturze podkreśla się, że państwo jest dobrem wspólnym w aspekcie stratyfikacji społecznej, bez względu na przynależność obywateli do różnych grup zawodowych, stan majątkowy i miejsce zajmowane w hierarchii społecznej. W aspekcie politycznym formuła dobra wspólnego zakazuje zawłaszczenia państwa przez władze polityczne, a w aspekcie religijnym nie dopuszcza do takiego wpływania Kościołów i związków wyznaniowych na władzę państwową, która byłaby niezgodna z zasadami poszanowania i autonomii wobec tych podmiotów. W końcu $\mathrm{w}$ aspekcie terytorialnym państwo jest dobrem wspólnym, bez względu na to, w którym miejscu zamieszkują je obywatele. 
interesów obywateli na różnych poziomach władzy i stworzenie możliwości działań obywatelskich. Wywiedziono, że życie prywatne i światopogląd nie mogą stanowić przedmiotu totalnej kontroli. Dla społeczeństwa niebezpieczne są manipulacje wyborami ludzi przez struktury władzy, siły polityczne, elity ekonomiczne i środki informacji. Za niedopuszczalne uznano w Podstawach nauki... zbieranie i posługiwanie się informacjami na temat wszelakich stron życia ludzie bez ich zgody. W przypadkach, gdy wymaga tego obrona Ojczyzny, względy moralności, ochrona praw i prawnych interesów obywateli, a także dążenie do zapobieżenia bądź wykrycia przestępstw, zbieranie informacji o człowieku może być dokonywanie bez jego zgody, z tym jednak, że w takich przypadkach zdobywanie i posługiwanie się informacją musi być dokonywanie współmiernie do ogłoszonych celów i w warunkach przestrzegania prawa. Pozyskiwanie i przetwarzanie danych nie może jednak poniżać godności człowieka ograniczać jego wolności i przekształcać go z podmiotu stosunków społecznych w bezwolny podmiot zewnętrznie sterowany. Szczególne niebezpieczeństwo dla wolności człowieka, twórcy Podstaw nauki... widzieli w środkach technicznych, których nie da się oddzielić od ciała człowieka, a które będą mogły być wykorzystywane dla kontroli nad osobowością.

Życie ziemskie - jak podkreślono w dokumencie - nie jest możliwe bez zaspokojenia potrzeb materialnych. Niezbędne jest jednak nadanie jasnych kryteriów moralnych prawu własności, prawu do zatrudnienia, prawu obrony przed samowolą pracodawcy, swobodzie przedsiębiorczości, prawu do godnego poziomu życia. Zauważono, że realizacja praw ekonomicznych nie powinna doprowadzać do formowania takiego społeczeństwa, w którym korzystanie z dóbr materialnych przekształca się w dominujący, a nawet jedyny cel funkcjonowania człowieka i społeczeństwa. Prawa ekonomiczne nie powinny dopuszczać do konfrontacyjnego rozwarstwienia społeczeństwa, które, bę- 
dąc sprzeczne z przykazaniem miłości bliźniego, tworzy warunki do degradacji moralnej, społeczeństwa i jednostki, rodzi alienację między ludźmi, narusza zasadę sprawiedliwości. Społeczeństwo powinno troszczyć się o ludzi, którzy nie są w stanie zabezpieczyć swoich potrzeb materialnych. Dostępność do wykształcenia i niezbędnej dla życia pomocy medycznej nie powinny zależeć od społecznej i ekonomicznej pozycji człowieka.

Twórcy Podstaw nauki... wskazali, że prawa poszczególnych osób nie mogą być niszczące dla tradycji rodzinny i funkcjonowania rozmaitych społeczności o charakterze religijnym, narodowym i socjalnym. Przez rodzinę są przekazywane tradycje religijne, układ społeczny i kultura narodowa. Współczesne prawo powinno z szacunkiem odnosić się do rodziny jako prawnego związku mężczyzny i kobiety. Musi traktować ją jako integralny organizm, broniąc przed zniszczeniem. Ochrona praw dziecka nie może negować szczególnej roli rodziców. Za niezbędne uznano poszanowanie innych praw grupowych, takich jak prawo do pokoju, prawo do otaczającego środowiska, prawo do zachowania dziedzictwa kulturalnego. Jedność i wzajemne związki obywatelskich, politycznych, ekonomicznych i społecznych, indywidualnych i grupowych praw człowieka wspiera budowę harmonijnej organizacji życia społeczeństwa, zarówno na poziomie narodowym, jak i międzynarodowym ${ }^{18}$.

18 Niezwykle delikatną kwestią jest problem czy dzieciom samodzielnie, nie za pośrednictwem rodziców, a nawet wbrew ich stanowisku, przysługuje ochrona wolności sumienia i wyznania, prawo do posiadania albo przyjmowania religii lub światopoglądu w treści art. 18 MPPOP trudno szukać wskazówek w tym względzie. Doktryna stoi na stanowisku, iż dzieci z natury rzeczy nie są zdolne do samodzielnego kierowania swoimi sprawami życiowymi. Stąd prawo musi określać „status pasywny” dziecka, czyli wskazywać, kto i w jakim zakresie jest uprawniony i zobowiązany do zajmowania się jego sprawami czyli zasady i zakres poddania władzy innych osób przede wszystkim rodziców i opiekunów. Korelatem tego uprawnienia jest obowiązek posłuszeństwa dziecka wobec rodziców. Prawo musi także określać status aktywny dziecka, zapewniający mu możliwość samodzielnego realizowania niektórych wolności i praw konstytucyjnych. Zob. L. Garlicki, Komentarz do art. 72 Konstytucji, 
W ostatniej części zwrócono uwagę na potrzebę zabezpieczenia praw Rosyjskiej Cerkwi Prawosławnej, wskazując, że wśród celów prawosławia na obecnym etapie należy wskazać: obrona prawa ludzi na swobodne wyznawanie wiary, na prowadzenie modlitw i nabożeństw, do zachowania duchowo-kulturalnych tradycji, na kierowanie się zasadami zarówno w życiu prywatnym, jak i w sferze działalności społecznej; przeciwdziałanie przestępstwom na gruncie wrogości narodowej i religijnej; ochrona osoby ludzkiej przed samowolą osób posiadających władzę, pracodawców, a także przed gwałtem i poniżeniem w rodzinie i zespole; obrona życia, wolnego wyboru i mienia ludzi w trakcie konfliktów międzyetnicznych, politycznych, ekonomicznych i społecznych; opieka duszpasterska nad żołnierzami, zachowanie ich praw i godności w warunkach działań wojennych i odbywania służby w czasie pokoju; troska

[w:] Konstytucja Rzeczypospolitej Polski, komentarz, t. III, red. L. Garlicki, Warszawa 2003, s. 4; A. Grzejdziak, Prawo do wychowania w rodzinie, [w:] Prawa $i$ wolności obywatelskie w Konstytucji RP, red. B. Banaszak, A. Preisner, Warszawa 2002, s. 473 i n. Za przyjęciem tezy, iż jest to wolność, z której korzystać mogą osoby niepełnoletnie, a więc nieposiadających zdolności do czynności prawnych, przemawia treść ust. 1 art. 18 MPPOP, gdzie wyraźnie zawarowano, że każdemu zapewnia się wolność sumienia i wyznania. Skoro wolność ta przysługuje każdemu - to także osobom niepełnoletnim, które nie osiągnęły zdolności do czynności prawnych. Warto zauważyć, że w obrębie tym mieści się również prawo do wychowania i nauczania światopoglądu niereligijnego. Pojawia się jednak problem czy statuowane przez art. 18 ust. 4 MPPOP rodzicielskie prawo do zapewnienia dzieciom wychowania oraz nauczania moralnego i religijnego, zgodnego z przekonaniami rodziców, jest skuteczne wobec wszystkich podmiotów prowadzących szkoły publiczne i niepubliczne. Innymi słowy czy rodzice mają możność żądania, aby szkoła zapewniała ich dzieciom wychowanie i nauczanie religijne zgodnie $\mathrm{z}$ ich wyborem. Z orzecznictwa Komitet Praw Człowieka wynika, że statuowane w art. 18 ust. 4 MPPOP prawo rodzicielskie nie nakłada na państwa będące stronami Paktu obowiązku zapewnienia dzieciom lekcji religii w szkołach publicznych, zgodnie z życzeniami rodziców, ale tylko wtedy, gdy szkoły publiczne nie oferują jakichkolwiek lekcji religii w swoim programie. Komitet Praw Człowieka stanął na stanowisku, że treść art. 18 MPPOP chroni nie tylko przekonania o charakterze religijnym niemające żadnego związku z religią, a więc nie tylko ateistyczne bądź teistyczne. 
o szacunek dla godności i praw ludzi znajdujących się w instytucjach społecznych i miejscach odbywania kary, ze szczególną uwagą udzielaną położeniu inwalidów, sierot, starców i drugich bezradnych ludziom; obrona praw narodów i grup etnicznych, ich religii, języków i kultur; opieka nad tymi, czyje prawa, wolność i zdrowie doznają uszczerbku z powodu działalności destrukcyjnych sekt; podtrzymanie rodziny w jej tradycyjnym rozumieniu, ojcostwa, macierzyństwa i dzieciństwa; przeciwdziałanie wciąganiu ludzi w korupcję i inne rodzaje przestępczości, a także prostytucję, narkomanię i uzależnienie od gier; troska o sprawiedliwą ekonomiczną i socjalną organizację społeczeństwa; niedopuszczenie do totalnej kontroli nad osobą ludzką, nad jej wyborem światopoglądowym i życiem prywatnym za pomocą wykorzystania współczesnych technologii i manipulacji politycznych; wychowanie w duchu szacunku do praworządności, propagowanie pozytywnego doświadczenia realizacji i obrony praw człowieka; dokonywanie ekspertyz aktów prawnych, inicjatyw ustawodawczych i działań organów władzy w celu niedopuszczenia podeptania praw i godności człowieka, pogorszenia sytuacji moralnej w społeczeństwie; uczestnictwo w społecznej kontroli nad wypełnieniem prawodawstwa, w szczególności regulującego stosunki Kościoła prawosławnego z państwem, a także za tym, jak są realizowane sprawiedliwe orzeczenia sądów.

Opracowanie przez Rosyjską Cerkiew Prawosławną Podstaw nauki społecznej tego Kościoła jawi się jako ważny dokument określający zamierzenia Kościoła Prawosławnego, zarówno w odniesieniu do państwa i polityki, jak i w pierwszym rzędzie do koncepcji praw człowieka. Nie sposób nie zauważyć, że nauka społeczna w ujęciu prawosławnym nie ma tak rozbudowanego charakteru, jak koncepcje prezentowane przez Kościół rzymskokatolicki. Podkreślić jednak wypada, że prawosławna koncepcja nauki społecznej zrodziła się znaczą- 
co później, niż koncepcja rzymskokatolicka, a z treści dokumentu można wnioskować, że ma on być remedium na szereg nierozwiązanych kwestii problemowych istniejących między Rosyjską Cerkwią Prawosławną a rosyjskim państwem i społeczeństwem. Jest też wyraźnie efektem kompromisu między ścierającymi się poglądami hierarchów.

\section{Bibliografia}

\section{Literatura}

Autonomia i sposób jej ogłaszania. Dokumenty przyjęte przez Święty i Wielki Sobór Cerkwi Prawosławnej Kreta, 18-26.06.2016 r., „Cerkiewny Wiestnik” 2016, nr 4.

Banaszak M., Historia Kościoła katolickiego, t. 3; Czasy nowożytne 1517-1758, Warszawa 1989.

Borutka T., Propedeutyka katolickiej nauki społecznej, [w:] Katolicka nauka spoteczna, red. T. Borutka, J. Mazur, A. Zwoliński, Częstochowa 1999.

Compagnoni F., Prawa człowieka. Geneza, historia i zaangażowanie chrześcijańskie, Kraków 2000.

Czekalski R., Rozwój katolickiej nauki społecznej po Soborze Watykańskim II ze szczególnym uwzględnieniem pontyfikatu Jana Pawta II, „Warszawskie Studia Teologiczna” 2011, XXIV nr 1.

Dudziak E., Kościót katolicki wobec praw człowieka. Ewolucja stanowiska, „Studia z Prawa Wyznaniowego” 2007, t. 10.

Gałkowski J. W., Jan Pawet II o godności człowieka, [w:] J. Czerkawski, Zagadnienie godności człowieka, Lublin 1994.

Garlicki L. Komentarz do art. 72 Konstytucji, [w:] Konstytucja Rzeczypospolitej Polski. Komentarz, t. III, red. L. Garlicki, Warszawa 2003. 
Głuszak T., U poczatków katolickiej nauki społecznej, „Teologia Praktyczna", 2010, nr 11.

Grzejdziak A., Prawo do wychowania w rodzinie, [w:] Prawa $i$ wolności obywatelskie w Konstytucji RP, red. B. Banaszak, A. Preisner, Warszawa 2002.

Harakas S., Kościót prawosławny wobec kwestii moralnych, [w:] Światto wiary i zdrój doświadczenia, red. K. Leśniewski, J. Leśniewska, Lublin 1999.

Juros H., Katolicka nauka spoteczna contra teologia (moralna) społeczna. Uwagi metodologiczne do Orędzia Jana Pawta II na Międzynarodowy Dzień Pokoju 1998, Europejskie dylematy i paradygmaty, Warszaw 2003.

Juros H., Wokót tożsamości katolickiej nauki społecznej, [w:] Europejskie dylematy i paradygmaty, Warszaw 2003.

Kostiuczuk J., Społeczne nauczanie Kościoła Prawosławnego, Warszawa 2018.

Kościót i prawa człowieka - dokument Papieskiej Komisji „Iustitia et Pax”, „Więź” 1978, nr 5 (241).

Majka J., Katolicka nauka społeczna, „Chrześcijańska myśl społeczna" 1988, t. II.

Majka J., Katolicka nauka spoteczna. Studium historyczno-doktrynalne, Rzym-Lublin 1987.

Matwiejuk J., Konstytucyjno-ustawowa pozycja zwiazków wyznaniowych w Federacji Rosyjskiej, Białystok 2016.

Mazurek F.J., Godność osoby ludzkiej podstawa praw człowieka, Lublin 2001.

Mazurek F.J., Praw człowieka w nauczaniu społecznym Kościota, Lublin 1991.

Morawski R., Prawa i jednostki a dobro wspólne (liberalizm versus kom unitaryzm), „Państwo i Prawo” 1988, z. 11.

Motyka K., Prawa Człowieka. Wprowadzenie, wybór źródet, Lublin 2004. 
Oniszczuk J., Dobro wspólne jako cel prawa, „Studia i prace Collegium Ekonomiczno-Społecznego SGH” 2003, z. 5.

Piechowiak M., Filozoficzne podstawy rozumienia dobra wspólnego, „Kwartalnik Filozoficzny” 2003, vol. 31, nr 2.

Piechowiak M., Konstytucyjna zasada dobra wspólnego - w poszukiwaniu kontekstu interpretacji, [w:] Dobro wspólne. Problemy konstytucyjnoprawne i aksjologiczne, red. W. Wołpiuk, Warszawa 2008.

Piechowiak M., Prawnonaturalny charakter klauzuli dobra wspólnego. Równi w prawach $i$ powinnościach wobec dobra wspólnego - Polski, [w:] „Preambuła Konstytucji Rzeczypospolitej Polskiej”, red. Zespół Prezydialny Biura TK, Warszawa 2009.

Piechowiak M., Stużebność państwa wobec człowieka i jego praw jako naczelna idea Konstytucji RP z 2 kwietnia 1997 r. - osiagnięcie czy zadanie, „Przegląd Sejmowy” 2007, nr 4 (81).

Piechowiak M., W sprawie aksjologicznej spójności Konstytucji RP. Dobro wspólne czy godność człowieka?, [w:] Jedność aksjologiczna systemu prawa w rozwijajacych sie państwach demokratycznych Europy, red. S.L. Stadniczeńko, Opole 2010

Possenti V., Katolicka nauka społeczna wobec dziedzictwa Oświecenia, Kraków 2000, s. 201.

Pyszka S., Ewolucja katolickiej nauki społecznej w latach 1891-2003, „Forum Philosophicum” 2003, nr 8.

Sobański R., Dobro wspólne $w$ definicji ustawy Tomasza z Akwinu, [w:] Prawo a wartości. Księga jubileuszowa prof. J. Nowackiego, Kraków 2000.

Sobczak J., Struktura organizacyjna Cerkwi prawostawnej, „Nowa Polityka Wschodnia” 2018, nr 4 (19).

Sobczak J., "Teren kanoniczny” Rosyjskiego Kościoła Prawostawnego a prawo do wolności sumienia i wyznania, [w:]

Europejski system ochrony praw człowieka. Inspiracja uniwer- 
salna - uwarunkowania kulturowe - bariery realizacyjne, red. J. Jaskiernia, K. Spryszak, Toruń 2016.

Sokolewicz W., Uwagi do art. 1 Konstytucji, [w:] Konstytucja Rzeczypospolitej Polskiej. Komentarz, t. V, red. L. Garlicki. Skorowowski H., Problematyka praw człowieka, Warszawa 2005.

Strzeżewski Cz., Katolicka nauka społeczna, Warszawa 1985.

Ślipko T., O współczesnej potrzebie katolicyzmu społecznego, „Annales. Ethics in Economic Life” 2005, nr 1.

Ślipko T., Ewolucja katolickiej nauki społecznej, ale jaka? „Forum Philosophicum", 2004, nr 9.

Śpiewak P., W stronę wspólnego dobra, Warszawa 1998

Tofiluk J., Autokefalia w rozumieniu kościoła prawosławnego, [w:] Autokefalie kościoła prawostawnego w Polsce, red. A. Mironowicz, U. Pawluczuk, P. Chomik, Białystok 2006. Trzciński J., Rzeczpospolita Polska dobrem wspólnym wszystkich obywateli, [w:] Sadownictwo Administracyjne gwarantem wolności i praw obywatelskich 1980-2005, Warszawa 2005.

Zdyb M., dobro wspólne w perspektywie art. 1 Konstytucji Rzeczypospolitej Polskiej, [w:] F. Rymasz, A. Jankiewicz „Trybunał Konstytucyjny księga XV-lecia”, Warszawa 2001, s. 190, Zubik M., Refleksje nad „dobrem wspólnym” jako pojęciem konstytucyjnym, [w:] Prawo a polityka, idem, ???

Баранов Н. А., Взаимодействие Церкви и государства в современной России, „Южно-российский журнац социальных наук", 2009, nr 4.

\section{Materiały}

Encyklika Pecem in terris: AAs 55 (1963). Jan XXIII, Encyklika Mater et magistra: AAS 53 (1961). Jan Paweł II, Orędzie do Organizacji Narodów Zjednoczonych w Nowym Jorku, 2 października 1979 r., [w:] Jan Pawet II. Nauczanie społeczne 1978-1979, Warszawa 1982. 
Jan Paweł II, Laborem exercens, [w:] „Dokumenty nauki społecznej Kościoła", Rzym-Lublin 1987, cz. 2.

Katechizm Kościoła Katolickiego, 1905-1912.

Kompendium nauki społecznej Kościoła, Kielce 2005.

Paweł VI, List apostolski Octogesima adveniens, 46: AAS 63 (1971).

Sobór Watykański II, Konstytucja duszpasterska o kościele w świecie wspótczesnym, Gaudium et spes, Acta Apostolicae Sedis 58, 1996, 1046.

Определение Юбилейного Архиерейского Собора «Об основах социальной концепции Русской Православной Церкви», https:/mospat.ru/archve/page/sobors/20002/384.html.

Основы социальной конщепции Русской Православной Церкви, Юбикейный Архиерейский Собор Русской Православной Церкви, Москва 2000.

Православное богословие на пороге третьего тысячелетия. Москва, 7-9 февраля 2000 г., Материалы конференции. Москва 2000, http://theolcom.ru/conferences/13pravoslavnoe-bogoslovie-na-poroge-iii-tysyacheletiya.

\begin{abstract}
Abstrakt
Dla świata prawosławnego prawa człowieka stanowią kategorię obcą i długi czas były traktowane z dystansem. Mimo to jednak w $1996 \mathrm{r}$. podjęto prace nad dokumentem, mającym określić stanowisko Cerkwi Prawosławnej w kwestiach społecznych. W dniu 19 lipca 2000 r. na posiedzeniu Świętego Synodu zostały przedstawione Podstawy spotecznej koncepcji Rosyjskiego Kościoła Prawosławnego. Dokument ten bywa mylony z późniejszymi Podstawami nauki Rosyjskiego Kościoła Prawostawnego o godności, wolności i prawach człowieka, który został zatwierdzony w dniu 26 czerwca 2008 r. przez Sobór Biskupów Rosyjskiego Kościoła Prawosławnego. W Podstawach nauki zwrócono uwagę na pojęcie godności, wolność wyboru i wolną wolę człowieka,
\end{abstract}


zauważając, że prawa człowieka przeszły długą ewolucję historyczną i nie mogą być absolutyzowane. Muszą one być zgodne z normami moralnymi i przykazaniami Boskimi. Powinny one być zrównoważone odpowiedzialnością ludzi względem siebie. Państwo jest ważnym elementem w budowaniu prawidłowych relacji społecznych, zabezpieczaniu porządku i sprawiedliwości. Człowiek nie może marnować zasobów przyrodniczych. Współczesny system praw człowieka jest rozgałęziony i rozwarstwiony, ale najważniejszym z praw jest prawo do życia. Ważna jest zasada wolności sumienia, wolność wyrażania myśli i uczuć, a także wolność twórczości i prawo do wykształcenia. Prawa poszczególnych osób nie mogą niszczyć rodziny i społeczności i charakterze religijnym, narodowym i socjalnym. Rosyjski Kościół Prawosławny uważa za konieczne zabezpieczenia swoich praw przez władze państwowe.

Słowa kluczowe: prawosławie, prawa człowieka, Rosyjski Kościół Prawosławny, wolność sumienia i wyznania, godność, państwo a kościół

\begin{abstract}
For the Orthodox world, human rights are a foreign category and have long been treated with distance. Despite this, in 1996 work has begun on a document to determine the position of the Orthodox Church on social issues. On July 19, 2000, at the Holy Synod meeting, the foundations of the social concept of the Russian Orthodox Church were presented. This document is sometimes confused with the later Foundations of the teaching of the Russian Orthodox Church on dignity, freedom and human rights, which was approved on June 26, 2008 by the Council of Bishops of the Russian Orthodox Church. The foundations of science highlighted the concept of dignity, freedom of choice and free will of man, noting that human rights have undergone a long historical evolution and cannot be absolutized. They must comply with moral standards and divine commandments. They should be balanced by people's responsibility to each other. The state is an important element in building proper social relations, securing order and justice. Man cannot waste natural resources. The modern human rights system is branched and stratified, but the most important right is the right to life. The principles of freedom of conscience, freedom of expression of thoughts and feelings, as well as freedom of creativity and the right to
\end{abstract}


education are important. Individual rights cannot destroy family, religious and national and social character. The Russian Orthodox Church considers it necessary for state authorities to secure their rights.

Keywords: Orthodoxy, human rights, Russian Orthodox Church, freedom of conscience and religion, dignity, state and church 


\title{
Bolesław Sprengel
}

\author{
Uniwersytet Mikołaja Kopernika w Toruniu \\ ORCID ID: https://orcid.org/0000-0003-3238-8305
}

\section{Przestępczość Azjatów w Polsce}

W ostatnich dekadach powstaje coraz więcej prac na temat przestępczości związanej z migracją. Z reguły dotyczą one współczesności ${ }^{1}$. W 1990 r. opublikowana została praca Ireny Rzeplińskiej$^{2}$. Potem kolejne, dopiero w 2015 r. stała się przedmiotem paniki moralnej ${ }^{3}$. Bernard Wiśniewski i Dariusz Podleś uważają nielegalną migrację do najważniejszych zagrożeń bezpieczeństwa publicznego ${ }^{4}$. Z kolei Justyna Zając zalicza nielegalną migrację do takich zagrożeń, jak przestępczość zorganizowana i terroryzm ${ }^{5}$. Podobnie problem postrzega Witold Pokruszyński, twierdząc,

1 Pewnym wyjątkiem jest artykuły B. Sprengla, Migracja z Polski a przestępczość, [w:] Społeczna przestrzeń Polaków żyjacych $w$ diasporze, red. idem, Poznań 2008; idem, Polsko-niemieckie stosunki stużb policyjnych w okresie międzywojennym, [w:] Spotkania polsko-niemieckie, red. D. Kawa, Toruń 2011.

2 Patrz też m.in. B. Sprengel, Policja a migracja, [w:] Bezpieczeństwo państwa a procesy migracyjne, red. L. Kacprzak, J. Knopek, Piła 2008; G. Piechowiak, Przestępczość na emigracji na przykładzie polskiej emigracji zarobkowej we Wtoszech w latach 90. XX wieku, [w:] idem.

3 D. Woźniakowska-Fajst, Cudzoziemcy jako sprawcy przestępstw przeciwko życiu i zdrowiu, [w:] Przestępczość cudzoziemców. Aspektu prawne, kryminologiczne i praktyczne, red. W. Klaus, K. Laskowska, I. Rzeplińska, Warszawa 2017, s. 39.

4 B. Wiśniewski, D. Podleś, Zagrożenia bezpieczeństwa publicznego, „Biuletyn Centrum Szkolenia Straży Granicznej” 2004, nr 28, s. 142-150.

5 J. Zając, Bezpieczeństwo państwa, [w:] Bezpieczeństwa państwa. Wybrane problemy, red. K.A. Wojtaszczyk, A. Materska-Sosnowska, Warszawa 2009, s. 22. 
że migracjom może towarzyszyć handel bronią i narkotykami ${ }^{6}$. Również Wiesław Pływaczewski uważa, że: „z samej swej istoty zjawisko nielegalnego przemieszczenia się ludzi narusza utrwalony ład światowy i systemy prawne poszczególnych państw. Nie ulega też wątpliwości, że wielu nielegalnych przybyszów zasila szeregi organizacji przestępczych"7. Krzysztof M. Księżopolski i Przemysław Deszczyński zwracają uwagę na znaczenie migracji dla bezpieczeństwa ekonomicznego państwa ${ }^{8}$. Na szczególną uwagę zasługują badania Katarzyny Laskowskiej ${ }^{9}$.

Źródłami do badań przestępczości Azjatów w Polsce są m.in. raporty o stanie bezpieczeństwa państwa, raporty roczne Polskiej Służby Konsularnej, dane KG Policji, KG SG, Ministerstwa Sprawiedliwości W statystykach policyjnych z reguły jest więcej podejrzanych niż prawomocnie skazanych. Pisze o tym m.in. I. Błachut w książce Problemy zwiąane $z$ pomiarem przestępczości ${ }^{10}$. Inaczej sytuacja wyglądała w przypadku poważniejszych przestępstw kryminalnych. Z badań wynika, że w obowiązującym do początku 2013 r. policyjnym systemie ewidencji statystycznej „Temida” nie było obowiązku wpisywania obywatelstwa podejrzanego. Wprowadzono go dopiero w obowiązującym obecnie KSIP, co zmusza to ostrożniejszego traktowania danych policyj-

6 W. Pokruszyński, Uwarunkowanie wspótczesnego bezpieczeństwa międzynarodowego, Szczytno 2006, s. 59.

7 W. Pływaczewski, Relacje pomiędzy zjawiskiem nielegalnej imigracji a przestępczościq oraz innymi przejawami zachowań patologicznych $w$ różnych ich postaciach, [w:] Polska w Schengen, red. M. Zdanowicz, Białystok 2009, s. 227-228.

8 K.M. Księżopolski, Wptyw migracji na bezpieczeństwo ekonomiczne państwa, [w:] Bezpieczeństwo państw..., op.cit., s. 79-75; P. Deszczyński, Migracje zewnętrzne a bezpieczeństwo gospodarcze państw, [w:] ibidem, s. 93-108.

9 Patrz np. K. Laskowska, Rosyjskojęzyczna przestępczość zorganizowana. Studium kryminologiczne, Białystok 2006.

10 I. Błachut, Problemy związane z pomiarem przestępczości, Warszawa 2007, s. 250-251. 
nych. Także danych sądowych nie można traktować zawsze jako pewnych, np. w Krajowym Rejestrze Sądowym zdarzają się błędny we wskazaniu narodowości skazanego ${ }^{11}$.

Według J. Piskorskiego przestępczość cudzoziemców w Polsce ma przede wszystkim podłoże ekonomiczne. W latach 1920-1940 przestępczość cudzoziemców badano w USA. Później to zainteresowanie tam zmalało, a wzrosło w Europie Zachodniej. Początkowo miała związek z napływem tam tzw. quest-workers ${ }^{12}$. Polscy w Niemczech są na czwartym miejscu wśród cudzoziemców-przestępców ${ }^{13}$. Według kryminologów niemieckich część imigrantów-przestępców przyjeżdża w celu zdobycia pieniędzy z przestępstwa. W $2003 \mathrm{r}$. w Polsce przestępczość cudzoziemców nie była problemem politycznym ${ }^{14}$.

Do transformacji ustrojowej w 1989 r. przestępczość cudzoziemców w Polsce miała charakter epizodyczny. Zjawisko to nasiliło się po przemianach ustrojowych. Od 1989 r. nastąpił jego 10-krotny wzrost i wynosi średnio około $1 \%^{15}$. Po $1989 \mathrm{r}$. wzrosła liczba przyjazdów do Polski w 1990 r. - 18 mln 211 tys., 1991 r. -36 mln 846 tys., 1996 r. -87 mln 349 tys., 2002 r. 50 mln 734 tys. ${ }^{16} \mathrm{Na}$ koniec $2013 \mathrm{r}$. wśród cudzoziemców obywatele Wietnamu stanowili 11\%, Chińskiej Republiki Ludowej $-4 \%$, Republiki Armenii - 4\%, Turcji - 2\%, Indii - 2\%, Korei Południowej $-1,5 \%{ }^{17}$.

11 D. Woźniakowska-Fajst, Cudzoziemcy.., op.cit., s. 43.

12 S. Hoc, Przestępczość cudzoziemców ze szczególnym uwzględnieniem Warszawy i województwa mazowieckiego, [w:] Przestępczość i zjawiska patologiczne w województwie mazowieckim, red. F. Prusak, Warszawa 2003, s. 38-39.

13 Ibidem, s. 39.

14 Ibidem, s. 40.

15 Ibidem, s. 30

16 Ibidem, s. 31.

17 I. Rzeplińska, J. Włodarczyk-Madejska, Przestępczość cudzoziemców w Polsce - na podstawie policyjnych statystyk przestępczości, [w:] Przestęp- 
W 2001 r. w Polsce było podejrzanych 7061 cudzoziemców, w tym 494 Ormian, 462 Niemców $^{18}$. Na terenie Warszawy w 2001 r. 777 cudzoziemców było podejrzanych o popełnienie przestępstw, w tym 230 Ukraińców, 132 Ormian, 59 Białorusinów, 57 Rosjan, 37 Wietnamczyków, 20 Bułgarów, 20 z pozostałych krajów azjatyckich, 19 Mongołów, 18 Rumunów ${ }^{19}$. W latach 2004-2012 policjanci postawili zarzuty 1394 obywatelom Armenii ${ }^{20}$. Na początku lat 90. organy ścigania z rejonu pogranicznego nie były przygotowane kadrowo i technicznie na wzrost przestępczości. W Słubicach było tylko ośmiu doświadczonych prokuratorów. Jednym z powodów wzrostu przestępczości w rejonie przygranicznym był niekontrolowany napływ nielegalnych uchodźców. Brak pieniędzy był powodem popełniania przestępstw. Jednym z przyczyn ograniczenia przestępczości mogło być wprowadzenie systemu wizowego, możliwości przyjazdu, rygorystyczne przestrzeganie ustawy z 29 marca 1963 r. o cudzoziemcach (Dz.U. 1992, nr 7, poz. 30 z późn. zm.). Ograniczenia takiego pobytu w ośrodkach stosowano na początku lat 90 . w stosunku do obywateli Indii i Pakistanu. Było to kłopotliwe, bo nie znali języka. Nie mieli dokumentów, a ich placówki konsularne i dyplomatyczne odmawiały im pomocy ${ }^{21}$.

Według danych Straży Granicznej najczęściej do Polski nielegalnie przybywają z Azji Kurdowie, Czeczeni, obywatele Sri

czość cudzoziemców. Aspekty prawne, kryminologiczne i praktyczne, red. W. Klaus, K. Laskowska, I. Rzeplińska, Warszawa 2017, s. 19.

18 S. Hoc, Przestępczość..., op.cit., s. 34.

19 Ibidem, s. 35.

20 I. Rzeplińska, J. Włodarczyk-Madejska, Przestępczość..., op.cit., s. 21.

21 J. Szudrowicz, Struktury, rozmiary i zwalczanie przestępczości granicznej i przygranicznej w okręgu dziatania prokuratury Rejonowej w Stubicach w latach 1990-1995, [w:] Przestępczość przygraniczna, t. 1: Reakcje praktyków, red. A.J. Szwarc, G. Wolf, Frankfurt n/Odrą-Słubice-Poznań 2001, s. 131-132. 
Lanki, Afganistanu, Armenii i Bangladeszu22. Na początku lat 90. SG odnotowała nielegalne przekraczanie granicy polskiej z Litwy i Ukrainy drogą powietrzną. Na przykład w 1993 r. zatrzymano 7 Pakistańczyków i 22 Hindusów przerzuconych do Polski helikopterem wojskowym ${ }^{23}$. W 1994 r. podczas próby zorganizowanego przekroczenia granicy zatrzymano: 824 obywateli Armenii, 226 - Indii, 59 - Afganistanu, 53 - Iraku, 49 - Pakistanu i 46 - Sri Lanki. W 1995 r. odnotowano 52 próby zorganizowanego przekraczania granicy przez grupy liczące co najmniej 10 osób. Najczęściej przez Azjatów - 35 grup. Zatrzymano m.in. 81 Ormian, 82 Afgańczyków, 62 Hindusów, 61 Irakijczyków, 61 Irańczyków, 52 Lankijczyków, 41 Pakistańczyków, 22 Bangijczyków ${ }^{24}$. W ciągu pięciu lat liczba zatrzymanych obywateli państw azjatyckich, nie licząc azjatyckich republik WNP, wzrosła do 60\%. W latach 1994-1995 wzrosła liczba nielegalnych przekroczeń granicy przez Azjatów w zorganizowanych grupach z 65 do 126 liczących od 10 do 90 osób, w tym Azjatów z 16 do $49^{25}$.

W 1995 r. odnotowano 52 próby zorganizowanego przekraczania granicy przez grupy liczące co najmniej 10 osób. Najczęściej przez Azjatów - 35 grup. Zatrzymano m.in. 81 Ormian, 82 Afgańczyków, 62 Hindusów, 61 Irakijczyków, 61 Irańczyków, 52 Lankijczyków, 41 Pakistańczyków, 22 Bangijczyków ${ }^{26}$. W ciągu pięciu lat liczba zatrzymanych obywateli państw azjatyckich

22 J.R. Truchan, Jednostki specjalne Policji i Straży Granicznej w ochronie wschodniej granicy Polski, Szczytno 2014, s. 52.

23 M. Perkowska, Przestępczość graniczna w ujęciu fenomenologicznym, [w:] Bezpieczeństw granic Rzeczypospolitej Polskiej, red. A. Konopka, G. Sobolewski, Białystok 2011, s. 199.

24 M. Kamiński, Przestępczość przygraniczna $w$ rejonie środkowego odcinka polskiej granicy zachodniej, [w:] Przestępczość przygraniczna, t. 1: Relacje praktyków, red. A.J. Szwarc, G. Wolf, Frankfurt n/Odrą-Słubice-Poznań 2001, s. 204-206.

25 Ibidem, s. 201.

26 Ibidem, s. 204-205, 206. 
nie licząc azjatyckich republik WNP wzrosła do 60\%. W latach 1994-1995 wzrosła liczba nielegalnych przekroczeń granicy przez Azjatów w zorganizowanych grupach z 65 do 126 liczących od 10 do 90 osób, w tym Azjatów z 16 do 49²7. W 2002 r. Straż Graniczna zatrzymała 383 Afgańczyków, 149 Chińczyków, 146 Wietnamczyków, 113 Hindusów. Pod zarzutem działania w zorganizowanych grupach zatrzymano 229 Chińczyków i 218 Hindusów ${ }^{28}$. Ten gwałtowny wzrost liczby Afgańczyków wynikał m.in. z ogłoszonej w tym roku abolicji dla cudzoziemców nielegalnie przebywających w Polsce ${ }^{29}$. Z czasem coraz więcej nielegalnych imigrantów było przerzucanych do Polski przez zorganizowane grupy przestępcze. Organizowały transport, kryjówki i punkty etapowe w krajach tranzytowych znajdujących się na szlaku do UE. W lipcu 2017 r. SG zatrzymała 7 członków Wisły Kraków za przemyt kilkuset imigrantów z Syrii, Iraku, Afganistanu i Pakistanu do krajów Europy Zachodniej, biorąc za każdego od 300 do 1000 euro $^{30}$.

Należy pamiętać o dekryminalizacji nielegalnego przekroczenia granicy na mocy ustawy z 22 kwietnia 2005 r., która weszła w życie 24 sierpnia 2005 r. (art. 264 par. 1 k.k.). W 2005 r. zatrzymano 325 Wietnamczyków, 70 Ormian, 66 Chińczyków.

Łącznie w latach 2006-2014 zatrzymano 109 obywateli Armenii na granicy wewnętrznej 109 i 313 - na zewnętrznej, 15 Kazachstanu na granicy wewnętrznej i 20 na granicy zewnętrznej, 44 Afgańczyków na wewnętrznej, a na zewnętrznej - 101,

27 Ibidem, s. 201.

28 Ibidem, s. 32.

29 M. Perkowska, Dynamika i struktura przestępczości granicznej cudzoziemców w Polsce na podstawie danych statystycznych Komendy Głównej Straży Granicznej, [w:] Przestępczość cudzoziemców: aspekty prawne, kryminologiczne i praktyczne, red. W. Klaus, K. Laskowska, I. Rzeplińska, Warszawa 2017, s. 124-125.

30 L. Szymanowski, To nie kibice, to bandyci, „Angora”, 17.12.2017, nr 51, s. 33 . 
13 - Azerbejdżanu na granicy wewnętrznej i 6 na zewnętrznej, 236 - Chin na granicy wewnętrznej i 121 na zewnętrznej, 40 Mongolii na granicy wewnętrznej 40 i 33 na zewnętrznej, 113 - Pakistanu na granicy wewnętrznej i 142 na zewnętrznej, 25 Sri Lanki na granicy wewnętrznej i 78 na zewnętrznej - 78, 59 Turków na granicy wewnętrznej, a 89 na zewnętrznej ${ }^{31}$. W 2006 r. zatrzymano 190 Wietnamczyków, 69 Chińczyków, 48 Ormian. W 2007 r. zatrzymano 103 Wietnamczyków, 54 Chińczyków, 45 Gruzinów, 44 Ormian.

Od 2008 r. w Polsce rejestrowana jest nielegalna migracja tylko na zewnętrznych granicach $\mathrm{UE}^{32}$. W $2008 \mathrm{r}$. zatrzymano 188 Wietnamczyków, 74 Chińczyków i 46 Ormian. W 2009 r. zatrzymano 273 Gruzinów, 137 Wietnamczyków, 69 Chińczyków, 36 Ormian. Na uwagę zasługuje wzrost podejrzanych w 2009 r., po oficjalnym zakończeniu w 2008 r. tzw. wojny pięciodniowej z Rosją. W 2010 r. zatrzymano 88 Gruzinów, 67 Turków, 58 Wietnamczyków i 18 Afgańczyków. W 2011 r. zatrzymano 109 Turków, 48 Afgańczyków i 44 Wietnamczyków, 9 Syryjczyków i 3 Pakistańczyków. W 2012 r. zatrzymano 140 Pakistańczyków, 108 Syryjczyków, 101 Wietnamczyków, 25 Ormian i 24 Chińczyków. W 2013 r. zatrzymano 67 Wietnamczyków, 41 Ormian, 17 Chińczyków. Wyraźny wzrost w 2012 r. wynikła z ogłoszonej w tym roku przez polskie władze abolicji dla cudzoziemców nielegalnie przebywających w Polsce $^{33}$.

W 2017 r. SG zatrzymała podczas nielegalnego przekraczania granicy m.in. 143 obywateli Turcji, 107 - Wietnamu, 103 - Syrii, 69 - Indii, 67 - Armenii, 55 - Iraku, 43 - Pakistanu,

31 M. Perkowska, Dynamika..., op.cit., s. 124-125.

32 P. Lubiewski, Wpływ nielegalnej imigracji na bezpieczeństwo wewnętrzne Rzeczypospolitej Polskiej, [w:] Meandry bezpieczeństwa wewnętrznego państwa, red. A. Babiński, Szczytno 2017, s. 166.

33 M. Perkowska, Dynamika..., op.cit., s. 124-127. 
34 - Chin, 33 - Uzbekistanu, 32 - Afganistanu, 31 - Iranu, po 25 - Azerbejdżanu i Bangladeszu, 22 - Tadżykistanu, 17 Kirgistanu, 15 - Libanu, 13 - Kazachstanu, po 11 - Izraela i Jemenu, 8 - Mongolii, 7 - Palestyny, 6 - Jordanii, po 4 - Arabii Saudyjskiej i Nepalu, 2 - Sri Lanki, po 1 - Filipin, Tajwanu, Korei Południowej, Indonezji, Singapuru i Omanu.

W 2018 r. w podobnych okolicznościach SG zatrzymała: 212 obywateli Wietnamu, 152 - Turcji, 85 - Syrii, 78 - Indii, 66 - Iraku, 54 - Iranu, 51 - Nepalu, 36 - Afganistanu, 35 Chin, 30 - Tadżykistanu, 29 - Armenii, 27 - Pakistanu, po 23 - Azerbejdżanu i Bangladeszu, 18 - Uzbekistanu, 17 - Kirgistanu, 10 - Mongolii, 8 - Sri Lanki, po 7 - Libanu, Palestyny i Tajlandii, 12 - Kazachstanu, 5 - Filipin, 3 - Jordanii, po 2 Izraela, Arabii Saudyjskiej i Korei Południowej, po 1 - Tajwanu, Singapuru, Laosu, Japonii i Indonezji. W 2018 r. przez granicę polsko-litewską przejechała skoda. Kierowca nie dał się złapać pogranicznikom i uciekł, ale wpadł do rowu. W środku znajdowało się 10 nielegalnych imigrantów z Wietnamu. Przekazano ich Litwinom ${ }^{34}$. Rano 8 stycznia 2018 r. KWP we Wrocławiu ujawniła, że na jednym z parkingów przy autostradzie A-4 zatrzymano dwóch nastolatków w wieku 15 i 18 lat z Afganistanu bez dokumentów. Okazało się, że w ciągu 9 dni dotarli do Polski wędrując m.in. przez Pakistan, Iran, Turcję, Bułgarię, Serbię, Rumunię, Węgry i Słowację. Podróżowali pieszo i autostopem $^{35}$. W listopadzie 1918 r. dyżurny komendy MO w Myszkowie został powiadomiony, że na teren jednej z miejscowych firm wjechał tir kierowany przez Serba, który usłyszał w przyczepie rozmowy i powiadomił ochronę. Przybyły na miejsce

34 Good morning. Vietnam 10, „Angora”, 30.09.2018, nr 39, s. 34.

35 Pieszo i autostopem przemierzyli dziewięć państw - policjanci zatrzymali dwóch nastolatków z Afganistanu, http://www.policja.pl/pol/aktualnosci/153393.Pieszo-i-autostopem-przemierzyli-9-panstw-policjanci-zatrzymali-dwoch-nastolatko.html [dostęp: 9.01.2018]. 
patrol znalazł w przyczepie czterech nielegalnych imigrantów z Afganistanu ${ }^{36}$.

Liczba Azjatów zatrzymanych na polskiej granicy nie wynika tylko z liczby osób zamierzających nielegalnie dostać się do Polski, ale także np. w aktywności służby granicznej państwa sąsiedniego. Na przykład według agencji Frontex w 2012 r. zmniejszyła się skuteczność działania białoruskiej straży granicznej3. Najwięcej podejrzanych na lotniczym przejściu granicznym ujawnia się m.in. obywateli Wietnamu i Pakista$\mathrm{nu}^{38}$. Przez Ukrainę wiedzie kilka ważnych szlaków nielegalnej migracji: wietnamski, afgański, indyjsko-pakistański, chiński, kurdyjski, czeczeński ${ }^{39}$. Według informacji przekazanych przez funkcjonariuszy Straży Celnej w Białymstoku przemytem ludzi hurtowych ilości towarów zajmują się zorganizowane grupy przestępcze wykorzystujące do tego różne środki transportu, m.in. samochody ciężarowe, pociągi osobowe i towarowe, statki i samoloty ${ }^{40}$. Przemytem na dużą skalę migrantów z państw azjatyckich i afrykańskich zajmują się międzynarodowe zorganizowane grupy przestępcze. Ich ośrodki znajdują się najczęściej w krajach byłego ZSRR, Azji południowej i na Bliskim Wschodzie. Skład tych grup wynika z podziału zadań. Posiadają one nowoczesny sprzęt i broń. Podczas przekraczania granic posługują się sprzętem optyczno-fotograficznym, łodziami pneumatycznymi, sprzętem oświetleniowym, narzędziami do cięcia metalu. Są hermetyczne, często składają się członków

36 Nielegalni imigranci w ciężarówce z kartonami, http://www.policja. pl/pol/aktualnosci/166251.Nielegalni-imigranci-w-ciezarowce-z-kartonami. html [dostęp: 14.11.2018].

37 M. Perkowska, Dynamika..., op.cit., s. 126.

38 Ibidem, s. 128.

39 M. Pietras-Eichberger, Wybrane aspekty bezpieczeństwa granicy polsko-ukraińskiej, [w:] Bezpieczeństwo granic Rzeczpospolitej Polskiej, red. A. Konopka, G. Sobolewski, Białystok 2011, s. 161.

40 J.R. Truchan, Jednostki..., op.cit., s. 58. 
rodzin. Organizują nielegalne przekraczanie granic, obserwację służb granicznych, instruują jak się przemycone osoby mają zachować $\mathrm{z}$ razie wpadki ${ }^{41}$.

Azjaci są zatrzymywani także podczas prób nielegalnego przedostania się z Polski do innego kraju UE. Dnia 15 grudnia 2009 r. około 150 uchodźców czeczeńskich i gruzińskich usiłowało pociągiem relacji Wrocław-Drezno wydostać się z Polski. Wcześniej złożyli skargi nas złe traktowanie w polskich ośrodkach. W Legnicy część z nich wyszła na tory. Pozostali zostali w pociągu i wywiesili transparenty. Negocjacje nie przyniosły efektu ${ }^{42}$.

W latach 2004-2012 obywatele Armenii najczęściej byli w Polsce podejrzani o popełnienie przestępstw przewidzianych w art. 115-119 ustawy z 4 lutego 1994 r. o oprawie autorskim i prawach pokrewnych, czyli przywłaszczenie praw autorskich, rozpowszechnianie cudzego utworu bez uprawnień, utrwalanie utworu bez uprawnień, rozpowszechnianie utworu w postaci wideogramu oraz utrudniania kontroli. Dopuszczali się także obrotu towarami oznaczonymi podrobionymi znakiem towarowym (art. $305 \$ 1-2$ ustawy z 30 czerwca 2000 r., czyny z art. $178 \mathrm{a} \$ 1$ k.k., czyny z art. $63 \mathbb{\$} 1-3$ k.k.s., $64 \mathbb{\$} 1$ k.k.s., $65 \$ 1-3$ k.k.s. ${ }^{43}$

W marcu 2019 r. Centralne Biuro Śledcze Policji, wspólnie ze Strażą Graniczną i Podlaskim Zamiejscowym Departamentem do Spraw Przestępczości Zorganizowanej i Korupcji Prokuratury Krajowej rozbita została zorganizowana grupa przestępcza. Zatrzymano 13 podejrzanym, w tym 13 Polaków i 3 Ukraińców. W realizacji sprawy uczestniczyło ponad 100 funkcjonariuszy. Przeszukano kilkadziesiąt miejsc. Ustalono, że członkowie gru-

41 Ibidem, s. 198.

42 J. Stawnicka, Dyskurs o bezpieczeństwie z perspektywy lingwosecuritologii, Katowice 2016, s. 90.

43 I. Rzeplińska, J. Włodarczyk-Madejska, Przestępczość..., op.cit., s. 26-27. 
py pomogli ponad 500 cudzoziemcom zalegalizować swój pobyt w Polsce. Wśród tych osób byli także Azjaci ${ }^{44}$.

Azjaci sporadycznie dopuszczają się w Polsce najpoważniejszych zbrodni zabójstwa. W latach 2004-2014 r. skazano obywateli Armenii za siedem zabójstw. W tych samych latach także dwóch obywateli Turcji oraz po jednym obywatelu Izraela i Kirgistanu za zabójstwo. W latach 2006 i 2009 skazano obywateli Armenii za zabójstwo przy pomocy materiałów wybuchowych i w 2013 r. za zwykłe zabójstwo ${ }^{45}$. Ormianin Harout H., przyjechał do Polski z rodzicami jako dziecko. Ukończył tylko gimnazjum, ale nie miał zawodu. Sięgał po marihuanę i mefedron oraz grał hazardowo. Gdy dorósł i związał się z kobietą, z którą miał dziecko. Pod wpływem narkotyków, aby zdobyć pieniądze na prostytutkę, zabił nożem taksówkarza. Skazany został na dożywotnie pozbawienie wolności ${ }^{46}$. Dnia 23 grudnia 2018 r. został zatrzymany pod zarzutem zabójstwa 29-letni Jakob Nelson K. ze stanu Kerala w południowo-wschodnich Indii. W Polsce pracował jako spawacz. Ofiarą był pracujący z nim obywatel Egiptu. Mniej groźnie ranił dwóch swoich rodaków ${ }^{47}$. W latach 2004-2014 trzej obywatele Kazachstanu zostali skazani za zabójstwa ${ }^{48}$, m.in. w latach 2004 i 2008 . W 2008 r. czyn popełniono pod wpływem silnego wzburzenia ${ }^{49}$. Sprawcą był 37-letni Oleg G., który z żoną i kilkuletnią córką przyjechał do Polski ze względu na polskie pochodzenie jego żony i skorzystał z prawa do repatriacji. Oleg G. miał średnie wykształcenie

44 Akcja CBŚP i SG. Rozbity gang ułatwiajacy nielegalny pobyt cudzoziemcom w Polsce, http://policja.pl/pol/aktualnosci/170456.Akcja-CBSP-i-SG-Rozbity-gang-ulatwiajacy-nielegalny-pobyt-cudzoziemcom-w-Polsce. html [dostęp: 6.03.2019].
45 D. Woźniakowska-Fajst, Cudzoziemcy..., op.cit., s. 46-47.
46 Ibidem, s. 50.
47 S. Brzozowski, Krwawe curry, „Reporter” 2019, nr 12, s. 37-38.
48 D. Woźniakowska-Fajst, Cudzoziemcy..., op.cit., s. 47.
49 Ibidem, s. 46. 
i w Kazachstanie był pomocnikiem maszynisty. W Polsce miał trudności z uzyskaniem pracy i zatrudnił się jako pracownik fizyczny. Natomiast jego żona podjęła studia. Poznała mężczyznę, z którym zaczęło ją łączyć uczucie, a męża okłamywała. Gdy Oleg G. dowiedział się, że żona ma zamiar opuścić go, wówczas Oleg G. zadał temu mężczyźnie kilka ciosów nożem, ale udało się go uratować. Skazany został na dwa lata pozbawienia wolności ${ }^{50}$. W latach 2004-2014 zostało skazanych trzech Wietnamczyków za trzy zabójstwa ${ }^{51}$. Za takie same czyny skazano dwóch obywateli Pakistanu i jednego z Uzbekistanu ${ }^{52}$.

Częściej Azjaci dopuszczali się mniej drastycznych czynów przeciwko zdrowiu. W latach 2004-2014 obywatele Armenii dokonali 5 ciężkiego uszczerbku na zdrowiu, w tym także czynu, którego wynikiem była śmierć człowieka, ale też nieumyślnego ${ }^{53}$. W tych samych latach udział obywateli Armenii wśród cudzoziemców - uczestników bójek i pobić stanowił $8 \%{ }^{54}$, a obywatel Korei Południowej Youla H.B., 27-letni inżynier odpowiadał w polskiej firmie za przestrzeganie przepisów BHP, został skazany za spowodowanie jednego ciężkiego uszczerbku na zdrowiu ${ }^{55}$. Sprawa dotyczyła pracownicy, która w wyniku wypadku doznała trwałego kalectwa ręki ${ }^{56}$. W tych samych latach obywatele Mongolii dokonali drugiego ciężkiego uszczerbku na zdrowiu, w tym trybu kwalifikowanego, czego wynikiem była śmierć człowieka ${ }^{57}$. W latach 2004-2012 Turcy najczęściej byli podejrzani o czyny z art. $278 \mathbb{\$} 1$ i 3 k.k. (kradzież rzeczy cu-
50 Ibidem, s. 50.
51 Ibidem, s. 46.
52 Ibidem, s. 46-47.
53 Ibidem, s. 55, 56.
54 Ibidem, s. 61.
55 Ibidem, s. 55.
56 Ibidem, s. 58.
57 Ibidem, s. 55, 56. 
dzej) $)^{58}$. W latach 2004-2014 jeden obywatel Uzbekistanu i Wietnamu dokonali ciężkiego uszczerbku na zdrowiu. W latach 2042014 także Turcy byli sprawcami pięciu ciężkich przypadków uszczerbku na zdrowiu, w tym również trybu kwalifikowanego, czego wynikiem była śmierć człowieka. W latach 2004-2014 obywatel Wietnamu dokonał ciężkiego uszczerbku na zdrowiu ${ }^{59}$.

Azjaci są też sprawcami przestępstw gospodarczych. W latach 60. i 70. XX w. pojawili się w Polsce studenci z państw demokracji ludowej, m.in. z Wietnamu i Syrii. Byli dobrze wykształceni i nie stwarzali problemów prawnych. Część wyjechała do Wietnamu po zakończeniu wojny, cześć pozostała ${ }^{60}$. Obecnie w Polsce jest ponad 300 tys. Wietnamczyków. Większość prowadzi działalność legalną w handlu, gastronomii i rzemiośle. Pracują tam także nielegalni imigranci. W latach 90. kradziono impulsy telefoniczne. To była specjalność cudzoziemców, m.in. Wietnamczyków, którzy w wynajętych mieszkaniach urządzali centrale do łączności międzynarodowej. Ich klientami byli azjatyccy handlarze, w ten sposób przez telefon z Chin zamawiali towar. Jak przyszedł rachunek za telefon wynajmujący mieszkanie znikali. Wśród Wietnamczyków w Polsce rozwijała się przestępczość zorganizowana, tzw. mafia wietnamska zajmująca się wymuszaniem haraczy, kradzieżami, korupcją, prostytucją, wymuszeniami, przestępczością porachunkową. Jest ściśle związana z przestępczością zorganizowaną w państwach zachodnich. W Polsce prała pieniądze zarabiane $w$ innych krajach. Ponadto zmonopolizowali tłoczenie pirackich płyt CD z programami komputerowymi i nagraniami muzycznymi, produkcję odzieży sportowej, butów, zwłaszcza podróbek znanych marek. Rozprowadzano przez Wietnamczyków i kupców z byłego ZSRR.

\footnotetext{
58 I. Rzeplińska, J. Włodarczyk-Madejska, Przestępczość..., op.cit., s. 27.

59 D. Woźniakowska-Fajst, Cudzoziemcy..., op.cit., s. 55, 56.

60 Ibidem, s. 38.
} 
Roczna wartość tych przedsiębiorstw przekraczała 300-400 mln dolarów ${ }^{61}$. Wietnamczycy rocznie wywożą z Polski kilkadziesiąt mln dolarów w gotówce. Ich grupy przestępcze należą do najbardziej hermetycznych, a tym samym są trudne do zwalczania. Były napady na samochody, pociągi, np. 23 października 1994 r. na stacji Warszawa Wschodnia relacji Moskwa-Bruksela do pociągu wtargnęło siedmiu lub ośmiu rosyjskojęzycznych napastników, którzy grożąc pobiciem i śmiercią żądali pieniędzy. Po napadzie pasażerowie prosili policjantów o powiadomienie ambasady rosyjskiej. Tego odmówiono i zablokowano odjazd pociągu. Rosyjski MSZ zażądał od władz polskich m.in. przeproszenia i ukarania winnych. Premier W. Czernomyrdin odwołał wizytę w Warszawie. Dopiero w 2003 r. skazano Ukraińca Władysława S. za udział w napadzie. Był on już w 2002 r. skazany za udział w zorganizowanej grupie przestępczej ${ }^{62}$.

W latach 2004-2012 byli podejrzani o popełnienie około 100 przestępstw, takich jak kradzieże (art. 178a $\$ 1$ k.k., przekupstwo - art. 229 \$ 3-4 k.k., czyny z art. 305 ust. 1 i 2 ustawy Prawo własności przemysłowej oraz czyny przewidziane w art. 264 \$ 1-3 k.k., czyli obowiązujące wówczas nielegalne przekroczenie granicy ${ }^{63}$. W czerwcu 2003 r. w Warszawie policjanci zatrzymali Van Diep D., obywatela Wietnamu, poszukiwanego międzynarodowym listem gończym, wystawionym przez policję niemiecką, podejrzanego o udział w zorganizowanej grupie przestępczej o charakterze zbrojnym, dokonanie zabójstw m.in. w Berlinie. Handlował na stadionie $10-$ lecia $^{64}$. W listopadzie 2008 r. policjanci z Komendy Stołecznej Policji zatrzymali 41-letnią Kim Chi V i towarzysząca jej 31-letnią Thanh Ha N. pod zarzutem usiłowania wyłudzenia z banku 80 tys. zł. Starsza

\footnotetext{
61 S. Hoc, Przestępczość..., op.cit., s. 37-38.

62 Ibidem, s. 36-37.

63 I. Rzeplińska, J. Włodarczyk-Madejska, Przestępczość..., op.cit., s. 27.

64 S. Hoc, Przestępczość..., op.cit., s. 41.
} 
z nich do wniosku kredytowego dołączyła sfałszowane dokumenty o zatrudnieniu. W czasie przeszukania mieszkania jednej z nich policjanci zabezpieczyli 100 tys. zł i dokumenty bankowe. Sprawę ujawnili pracownicy banku, którzy natrafili na nieprawidłowości w złożonych dokumentach ${ }^{65}$.

Dnia 3 stycznia 2019 r. krakowscy policjanci zwalczający przestępczość gospodarczą podczas zasadzki w jednej z galerii handlowych zatrzymali dwóch obywateli Chin w wieku 43 i 31 lat pod zarzutem skimmingu bankomatowego. Podejrzani są o zamontowanie na jednym $\mathrm{z}$ bankomatów tzw. nakładki do skanowania paska magnetycznego z numerem konta i kamerkę do rejestrowania numeru PIN. Przy jednym z zatrzymanych policjanci znaleźli część urządzeń do kopiowania danych. W ich pokoju hotelowym zabezpieczyli dwa laptopy i cztery dyski zewnętrzne oraz cztery zestawy do skimmingu. Zabezpieczyli także około 20 tys. zł w gotówce ${ }^{66}$.

W dokumentach Straży Granicznej rozróżnia się dwa rodzaje przemytu:

1) kryminalny, m.in. takich towarów akcyzowych, jak narkotyki, broń, materiały wybuchowe, substancje radioaktywne i chemiczne oraz samochody;

2) pospolity, takich towarów, jak papierosy, alkohol, produkty spożywcze ${ }^{67}$.

Według danych SG wykrywalność przemytu waha się w granicach 30-40\%. Największe straty z tego tytułu Skarb Państwa w wysokości około 30 bln starych zł poniósł w latach 1993-

65 Cudzoziemki próbowaty wytudzić kredyt, http://www/policja.pl/pol/ aktualnosci/31572.Cudzoziemki-probowaly-wyludzic-kredyt.html [dostęp: 6.11.2008].

66 Krakowscy policjanci zatrzymali 2 obywateli Chin pod zarzutem skimmingu, http://www.policja.pl/pol/aktualnosci/153381.Krakowscy-policjanci-zatrzymali-2-obywateli-Chin-pod-zarzutem-skimmingu.html [dostęp: 9.01.2018].

67 J.R. Truchan, Jednostki..., op.cit., s. 50. 
-1994. Najwięcej, bo 10 bln zł przyniósł przemyt papierosów, przemyt sprzęty elektronicznego - 8 bln zł, paliw $50 \mathrm{mln}$ zł. Według szacunków do Polski przemycanych jest około $30 \mathrm{mln}$ litrów alkoholu ${ }^{68}$.

Geograficznie Polska leży na szlaku przemytu narkotyków z Azji do Europy ${ }^{69}$. Już przed wojną w Polsce pojawiali się Chińczycy handlujący narkotykami. Dość swobodne normy prawne dotyczące produkcji i handlu narkotykami powoduje wzrost zainteresowania polskich grup przestępczych sprowadzaniem z tego kraju narkotyków i prekursorów do ich wyrobu. Do najbardziej spektakularnych sukcesów CBŚP i innych polskich służb należy przejęcie 1,2 t. GBL, nazywanej potocznie pigułką gwałtu, przesyłanej z Chin na Litwę, a dalej poprzez firmy kurierskie do Polski i innych krajów europejskich, Ameryki Północnej i Azji. Według szacunków wykryta wówczas grupa przestępcza mogła przesłać 335 t. narkotyków o czarnorynkowej wartości $21 \mathrm{mln}$ euro. Zaangażowani w ten proceder dwaj Polacy nie mieli kryminalnej przeszłości, a na Litwie sprzedawali środki czyszczące. Dopiero po wykryciu tej sprawy władze litewskie zdelegalizowały posiadanie GBL. W 2018 r. we współpracy z DEA CBŚP przejęło przesyłkę 3101 płynnego prekursora amfetaminy o wartości 1,2 mln zł. Narkotyki z Dalekiego Wschodu są przemycane m.in. w poszukiwanych w Europie Zachodniej ręcznie tkanych, pięknych, drogich dywanach. Wszywane są w postaci małych, o średnicy do $2 \mathrm{~mm}$ plastykowych rurkach $^{70}$.

W marcu 2019 r. policjanci z KMP w Lublinie, zajmujący się zwalczaniem przestępczością narkotykowej, zatrzymali wspólnie z funkcjonariuszami KAS 28-letni Chinkę, która była

\footnotetext{
68 Ibidem, s. 56-57.

69 Ibidem, s. 44.

70 J. R. Truchan, Jednostki..., op.cit., s. 55-56.
} 
odbiorcą przesyłki zawierającej prawie tysiąc tabletek zawierających nowe substancje psychoaktywne. Chinka została tymczasowo aresztowana na trzy miesiące ${ }^{71}$.

W 2010 r. w Toruniu CBŚ wykryło zorganizowaną grupę Wietnamczyków, którzy na produkcję marihuany najmowali domy na uboczu. W Toruniu wynajęli w tym celu dom na ul. Matysiaków w Czerniewicach, wyburzyli ściany, zasłonili okna i zainstalowali uprawę marihuany na skalę przemysłową przy pomocy instalacji nawadniającej, wentylacji z węglowymi filtrami powietrza i nagrzewnicami z 600-watowymi lampami. Dawało to tropikalny klimat, przy temperaturze 45 stopni i 80\% wilgotności. Jedna linia produkcyjna kosztowała około 300 tys. złotych. W oknach były specjalne kotary z oświetleniem włączanym wieczorem, aby z zewnątrz dom przypominał zamieszkały przez ludzi. Marihuanę uprawiali w Toruniu od lutego 2010 r., a w Bydgoszczy od listopada 2011 r. do czerwca 2010 r. zatrzymano 7 osób. W kraju wraz z Nadwiślańskim Oddziałem Straży Granicznej zlikwidowano kilkanaście takich upraw. Dom w Toruniu wynajęli na podstawie cudzych dokumentów. W Toruniu wyprodukowali $56,4 \mathrm{~kg}$ marihuany o wartości prawie 1,7 mln zł. Siedmiu oskarżonych 23 listopada 2012 r. Sąd Okręgowy w Toruniu skazał na kary od 3 do 4 lat pozbawienia wolności oraz grzywny od 1,5 do 3 tys. zł. Trzech musi także zapłacić 106 tys. zł właścicielom domu przy ul. Matysiaków. Zdewastowali także dom przy ul. Platynowej w Bydgoszczy ${ }^{72}$. W lipcu 2018 r. na statku, który zawinął do Gdyni, dzięki informacjom policji holenderskiej, ujawniono 3 t. haszyszu o czar-

71 Lublin: chińskie tabletki psychoaktywne, http://policja.pl/pol/aktualnosci/170953.Lublin-Chinskie-tabletki-psychoaktywne.html [dostęp: 15.03.2019].

72 KD, Proces Azjatów. Nie za zioła i klimat, "Gazeta Wyborcza”, 12.07.2011, s. 3; W. Piórkowski, Wietnamskie plantacje, „Nowości”, 24.11.2012, s. 3; Dostali popalić, „Gazeta Wyborcza”, 24.11.2012, s. 47. 
norynkowej wartości $60 \mathrm{mln}$ zł ukrytego w kartonach z pościelą. W tej sprawie CBŚP współpracowało z DEA i pakistańską Pakistan Antinarcotics Force.

Rano 5 sierpnia 2019 r. policja zatrzymała w okolicy centrum handlowego M1 w Krakowie 21 przybyszy z Kaukazu, którzy przyjechali luksusowymi autami. Wśród zatrzymanych jest kilku Polaków. W ten sposób policjanci zapobiegli konfrontacji z miejscowymi pseudokibicami. W działaniach brało udział kilkanaście radiowozów. Zabezpieczono broń palną, noże i maczety. Według relacji prasowych miała być planowana ustawka, lub walka o wpływy w handlu m.in. papierosami. Dziennikarze zwrócili uwagę na nielegalny handel papierosami na placach targowych w Krakowie i okolicy prowadzony przez Ormian i Czeczenów. Kibole Wisły z nimi współpracowali, ale stracili, gdy Misiek poszedł na współpracę z Policją ${ }^{73}$.

Ze względu na wysoki poziom zorganizowania oraz barierę językową bardzo trudne do zwalczania są triady chińskie. Istnieje podejrzenie, że zaangażowane są m.in. w nielegalny handel robotnikami budowlanymi ${ }^{74}$. W styczniu 2009 r. ujawniono zatrzymanie Chińczyka i Polaka podejrzanych o udział w przemycie przez nasz kraj osiemnastu Chińczyków do USA. Sprowadził ich Chińczyk pod pretekstem pracy w restauracji. Od każdego brali 10 tys. dolarów ${ }^{75}$. W sierpniu 2009 r. polska prasa donosiła o pożarze w Europejsko-Azjatyckim Centrum Handlowym w Wólce Kosowskiej. Przy okazji, powołując się na oficerów Biura Wywiadu Kryminalnego i CBŚ KGP, wskazywano, że działające tam triady były osłaniane przez oficerów chińskich służb

73 Obława na kiboli, „Gazeta Wyborcza”, 6.08.2019; B. Dybala, Policja zapobiegła bitwie pseudokibiców z obywatelami Rosji, „Nowości”, 6.08.2019.

74 M. Górnikiewicz, Przestępczość graniczna jako jedna z form aktywności chińskich grup przestępczych, [w:] Bezpieczeństwo granic Rzeczypospolitej Polskiej, red. A. Konpka, G. Sobolewski, Białystok 2011, s. 332.

75 Ibidem, s. 335. 
specjalnych. Wskazywano na rosnącą diasporę chińską w Polsce i rozwoju współpracy naukowej i jednoczesnym nadzorem nad tym chińskich służb specjalnych. Wskazywano, że triadom w Polsce zabroniono ze względów strategicznych prowadzenia działalności wywołującej poczucie zagrożenia ludności polskiej, takich jak handel ludźmi, zabójstwa, rozboje, kradzieże, pobieranie haraczy, czerpanie korzyści z nierządu. Polska miała być bazą wypadową do Europy. Miały triady poszerzać kontakty z osobami mającymi dostęp do informacji. W 2009 r. zamordowany został domniemany szef triad w Polsce ${ }^{76}$.

Kolejnym problemem jest nielegalne zatrudnienie. W ostatnim tygodniu 2019 r. funkcjonariusze Morskiego Oddziały SG w czasie kontroli ujawnili trzynastu cudzoziemców nielegalnie pracujących i bez zezwolenia przebywających w Polsce. Wśród nich był Serb ${ }^{77}$. W marcu 2019 r. policjanci z woj. dolnośląskiego zatrzymali dwóch mężczyzn zajmujących się pośrednictwem pracy i podejrzanych o nielegalne sprowadzenie do pracy w Polsce 76 Filipińczyków. Cudzoziemcy ci nie mieli paszportów i według policjantów przed przyjazdem do Polski byli wprowadzeni w błąd w sprawie m.in. wysokości zarobków ${ }^{78}$.

Początkowo we współpracy polsko-niemieckiej w zwalczaniu przestępstw popełnianych przez Azjatów nie brakowało potknięć, np. policja polska i brandenburska prowadziły postępowanie w tej samej sprawie. W pewnej sprawie zamierzano w Polsce i RFN postawić zarzuty Pakistańczykowi ściganemu międzynarodowym listem gończym, ale Polscy postawili mu zarzut

76 L. Szymowski, Chińska mafia wkracza do Polski, „Polska The Times”, 27.08.2009.

77 Znowu nielegalni, „Gazeta Kołobrzeska”, 3.01.2020, nr 1, s. 3.

78 Sprowadzali do pracy w Polsce 76 obywateli Filipin. Odpowiedza za handel ludźmi, http://policja.pl/pol/aktualnosci/171502.sprowadzali-do-pracy-w-Polsce-76-obywateli-Filipin-Odpowiedza-za-handel-ludzmi.html [dostęp: 27.03.2019]. 
za złamanie przepisów ruchu drogowego i zwolniony, po czym trafił do aresztu deportacyjnego ${ }^{79}$.

Sprawy zatrzymanych w Polsce Azjatów trafiają także do Europejskiego Trybunału Sprawiedliwości. W maju 2019 r. w sprawie Liu przeciwko Polsce (skarga nr 37610/18) ETS zapytał polski rząd czy ekstradycja tego Tajwańczyka oskarżonego o udział w syndykacie zajmującym się oszustwami telekomunikacyjnymi do Chin, nie narazi go na niebezpieczeństwo tortur i nieludzkiego traktowania. Zapytano także czy areszt trwający rok i siedem miesięcy nie jest zbyt długi. Trybunał nakazał wstrzymanie się z ekstradycją Liu ${ }^{80}$.

Azjaci bywali także ofiarami przestępstw. W 2008 r. mysłowiccy policjanci zatrzymali dwóch Bułgarów usiłujących wymusić haracz od Pakistańczyków handlującym na miejscowym targowisku. Po odmowie zapłacenia go, jeden z Bułgarów strzelił do Pakistańczyków z pistoletu-wiatrówki i doszło do bójki. Śrutem ranna została kobieta, która przypadkowo tam przechodzi$\mathrm{ła}^{81}$.

Ujawniano także Azjatów nielegalnie pracujących w Polsce. Na przykład w 2007 r. 17 Malezyjczyków, 16 Wietnamczyków, 15 Koreańczyków z KRLD, 15 Hindusów, 11 Chińczyków i 7 Japończyków. W 2008 r. 42 Wietnamczyków, 33 Chińczyków, 10 Turków, 6 Ormian, 4 Uzbeków i Hindusa. W 2009 r. 58 Chińczyków, 34 Hindusów, 29 Filipińczyków, 21 Tajlandczyków, 17 Turków, 15 Nepalczyków, 9 Ormian, 6 obywateli Korei Południowej, 5 Bengalczyków, 2 Uzbeków. W 2009 r.

79 R. Leppin, Głos w dyskusji, [w:] Przestępczość przygraniczna, t. 1: Relacje praktyków, red. A.J. Szwarc, G. Wolf, Frankfurt n/Odrą-SłubicePoznań 2001, s. 188-189.

80 M. Mrowiński, Policja musi miarkować się, „Rzeczpospolita”, 2.07.2019, s. D1.

81 Bułgarzy strzelali do Pakistańczyków, http://www.policja.pl/pol/ aktualnosci.31394.Bulgarzu-strzeleli-do-Pakistanczykow.html [dostęp: 3.11.2008]. 
77 Chińczyków, 64 Filipińczyków, 30 obywateli KRLD, 27 Uzbeków, 21 Nepalczyków, 19 Bengalczyków, 13 Ormian, 9 Turków, 7 Tajlandczyków, 6 obywateli Południowej Korei i 4 Hindusów. W 2011 r. ujawniono 59 Chińczyków, 28 obywateli Korei Południowej, 18 Turków, 5 Nepalczyków, 4 Tajlandczyków, 3 Ormian, 2 Hindusów, 1 obywatela KRLD, 1 Uzbeka, 1 Bengalczyka. W 2012 r. 34 Chińczyków, 25 obywateli Republiki Południowej Korei, 8 obywateli KRLD, 7 Hindusów, 5 Turków, 4 Filipińczyków, 3 Uzbeków, 1 Nepalczyków, 1 Bengalczyka, 1 Ormianina. W 2013 r. 16 Chińczyków, 7 Hindusów, 6 Turków, 5 Ormian, 3 Nepalczyków, 3 Tajlandczyków, 1 obywatela KRLD, 1 Uzbeka i 1 Bengalczyka. Miały tylko miejsce nieujawniane przypadki czynów popełnionych na szkodę swoich rodaków. Prawdopodobnie najwięcej ich popełniali Wietnamczycy i Czeczeni. Do tej grupy należy zaliczyć przestępstwa popełniane na szkodę kobiet uchodzących w niektórych kulturach, np. czeczeńskiej, za własność swoim mężów. Nie można tu pomijać zgwałconych kobiet, jakby były sprawcami. Znany jest też przykład wywiezienia z Polski Czeczenki, aby dokonać w kraju rodzimym zabójstwa honorowego ${ }^{82}$.

W latach 2004-2014 najwięcej przewidzianych w Kodeksie karnym przestępstw Azjaci popełnili w woj. podkarpackim, podlaskim i kujawsko-pomorskim - ponad $90 \%{ }^{83}$.

Źródła wskazują, że od lat Azjaci w Polsce są także ofiarami przestępstw. Jest to temat na odrębne opracowanie. Tu tylko dla ilustracji wskazanych zostanie kilka przykładów. W listopadzie 2008 r. mysłowiccy policjanci zatrzymali na miejskim targowisku dwóch Bułgarów pod zarzutem usiłowania wymuszenia haraczu od handlujących tam Pakistańczyków. Jeden z pokrzywdzonych został postrzelony z wiatrówki. Przy okazji

\footnotetext{
82 D. Woźniakowska-Fajst, Cudzoziemcy..., op.cit., s. 51.

83 I. Rzeplińska, J. Włodarczyk-Madejska, Przestępczość..., op.cit., s. 30.
} 
funkcjonariusze w samochodach pokrzywdzonych znaleziono podróbki odzieży znanych firm ${ }^{84}$. Policjanci z Boguszowic w pow. rybnickim zatrzymali 25-letniego mężczyznę podejrzanego o dokonaniu napadu na obywateli Indii. Napastnik miał się domagać od nich pieniędzy. Przy okazji ustalono, że podejrzany w stanie nietrzeźwym jechał skradzionym skuterem ${ }^{85}$.

Na koniec warto wspomnieć o współpracy policyjnej z państwami azjatyckimi. W grudniu 2017 r. nadkom. Piotr Janik - dyrektor Biura Kryminalnego KGP, mł. insp. Piotr Nepelski - dyrektor Instytutu Badań i Rozwoju Wyższej Szkoły Policji w Szczytnie oraz podinsp.. Dariusz Skowronek - radca Biura Międzynarodowej Współpracy Policji KGP na zaproszenie Ministerstwa Bezpieczeństwa Publicznego Chińskiej Republiki Ludowej uczestniczyli w Trzecim Międzynarodowym Forum Współpracy Organów Ścigania na temat Bezpieczeństwa Korytarza Nowego Euroazjatyckiego Mostu Lądowego. Współpraca w tym zakresie została zainicjowana w 2015 r. i była kontynuowana w 2016 r. wzrosła też liczba uczestników z 14 do 34, W tym delegacja Interpolu. Wypracowano nowe dwustronne i wielostronne rozwiązania: „Pięć wspólnych wizji”, „Pięć planów działań”. Forum służy też budowaniu zaufania. Mariusz Nepalski uczestniczył w think tanku poświęconym współpracy szkolnictwa policyjnego i platformy współpracy „Stowarzyszenie Akademii Policyjnych Forum Lianyungang"86.

84 Butgarzy strzelali do Pakistańczyków, http://www.policja.pl/pol/ aktualnosci/31394.Bulgarzy-strzelali-do-Pakistanczykow.html [dostęp: 3.11.2008].

85 Nie pomogła znajomość języka, http://policja.pl/pol/aktualnosci171384.Nie-pomogla-znajomosc-jezyka.html [dostęp: 25.03.2019].

86 Wizyta przedstawicieli polskiej policji w Chinach, http://www.policja. pl/pol/aktualnosci/152768.Wizyta-przedstawicieli-polskiej-Policji-w-Chinach.html [dostęp: 19.12.2017]. 


\section{Bibliografia}

Akcja CBŚP i SG. Rozbity gang ułatwiajacy nielegalny pobyt cudzoziemcom w Polsce, http://policja.pl/pol/aktualnosci/170456.Akcja-CBSP-i-SG-Rozbity-gang-ulatwiajacynielegalny-pobyt-cudzoziemcom-w-Polsce.html.

Brzozowski S., Krwawe curry, „Reporter” 2019, nr 12.

Bułgarzy strzelali do Pakistańczyków, http://www.policja.pl/ pol/aktualnosci.31394.Bulgarzu-strzeleli-do-Pakistanczykow.html.

Cudzoziemki próbowaty wytudzić kredyt, http://www/policja. $\mathrm{pl} / \mathrm{pol} /$ aktualnosci/31572.Cudzoziemki-probowaly-wyludzic-kredyt.html.

Deszczyński P., Migracje zewnętrzne a bezpieczeństwo gospodarcze państw, [w:] Bezpieczeństwo państwa a procesy migracyjne, red. L. Kacprzak, J. Knopek, Piła 2008.

Dostali popalić, „Gazeta Wyborcza”, 24.11.2012.

Dybala B., Policja zapobiegła bitwie pseudokibiców z obywatelami Rosji, „Nowości”, 6.08.2019.

Good morning. Vietnam 10, „Angora”, 30.09.2018, nr 39.

Górnikiewicz M., Przestępczość graniczna jako jedna z form aktywności chińskich grup przestępczych, [w:] Bezpieczeństwo granic Rzeczypospolitej Polskiej, red. A. Konpka, G. Sobolewski, Białystok 2011.

Hoc S., Przestępczość cudzoziemców ze szczególnym uwzględnieniem Warszawy i województw mazowieckiego, [w:] Przestępczość i zjawiska patologiczne w województwie mazowieckim, red. F. Prusak, Warszawa 2003.

Kaleta E., Nie mówcie do nas: Jesteś brudnym śmieciem, „Duży Format", 16.01.2017.

Kamiński M., Przestępczość przygraniczna w rejonie środkowego odcinka polskiej granicy zachodniej, [w:] Przestępczość 
przygraniczna, t. 1: Relacje praktyków, red. A.J. Szwarc, G. Wolf, Frankfurt n/Odrą-Słubice-Poznań 2001.

KD, Proces Azjatów. Nie za zioła i klimat, „Gazeta Wyborcza Toruń" z 12 lipca 2011 r.

Krakowscy policjanci zatrzymali 2 obywateli Chin pod zarzutem skimmingu, http://www.policja.pl/pol/aktualnosci/153381. Krakowscy-policjanci-zatrzymali-2-obywateli-Chin-pod-zarzutem-skimmingu.html.

Księżopolski K.M., Wpływ migracji na bezpieczeństwo ekonomiczne państwa, [w:] Bezpieczeństwo państwa a procesy migracyjne, red. L. Kacprzak, J. Knopek, Piła 2008.

Leppin R., Głos w dyskusji, [w:] Przestepczość przygraniczna, t. 1: Relacje praktyków, red. A.J. Szwarc, G. Wolf, Frankfurt n/Odrą-Słubice-Poznań 2001.

Lubiewski P., Wptyw nielegalnej imigracji na bezpieczeństwo wewnętrzne Rzeczypospolitej Polskiej, [w:] Meandry bezpieczeństwa wewnętrznego państwa, red. A. Babiński, Szczytno 2017.

Lublin: chińskie tabletki psychoaktywne, http://policja.pl/pol/ aktualnosci/170953.Lublin-Chinskie-tabletki-psychoaktywne.html.

Nielegalni imigranci w ciężarówce z kartonami, http://www. policja.pl/pol/aktualnosci/166251.Nielegalni-imigranci-w-ciezarowce-z-kartonami.html.

Nie pomogła znajomość języka, http://policja.pl/pol/aktualnosci171384.Nie-pomogla-znajomosc-jezyka.html.

Obława na kiboli, „Gazeta Wyborcza”, 6.08.2019.

Perkowska M., Dynamika i struktura przestępczości granicznej cudzoziemców w Polsce na podstawie danych statystycznych Komendy Głównej Straży Granicznej, [w:] Przestępczość cudzoziemców: aspekty prawne, kryminologiczne i praktyczne, red. W. Klaus, K. Laskowska, I. Rzeplińska, Warszawa 2017. Perkowska M., Przestępczość graniczna w ujęciu fenomenolo- 
gicznym, [w:] Bezpieczeństw granic Rzeczypospolitej Polskiej, red. A. Konopka, G. Sobolewski, Białystok 2011.

Piechowiak G., Przestępczość na emigracji na przyktadzie polskiej emigracji zarobkowej we Wtoszech w latach 90. XX wieku, [w:] Bezpieczeństwo państwa a procesy migracyjne, red. L. Kacprzak, J. Knopek, Piła 2008.

Pieszo i autostopem przemierzyli 9 państw - policjanci zatrzymali dwóch nastolatków z Afganistanu, http://www.policja. $\mathrm{pl} /$ pol/aktualnosci/153393.Pieszo-i-autostopem-przemierzyli-9-panstw-policjanci-zatrzymali-dwoch-nastolatko.html.

Pietras-Eichberger M., Wybrane aspekty bezpieczeństwa granicy polsko-ukraińskiej, [w:] Bezpieczeństwo granic Rzeczpospolitej Polskiej, red., A. Konopka, G. Sobolewski, Białystok 2011.

Piórkowski W., Wietnamskie plantacje, „Nowości”, 24.11.2012. Pływaczewski W., Relacje pomiędzy zjawiskiem nielegalnej imigracji a przestępczościa oraz innymi przejawami zachowań patologicznych w różnych ich postaciach, [w:] Polska w Schengen, red. M. Zdanowicz, Białystok 2009.

Pokruszyński W., Uwarunkowanie wspótczesnego bezpieczeństwa międzynarodowego, Szczytno 2006.

Rzeplińska I., Włodarczyk-Madejska J., Przestępczość cudzoziemców w Polsce - na podstawie policyjnych statystyk przestępczości, [w:] Przestępczość cudzoziemców. Aspekty prawne, kryminologiczne i praktyczne, red. W. Klaus, K. Laskowska, I. Rzeplińska, Warszawa 2017.

Sprengel B., Migracja z Polski a przestępczość, [w:] Społeczna przestrzeń Polaków żyjacych $w$ diasporze, red. M. Sprengel, Poznań 2008.

Sprengel B., Policja a migracja, [w:] Bezpieczeństwo państwa a procesy migracyjne, red. L. Kacprzak, J. Knopek, Piła 2008.

Sprengel B., Polsko-niemieckie stosunki stużb policyjnych w okre- 
sie międzywojennym, [w:] Spotkania polsko-niemieckie, red. D. Kawa, Toruń 2011.

Sprowadzali do pracy $w$ Polsce 76 obywateli Filipin. Odpowiedza za handel ludźmi, http://policja.pl/pol/aktualnosci/171502.sprowadzali-do-pracy-w-Polsce-76-obywateliFilipin-Odpowiedza-za-handel-ludzmi.html.

Stawnicka J., Dyskurs o bezpieczeństwie z perspektywy lingwosecuritologii, Katowice 2016.

Szudrowicz J., Struktury, rozmiary i zwalczanie przestępczości granicznej i przygranicznej w okręgu dziatania prokuratury Rejonowej w Stubicach w latach 1990-1995, [w:] Przestępczość przygraniczna, t. 1: Reakcje praktyków, red. A.J. Szwarc, G. Wolf, Frankfurt n/Odrą-Słubice-Poznań 2001.

Szymanowski L., Chińska mafia wkracza do Polski, „Polska The Times", 27.08.2009.

Szymanowski L., To nie kibice, to bandyci, „Angora”, 17.12.2017, nr 51.

Truchan J.R., Jednostki specjalne Policji i Straży Granicznej w ochronie wschodniej granicy Polski, Szczytno 2014.

Wiśniewski B., Podleś D., Zagrożenia bezpieczeństwa publicznego, „Biuletyn Centrum Szkolenia Straży Granicznej” 2004, nr 28.

Wizyta przedstawicieli polskiej policji w Chinach, http://www. policja.pl/pol/aktualnosci/152768.Wizyta-przedstawicieli-polskiej-Policji-w-Chinach.html.

Woźniakowska-Fajst D., Cudzoziemcy jako sprawcy przestępstw przeciwko życiu i zdrowiu, [w:] Przestępczość cudzoziemców. Aspektu prawne, kryminologiczne i praktyczne, Warszawa 2017.

Zając J., Bezpieczeństwo państwa, [w:] Bezpieczeństwa państwa. Wybrane problemy, red. K.A. Wojtaszczyk, A. Materska-Sosnowska, Warszawa 2009.

Znowu nielegalni, „Gazeta Kołobrzeska”, 3.01.2020, nr 1. 


\begin{abstract}
Abstrakt
Jedną z konsekwencji zmian przemian ustrojowych w Polsce było otwarcie granicy. Spowodowało to migrację do Polski i przez Polskę dużej ilości Azjatów. Wśród migrantów nie brakowało przestępców. Pojawił się na dużą przemyt ludzi, kradzionych samochodów, wyrobów tytoniowych i alkoholu. Także przybywający do Polski członkowie zorganizowanych grup przestępczych podejmowali na terenie kraju nielegalną działalność. Także niektórzy inni Azjaci osiedlający się w Polsce popełniają przestępstwa, ale także są ich ofiarami.
\end{abstract}

Słowa kluczowe: Azjaci, przemyt, przestępczość, przestępczość Azjatów

\begin{abstract}
One of consequence transformation political system in Poland was open the border. In the consequence many Asian next was migration to Poland and across Poland. Among migrations was criminal. Was a problem smuligg people, robbery cars, tobacco and alcohol. Was activity in Poland members of gangs from Asia. Stay in Poland Asian was the crime victim.
\end{abstract}

Keywords: Asian, smuggling, crime, Asian crime 


\author{
Jerzy Szukalski \\ Wyższa Szkola Stosunków Międzynarodowych i Komunikacji \\ Społecznej w Chełmie \\ ORCID ID: https://orcid.org/0000-0001-9960-7571
}

\title{
Sądownictwo polubowne w państwach Azji Centralnej
}

\section{Wprowadzenie}

Polubowne załatwianie sporów i sądownictwo polubowne cieszą się w państwach Azji Centralnej dużym uznaniem i popularnością, co wynika z określonych uwarunkowań politycznych, mentalnych i religijnych. Należy przede wszystkim wskazać w tym względzie na to, że państwa tego regionu, do których zaliczamy: Kazachstan, Uzbekistan, Turkmenistan, Kirgistan i Tadżykistan przez długi okres pozbawione były suwerennego bytu państwowego. W drugiej połowie XIX w. terytoria tych państw w wyniku rosyjskiego podboju znalazły się bowiem w składzie Imperium Rosyjskiego jako jego generałgubernatorstwo turkiestańskie, a po I wojnie światowej i upadku caratu zostały one opanowane przez bolszewików i wcielone do Związku Radzieckiego jako republiki związkowe. Dopiero w wyniku „pierestrojki”, zainicjowanej w 1985 r. przez ówczesnego radzieckiego przywódcę partyjnego i państwowego Michaiła Gorbaczowa, a później rozpadu Związku Radzieckiego w latach 1989-1991, jego azjatyckie republiki związkowe uzyskały niepodległy byt państwowy w 1991 r. $^{1}$

1 Н.С. Киняпина, Центральная Азия во внутренней политике России во второй половине XIX века, [в:] История России XIX - начала XX 
Spuścizna radziecka pozostawiła po sobie w nowych państwach Azji Centralnej brak społeczeństwa obywatelskiego, niski poziom kultury prawnej oraz ograniczone zaufanie do instytucji państwowych, zwłaszcza wśród ludności wiejskiej, przywiązanej do tradycji i islamu. W warunkach państwa totalitarnego, jakim był Związek Radziecki, łamane były bowiem podstawowe prawa i wolności jednostki, a ich instytucjonalna ochrona była znikoma. Sądownictwo wszystkich szczebli i prokuratura były tam dyspozycyjne wobec władz partyjno-państwowych. Po uzyskaniu niepodległości przez państwa Azji Centralnej sytuacja w obszarze ochrony praw jednostki niewiele się zmieniła, chociaż formalnie przyjęły one demokratyczny porządek prawny, czego wyrazem są ich konstytucje i ustawodawstwo - na ogół zgodne z przyjętymi przez te państwa zobowiązaniami międzynarodowymi. W praktyce jednak w każdym z państw regionu, za wyjątkiem Kirgistanu, wykształcił się reżim autorytarny, w którym ochrona praw i wolności człowieka nie stanowi priorytetu dla władz państwowych ${ }^{2}$. Sądownictwo pozostaje tam w dużej mierze dyspozycyjne wobec władzy wykonawczej, a ponadto trawi go korupcja. Stąd mieszkańcy państw Azji Centralnej, zarówno w okresie radzieckim, jak i już w warunkach państw niepodległych, darzą raczej nieufnością sądy państwowe, preferując alternatywne formy rozstrzygania sporów ${ }^{3}$.

века, реА. В.А. Федоров, Москва 2004, s. 486-513; F.S. Massansalvador, The Process of Nation Building in Central Asia and its Relationship to Russia's Regional Influence, Miami 2010, s. 3-12, http://aei.pitt.edu/29783/1/ SerraNationbldgCentAsiaLongJune10.pdf [dostęp: 10.08.2019].

2 T. Bodio, T. Mołdawa, Konstytucje państw Azji Centralnej: tradycje i wspótczesność, Warszawa 2007, s. 15-16; Н. Борисов, Институт президентства в странах Центральной Азии: персонализаиия vs. институционализация, „Центрамьная Азия и Кавказ” 2011, t. 14, s. 65-75, https://cyberleninka.ru/article/n/institut-prezidentstva-v-stranah-tsentralnoy-azii-personalizatsiya-vs-institutsionalizatsiya [dostęp: 10.05.2019].

3 Б. Асанов, Верховный суд не согласен с мнением, что граждане не доверяют системе, https://rus.azattyk.org/a/kyrgyzstan_court_rating/29501608.html [dostęp: 25.07.2019]. 
Dość niski stopień zaufania do sądów państwowych i wybór sądów polubownych wynika również z endemicznych uwarunkowań, charakterystycznych dla państw Azji Centralnej. Stanowi je plemienno-klanowa struktura tamtejszego społeczeństwa i związane z tym funkcjonowanie układów trybalnych. W państwach tego regionu ciągle bardzo dużą rolę odgrywają wspólnoty rodowo-plemienne i klanowo-terytorialne, które łączy genealogia, solidarność subetniczna i regionalno-plemienna oraz patronacka zależność ich członków od elit klanowych. $\mathrm{O}$ awansie do elit władzy, zdobyciu stanowisk w administracji rządowej czy samorządowej decydują przede wszystkim: przynależność do rodu, plemienia i klanu, zajmowana pozycja w strukturach tych wspólnot oraz lojalność i posłuszeństwo wobec przywódców. Natomiast kompetencje i wykształcenie mają w tym względzie o wiele mniejsze znaczenie. Z trybalizmem związane są nieodłącznie: klientelizm, korupcja, nepotyzm, relacje patronalno-klientalne i kultura poddańcza ${ }^{4}$. W społeczeństwie, w którym funkcjonują układy trybalne wiele spraw - w zależności od ich wagi - jest załatwianych na poziomie klanu, rodu bądź rodziny lub przed sądami polubownymi, bez potrzeby uciekania się do sądów państwowych ${ }^{5}$.

Innymi czynnikami sprzyjającymi rozwojowi sądownictwa polubownego w państwach Azji Centralnej są odradzający się po czasach radzieckich represji islam i adat, czyli prawo zwy-

4 Szerzej zob. T. Bodio, Uktady klanowe jako mechanizm polityki (na przykładzie państw Azji Centralnej), [w:] Transformacja społeczeństwa $i$ wtadzy w postradzieckiej Azji Centralnej: studia i rozprawy, red. T. Bodio, W. Jakubowski, A. Wierzbicki, Pułtusk 2008, s. 152-162; A. Wierzbicki, P. Załęski, Trybalizm a władza w Azji Centralnej, Pułtusk 2008, s. 282-288; P. Załęski, Kultura polityczna więzi w Azji Centralnej (przypadek Kirgistanu na tle państw regionu), Warszawa 2011, s. 45-48, 117-129, 269-301.

5 А. Грозин, Элиты Туркменистана и центральноазиатские клань: общее, особенное и трудности модернизации, http://www.perspektivy.info/table/elity_turkmenistana_i_centralnoaziatskije_klany_obshheje_ osobennoje_i_trudnosti_modernizacii_2010-12-21.htm [dostęp: 11.05.2019]. 
czajowe. Przed rosyjskim podbojem na obszarach Azji Centralnej funkcjonowało wśród autochtonów przede wszystkim sądownictwo szariackie, a także sądy bijów i sądy aksakałów, które zostały ostatecznie zlikwidowane przez władze radzieckie. W niepodległych państwach regionu, pomimo przyjętej w nich formuły państwa świeckiego jako jednej z naczelnych zasad konstytucyjnych, można zaobserwować tendencje do restytucji sądownictwa szariackiego, wspierane szczególnie przez radykalne odłamy islamu ${ }^{6}$. Zdarza się nawet, że w niektórych obszarach wiejskich Kazachstanu, Kirgistanu i Tadżykistanu, a zwłaszcza w jego wysokogórskiej części - Badachszanie, funkcjonują przy meczetach nieformalne szariackie sądy polubowne, chociaż są one zwalczane przez władze państwowe ${ }^{7}$.

Celem opracowania jest prezentacja sądów polubownych w państwach Azji Centralnej w wymiarze normatywnym. Z uwagi na ograniczone ramy objętościowe uwzględniono w nim wyłącznie oficjalne sądy polubowne, które funkcjonują w oparciu o przepisy obowiązujących aktów prawnych.

\section{Podstawy prawne}

Spośród państw Azji Centralnej sądy polubowne funkcjonują obecnie w Uzbekistanie, Kirgistanie i Tadżykistanie. W Kazachstanie i Turkmenistanie ustawodawstwo przewiduje wprawdzie

6 Szerzej zob. P. Jones, Islam, Society, and Politics in Central Asia, Pittsburgh 2017, s. 13-78; A. Wolters, The State and Islam in Central Asia: Administering the Religious Threat or Engaging Muslim Communities?, Göttingen 2014, s. 4-21, https://www.econstor.eu/handle/10419/102032 [dostęp: 24.07.2019]; В.В. Корнеев, Шариатские судь в Туркестане, http://www. ng.ru/ng_religii/2001-02-14/8_court.html [dostęp: 24.07.2019]; А.В. Аогинов, Адат и иариат в регионах Кавказа и Центральной Азии в постсоветский период, „Современный мусумьманский мир” 2018, nr 3, s. 2, https:// islamjournal.ru/2018/id41/ [dostęp: 24.07.2019].

7 С. Мустафин, Современная «инквизиция» или линчевание по Памирски?, http://www.ca-portal.ru/article:35012 [dostęp: 24.07.2019]. 
możliwość polubownego załatwiania części sporów z zakresu prawa cywilnego, pracy, rodzinnego i karnego przed sądami państwowymi, lecz bez możliwości tworzenia odrębnych sądów polubownych $^{8}$. W przypadku Kazachstanu kwestie te, poza Kodeksem cywilnym (art. 183) ${ }^{9}$, Kodeksem postępowania cywilnego (art. 25, 49, 53, 55, 56, 61, 79, 106, 113, 153, 170, 185, 192, 193, 240, 242, 247, 342 i 383) ${ }^{10}$, Kodeksem podatkowym (art. 42, 181 i 548) ${ }^{11}$, Kodeksem małżeńskim i rodzinnym (art. 18, 37, 73 i 183) ${ }^{12}$, Kodeksem karnym (art. 68, 251 i 421) ${ }^{13}$, Kodeksem postępowania karnego (art. 23, 85 i 170) ${ }^{14}$ oraz ustawą z dnia z dnia 23 stycznia 2001 r. o lokalnej władzy państwowej i samorządzie terytorialnym w Republice Kazachstanu ${ }^{15}$, uregulowano nawet

8 С.А. Тюльканов, К.В. Геворкова, Законодательные основы применения медиации в странах СНГ и ближнего зарубежья, s. 148-149, 153, http://lexandbusiness.ru/view-article.php?id=6917 [dostęp: 11.05.2019].

9 ГражАанский кодекс Республики Казахстан № 269-XII от 27 Аекабря 1994 года (по состоянию на 1 июця 2019 года), https://online.zakon. kz/document/?doc_id=1006061 [dostęp: 10.08.2019].

10 ГражАанский процессуальный кодекс Республики Казахстан № 377-V ЗРК от 31 октября 2015 года (по состоянию на 22 июля 2019 года), https://zakon.uchet.kz/rus/docs/K1500000377 [dostęp: 10.08.2019].

11 Pełna nazwa przywołanego kodeksu brzmi właściwie: Kodeks Republiki Kazachstanu o podatkach i innych budżetowych zobowiązaniach podatkowych (Kodeks podatkowy). Zob. Кодекс Республики Казахстан «О налогах и Аругих обязательных платежах в бюджет» (Налоговый кодекс) № 120VI ЗРК от 25 Аекабря 2017 года (по состоянию на 1 августа 2019 года), https://online.zakon.kz/document/?doc_id=36148637\#pos=5;-34 [dostęp: 10.08.2019].

12 Кодекс Республики Казахстан «О браке (супружестве) и семье» № 518-IV от 26 декабря 2011 года (по состоянию на 1 апрекя 2019 года), https://online.zakon.kz/document/?doc_id=31102748 [dostęp: 10.08.2019].

13 Уголовный кодекс Республики Казахстан № 226-V от 3 июля 2014 года (по состоянию на 1 августа 2019 года), https://online.zakon.kz/ document/?doc_id=31575252 [dostęp: 10.08.2019].

14 Уголовно-процессуальный кодекс Республики Казахстан № 231-V от 4 июля 2014 года (по состоянию на 1 апреля 2019 года), https://online. zakon.kz/document/?doc_id=31575852 [dostęp: 10.08.2019].

15 Закон Республики Казахстан № 148-II от 23 января 2001 года «О местном госуаарственном управлении и самоуправ ении в Респу- 
w odrębnej ustawie z dnia 28 stycznia 2011 r. o mediacji (art. 35), która umożliwia polubowne załatwianie sporów z udziałem niezależnych mediatorów w procedurze zbliżonej do sądów polubownych ${ }^{16}$. W Turkmenistanie zaś przepisy dotyczące polubownego załatwienia sporów są zawarte w Kodeksie pracy (art. 74 ust. 4 i art. 104) i Kodeksie rodzinnym (art. 64) ${ }^{17}$.

W Kirgistanie możliwość tworzenia sądów polubownych otrzymała umocowanie konstytucyjne. Konstytucja tego państwa w redakcji z 27 czerwca 2010 r. stanowi bowiem w przepisie art. 58, że „W przypadku pozasądowego rozstrzygania sporów wynikających ze spraw cywilnych można ustanowić sądy polubowne. Uprawnienia, procedurę tworzenia i działalności sądów polubownych określa ustawa"18. Konstytucja Kirgistanu przewiduje też w przepisie art. 59 możliwość powoływania sądów aksakałów, czyli sądów mędrców. Są one formą sądów polubownych, odwołujących się w nazewnictwie do kirgiskich tradycji. Sama nazwa „aksakał” oznacza „białą brodę”, która jest jednym z wyróżników mężczyzn w podeszłym wieku ${ }^{19}$. Przywo-

6цике Казахстан» (по состоянию на 3 апреля 2019 года), https://online. zakon.kz/document/?doc_id=1021546 [dostęp: 10.08.2019].

16 Закон Респубцики Казахстан № 401-IV от 28 января 2011 года «О медиации», https://online.zakon.kz/Document/?doc_id=30927 376\#pos=298;5 [dostęp: 12.05.2019].

17 Zob. Трудовой кодекс Туркменистана № 30-IV от 18 апреля 2009 года (по состоянию на 2 марта 2019 года), http://www.minjust.gov.tm/ru/ mmerkezi/doc_view.php?doc_id=8334 [dostęp: 12.05.2019]; Семейный коАекс Туркменистана от № 258-IV от 10 января 2012 гоАа (по состоянию на 1 декабря 2018 года), http://base.spinform.ru/show_doc.fwx?rgn=50609 [dostęp: 12.05.2019]; Тюльканов С.А., Геворкова К.В., ор.cit., s. 153.

18 Конституция Кыргызской Республики принята референдумом (всенародным голосованием) 27 июня 2010 года, (В редакции Закона Кыргызской Республики № 218 от 28 декабря 2016 года), http://cbd.minjust.gov.kg/act/view/ru-ru/202913?cl=ru-ru [dostęp: 12.05.2019].

19 А. Сумейменов, Аксакал: вчера, сегодня, завтра, https://e-history.kz/ ru/publications/view/2726 [dostęp: 12.05.2019]; А. Аинара, Роль судов аксакалов в местном сообществе Кыргызской Республики, https://www.academia. edu/18027456/Статья_Аля_конференции_в_H [dostęp: 12.05.2019]. 
łany przepis - podobnie jak w przypadku sądów polubownych zawiera odesłanie ustawowe. Należy jeszcze wskazać, że chociaż Konstytucja Kirgistanu dopuszcza możliwość tworzenia sądów polubownych i sądów aksakałów, to jednak ich funkcjonowanie nie koresponduje z przepisem art. 93 ust. 2 ustawy zasadniczej. Brakuje w nim bowiem wśród wszystkich nazw wymienionych sądów, składających się na system sądownictwa w tym państwie (nie tylko zresztą państwowego), sądów polubownych i sądów aksakałów, co wydaje się być rozwiązaniem niekonsekwentnym ze strony ustrojodawcy ${ }^{20}$.

Szczegółowe regulacje dotyczące sądów polubownych w Kirgistanie zawiera ustawa z dnia 30 lipca 2002 r. o sądach polubownych w Republice Kirgiskiej ${ }^{21}$. Z kolei powoływanie i działalność sądów aksakałów początkowo regulował tymczasowy regulamin o sądach aksakałów Republiki Kirgiskiej, zatwierdzony dekretem Prezydenta Republiki Kirgiskiej z dnia 25 stycznia 1995 r. $^{22}$, a następnie ustawa z dnia 5 lipca 2002 r. o sądach aksakałów ${ }^{23}$, chociaż pierwsze tego rodzaju sądy zostały utworzone w Kirgistanie już w 1993 r. ${ }^{24}$ Ponadto przepisy dotyczące możliwości rozstrzygania sporów cywilnych przed wdaniem się

20 J. Szukalski, System konstytucyjny Kirgistanu, Warszawa 2018, s. 122.

21 Закон Кыргызской Республики № 135 от 30 июля 2002 года «Об третейских судах в Кыргызской Республике» (по состоянию на 11 июня 2004 года), http://cbd.minjust.gov.kg/act/view/ky-kg/1092/10?cl=ky-kg [dostęp: 12.05.2019].

22 Zob. Временное положение «О судах аксакалов Кыргызской Республики», утверждено Указом Президента Кыргызской Республики № УП-30 от 25 января 1995 года (утратим сику в соответствии с Указом Президента КР № УП-139 от 7 июня 2013 года), http://cbd.minjust.gov. kg/act/view/ru-ru/46732 [dostęp: 13.05.2019].

23 Zob. Закон Кыргызской Республики № 113 от 5 июля 2002 года «О судах аксакацов» (по состоянию на 27 апреля 2017 года), http://cbd. minjust.gov.kg/act/view/ru-ru/1070 [dostęp: 12.05.2019].

24 Н.С. Турсунбаева, Аеятельность судов аксакалов в Кыргызской Республике, „Вестник КРСУ” 2015, t. 2, nr 2, s. 155, https://www.krsu.edu. kg/vestnik/2016/v6/a12.pdf [dostęp: 11.08.2019]. 
w spór przed sądami powszechnymi zawierają Kodeks postępowania cywilnego Republiki Kirgiskiej z 25 stycznia 2017 r. i Kodeks Republiki Kirgiskiej o odpowiedzialności administracyjnej w nowej redakcji z 25 stycznia 2017 r. (art. 18). Możliwość polubownego załatwienia części sporów zawierają też przepisy Kodeksu pracy Republiki Kirgiskiej z 4 sierpnia 2004 r. (art. 431), Kodeksu rodzinnego Republiki Kirgiskiej z 30 sierpnia 2003 r. (art. 23) i Kodeksu karnego Republiki Kirgiskiej z 1 października 1997 r. (art. 66) $)^{25}$.

W Uzbekistanie podstawy prawne instytucji sądów polubownych stanowi ustawa z dnia 16 października 2006 r. o sądach polubownych, która weszła w życie 1 stycznia 2007 r. oraz regulamin Stałego Sądu Polubownego przy Centrum Badania Problemów Prawnych. Regulamin ten został zatwierdzony uchwałą Walnego Zgromadzenia pracowników Centrum Badań Problemów Prawnych z dnia 10 stycznia 2007 r. ${ }^{26}$ Przepisy regulujące możliwość podjęcia postępowania polubownego są również zawarte w Kodeksie rodzinnym Republiki Uzbekistanu z dnia 30 kwietnia 1997 r. (art. 40), Kodeksie karnym Republiki Uzbekistanu z dnia 22 września 1994 r. (art. 51, 71 i 61 ust. 1), a także Kodeksie cywilnym Republiki Uzbekistanu z 21 grudnia 1995 r. W tym ostatnim szereg przepisów pozwala na podjęcie postępowania polubownego na każdym etapie postępowania

25 С.А. Тюльканов, К.В. Геворкова, ор.cit., s. 152.

26 Zоb. Закон Республики Узбекистан № 3РУ-64 от 16 октября 2006 года «О третейских суАах», http://lex.uz/docs/1072094 [dostęp: 13.05.2019]; Регламент постоянно Аействующего Третейского суда при центре изучения правовых проблем, утвержден Решением Общего собрания комлектива Центра изучения правовых проблем от 10 января 2007 года, https://nrm.uz/contentf?doc=360590_reglament_postoyanno _deystvuyushchego_treteyskogo_suda_pri_centre_izucheniya_pravovyh_ problem_(utverjden_resheniem_obshchego_sobraniya_kollektiva_centra_ izucheniya_pravovyh_problem_ot_10_01_2007_g_(protokol_n_2)) [dostęp: 13.05.2019]. 
sądów powszechnych w Uzbekistanie i we wszystkich ich instancjach $^{27}$.

W Tadżykistanie, podobnie jak w Uzbekistanie, podstawy prawne sądów polubownych zagwarantowano na poziomie ustawowym. Określa je ustawa z dnia 5 stycznia 2008 r. o sądach polubownych ${ }^{28}$. Ponadto przepisy odnoszące się do postępowania polubownego są zawarte w: Kodeksie karnym Republiki Tadżykistanu z dnia 21 maja 1998 r. (art. 73), Kodeksie rodzinnym Republiki Tadżykistanu z dnia 13 listopada 1998 r. (art. 22), Kodeksie pracy Republiki Tadżykistanu z dnia 15 maja 1997 r. (art. 208 i 209), Kodeksie cywilnym Republiki Tadżykistanu z dnia 11 grudnia 1999 r. (art. 151) i Kodeksie postępowania gospodarczego Republiki Tadżykistanu z dnia 5 stycznia 2008 r. ${ }^{29}$

\section{Tworzenie i zasady działania sądów}

Sądy polubowne w Uzbekistanie, Tadżykistanie i Kirgistanie są sądami niepaństwowymi, które są powoływane za zgodną wolą stron stosunku prawnego. Ich zadaniem jest rozstrzyganie sporów cywilnych bądź gospodarczych między stronami poprzez wydanie wyroku, który ma taką samą moc prawną jak wyrok sądu państwowego. Funkcjonują tam zarówno stałe sądy polubowne, powoływane przez organizacje niekomercyjne posiadające osobowość prawną, jak i sądy polubowne powoływane doraźnie dla rozstrzygnięcia konkretnego sporu, zaistniałego między stronami stosunku prawnego. W Kirgistanie te ostatnie noszą nazwę tymczasowych sądów polubownych lub sądów „jednorazowych”.

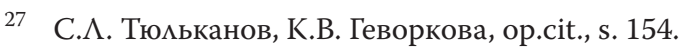

28 Закон Республики Таджикистан № 344 от 19 января 2008 года «Об третейских судах» (по состоянию на 3 июля 2012 года), http://base. spinform.ru/show_doc.fwx?rgn=21481 [dostęp: 13.05.2019].

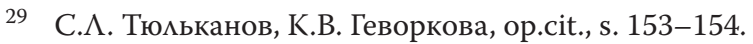


Tworzenie stałych sądów polubownych jest bardziej sformalizowane niż doraźnych sądów polubownych (dalej: doraźne sądy polubowne). W przypadku stałego sądu polubownego wymagana jest bowiem stosowna uchwała podmiotu tworzącego - osoby prawnej, dotycząca utworzenia stałego sądu polubownego, zatwierdzenia jego regulaminu i listy sędziów, czyli arbitrów. Osoba prawna, która utworzyła stały sąd polubowny zobowiązana jest też do przedłożenia kopii stosownych dokumentów we właściwym miejscowo sądzie okręgowym. Siedziba stałego sądu polubownego znajduje się zazwyczaj w siedzibie tworzącego go podmiotu. W przypadku Uzbekistanu zastrzeżono, że nie mogą być nimi jedynie organy władzy państwowej, zaś w przypadku Tadżykistanu - ani organy władzy państwowej, ani organy samorządu terytorialnego. Siedzibę stałego sądu polubownego określa obligatoryjnie jego regulamin. Wyróżnikami stałych sądów polubownych są również: własna pieczęć z nazwą sądu, sądowy blankiet oraz odrębny rachunek bankowy.

W przypadku doraźnego sądu polubownego miejsce jego posiedzenia ustalają same strony postępowania w umowie o sąd polubowny, a jeżeli brakuje takiego uzgodnienia, wówczas - zgodnie z przepisami ustawy - należy to do kompetencji sądu, który uwzględnia dogodność dostępu do miejsca sądu dla obydwu stron postępowania. W Kirgistanie ustawodawca dodaje jeszcze inne okoliczności, jak: dogodność dojazdu do sądu ze strony świadków, dostępność do dokumentów i składników majątkowych, będących przedmiotem sporu ${ }^{30}$.

Do powołania sądu polubownego wymagana jest pisemna forma umowy stron stosunku prawnego. Strony mogą zawrzeć umowę o sąd polubowny w odniesieniu do wszystkich lub tylko niektórych sporów, które powstały lub mogą powstać mię-

30 Por. Закон Респубцики Узбекистан № 3РУ-64..., op.cit., art. 5-7, 26; Закон Республики Таджикистан № 344..., op.cit., art. 3; Закон Кыргызской Респубиики № 135..., op.cit., art. 3-5, 17. 
dzy nimi w związku ze stosunkami cywilnoprawnymi. Umowa o powołanie sądu polubownego może być zawarta w formie klauzuli do umowy cywilnoprawnej lub jako oddzielne porozumienie stron. Umowa o powołanie sądu polubownego powinna zawierać: określenie stron sporu; przedmiotu sporu; nazwę sądu polubownego (tylko w przypadku stałych sądów polubownych); liczbę, imiona i nazwiska wybranych arbitrów; termin rozstrzygnięcia sporu oraz miejsce i termin zawarcia umowy. Doraźny sąd polubowny funkcjonuje tylko do czasu rozstrzygnięcia konkretnego sporu, do którego został powolany ${ }^{31}$.

Działalność sądów polubownych w Uzbekistanie, Kirgistanie i Tadżykistanie opiera się na następujących zasadach: legalizmu, dobrowolności, poufności informacji, niezależności i bezstronności arbitrów, dyspozycyjności i równości stron postępowania. Sądy polubowne tych państw rozstrzygają spory w oparciu o przepisy ich konstytucji, ustawodawstwa, w tym przede wszystkim w oparciu o ustawy o sądach polubownych, akty międzynarodowe, których stronami są wyżej wskazane państwa, a także miejscowe tradycje ${ }^{32}$.

Szczególną odmianą sądów polubownych są sądy aksakałów, funkcjonujące obecnie tylko w Kirgistanie. Różnią się one znacząco od pozostałych sądów polubownych ze względu na sposób powołania, zakres przedmiotowy rozpoznawanych przez nie sporów, skład sądu, sposób doręczeń, formy procedowania i treść wydawanych orzeczeń. Sądy aksakałów działają bowiem na zasadach organizacji społecznych, a ich członków wybierają na okres trzech lat w głosowaniu jawnym

31 Por. Закон Республики Узбекистан № 3РУ-64..., op.cit., art. 11-13; Закон Республики Таджикистан № 344..., op.cit., art. 3 і 6; Закон Кыргызской Республики № 135..., op.cit., art. 6.

32 Рor. Закон Республики Узбекистан № 3РУ-64..., op.cit., art. 4 i 10; Закон Республики Таджикистан № 344..., op.cit., art. 5 i 21; Закон Кыргызской Респубкики № 135..., op.cit., art. 4 i 6. 
zgromadzenia wspólnot terytorialnych obywateli oraz rady deputowanych w okręgach wiejskich i miastach ${ }^{33}$. Członek sądu aksakałów po upływie trzyletniego okresu pełnomocnictw może być wybrany ponownie. Na jeden okręg wiejski - ajyłny ajmak przypada jeden sąd aksakałów, zaś w miastach tworzenie tych sądów uzależnione jest od liczby ich mieszkańców według zasady: jeżeli liczba mieszkańców jest większa niż 25 tys., to przypada jeden sąd aksakałów, w miastach liczących od 25 tys. do 50 tys. mieszkańców - dwa sądy aksakałów i przy każdym następnym rosnącym przedziale liczby mieszkańców o 25 tys. - dochodzi jeszcze jeden sąd aksakałów ${ }^{34}$. Według stanu na 2014 r. w Kirgistanie funkcjonowało 831 sądów aksakałów, z czego $750 \mathrm{w}$ okręgach wiejskich i $81 \mathrm{w}$ miastach ${ }^{35}$.

Miejscem posiedzeń sądów aksakałów są ustawowo pomieszczenia wydzielone przez jednostki samorządu terytorialnego, chyba że przewodniczący sądu wyznaczy inne miejsce posiedzenia sądu. Jednostki samorządowe zapewniają też zabezpieczenie techniczno-materiałowe sądów aksakałów ${ }^{36}$.

Do podstawowych zadań sądów aksakałów ustawa zalicza: ochronę naruszonych praw i interesów prawnych obywateli, przyczynianie się do utrzymania porządku prawnego i zapobieganie jego naruszaniu na terenie ajylnych ajmaków i miast oraz kształtowanie u obywateli poszanowania dla prawa, norm

33 W kontekście dość skomplikowanej i specyficznej organizacji samorządu terytorialnego w Kirgistanie oraz nazewnictwa jego jednostek należy wyjaśnić, że rady deputowanych, określane również jako rady terytorialne lub lokalne, są przedstawicielskimi organami samorządu terytorialnego w tym państwie. W zależności od charakteru osiedli dzielą się one na rady ajyłne tworzone w okręgach wiejskich, które obejmują mieszkańców wsi i osad miejskich, tzw. ajyłnych ajmaków, oraz rady miejskie tworzone w okręgach miejskich. Szerzej zob. J. Szukalski, System konstytucyjny..., op.cit., s. 142-146.

34 Закон Кыргызской Республики № 113..., op.cit., art. 10-11.

35 А.В. Аогинов, Адат и шариат..., ор.сit., s. 3.

36 Закон Кыргызской Республики № 113..., op.cit., art. 17. 
moralnych, a także obyczajów i tradycji narodów zamieszkujących Kirgistan. Do sądów aksakałów mogą zwracać się o rozstrzygnięcie sporu nie tylko obywatele Kirgistanu, lecz również sądy, prokuratura i inne organy ochrony prawnej tego państwa w celu alternatywnego rozstrzygnięcia sprawy „w zgodności z obowiązującym ustawodawstwem Republiki Kirgiskiej" ${ }^{37}$.

Do właściwości rzeczowej sądów aksakałów należą sprawy dotyczące sporów majątkowych i rodzinnych obywateli, a w ich zakresie sprawy o: odzyskiwanie długów majątkowych, zwrot mienia znajdującego się w nielegalnym posiadaniu osób trzecich, zwrot mienia przekazanego do przechowywania, płatności czynszowe, odszkodowanie za szkodę majątkową, zniesienie współwłasności małżonków. Sądy aksakałów zajmują się też sprawami dotyczącymi: niewypełniania przez rodziców i innych członków rodziny obowiązków związanych z wychowaniem i utrzymaniem dzieci; niewypełniania przez dorosłe dzieci obowiązków związanych z utrzymaniem niepełnosprawnych rodziców lub rodziców w podeszłym wieku, a także analogicznych obowiązków wobec opiekunów tych dzieci; wynagrodzenia za pracę wykonaną na podstawie umowy o pracę; sporów między współwłaścicielami nieruchomości; przemocy domowej. Do ich właściwości należą również sprawy karne o niewielkiej szkodliwości społecznej, za które przewidziane są kary niezwiązane z pozbawieniem wolności ${ }^{38}$.

W rozpatrywaniu spraw sądy aksakałów mogą się kierować nie tylko przepisami Konstytucji Kirgistanu, ustaw i innych aktów normatywnych, ale także własnym sumieniem i przekonaniami, zasadami Koranu oraz normami moralnymi i obyczajowymi, o ile są one zgodne $\mathrm{z}$ ustawodawstwem Kirgistanu ${ }^{39}$.

37 Ibidem, art. 1 i 3.

38 Ibidem, art. 15.

39 Ibidem, art. 2; L. Leszczenko, Instytucja ombudsmana w państwach poradzieckich: geneza - status prawny - rozwój, Warszawa 2011, s. 93-94. 


\section{Skład sądu polubownego}

Ustawy o sądach polubownych Uzbekistanu, Kirgistanu i Tadżykistanu uzależniają skład sądu polubownego od jego charakteru, tzn. czy jest on stały, czy doraźny. Skład stałych sądów polubownych określają przede wszystkim ich regulaminy, chociaż niemały wpływ na to mają też strony sporu cywilnoprawnego. Sędziowie stałych sądów polubownych są wybierani przez osoby prawne, które powołały dany sąd. Strony sporu mogą zatem wskazywać sędziów tylko z listy danego stałego sądu polubownego. Skład doraźnych sądów polubownych zaś kształtują w pierwszej kolejności same strony sporu cywilnoprawnego w umowie o sąd polubowny. Jeżeli jednak w umowie nie określono składu sądu polubownego - wówczas jest on kształtowany przepisami ustawy.

W Uzbekistanie w skład pierwszego stałego sądu polubownego, którym jest wskazany już wyżej Stały Sąd Polubowny przy Centrum Badania Problemów Prawnych w Taszkencie (dalej: Stały Sąd Polubowny), utworzony 29 listopada 2002 r., czyli jeszcze przed przyjęciem stosownej ustawy regulującej tworzenie i działalność sądów polubownych w tym państwie, weszło jedenastu arbitrów - w tym przewodniczący, jego zastępca i sekretarz ${ }^{40}$. Przewodniczący i jego zastępca są wybierani przez arbitrów spośród ich grona, zaś sekretarz jest wybierany przez przewodniczącego. Ponadto w skład Stałego Sądu Polubownego wchodzą pracownicy techniczni ${ }^{41}$.

40 Официальный сайт Центра изучения правовых проблем Республики Узбекистан, Третейский суд при Центре изучения правовых проблем, http://www.lprc.uz/treteyskiy.html [dostęp: 12.08.2019].

41 Регламент постоянно Аействующего Третейского суда при центре..., op.cit., art. 4-5. 
Regulamin Stałego Sądu Polubownego wymaga, aby arbitrzy legitymowali się wyższym wykształceniem, mieli ukończone 25 lat, a także posiadali cechy charakteru pozwalające na pełnienie funkcji arbitra. Jednocześnie Regulamin wyszczególnia okoliczności, które eliminują objęcie funkcji arbitra Stałego Sądu Polubownego. Należą do nich: ubezwłasnowolnienie całkowite lub częściowe, prawomocny wyrok karny oraz ustanie pełnomocnictw sędziego, adwokata, notariusza, prokuratora, śledczego lub innego funkcjonariusza organów ochrony prawnej w związku z popełnieniem przestępstwa niedającego się pogodzić z charakterem wykonywanego zawodu przez kandydata ubiegającego się o objęcie funkcji arbitra ${ }^{42}$.

Spory są rozstrzygane przez jednego lub trzech arbitrów. W przypadku składu jednoosobowego od arbitra wymagane jest wyższe wykształcenie prawnicze, zaś w przypadku składu wieloosobowego takie wykształcenie powinien posiadać jego przewodniczący. Jeżeli strony sporu w terminie 15 dni nie uzgodnią kandydatury przewodniczącego składu sądu, wówczas jego wyboru dokonuje przewodniczący Stałego Sądu Polubownego ${ }^{43}$. W Tadżykistanie i Kirgistanie regulacje dotyczące składów stałych sądów polubownych są w zasadzie analogiczne i nie zawierają one jedynie ograniczeń związanych $\mathrm{z}$ wiekiem kandydata na arbitra.

W Uzbekistanie, Tadżykistanie i Kirgistanie strony sporu same określają w umowie o sąd polubowny skład doraźnego sądu polubownego, tzn. liczbę arbitrów i porządek formowania składu sędziowskiego. Ustawy trzech wskazanych państw zastrzegają jedynie, że liczba arbitrów, stanowiących skład sądu, musi być nieparzysta. Ponadto $\mathrm{w}$ Tadżykistanie strony sporu cywilnoprawnego mogą określić również kwalifikacje specjal-

\footnotetext{
42 Ibidem, art. 6.

43 Закон Республики Узбекистан № 3РУ-64..., op.cit., art. 15.
} 
ne arbitrów - jeśli wymaga tego specyfika sprawy. Jeżeli strona sporu w terminie 15 dni od otrzymania pisemnej prośby od drugiej strony sporu, o dokonanie wyboru arbitra lub arbitrów, nie dokona ich wyboru lub w razie, gdyby wybrani już przez strony arbitrzy w ciągu 15 dni nie wybrali swojego przewodniczącego, to umowa o sąd polubowny wygasa, zaś sprawa należy do rozpoznania kompetentnego sądu. W Kirgistanie w takim wypadku każda ze stron sporu może się zwrócić do stałego sądu polubownego o dokonanie wyboru arbitra lub arbitrów i przewodniczącego tego składu. Ich wyboru dokonuje wówczas przewodniczący stałego sądu polubownego w terminie 30 dni od dnia wpłynięcia przedmiotowej prośby. W przypadku braku wskazania w umowie o sąd polubowny liczby arbitrów, wówczas ustawowo skład sędziowski liczy trzech arbitrów, przy czym każda ze stron sporu ma prawo do wyboru jednego arbitra. Wybrany w ten sposób skład arbitrów dokonuje wyboru trzeciego arbitra - przewodniczącego składu sądu ${ }^{44}$.

We wskazanych wyżej trzech państwach Azji Centralnej arbitrem doraźnego sądu polubownego może zostać osoba posiadająca zdolność procesową, niekarana i posiadająca cechy charakteru pozwalające na pełnienie funkcji arbitra. Cenzus wyższego wykształcenia prawniczego jest wymagany tylko wobec arbitrów występujących w jednoosobowych składach orzekających oraz pełniących funkcje przewodniczącego w wieloosobowych składach orzekających. W Uzbekistanie ustawodawca wprowadził ponadto cenzus wiekowy - konieczność ukończenia 25. roku życia. W odniesieniu do zawodów, których wykonywanie eliminuje pełnienie funkcji arbitra, ustawodawca tadżycki stanowi jedynie lakonicznie, że funkcji arbitra nie może pełnić tam pracownik prokuratury. W Kirgistanie ustawa o sądach polubownych stanowi, że arbi-

44 Por. ibidem, art. 15; Закон Республики ТаАжикистан № 344..., op.cit., art. 7-9; Закон Кыргызской Республики № 135..., op.cit., art. 9. 
trem nie mogą być sędziowie i urzędnicy państwowi. Z kolei ustawodawca uzbecki wyklucza od pełnienia funkcji arbitra osoby, które wykonywały zawód sędziego, adwokata, notariusza, śledczego, prokuratora i innego funkcjonariusza organów ochrony prawnej, jeżeli osoby te zostały skazane prawomocnym wyrokiem karnym za przestępstwo popełnione w związku z wykonywaniem tych zawodów ${ }^{45}$.

Ustawowe przyczyny wyłączenia arbitra doraźnego sądu polubownego są identyczne jak w przypadku arbitra stałego sądu polubownego. Strony mogą się na nie powoływać tylko do czasu rozstrzygnięcia w sprawie. Jeżeli jedna ze stron postępowania polubownego sprzeciwia się wyłączeniu arbitra, wówczas decyzję o wyłączeniu arbitra podejmują pozostali arbitrzy wchodzący w skład sądu polubownego ${ }^{46}$.

Pełnomocnictwa arbitra doraźnego sądu polubownego wygasają: w Uzbekistanie z chwilą zakończenia postępowania polubownego, w Tadżykistanie po upływie 15 dni od zakończenia postępowania polubownego lub podjęcia decyzji w sprawie odwołania się w tym przedmiocie, zaś w Kirgistanie po upływie 60 dni od zakończenia postępowania polubownego; w razie śmierci arbitra; na zgodny wniosek stron postępowania polubownego; w wyniku wyłączenia arbitra na wniosek jednej ze stron postępowania polubownego lub samowyłączenia się arbitra ${ }^{47}$.

Skład sądów aksakałów określa ustawa. Stanowi ona, że w skład tych sądów wchodzi nieparzysta liczba członków -

45 Рor. Закон Кыргызской Республики № 135..., op.cit., art. 8; Закон Республики Таджикистан № 344..., op.cit., art. 7; Закон Республики Узбекистан № 3РУ-64..., aоp.cit., rt. 14.

46 Por. Закон Республики Узбекистан № 3РУ-64..., op.cit., art. 16; 3акон Республики Таджикистан № 344..., aоp.cit., rt. 10; Закон Кыргызской Республики № 135..., op.cit., art. 10-11.

47 Zob. Закон Республики Узбекистан № 3РУ-64..., op.cit., art. 18; Закон Кыргызской Республики № 135..., op.cit., art. 12; Закон Республики Таджикистан № 344..., op.cit., art. 12. 
nie mniejsza niż pięciu i nie większa niż dziewięciu, w tym przewodniczący sądu. Jest on wybierany przez członków sądu aksakałów spośród jego gremium ${ }^{48}$. Zgodnie z wymogami ustawowymi członkami sądów aksakałów mogą być obywatele Kirgistanu, którzy ukończyli 50. lat, posiadają wykształcenie średnie ogólne, stałe miejsce zamieszkania w okresie co najmniej pięciu ostatnich lat przed kandydowaniem, niekarani, cieszący się autorytetem w lokalnej społeczności ajyłnego ajmaku lub miasta, a także zdolni do wykonywania zadań stawianych przed sądami aksakałów. Od przewodniczącego sądu aksakałów wymagane jest dodatkowo wyższe wykształcenie prawnicze ${ }^{49}$. Należy dodać, że do 2009 r. skład sądów aksakałów stanowili wyłącznie mężczyźni. Dopiero nowelizacja ustawy o sądach aksakałów, przyjęta w dniu 12 czerwca 2009 r., pozwoliła kobietom na pełnienie funkcji członka sądów aksakałów. Krok ten był nie tylko wyrazem normatywnej realizacji standardów równego statusu kobiet i mężczyzn w Kirgistanie, przełamując dotychczasowy i zgodny z tradycją monopol mężczyzn na zasiadanie w sądach aksakałów, ale także pozytywnie wpłynął na merytoryczną pracę tych sądów. Dotyczy to zwłaszcza spraw rodzinnych, które ze względu na swoją specyfikę wymagają oceny ze strony obydwu płci ${ }^{50}$.

W rozpoznaniu sprawy przez sąd aksakałów nie może uczestniczyć członek sądu, który jest bliskim krewnym jednej ze stron sporu, a także jeżeli jest on w jakikolwiek sposób zainteresowany wynikiem rozstrzygnięcia sporu. Wyłączenie

48 Закон Кыргызской Респубцики № 113..., op.cit., art. 8.

49 Ibidem, art. 9.

50 Zob. Закон Кыргызской Респубцики № 181 от 12 июня 2009 года «О внесении изменения и Аополнения в Закон Кыргызской Респубцики „О суАах аксакамов”», http://cbd.minjust.gov.kg/act/view/ ru-ru/202583?cl=ru-ru [dostęp: 26.08.2019]; Lenta.ru, В Киргизии в суды аксакалов пустят жениин, https://lenta.ru/news/2009/04/24/women/ [dostęp: 28.08.2019]. 
w takich wypadkach następuje na wniosek strony sporu, jednego z członków sądu aksakałów lub samego członka tegoż sądu, który podlega wyłączeniu. Decyzję w tym przedmiocie podejmuje sąd aksakałów większością głosów swojego składu.

Przyczynami ustania pełnomocnictw członka sądu aksakałów są: odmowa pełnienia funkcji członka sądu aksakałów, śmierć lub uznanie za zmarłego, upływ okresu pełnomocnictw, zmiana miejsca zamieszkania, prawomocny wyrok karny oraz odwołanie członka sądu aksakałów. Powodami odwołania przez zgromadzenia wspólnot terytorialnych obywateli i rady deputowanych mogą być: niewypełnianie obowiązków członka sądów akasakałów, naruszenie porządku publicznego i inne czyny nielicujące z powagą pełnionej funkcji ${ }^{51}$.

Sposób wyboru i odwołania członków sądów aksakałów, w kontekście funkcjonujących w Kirgistanie układów trybalnych, nasuwa uzasadnione wątpliwości co do ich niezależności i bezstronności. Zgromadzenia wspólnot terytorialnych i rady deputowanych, podobnie zresztą jak wszystkie pozostałe struktury samorządowe w tym państwie, są bowiem zdominowane przez lokalne klany, które mają niekwestionowany wpływ na wybór i odwołanie członków sądów aksakałów, zaś ci ostatni - w myśl aksjologii trybalnej - są „zobowiązani” do okazania lojalności i wdzięczności. Zastrzeżenia można mieć również do braku ustawowego wymogu wykształcenia prawniczego członków sądów aksakałów, za wyjątkiem ich przewodniczących, zważywszy na zakres rzeczowy rozpatrywanych przez te sądy spraw. W doktrynie prawa konstytucyjnego w Kirgistanie pojawiają się w związku z tym coraz częściej głosy krytyczne z sugestią wprowadzenia obowiązkowych szkoleń dla członków sądów aksakałów ${ }^{52}$. Problem braku odpowied-

51 Закон Кыргызской Республики № 113..., op.cit., art. 13-14.

52 К.Б. ШаАыбеков, Аечентрализованные формы осуществления правосудия в контексте развития институтов судов аксакалов 
nich kwalifikacji ma zresztą szerszy wymiar, bowiem dotyczy on również arbitrów sądów polubownych w Uzbekistanie, Tadżykistanie i Kirgistanie. Wymóg wykształcenia prawniczego jedynie w odniesieniu do przewodniczących sądów polubownych to jednak za mało, aby zapewnić prawidłowy przebieg postępowań polubownych, zwłaszcza w przypadku spraw zawiłych czy absencji przewodniczącego.

\section{Postępowanie przed sądem}

Wszczęcie postępowania polubownego następuje $\mathrm{z}$ chwilą wniesienia pozwu do sądu polubownego. W każdym z państw Azji Centralnej wymagana jest pisemna forma pozwu, który powinien spełniać określone wymogi formalne. Należą do nich: data pozwu; nazwa i miejsce sądu polubownego, gdy jest to stały sąd polubowny; podstawowe dane dotyczące stron procesowych, tj. powoda i pozwanego - w przypadku osób prawnych są wymagane ich nazwa i adres siedziby, zaś w odniesieniu do osób fizycznych - ich imiona, nazwiska (nazwiska rodowe) i adresy zamieszkania, a w Tadżykistanie także miejsce pracy; porozumienie polubowne lub umowa o przekazanie sporu pod rozstrzygnięcie sądu polubownego; żądania pozwu, ich uzasadnienie i dowody potwierdzające żądania pozwu; wartość przedmiotu sporu oraz załączniki. Wśród załączników wymagana jest kopia pozwu, którą sąd polubowny przesyła pozwanemu. Pozew musi być podpisany przez powoda lub jego pełnomocnika. Jeżeli pozew jest podpisany przez

Кыргызстана, „Юридическая наука” 2019, nr 2, s. 3-5, https://cyberleninka.ru/article/n/detsentralizovannye-formy-osuschestvleniya-pravosudiya-v-kontekste-razvitiya-institutov-sudov-aksakalov-kyrgyzstana [dostęp: 28.08.2019]; Н.С. Турсунбаева, Аеятельность судов..., ор.сіt., s. 156-157; Ж. Тороев, Суды аксакалов в Кыргыззтане, «Юрист” 2005, nr 1, https:// journal.zakon.kz/203709-sudy-aksakalov-v-kyrgyzstane.html [dostęp: 28.08.2019]. 
pełnomocnika wymagane jest również załączenie dokumentu potwierdzającego pełnomocnictwo ${ }^{53}$.

W Uzbekistanie, Tadżykistanie i Kirgistanie w postępowaniu cywilnym osoby fizyczne lub ich przedstawiciele ustawowi mogą działać osobiście lub przez pełnomocnika. Ustanowienie pełnomocnika jest konieczne w przypadku braku zdolności postulacyjnej, wynikającej z przyczyn natury faktycznej lub prawnej. Rolę pełnomocników w wymienionych państwach pełnią przede wszystkim adwokaci. Jeżeli osoba fizyczna nie ma zdolności procesowej działa za nią przedstawiciel ustawowy, którego umocowanie wynika z ustawy lub z orzeczenia sądu. Natomiast osoby prawne są tam reprezentowane przez ich organy ${ }^{54}$.

Pozwany w postępowaniu polubownym ma prawo do złożenia pisemnej odpowiedzi na pozew lub wniesienia powództwa wzajemnego. Jeżeli termin na złożenie odpowiedzi nie został określony, to ustawowo przyjmuje się, że przysługuje

53 Por. Закон Республики Узбекистан № 3РУ-64..., op.cit., art. 29; Закон Республики Таджикистан № 344..., op.cit., art. 17; Закон Кыргызской Республики № 135..., op.cit., art. 20.

54 Regulacje dotyczące reprezentacji osób fizycznych i prawnych w postępowaniu cywilnym w Uzbekistanie, Tadżykistanie i Kirgistanie są zawarte w Kodeksach cywilnych i Kodeksach postępowania cywilnego tych państw. Zob. ГражАанский кодекс Республики Узбекистан № 163-I от 21 декабря 1995 года (по состоянию на 23 мая 2019 года), art. 16-57, 129-144, http://lex.uz/acts/111181 [dostęp: 17.08.2019]; ГражАанский процессуальный кодекс Республики Узбекистан № 3РУ-460 от 22 января 2018 года (по состоянию на 10 мая 2019 года), art. 65-70, http://lex.uz/ docs/3517334 [dostęp: 17.08.2019]; ГражАанский кодекс Респубкики ТаАжикистан от 30 июня 1999 года (по состоянию на 2 января 2019 года), art. 17-68, 207-214, http://base.spinform.ru/show_doc.fwx?rgn=2142 [dostęp: 17.08.2019]; ГражАанский процессу - альный кодекс Республики Таджикистан от 5 января 2008 года (по состоянию на 202019 года), art. 50-56, 207-214, http://base.spinform.ru/show_doc.fwx?rgn=21129 [dostęp: 17.08.2019]; ГражАанский кодекс Кыргызской Республики № 16 от 8 мая 1996 года (по состоянию на 6 августа 2018 года), art. 51-104, 200-206, https://online.zakon.kz/document/?doc_id=30212538 [dostęp: 17.08.2019]; ГражАанский процессу - альный кодекс Кыргызской Республики № 14 от 25 января 2017 года (по состоянию на 17 мая 2018 года), art. 52-58, http://base.spinform.ru/show_doc.fwx?rgn=94089 [dostęp: 17.08.2019]. 
on pozwanemu do rozpoczęcia pierwszego posiedzenia sądu polubownego w przedmiotowej sprawie. Natomiast powództwo wzajemne można wnieść na każdym etapie postępowania polubownego aż do wydania orzeczenia przez sąd polubowny.

Strony mogą żądać zabezpieczenia powództwa w przypadku, jeżeli jego spełnienie mogłoby utrudnić bądź uniemożliwić wykonanie orzeczenia sądu polubownego, do czego potrzebne jest złożenie przez stronę powodową stosownego wniosku do kompetentnego sądu. Sądem właściwym miejscowo w tym przedmiocie jest sąd rejonowy siedziby sądu polubownego lub miejsca zamieszkania pozwanego bądź miejsca, w którym znajduje się majątek pozwanego ${ }^{55}$.

Postępowanie przed sądem polubownym jest prowadzone w języku państwowym, o ile strony nie umówiły się w tym względzie inaczej. Strona, która przedłożyła w sądzie dokumenty $\mathrm{i}$ inne materiały w języku innym niż państwowy, jest zobowiązana do zabezpieczenia ich przetłumaczenia na język państwowy lub język uzgodniony przez strony jako język postępowania polubownego. Sam sąd polubowny ma prawo do wezwania stron w celu zabezpieczenia tłumaczenia dokumentów i innych materiałów na język przyjęty w postępowaniu polubownym ${ }^{56}$.

Ustawodawca nałożył na arbitra obowiązek zachowania bezstronności przy prowadzeniu postępowania oraz zachowania w tajemnicy faktów, o których dowiedział się w związku z prowadzonym postępowaniem. Arbiter nie może też występować w charakterze świadka i zeznawać co do okoliczności znanych mu z prowadzonego postępowania polubownego.

55 Por. Закон Респубцики Узбекистан № 3РУ-64..., op.cit., art. 30-32; Закон Респубкики Таджикистан № 344..., op.cit., art. 17-18; Закон Кыргызской Республики № 135..., op.cit., art. 21-22.

56 Рor. Закон Республики Узбекистан № 3РУ-64..., op.cit., art. 27; 3акон Республики Таджикистан № 344..., op.cit., art. 24; Закон Кыргызской Республики № 135..., op.cit., art. 18. 
Zasadniczo posiedzenia w postępowaniu polubownym odbywają się z udziałem stron lub ich pełnomocników, chyba że strony w umowie o sąd polubowny umówiły się inaczej. Jeżeli brak jest porozumienia stron w tym przedmiocie, wówczas sąd samodzielnie decyduje o porządku obrad. W przypadku udziału stron w posiedzeniach sądu, do obowiązku sądu należy właściwe zabezpieczenie powiadomienia stron o terminie i miejscu posiedzenia, a także doręczeniu kopii dokumentów i innych pism procesowych stronie pozwanej przy wykorzystaniu poczty i formy listu poleconego. $Z$ reguły posiedzenia sądu polubownego są niejawne, o ile strony nie umówiły się w tym względzie inaczej ${ }^{57}$.

Strony są zobligowane do przedstawienia przed sądem polubownym dokumentów i innych dowodów, na których opierają swoje roszczenia. W przypadku gdy sąd uzna, że materiał dowodowy jest niewystarczający może zarządzić jego uzupełnienie przez stronę bądź strony. W razie konieczności odwołania się do wiedzy specjalistycznej sąd może z urzędu lub na wniosek strony zarządzić sporządzenie ekspertyzy przez specjalistę lub specjalistów z danej dziedziny wiedzy ${ }^{58}$.

Na każdym etapie postępowania polubownego aż do wydania w nim orzeczenia sąd może nakłaniać strony do mediacji. Jeżeli strony zgodzą się na mediację, to postępowanie polubowne jest zawieszane do zakończenia mediacji. Zawarcie przez strony ugody w drodze mediacji kończy postępowanie polubowne. Z przeprowadzonego posiedzenia sądu polubownego sporządzany jest protokół, o ile strony nie umówiły się w tym względzie inaczej. W protokole wymagane są podpisy

57 Рor. Закон Республики Узбекистан № 3РУ-64..., op.cit., art. 35; Закон Республики Таджикистан № 344..., op.cit., art. 28-30; Закон Кыргызской Республики № 135..., op.cit., art. 24.

58 Por. Закон Респубцики Узбекистан № 3РУ-64..., op.cit., art. 34; 3акон Республики Таджикистан № 344..., ор.cit., art. 28-29; Закон Кыргызской Респубкики № 135..., op.cit., art. 25-26. 
wszystkich arbitrów biorących udział w postępowaniu polubownym oraz sekretarza, który sporządził protokół ${ }^{59}$.

Postępowanie polubowne może zakończyć się w sposób niemerytoryczny poprzez umorzenie postępowania albo w sposób merytoryczny, gdy sąd wyda orzeczenie. Przyczynami umorzenia postępowania polubownego są: cofnięcie pozwu przez powoda przy braku sprzeciwu pozwanego, zatwierdzenie przez sąd ugody zawartej przez strony sporu, śmierć bądź uznanie za zmarłego powoda lub pozwanego, zawarcie przez strony porozumienia o wycofaniu się z polubownego rozstrzygnięcia sporu, niewłaściwość rzeczowa sądu do rozstrzygnięcia sporu. W przypadku zawiłości sprawy sąd polubowny wyznacza przed wydaniem orzeczenia dodatkowe posiedzenie, na które wzywa strony lub ich pełnomocników.

Po zamknięciu posiedzenia sąd polubowny wydaje orzeczenie, biorąc za podstawę stan rzeczy istniejący w chwili zamknięcia posiedzenia. Jeżeli skład sądu jest wieloosobowy, orzeczenie zapada większością głosów. Arbiter, który nie zgodził się z większością, może przy podpisaniu sentencji zgłosić zdanie odrębne, co wymaga jego pisemnego uzasadnienia. W sentencji orzeczenia należy wymienić: datę wydania orzeczenia; skład i miejsce sądu polubownego; dane stron sporu, tj. w przypadku osób fizycznych ich imiona, nazwiska, miejsce urodzenia, miejsce pracy i miejsce zatrudnienia, zaś w przypadku osób prawnych - ich nazwę i adres siedziby; oznaczenie przedmiotu sporu oraz rozstrzygnięcie sądu o żądaniach stron z podaniem dowodów, na których opierają się ustalenia faktyczne sądu, a także podaniem ustaw i innych aktów normatywnych oraz norm zwyczajowych, stanowiących podstawę prawną wydanego orzeczenia; określenie kosztów sądowych

59 Por. Закон Республики Узбекистан № 3РУ-64..., op.cit., art. 36-37; Закон Респубкики ТаАжикистан № 344..., op.cit., art. 30; Закон Кыргызской Респубцики № 135..., op.cit., art. 27. 
i stosowne ich rozdzielenie między stronami sporu; w razie konieczności termin i porządek wykonania orzeczenia.

W Uzbekistanie sąd polubowny przesyła stronom sporu orzeczenie w terminie 10 dni od jego wydania, $w$ Tadżykistanie w ciągu 15 dni, zaś w Kirgistanie w ciągu pięciu dni. W terminie 10 dni od otrzymania orzeczenia przez stronę sporu może ona wystąpić z umotywowanym wnioskiem o uzupełnienie orzeczenia przez sąd polubowny w odniesieniu do żądań pozwu, które zostały pominięte przez sąd. Czynność ta wymaga powiadomienia drugiej strony sporu. W przypadku uwzględnienia żądania strony sąd polubowny wydaje orzeczenie uzupełniające, które staje się częścią składową wydanego wcześniej orzeczenia ${ }^{60}$.

W Uzbekistanie i Tadżykistanie ustawodawca przewidział możliwość zaskarżania orzeczeń sądów polubownych, zaś w Kirgistanie orzeczenia sądów polubownych są ostateczne i nie przysługują od nich żadne środki odwoławcze. W Uzbekistanie i Tadżykistanie strona sporu może w terminie $10 \mathrm{dni}$ od otrzymania orzeczenia sądu polubownego wystąpić z wnioskiem o sporządzenie uzasadnienia orzeczenia, o czym należy powiadomić drugą stronę sporu. W Uzbekistanie stronie sporu przysługuje prawo do „zakwestionowania” orzeczenia sądu polubownego w całości lub w części w terminie 30 dni od jego otrzymania. W tym celu należy wnieść stosowny wniosek do właściwego sądu rejonowego ds. cywilnych lub sądu miejskiego ds. cywilnych z żądaniem zmiany orzeczenia sądu polubownego w odniesieniu do całości tegoż orzeczenia lub zakwestionowanej jego części. W Uzbekistanie powodami zaskarżenia orzeczenia sądu polubownego są: orzeczenie, które nie dotyczy sporu przewidzianego $\mathrm{w}$ umowie o sąd polubowny

60 Por. Закон Республики Узбекистан № 3РУ-64..., op.cit., art. 38-40; Закон Республики Таджикистан № 344..., op.cit., art. 32-36; Закон Кыргызской Респубиики № 135..., op.cit., art. 31-33. 
lub orzeczenie wykraczające poza ramy porozumienia o sąd polubowny; orzeczenie naruszające ustawodawstwo Uzbekistanu; obsada sądu polubownego nie wypełniła wymogów ustawy, określonych w przepisach jej art. 14-16 i 25; strona postępowania polubownego była nienależycie powiadomiona o miejscu i terminie posiedzenia sądu polubownego, wskutek czego nie mogła przedstawić swojego stanowiska.

W Tadżykistanie orzeczenie sądu polubownego można zaskarżyć tylko wówczas, jeżeli umowa o sąd polubowny nie przewiduje, że orzeczenie to będzie miało charakter ostateczny. Termin na zaskarżenie orzeczenia sądu polubownego wynosi trzy miesiące. Sądem właściwym do złożenia wniosku w tym przedmiocie jest sąd rejonowy lub sąd miejski miejsca funkcjonowania sądu polubownego, który wydał zaskarżone orzeczenie $^{61}$. Powodami zaskarżenia orzeczenia sądu polubownego, określonymi w Kodeksie Republiki Tadżykistanu o sądownictwie gospodarczym z dnia 5 stycznia 2008 r., są: sprzeczność orzeczenia z ustawodawstwem Tadżykistanu; nienależyte powiadomienie strony sporu o terminie i miejscu posiedzenia sądu polubownego lub inne istotne przyczyny, które miały wpływ na brak możliwości przedstawienia swojego stanowiska przez stronę sporu; skład sądu polubownego lub zastosowana przez niego procedura były sprzeczne z umową stron sporu lub przepisami ustawy; orzeczenie sądu polubownego nie dotyczy sporu przewidzianego w umowie stron o sąd polubowny lub zawiera postanowienia wykraczające poza jego ramy; rozpatrywana sprawa nie należała do kompetencji sądu polubownego ${ }^{62}$.

61 Por. Закон Респубцики Узбекистан № 3РУ-64..., op.cit., art. 46-48; Закон Республики Таджикистан № 344..., op.cit., art. 40-42; Закон Кыргызской Республики № 135..., op.cit., art. 28.

62 Zob. Экономический процессуальный кодекс Республики ТаАжикистан от 5 января 2008 года (по состоянию на 2 января 2019 года), art. 213 ust. 2-3, http://base.spinform.ru/show_doc.fwx?rgn=21131 [dostęp: 19.08.2019]. 
Należy zwrócić uwagę, że ustawy o sądach polubownych ani w Uzbekistanie, ani w Tadżykistanie nie wymieniają nazw środków zaskarżenia w postępowaniu odwoławczym, ograniczając się jedynie do użycia czasowników: „kwestionować” i „zaskarżyć”. Ponadto termin odwoławczy jest tam liczony nie od dnia doręczenia stronie uzasadnienia orzeczenia, lecz od dnia wydania orzeczenia, czyli zupełnie odmiennie niż w procedurze cywilnej państw europejskich, w tym i w polskiej procedurze cywilnej ${ }^{63}$.

Orzeczenie sądu polubownego, zarówno w Uzbekistanie, jak i w Tadżykistanie, podlega wykonaniu w terminie określonym w orzeczeniu tegoż sądu. Jeżeli jednak w orzeczeniu nie wskazano terminu jego wykonania, to podlega ono wykonaniu niezwłocznie. Orzeczenie, które nie zostało wykonane dobrowolnie, podlega przymusowemu wykonaniu w porządku określonym przez ustawodawstwo obydwu wymienionych państw ${ }^{64}$. W Uzbekistanie kwestie te reguluje ustawa z dnia 29 sierpnia 2001 r. o wykonaniu orzeczeń sądowych i innych aktów organów, zaś w Tadżykistanie ustawa z dnia 20 marca 2008 r. o postępowaniu egzekucyjnym ${ }^{65}$. W tym celu konieczny jest tytuł wykonawczy, który na podstawie przedłożonego orzeczenia sądu polubownego wydaje w Uzbekistanie sąd rejonowy ds.

63 Por. Закон Республики Узбекистан № 3РУ-64..., op.cit., art. 46; 3акон Республики Таджикистан № 344..., op.cit., art. 40; ustawa z dnia 17 listopada 1964 r. - Kodeks postępowania cywilnego, Dz.U. 1964, nr 43, poz. 296, tekst jedn., art. 367-369, 394-395, http://prawo.sejm.gov.pl/isap.nsf/ DocDetails.xsp?id=WDU19640430296 [dostęp: 18.08.2019].

64 Por. Закон Республики Узбекистан № 3РУ-64..., op.cit., art. 49-50; Закон Республики Таджикистан № 344..., op.cit., art. 45.

65 Zob. Закон Республики Узбекистан № 258-II от 29 августа 2001 года «Об исполнении суАебных актов и актов иных органов» (по состоянию на 30 июля 2019 года), http://base.spinform.ru/show_doc. fwx?rgn=883 [dostęp: 19.08.2019]; Закон Республики ТаАжикистан № 373 от 20 марта 2008 года «Об исполнительном производстве» (по состоянию на 20 июня 2019 года), http://base.spinform.ru/show_doc. fwx?rgn=22026 [dostęp: 19.08.2019]. 
cywilnych lub sąd miejski ds. cywilnych, zaś w Tadżykistanie sąd rejonowy lub sąd miejski, właściwe dla miejsca sądu polubownego, który wydał orzeczenie. W przypadku Uzbekistanu wniosek o wydanie tytułu wykonawczego może być złożony nie później niż do sześciu miesięcy od dnia upływu terminu wymagalności wykonania orzeczenia sądu polubownego ${ }^{66}$.

Rozstrzyganie sporów przez sądy polubowne wiąże się z określonymi wydatkami, które obejmują: honoraria arbitrów oraz ich wydatki związane z dojazdami do sądu; wynagrodzenie dla ekspertów i tłumaczy, a także koszty ich dojazdów do sądu; wydatki poniesione przez świadków, tj. koszty ich dojazdu do sądu oraz zwrot wysokości utraconego w związku z tym wynagrodzenia za pracę; zabezpieczenie materiałowe i koszty wynajmu lokalu w przypadku doraźnych sądów polubownych. Wysokość honorarium sędziów polubownych ustalają same strony sporu w umowie o sąd polubowny z uwzględnieniem wysokości przedmiotu sporu i zawiłości sprawy. Koszty procesowe sąd polubowny rozdziela między stronami sporu zgodnie z ich wolą, wyrażoną w umowie o sąd polubowny. Sąd polubowny może również jeszcze przed wydaniem orzeczenia zażądać od powoda wpłaty określonych środków pieniężnych na poczet kosztów postępowania ${ }^{67}$.

Postępowanie przed sądami aksakałów jest bardziej sformalizowane niż postępowanie przed sądami polubownymi omawianych wyżej państw. Wskazując na różnice należy wymienić znacznie krótsze terminy na podejmowanie czynności przez sąd i strony, specyficzną formę doręczeń pism procesowych oraz większe możliwości w zakresie orzekania.

66 Por. Закон Республики Узбекистан № 3РУ-64..., op.cit., art. 51-54; Закон Республики Таджикистан № 344..., op.cit., art. 46-47.

67 Por. Закон Республики Узбекистан № 3РУ-64..., art. 20-23; Закон Республики Таджикистан № 344..., op.cit., art. 14-15. 
Podstawę do wszczęcia postępowania przed sądem aksakałów może stanowić: pozew strony powodowej; wniosek rady deputowanych lub jej organów wykonawczych; materiały przekazane w ustanowionym porządku przez sąd, prokuraturę lub inne organy ochrony prawnej, posiadające uprawnienie do rozpatrywania spraw karnych; wniosek innego sądu aksakałów. W przeciwieństwie do sądów polubownych sąd aksakałów na jednym posiedzeniu może rozpatrywać kolejno kilka spraw. Ustawa obliguje sąd aksakałów do rozpatrzenia sprawy w terminie 15 dni. Jedynie w przypadku spraw zawiłych lub konieczności uzupełnienia materiału dowodowego termin ten może być przedłużony - jednak nie dłużej niż do 15 dni. Doręczenia pism są dokonywane przez lokalnych inspektorów milicji w terminie nie wcześniejszym niż na trzy dni przed posiedzeniem sądu ${ }^{68}$.

Posiedzenia sądów aksakałów są jawne za wyjątkiem posiedzeń dotyczących okoliczności określonych przez ustawę, do których należą: umotywowana decyzja sądu, wniosek jednej ze stron postępowania, sprawy rodzinne oraz sprawy dotyczące nieletnich poniżej 16. roku życia ${ }^{69}$.

Do prawomocności orzeczeń wydawanych przez sąd aksakałów wymagany jest skład co najmniej 2/3 jego członków. W drobnych sprawach karnych należących do właściwości sądów aksakałów mogą one stosować następujące środki karne: nałożyć pieniężną grzywnę, podać orzeczenie o ukaraniu do publicznej wiadomości, zobowiązać do przeprosin pokrzywdzonego oraz zobowiązać do naprawienia szkody materialnej. Jednocześnie ustawa zastrzega, że sąd nie może stosować nieprzewidzianych w niej środków karnych ani poniżających ludzką godność. Środki pieniężne z tytułu nakładanych grzywien trafiają do budżetu lokalnych jednostek samorządowych,

68 Закон Кыргызской Республики № 113..., op.cit., art. 16-19.

69 Ibidem, art. 6. 
z czego 70\% jest redystrybuowanych na zabezpieczenie działalności sądów aksakałów ${ }^{70}$.

Orzeczenia sądów aksakałów mogą być zaskarżane w terminie 10 dni od ich wydania w sądach rejonowych i sądach miejskich Kirgistanu, właściwych dla miejsca sądów aksakałów, które wydały zaskarżone orzeczenie. Skargi są rozpatrywane w ciągu 10 dni od ich wpłynięcia przez jednoosobowe składy sędziowskie. Sędzia sprawdza zgodność orzeczenia ze zgromadzonym w sprawie materiałem dowodowym oraz obowiązującym ustawodawstwem. W razie uchybień może on uchylić orzeczenie i przekazać sprawę sądowi aksakałów do ponownego rozpoznania lub umorzyć postępowanie ${ }^{71}$.

Orzeczenia sądów aksakałów podlegają wykonaniu w terminach określonych w orzeczeniu. W razie braku dobrowolnego wykonania orzeczenia można żądać jego przymusowego wykonania, do czego potrzebny jest tytuł wykonawczy. Jest on wydawany na wniosek strony przez właściwy sąd rejonowy lub sąd miejski, w którego okręgu wydano zaskarżone orzeczenie. Przedmiotowy wniosek może być złożony w ciągu miesiąca od upływu terminu wykonania orzeczenia sądu aksakałów ${ }^{72}$.

Podsumowując zagadnienie sądownictwa polubownego w państwach Azji Centralnej należy stwierdzić, że alternatywne formy załatwiania sporów, mające umocowanie w krajowym porządku prawnym, będą w państwach tego regionu utrzymane, ponieważ umożliwiają one szybkie i ugodowe załatwianie spraw cywilnych, a w przypadku Kirgistanu także drobnych spraw karnych. Analiza normatywna ustaw o sądach polubow-

\footnotetext{
70 Ibidem, art. 28-29.

71 Ibidem, art. 30.

72 Ibidem, art. 32.
} 
nych w Uzbekistanie, Kirgistanie i Tadżykistanie oraz ustawy o sądach aksakałów w Kirgistanie wskazuje jednak na wiele mankamentów w uregulowaniach tych aktów. Przede wszystkim należy wskazać na brak w nich wymogu wykształcenia prawniczego w odniesieniu do arbitrów sądów polubownych i członków sądów aksakałów, za wyjątkiem ich przewodniczących, co znacząco wpływa na merytoryczne możliwości pracy tych sądów. Wydaje się, że wykształcenie prawnicze arbitrów i członków sądów aksakałów jest konieczne, biorąc pod uwagę zakres przedmiotowy rozpatrywanych przez wskazane sądy spraw, niejednokrotnie ich zawiłość czy wreszcie przypadki, kiedy przewodniczący sądu jest nieobecny, co powoduje konieczność odroczenia posiedzenia.

Kolejnym istotnym problemem jest sposób wyboru i odwołania członków sądów aksakałów przez zgromadzenia obywateli i rady deputowanych, a także finansowanie działalności tych sądów przez jednostki samorządowe. Takie rozwiązania godzą w niezależność sądów aksakałów i ich członków. W realiach Kirgistanu jednostki samorządowe są bowiem opanowane przez lokalne klany, które mają oczywisty wpływ na obsadę sądów aksakałów. W związku z tym zasadne byłoby wprowadzenie finansowania sądów aksakałów z budżetu centralnego, podobnie jak ma to miejsce w przypadku sądów państwowych.

\section{Bibliografia}

\section{Akty prawne}

Конституция Кыргызской Республики принята референАумом (всенародным голосованием) 27 июня 2010 года, (В редакции Закона Кыргызской Республики № 218 от 28 Аекабря 2016 года) http://cbd.minjust.gov.kg/act/view/ ru-ru/202913?cl=ru-ru. 
Ustawa z dnia 17 listopada 1964 r. - Kodeks postępowania cywilnego, Dz.U. 1964, nr 43, poz. 296, tekst jedn., http:// prawo.sejm.gov.pl/isap.nsf/DocDetails.xsp?id=WDU196 40430296.

ГражАанский кодекс Республики Казахстан № 269-XII от 27 Аекабря 1994 года (по состоянию на 1 июля 2019 года), https://online.zakon.kz/document/?doc_id=100 6061.

ГражАанский кодекс Республики Узбекистан № 163-І от 21 Аекабря 1995 года (по состоянию на 23 мая 2019 года), http://lex.uz/acts/111181.

ГражАанский кодекс Кыргызской Респубцики № 16 от 8 мая 1996 года (по состоянию на 6 августа 2018 года), https://online.zakon.kz/document/?doc_id=30212538.

ГражАанский кодекс Республики ТаАжикистан от 30 июня 1999 года (по состоянию на 2 января 2019 года), http:// base.spinform.ru/show_doc.fwx?rgn=2142.

Закон Республики Казахстан № 148-II от 23 января 2001 года «О местном государственном управлении и самоуправмении в Республике Казахстан» (по состоянию на 3 апремя 2019 года), https://online.zakon.kz/document/?doc_ id=102 1546 .

Закон Республики Узбекистан № 258-II от 29 августа 2001 года «Об исполнении судебных актов и актов иных органов» (по состоянию на 30 июля 2019 года), http://base. spinform.ru/show_doc.fwx?rgn=883.

Закон Кыргызской Республики № 113 от 5 июця 2002 года «О судах аксакацов» (по состоянию на 27 апреця 2017 года), http://cbd.minjust.gov.kg/act/view/ru-ru/1070.

Закон Кыргызской Республики № 135 от 30 июля 2002 года «Об третейских суАах в Кыргызской Республике» (по состоянию на 11 июня 2004 года), http://cbd.min just.gov. kg/act/view/ky-kg/1092/10?cl=ky-kg. 
Закон Республики Узбекистан № ЗРУ-64 от 16 октября 2006 года «О третейских судах», http://lex.uz/docs/1072094. ГражАанский процессу - альный кодекс Республики Таджикистан от 5 января 2008 года (по состоянию на 202019 года), http://base.spinform.ru/show_doc.fwx?rgn=21129.

Экономический процессуальный кодекс Республики ТаАжикистан от 5 января 2008 года (по состоянию на 2 января 2019 года), http://base.spinform.ru/show_doc.fwx? rgn $=21131$.

Закон Республики ТаАжикистан № 344 от 19 января 2008 года «Об третейских судах» (по состоянию на 3 июля 2012 года), http://base.spinform.ru/show_doc.fwx?rgn=21 481.

Закон Респубкики Таджикистан № 373 от 20 марта 2008 года «Об исполнительном производстве» (по состоянию на 20 июня 2019 года), http://base.spinform.ru/show doc.fwx?rgn=22026.

Трудовой кодекс Туркменистана № 30-IV от 18 апреля 2009 года (по состоянию на 2 марта 2019 года), http://www. minjust.gov.tm/ru/mmerkezi/doc_view.php?doc_id= 8334 . Закон Кыргызской Республики № 181 от 12 июня 2009 года «О внесении изменения и Аополнения в Закон Кыргызской Республики „О судах аксакалов”, http://cbd. minjust.gov.kg/act/view/ru-ru/202583?cl=ru-ru.

Закон Республики Казахстан № 401-IV от 28 января 2011 года «О медиации», https://online.zakon.kz/Document/ ?doc_id=30927376\#pos=298;5.

Кодекс Республики Казахстан «О браке (супружестве) и семье» № 518-IV от 26 Аекабря 2011 года (по состоянию на 1 апреля 2019 года), https://online.zakon.kz/document/ ?doc_id=31102748.

Семейный кодекс Туркменистана от № 258-IV от 10 января 2012 года (по состоянию на 1 декабря 2018 года), http:// base.spinform.ru/show_doc.fwx?rgn=50609. 
Уголовный кодекс Республики Казахстан № 226-V от 3 июля 2014 года (по состоянию на 1 августа 2019 года), https:// online.zakon.kz/document/?doc_id=31575252.

Уголовно-процессуацьный кодекс Республики Казахстан № 231-V от 4 июця 2014 года (по состоянию на 1 апреця 2019 года), https://online.zakon.kz/document/?doc_id= 31575852.

ГражАанский процессуальный кодекс Республики Казахстан № 377-V ЗРК от 31 октября 2015 года (по состоянию на 22 июля 2019 года), https://zakon.uchet.kz/rus/ docs/K1500000377.

ГражАанский процессуальный кодекс Кыргызской Республики № 14 от 25 января 2017 года (по состоянию на 17 мая 2018 года), http://base.spinform.ru/show_doc. fwx?rgndoc.fwx?rgn=94089.

Кодекс Республики Казахстан «О налогах и других обязательных платежах в бюджет» (Налоговый кодекс) № 120-VI ЗРК от 25 декабря 2017 года (по состоянию на 1 августа 2019 года), https://online.zakon.kz/document/?doc_ id $=36148637 \#$ pos $=5 ;-34$.

ГражАанский процессуальный кодекс Республики Узбекистан № 3РУ-460 от 22 января 2018 года (по состоянию на 10 мая 2019 года), http://lex.uz/docs/3517334.

Временное положение «О судах аксакалов Кыргызской Республики», утверждено Указом Президента Кыргызской Респубцики № УП-30 от 25 января 1995 года (утратиц сику в соответствии с Указом Президента КР № УП-139 от 7 июня 2013 года), http://cbd.minjust.gov. $\mathrm{kg} / \mathrm{act} / \mathrm{view} / \mathrm{ru}-\mathrm{ru} / 46732$.

Регламент постоянно Аействующего Третейского суАа при центре изучения правовых проблем, утвержАен Решением Общего собрания комлектива Центра изучения правовых проблем от 10 января 2007 года, https:// 
nrm.uz/contentf?doc=360590_reglament_postoyanno _deystvuyushchego_treteyskogo_suda_pri_centre_ izucheniya_pravovyh_problem_(utverjden_resheniem_ obshchego_sobraniya_kollektiva_centra_izucheniya_ pravovyh_problem_ot_10_01_2007_g_(protokol_n_2)).

\section{Literatura}

Асанов Б., Верховный суд не согласен с мнением, что граждане не доверяют системе, https://rus.azattyk.org/a/ kyrgyzstan_court_rating/29501608.html.

Bodio T., Mołdawa T., Konstytucje państw Azji Centralnej: tradycje i wspótczesność, Warszawa 2007.

Bodio T., Uktady klanowe jako mechanizm polityki (na przykładzie państw Azji Centralnej), [w:] Transformacja społeczeństwa $i$ wtadzy w postradzieckiej Azji Centralnej: studia i rozprawy, red. T. Bodio, W. Jakubowski, A. Wierzbicki, Pułtusk 2008.

Борисов Н., Институт президентства в странах Центральной Азии: персонализачия vs. институционализация, „Центрахьная Азия и Кавказ” 2011, t. 14, https:// cyberleninka.ru/article/n/institut-prezidentstva-v-stranahtsentralnoy-azii-personalizatsiya-vs-institutsionalizatsiya.

Аинара А., Роль судов аксакалов в местном сообществе Кьргызской Республики, https://www.academia.edu/1802 7456/Статья_Аля_конференции_в_Н.

Грозин А., Элить Туркменистана и центральноазиатские кланы: обиее, особенное и трудности модернизаuиu, http://www.perspektivy.info/table/elity_turkmenistana_ i_centralnoaziatskije_klany_obshheje_osobennoje_i_ trudnosti_modernizacii_2010-12-21.htm.

Jones P., Islam, Society, and Politics in Central Asia, Pittsburgh 2017.

Киняпина Н.С., Центральная Азия во внутренней политике России во второй половине ХІХ века, [в:] История 
России ХIX-начала XX века, red.. В.А. Федоров, Москва 2004.

Корнеев В.В., Шариатские суды в Туркестане, http://www. ng.ru/ng_religii/2001-02-14/8_court.html.

Lenta.ru, В Киргизии в суды аксакалов пустят женщин, https://lenta.ru/news/2009/04/24/women/.

Leszczenko L., Instytucja ombudsmana w państwach poradzieckich: geneza - status prawny - rozwój, Warszawa 2011. Аогинов А.В., Адат и шариат в регионах Кавказа и Центральной Азии в постсоветский период, „Современный мусульманский мир” 2018, nr 3, https://islamjournal. ru/2018/id41/.

Massansalvador F.S., The Process of Nation Building in Central Asia and its Relationship to Russia's Regional Influence, Miami 2010, http://aei.pitt.edu/29783/1/SerraNa tionbldgCentAsiaLongJune10.pdf.

Мустафин С., Современная «инквизиция» или линчевание nо - Памирски?, http://www.ca-portal.ru/article:35012.

Официальный сайт Центра изучения правовых проблем Республики Узбекистан, Третейский суд при Центре изучения правовых проблем, http://www.lprc.uz/tre teyskiy.html. Сулейменов А., Аксакал: вчера, сегодня, завтра, https://ehistory.kz/ru/publications/view/2726.

ШаАыбеков К.Б., Аечентрализованные фоормы осуществления правосудия в контексте развития институтов судов аксакалов Кьргызстана, „Юридическая наука” 2019, nr 2, https://cyberleninka.ru/article/n/detsentralizo vannye-formy-osuschestvle niya-pravosudiya-v-konteksterazvitiya-institutov-sudov-aksakalov-kyrgyzstana.

Szukalski J., System konstytucyjny Kirgistanu, Warszawa 2018. Тороев Ж., Суды аксакалов в Кьргыззтане, „Юрист” 2005, № 1, https://journal.zakon.kz/203709-sudy-aksakalov-vkyrgyzstane.html. 
Тюцьканов С.А., Геворкова К.В., Законодательные основы применения медиации в странах СНГ и ближнего зарубежквя, http://lexandbusiness.ru/view-article.php?id= 6917 . Турсунбаева Н.С., Аеятельность судов аксакалов в Кьргызской Республике, „Вестник КРСУ” 2015, t. 2, nr 2, https://www.krsu.edu.kg/vestnik/2016/v6/a12.pdf.

Wierzbicki A., Załęski P., Trybalizm a władza w Azji Centralnej, Pułtusk 2008.

Wolters A., The State and Islam in Central Asia: Administering the Religious Threat or Engaging Muslim Communities?, Gőttingen 2014, https://www.econstor.eu/handle/10419 /102032.

Załęski P., Kultura polityczna więzi w Azji Centralnej (przypadek Kirgistanu na tle państw regionu), Warszawa 2011.

\section{Abstrakt}

Przedmiotem artykułu jest sądownictwo polubowne w państwach Azji Centralnej obejmującej: Kazachstan, Uzbekistan, Turkmenistan, Tadżykistan i Kirgistan. Uwarunkowania polityczne, mentalne i religijne sprawiły, że polubowne załatwianie sporów cieszy się tam dużą popularnością i uznaniem. Sądy polubowne funkcjonują w Uzbekistanie, Tadżykistanie i Kirgistanie, co zostało zagwarantowane na poziomie ustawowym, a w Kirgistanie nawet na poziomie konstytucyjnym.

Sądy polubowne rozpoznają sprawy z zakresu prawa cywilnego i gospodarczego, a ich wyroki mają moc jak wyrok sądu państwowego. Ponadto w Kirgistanie istnieją sądy aksakałów, czyli sądy mędrców, działające na zasadach organizacji społecznych. Rozpatrują one głównie sprawy majątkowe i rodzinne, kierując się nie tylko przepisami aktów prawnych, lecz również własnym sumieniem, przekonaniami, normami moralnymi i obyczajowymi oraz wskazaniami Koranu. Natomiast w Kazachstanie i Turkmenistanie, chociaż nie ma możliwości tworzenia sądów polubownych, to w tamtejszym ustawodawstwie jest szereg przepisów, które przewidują możliwość polubownego załatwiania sporów.

W konstatacji wskazano, że alternatywne formy załatwiania sporów, mające umocowanie w krajowym porządku prawnym, będą w pań- 
stwach Azji Centralnej utrzymane, ponieważ umożliwiają one szybkie i ugodowe załatwianie spraw cywilnych. Uzasadnione zastrzeżenia budzi jednak brak ustawowego wymogu posiadania stosownych kwalifikacji przez arbitrów sądów polubownych i członków sądów aksakałów, za wyjątkiem przewodniczących tych sądów.

Słowa kluczowe: Azja Centralna, konstytucja, ustawa, sąd polubowny, sąd aksakałów, wykonanie orzeczeń

\begin{abstract}
The subject of the article is the arbitration court in Central Asian countries including: Kazakhstan, Uzbekistan, Turkmenistan, Tajikistan and Kyrgyzstan. Political, mental and religious conditions have made amicable dispute resolution popular and widely used. Arbitration courts operate in Uzbekistan, Tajikistan and Kyrgyzstan, which was guaranteed at the statutory level, and in Kyrgyzstan even at the constitutional level.

Arbitration courts deal with cases in the field of civil and commercial law, and their judgements have the force of a state court judgement. In addition, in Kyrgyzstan there are aksakals courts, or courts of wise men or sages, operating on the principles of social organizations. They mainly consider property and family matters, guided not only by legal provisions, but also by their own conscience, beliefs, convictions, moral norms and the Koran's instructions. Although in Kazakhstan and Turkmenistan there is no possibility of creating arbitration courts, there are a number of provisions in their legislation systems that allow the possibility of amicable settlement of disputes.

The conclusions indicated that alternative forms of settlement of disputes, based on the national legal order, would be maintained in Central Asian countries, because they enable quick and amicable settlement of civil matters. However, justified objections arise because of lack of a statutory requirement to have appropriate qualifications by arbitrators of arbitration courts and members of the aksakals courts, except for the presidents of these courts.
\end{abstract}

Keywords: Central Asia, constitution, statute, arbitral court, aksakals court, execution of a judgment 


\section{Natalia Ciszewska}

Uniwersytet Milkołaja Kopernika w Toruniu

ORCID ID: https://orcid.org/0000-0001-9655-2173

\section{Od Gułagu do globalizacji, czyli rzecz o ewolucji rosyjskojęzycznej przestępczości zorganizowanej}

\section{Wstęp}

Państwa przechodzące transformację polityczną obejmującą zarówno zmiany społeczne, jak i prawne doświadczają zwykle niewielkiego, choć nieznaczącego wzrostu przestępczości. Zjawisko to może przybierać zasadniczo dwie formy: po pierwsze, mogą być to czyny niezgodne z prawem popełnione przez izolowane osoby lub małe grupy osób działających w sposób niesystematyczny lub mogą być to przestępstwa popełnione przez zorganizowane grupy przestępcze. W przypadku państw będących następcami byłego Związku Radzieckiego kryminolodzy, politolodzy i socjologowie jednogłośnie zgadzają się, że przestępczość zorganizowana jest głównym, a być może najważniejszym, czynnikiem hamującym rozwój gospodarczy, polityczny i społeczny państw poradzieckich. Działania przestępczości zorganizowanej mają reperkusje, które są odczuwalne daleko poza granicami byłego bloku wschodniego. Z powodu globalizacji sytuacja przestępczości we współczesnej Rosji i jej krajach sąsiadujących ma wpływ na jakość życia i bezpieczeństwo obywateli na całym świecie. Można powołać się w tym miejscu na zagrożenia związane z nielegalnym handlem materiałami jądrowymi i narkotykami, a także handlem ludźmi 
i innymi rodzajami przestępstw, której, obejmują swoim zasięgiem zarówno Wschód, jak i Zachód. Aby w pełni zrozumieć zaistniałe zjawisko należy przyjrzeć się jego początkom. Korzeni i przyczyn rozwoju przestępczości zorganizowanej w Rosji należy szukać w historii tego kraju, co słusznie zauważyła Katarzyna Laskowska: „jako zjawisko społeczne zrodziła się ona w XX w., lecz jej źródła sięgają wstecz nawet kilka wieków"1. Można postawić tezę, iż w Rosji istnieje swoista tradycja przestępczości, która przeniknęła wszystkie poziomy społeczeństwa i jest podstawą nowoczesnej przestępczości zorganizowanej w tym państwie. Jednakże współczesna, wielopoziomowa przestępczość zorganizowana nie istniała w przedrewolucyjnej Rosji, dlatego też w dalszej części artykułu przedstawiono ewolucję, jaką przeszła, począwszy od wczesnych epok sowieckich przez czasy postradzieckie, aż do chwili obecnej, aby wykazać zinstytucjonalizowany charakter tego rodzaju przestępczości oraz jej związki z polityką i biznesem, które nie ograniczają się tylko do terytorium Federacji Rosyjskiej.

\section{Geneza i ewolucja rosyjskojęzycznej przestępczości zorganizowanej}

Szukając początków przestępczości zorganizowanej w Rosji należy cofnąć się do czasów Rosji carskiej, kiedy to istniały małe, wiejskie grupy przestępców działających w zorganizowany sposób, kradnących np. konie lub inne wartościowe przedmioty. Grupy te odzwierciedlały strukturę komunalnych społeczności chłopskich. Po rewolucji z 1917 r. wiejskie grupy przestępców trafiły do miast i tam utworzyły kryminalne podziemie, które stało się źródłem współczesnej formy rosyjskiej przestępczo-

K. Laskowska, Ewolucja przestępczości zorganizowanej w Rosji, „Miscellanea Historico-Iuridica" 2008, t. 6, s. 55-65. 
ści zorganizowanej ${ }^{2}$. Wszak należy zauważyć, iż przestępców z okresu porewolucyjnego nie charakteryzował jeszcze zbyt wysoki poziom planowania i organizacji. Ich zbrodnie często były wykorzystaniem nadarzającej się okazji, a członkowie poszczególnych grup specjalizowali się w określonych przestępstwach pospolitych, takich jak kradzież kieszonkowa, włamanie lub oszustwo ${ }^{3}$. Poza brakiem wyraźnej tożsamości, gangi te nie posiadały wystarczającego wyrafinowania i koordynacji, aby stanowić zagrożenie dla rosyjskiego społeczeństwa i państwa.

Miejskie gangi zaczęły rosnąć w siłę, a wraz z tym pojawiły się problemy, z którymi wcześniej państwo rosyjskie nie musiało się zmagać. Rosyjskie terytorium, ze względu na swoją rozległość, było bardzo trudne do kontrolowania. Na rozległych przestrzeniach tego kraju znajdowały się nie tylko różne klimaty i strefy czasowe, ale przede wszystkim odmienne grupy etniczne, języki czy kultury, które negatywnie wpłynęły na efektywność rosyjskich władz w zakresie egzekwowania prawa. Przestępcy mogli z łatwością podróżować po różnych jurysdykcjach, a ponieważ policja i sądownictwo były niedofinansowane, to nie dysponowały wystarczającymi zasobami materialnymi i ludzkimi. Ponadto policja wówczas zmagała się z takimi problemami, jak korupcja, niskie morale, słabe wyszkolenie, wysoki wskaźnik rotacji i niewielkie zaufanie społeczne 4 . Ponadto prawo karne w Rosji w latach 20. XX w. było nieco dwuznaczne. Urzędnicy sądowi i politycy wspólnie

2 Ibidem.

3 E. Grant, The Russian Mafia and organized crime: How can this global force be tamed?, https://www.opendemocracy.net/od-russia/euan-grant/ russian-mafia-and-organised-crime-how-can-this-global-force-be-tamed [dostęp: 5.04.2019].

4 T. Gallati, From gulags to globalization: the birth of organized crime in stalinist Russia, s. 3, https://www.academia.edu/9469762/From_Gulags_to_ Globalization_The_Birth_of_Organized_Crime_in_Stalinist_Russia [dostęp: 7.05.2019], [za:] M. Galeotti. The World of the Lower Depths: Crime and Punishment in Russian History, s. 102. 
dokonywali przeglądu aktów prawnych i regularnie zmieniali przepisy prawa karnego, nigdy nie zgadzając się co do tego, co należy uważać za zachowania wyjęte spod prawa.

Jednakże oprócz gangów miejskich zaczęto wówczas dostrzegać także bardziej zorganizowane grupy przestępców, znanych jako vorovskoi mir, tworzących egalitarne bractwa (bratva), które żyły własnym, odrębnym i bardzo surowym prawem, zgodnie z którym największe przestępcze autorytety nazywano „worami w zakonie” lub tzw. „koronowanymi”. Właśnie z tego okresu pochodzą podstawowe zasady działalności „koronowanych”, które są aktualne do dziś. Między innymi określały one, że „wor w zakonie” zajmuje szczególne miejsce w hierarchii liderów świata przestępczego w Rosji. „Koronowany" musiał być zawodowym przestępcą, wyniesionym do godności „koronowanego" przez zgromadzenie „worów” w nagrodę za przywiązanie do zasad i trwanie w tradycji utrwalonej przez złodziejski świat ${ }^{6}$. To „koronowani” określali żywotność tradycji świata przestępczego. Niezależnie od miejsca pobytu utrzymywali stałe więzi między sobą, periodycznie spotykając się na złodziejskich zjazdach, tzw. „schodkach”. Podczas nich rozwiązywali wewnętrzne problemy świata złodziejskiego, dotyczące podziału terytorium i przestępczej działalności oraz czystości złodziejskich obyczajów ${ }^{7}$ „Worowski zakon” rządził się swoimi prawami, których podstawowym założeniem było bezwzględne ograniczenie współpracy z państwem. Zakaz ten wynikał z rewolucji bolszewickiej, kiedy wrogowie państwa próbowali stworzyć opozycję rekrutując do niej zawodowych przestępców. Aby wzmocnić antyrządową filozofię worom zakazano im także służby w wojsku, podejmowania

5 K. Laskowska, op.cit.

6 M. Galeotti, The Russian 'Mafiya': Consolidation and Globalisation, „Global Crime” 2004, nr 1, s. 55.

7 Ibidem. 
broni w obronie państwa, angażowania się w sprawy polityczne czy prace w organizacjach społecznych. Oczekiwano także, że porzucą swoje rodziny i skupią się na generowaniu zysków pochodzących wyłącznie z działalności przestępczej, a także będą zawsze w stanie wymierzyć lub zaakceptować każdą karę ustaloną przez ich kolegów złodziei. Jak pisze Tiffany Gallati, po wstąpieniu w szeregi worów, członkom nadawano nowe imię i nową tożsamość odpowiadającą ich nowemu sposobowi życia ${ }^{8}$. Chociaż ta armia złodziei była odpowiedzialna za większość zbrodni w Związku Radzieckim, to dopiero po ekspansji systemu obozów pracy Stalina w latach 20. i 30. XX w. stała się siłą, z którą trzeba było się liczyć.

System Gułagów nie izolował ani nie zwalczał worowskości. W rzeczywistości charakter systemu obozowego sprzyjał jej rozwojowi, pozwalając worom wchodzić w interakcje z różnymi więźniami, nawiązywać nowe kontakty, sprawdzać starych i rozpowszechniać swoją ideologię w różnych obozach w całym Związku Radzieckim poprzez transfery wewnątrz systemu. W 1952 r. w Gułagach przetrzymywano ponad 18 mln osób, jednakże więźniowie nie przebywali w jednym obozie przez cały wyrok ${ }^{9}$ W latach 1934-1947 około 3 mln więźniów zostało przeniesionych $\mathrm{w}$ ramach wewnętrznych transferów, co umożliwiło worom rozprzestrzenienie się po całej Rosji ${ }^{10}$. System Gułag zamiast udaremniać przestępcze zachowanie, stał się kluczowym czynnikiem jego ekspansji i wpływów.

Jak podaje Katarzyna Laskowska, po II wojnie światowej ak-

8 T. Gallati, From Gulags To Globalization The Birth of Organized Crime in Stalinist Russia, https://www.academia.edu/9469762/From_Gulags_to_Globalization_The_Birth_of_Organized_Crime_in_Stalinist_Russia [dostęp: 5.04.2019].

9 F. Varese, The Society of the Vor-V-Zakone, 1930s-1950s, https:// federicovarese.com/2019/08/01/the-society-of-the-vory-v-zakone-1930s1950s-2/ [dostęp: 5.04.2019].

10 Ibidem. 
tywność przestępcza pierwszej i drugiej kategorii kryminalistów w znacznym stopniu przyczyniła się do wybuchu bandytyzmu w kraju, który opanowano dzięki restrykcyjnemu systemowi prawa oraz sile organów ścigania i wymiaru sprawiedliwości ${ }^{11}$. W okresie istnienia stalinowskiego totalitarnego państwa wszak nie mogły funkcjonować żadne organizacje przestępcze. System represji skutecznie przyczynił się do destabilizacji świata przestępczego.

Na funkcjonowanie świata przestępczego miały też wpływ reformy podjęte w latach chruszczowskiej „odwilży”. W ich wyniku nastąpiły bowiem poważne zmiany w rosyjskiej polityce karnej. Polegały one na jej liberalizacji, ale nie wynikały z realnej oceny sytuacji przestępczej w kraju. Na podstawie przedwczesnych i bezpodstawnych twierdzeń o znacznym spadku przestępczości w państwie, a szczególnie o likwidacji jej zorganizowanych form, niemalże zaniechano z nią walki. W wyniku tego przestępcy poczuli się bezkarni, co poskutkowało szybkim odrodzeniem się przestępczości pospolitej, choć w innym wymiarze niż wcześniej. Bowiem utworzył się specyficzny świat przestępczy, w którym pojawili się liderzy, organizatorzy, autorytety przestępcze. Propagowali oni i upowszechniali „złodziejskie prawo" wywodzące się z worowskiego półświatka. Związek Radziecki wkroczył w erę, w której istniała niewyraźna granica między rządem a kryminalnym podziemiem. Występował wysoki poziom tolerancji dla działań ponad prawem, w wyniku czego przestępczość zorganizowana stała się nieodłącznym elementem klimatu politycznego i gospodarczego. Rosnący niedobór żywności, spowodowany gospodarką centralnie sterowaną, doprowadził do epidemii kradzieży i przekupstwa w celu przetrwania. Pojawienie się szarej strefy, której wartość stanowiła mniej więcej połowę ówczesnej radzieckiej gospodarki, stanowi-

11 K. Laskowska, op.cit. 
ło podłoże do rozkwitu nowej sowieckiej mafii. Wyhamowująca gospodarka późnych lat 50. i okrzepnięcie nowej klasy zorganizowanych przestępców stworzyło społeczeństwo z systemem moralności, który był zdeterminowany w dużej mierze przez sytuację, w której się znaleźli. Czynniki społeczno-ekonomiczne miały wyraźne implikacje polityczne: przestępczość zorganizowana stała się jedną ze spraw państwowych, jako element działający na wszystkich szczeblach władzy ${ }^{12}$.

Współpraca między przestępczością zorganizowaną a państwem znacznie wzrosła po śmierci Stalina, kiedy to członkowie partii komunistycznej zaczęli przyjmować łapówki od przedsiębiorstw działających w szarej strefie, w zamian za ochronę przed kontrolą instytucji i organów państwa. W tym samym czasie rosyjska mafia zapewniała również tym samym firmom ochronę przed innymi przestępcami w zamian za haracz ${ }^{13}$. Przestępcy i państwo pracowali razem, aby zapewnić ochronę biznesmenom działającym na czarnym rynku, przy czym państwo zapewniało ochronę z góry, a mafia $\mathrm{z}$ dołu. Władze ZSRR nie zwracały uwagi na rosnący poziom korupcji w partii komunistycznej. Z kolei rozkwit szarej strefy był akceptowalny, jako sposób na ominięcie barier narzuconych przez gospodarkę centralnie sterowaną, by zapewnić ludności dostęp do rzadkich towarów i usług ${ }^{14}$.

12 J.O. Finckenauer, Y.A. Voronin, The Threat of Russian Organized Crime, U.S. Department of Justice, Office of Justice Programs, 2001, s. 5, https://www.ncjrs.gov/pdffiles1/nij/187085.pdf [dostęp: 7.05.2019].

13 V. Sokolov, From Guns to Briefcases: The Evolution of Russian Organized Crime, „World Policy Journal” 2004, nr 1, s. 69, http://individual. utoronto.ca/seva/gunstobriefcases.pdf [dostęp: 7.05.2019].

14 Ibidem. 


\section{Współczesna rosyjskojęzyczna przestępczość zorganizowana}

Gdy aparat państwa i kryminalne podziemie stały się ściśle związane ze sobą, rosyjska mafia zaczęła przekształcać się w swoją współczesną formę, przyjmując postać spójnej trójwarstwowej struktury, na której szczycie znajdowali się członkowie partii komunistycznej wysokiego szczebla i rządowi biurokraci; bezpośrednio pod nimi byli ludzie zaangażowani $\mathrm{w}$ funkcjonowanie szarej strefy; $\mathrm{z}$ kolei najniższy szczebel tworzyli zawodowi przestępcy, którzy czerpali zyski z obrotu narkotykami, prostytucji lub organizowania gier hazardowych. Co ważne, nie tylko przedstawiciele wymiaru władzy czy urzędnicy stawali się przestępcami, również kryminaliści zaczęli zajmować wyższe stanowiska państwowe, co scharakteryzował Stephen Handelman w swoim studium Comrade Criminal ${ }^{15}$.

Konsekwencją przejścia od gospodarki centralnie planowanej do systemu wolnego rynku, były nowe możliwości, z których skorzystała nowa klasa rosyjskich przestępców zorganizowanych. Niektórzy gangsterzy w nielegalny sposób przedostali się na wschodzące rynki pieniężne, branże bankowe czy giełdy. Przykładem takiego działania może być przedsiębiorstwa Uralmash. W zapisach Białej Księgi Departamentu Sprawiedliwości USA, w odniesieniu do zagrożenia rosyjskojęzyczną przestępczością zorganizowaną, zauważono, że Uralmash, czyli jeden z najpotężniejszych i najbardziej niebezpiecznych syndykatów kryminalnych, które pojawiły się w rosyjskiej szarej strefie, kontroluje około 140 przedsiębiorstw komercyjnych, w tym banków i jest mocno zaangażowany w eksport

15 J. Handelman, Comrade criminal: the theft of the second Russian revolution, Londyn 1994, s. 59. 
surowców, broni, metali szlachetnych i materiałów radioaktywnych ${ }^{16}$. Wpis do Białej Księgi wskazuje, że rosyjskojęzyczna przestępczość zorganizowana swoim zasięgiem obejmuje nie tylko państwa byłego ZSRR. Przykładem może być fakt, iż grupa Uralmash jest znana z posiadania rozległej sieci kontaktów na całym świecie, w tym w Chinach, Niemczech i Stanach Zjednoczonych. Ponadto o wysokim poziomie zaawansowania tego przykładu struktur przestępczych świadczy ich standard organizacji, który przypomina bardziej korporację międzynarodową niż tradycyjną mafię. Wszystko to skutkuje dużymi trudnościami w rozpracowywaniu takich grup przestępczych oraz przypisani im winy za popełnione czyny.

Lata 90. w postradzieckiej Rosji doprowadziły do powstania sojuszy między moskiewskimi grupami przestępczymi a innymi grupami regionalnymi, m.in. w celu pozyskania byłych przedsiębiorstw państwowych poprzez prywatyzację. Mimo zdobycia pokaźnych majątków, wpływów i koneksji, przemoc stanowiła podstawę działań rosyjskich zorganizowanych grup przestępczych. Były one mocno uzbrojone, a zabójstwa kontraktowe stały się coraz bardziej problematyczne dla funkcjonariuszy organów ścigania ${ }^{17}$. Rozprzestrzenianie się grup przestępczych w całej Rosji doprowadziło do morderstw terytorialnych, bombardowań, porwań i bitew z bronią, co wskazuje na bezwzględną walkę podziemia o kontrolę nad wciąż kształtującą się gospodarką. W przeciwieństwie do innych grup przestępczych na świecie, rosyjscy gangsterzy postrzegają dziennikarzy (zwłaszcza tych, którzy przedstawiają ich w niekorzystnym świetle), jako uzasadnione cele, podważając tym samym wolność prasy. Jest to zupełnie inne podejście do

16 J.O. Finckenauer, Y.A. Voronin, op.cit.

17 S. Cheloukhine, The roots of Russian organized crime: from old-fashioned professionals to the organized cr iminal groups of today, https://link. springer.com/article/10.1007/s10611-008-9117-5 [dostęp: 5.04.2019]. 
przedstawicieli prasy, którzy w innych państwach np. we Włoszech czy w Stanach Zjednoczonych, byli zazwyczaj korumpowani lub zastraszani, w celu zmuszenia ich do publikowania pod dyktando mafii bądź też zaprzestania pisania na ten temat w ogóle. Bardzo rzadko zdarzały się tam brutalne zabójstwa dziennikarzy, co świadczy o większej brutalności rosyjskojęzycznych grup przestępczych.

W coraz bardziej kryminalistyczno-syndykalistycznym środowisku współczesnej Rosji, stereotypowy wizerunek gangstera stał się przestarzały. Obecnie większość podmiotów uwikłanych w system przestępczości zorganizowanej dobrze wtapia się w środowisko biznesowe i jest znacznie trudniejsza do zidentyfikowania niż niegdysiejsi bossowie. Wynika to po części ze struktury rosyjskiego rządu. We współczesnej Rosji "państwo" nadal charakteryzuje się taką samą pionową strukturą władzy jak za czasów radzieckich ${ }^{18}$. Struktura ta służy zwiększeniu korupcji, dlatego przestępczość zorganizowania nie jest tylko zewnętrznym zagrożeniem, ale jest raczej integralną częścią państwa. Członkowie rosyjskich grup przestępczych to nie tylko opływający w luksusy magnaci, bowiem współczesna przestępczość w tym Rosji jest tak różnorodna, jak sama jej ludność, zawiera wiele warstw dobrobytu gospodarczego i środowisk kulturowych. Specyficzną cechą współczesnej przestępczości zorganizowanej w Rosji jest to, że grupy przestępcze koncentrują się i działają wokół dużych miast i ośrodków przemysłowych. Co ważne, to właśnie moskiewskie zorganizowane grupy przestępcze dyktują politykę kryminalną pozostałym strukturom regionalnym.

18 K. Jasiecki, Korupcja na wysokich szczeblach władzy jako wyróżnik transformacji ustrojowej w Polsce, http://www.batory.org.pl/ftp/program/przeciw-korupcji/publikacje/inne_publikacje/jasiecki.pdf [dostęp: 5.04.2019]. 


\section{Ekspansja międzynarodowa rosyjskojęzycznej przestępczości zorganizowanej}

Współczesne rosyjskojęzyczne zorganizowane grupy przestępcze są zjawiskiem globalnym, gdyż działają w około 70 krajach $^{19}$. Oczywistym jest, że rosyjska mafia nie jest już tylko problemem rosyjskim. Biorąc pod uwagę najnowsze trendy i wydarzenia, można z niemalże pewnością wywnioskować, że niektóre organizacje przestępcze dokonały maksymalnego wykorzystania możliwości globalizującego się świata, a rosyjskojęzyczne grupy przestępcze są liderem w tej kwestii.

W ciągu trzech dekad od upadku Związku Radzieckiego świat stał się celem rosnącego zagrożenia ze strony organizacji przestępczych i działalności przestępczej, które wylały się poza granice Rosji i innych byłych republik radzieckich. Charakter i różnorodność popełnianych przestępstw wydają się nieograniczone - handel kobietami i dziećmi, narkotyki, handel bronią, kradzieże samochodów i pranie brudnych pieniędzy należą do tych najbardziej rozpowszechnionych. Przemyt jest szczególnie kłopotliwy dla Europy ze względu na bliskość geograficzną Rosji i Izraela (duża liczba rosyjskich imigrantów). Niestety żaden obszar świata nie wydaje się być pozbawiony wpływu rosyjskojęzycznych grup przestępczych. Pracownicy organów ścigania w Europie i poza nią szacują, że rosyjskojęzyczne grupy przestępcze mogą liczyć nawet do 300 tys. członków, co sprawia, że dominują w świecie przestępczym w wielu państwach na całym świecie $^{20}$. Pracownicy organów ścigania w wielu krajach - w tym w Hiszpanii, Grecji, na Węgrzech, we Włoszech, we

19 Roczny raport Interpolu 2017, https://www.interpol.int/content/ download/5258/file/Annual\%20Report\%202017-EN.pdf [dostęp: 5.04.2019].

20 Ibidem. 
Francji, w Meksyku czy w Stanach Zjednoczonych byli zaskoczeni odkryciem, iż to właśnie grupy przestępcze składające się z ludzi z byłego Związku Radzieckiego dominują obecnie w poszczególnych przestępczych półświatkach. Grupom mówiącym po rosyjsku udało się wyeliminować lokalne grupy i ustanowić własne strefy wpływów do tego stopnia, że nie muszą już wyjaśniać stosunków za pomocą broni ${ }^{21}$. Ponadnarodowy charakter rosyjskojęzycznej przestępczości zorganizowanej, w połączeniu z ich wysokim stopniem wyrafinowania i bezwzględności niewątpliwie przyciąga uwagę świata.

Według różnych badaczy ekspansja rosyjskojęzycznych grup rozpoczęła się w latach 70., kiedy Związek Radziecki i Stany Zjednoczone zgodziły się, że w zamian za ułatwienia handlowe ZSRR pozwoli Żydom na emigrację ${ }^{22}$. W latach 1971-1988 z 291 tys. Żydów wyemigrowało ze Związku Radzieckiego. Chociaż dokumenty podróży każdego imigranta wskazywały Izrael (165 tys.) lub Stany Zjednoczone (126 tys.) jako miejsce docelowe, to duża liczba z nich osiedliło się w Europie, a zwłaszcza w Niemczech ${ }^{23}$. Ponadto do 1988 r. około 56,5 tys. Ormian i 322 tys. etnicznych Niemców wyemigrowało ze Związku Radzieckiego ${ }^{24}$. Oczywistym jest, że wśród tych emigrantów byli ludzie ze wpisami do rejestrów sądowych, z wyrokami, które mogły być przyczynkiem do rozpoczęcia przestępczego życia za granicą. Po osiedleniu się w Europie większość radzieckich emigrantów musiała stawić czoła różnym problemom, takim jak bezrobocie. Niektórzy z nich próbowali rozwiązać swoje problemy finansowe poprzez nielegalne działania, takie jak: włamania,

21 Ibidem.

22 D. Rahmonova-Schwarz, Migrations during the Soviet Period and in the Early Years of USSR's Dissolution: A Focus on Central Asia, https:// journals.openedition.org/remi/5196 [dostęp: 11.04.2019].

23 Ibidem.

24 Ibidem. 
kradzieży, rabunku itp. Później niektórzy z nich zorganizowali się w grupy przestępcze, z których każda miała określone funkcje i stanowiska. W niektórych przypadkach grupom tym udało się nawiązać kontakty z rodzimym światem przestępczym.

Upadek Związku Radzieckiego na początku lat 90. XX w. doprowadził do gwałtownego wzrostu przestępczości zorganizowanej w byłych republikach radzieckich, z poziomem stale rosnącym do lat 2000-2002. W pierwszej połowie dekady rozwój przestępczości zorganizowanej w Rosji i innych państwach postsocjalistycznych miał głównie charakter konfrontacyjny, z różnego rodzaju kolizjami i konfliktami między grupami przestępczymi a władzami publicznymi. Okres ten charakteryzował się również dużą liczbą grup przestępczych o stale zmieniającej się liczbie członków. Do najczęstszych działań prowadzonych przez te grupy należały: wymuszanie pieniędzy (ściąganie haraczy) w zamian za tzw. ochronę, organizowanie prostytucji, przemyt narkotyków itp.

W drugiej połowie lat 90 . sytuacja uległa zmianie, gdyż można wówczas mówić o zbliżeniu się świata władzy i świata przestępczego. W ten sposób dochodziło do coraz większej liczby przypadków korupcji, a także zaangażowania się urzędników i funkcjonariuszy publicznych w nielegalne przedsięwzięcia. Z drugiej strony było kilka przypadków, w których przedstawiciele świata przestępczego zyskali władzę polityczną (np. Serghei Sasurin dwie kadencje w rosyjskiej Dumie); przywództwo gospodarcze (np. Anatolii Bicov) ${ }^{25}$. Ta eksplozja przestępczości na obszarze poradzieckim rozciągnęła się na inne kraje europejskie tak, że zgodnie z danymi niemieckiej policji na samym terytorium Niemiec istniało około 300 grup rosyjskojęzycznych wywodzących się różnych środowisk. W 1994 r. grupy

25 W. Kegö, A. Molcean, Russian Speaking Organized Crime Groups in the EU, http://isdp.eu/content/uploads/images/stories/isdp-main-pdf/2011_ kego-molcean_russian-speaking-organized-crime.pdf [dostęp: 11.04.2019]. 
te zajmowały się nielegalnym handlem skradzionymi samochodami, przemytem antyków i narkotyków, a także nielegalnym handlem metalami szlachetnymi, olejem i sztuką ${ }^{26}$. Niektórym grupom udało się osiągnąć znaczące zyski, nawiązując kontakty z rosyjskimi żołnierzami stacjonującymi w Niemczech, za pomocą których udało im się ukraść broń i amunicję, które miały być przetransportowane do Federacji Rosyjskiej ${ }^{27}$.

Analizując rozwój rosyjskojęzycznej przestępczości zorganizowanej w Europie w latach 90. należy wziąć pod uwagę, że grupy te można podzielić na różne kategorie według sposobu, w jaki się pojawiły. Dlatego też należy rozróżnić grupy przestępcze utworzone przez imigrantów wcześniej osiadłych w Europie i grupy, które pojawiły się w jednej z byłych republik radzieckich, a następnie przeniosły lub rozszerzyły swoją działalność na terytorium UE. Jednocześnie nie można pominąć faktu, że grupy przestępcze prowadzą część nielegalnej działalności w Europie, gdy krajem zamieszkania jest była republika radziecka. Rozróżnienia te są ważne, jeśli chodzi o metody i instrumenty zapobiegania i zwalczania rosyjskojęzycznej przestępczości zorganizowanej. W odniesieniu do drugiej kategorii należy podkreślić, że motywacja niektórych przestępców z Rosji i innych państw poradzieckich do przeniesienia ich „biznesu” do Europy zależy w każdym przypadku od kwestii takich, jak ustawodawstwo wewnętrzne kraju zamieszkania, polityka imigracyjna, rozwój turystyki itp. Niektórzy eksperci twierdzą, że w latach 1993-1995 do Europy przedostał się ogromny napływ imigrantów z byłych republik radzieckich, zwłaszcza z Rosjii ${ }^{28}$. Ta fala była głównie zdeterminowana przez konfrontacje, a właściwie

26 Ibidem.

27 Ibidem.

28 W. Kegö, A. Molcean, Russian Speaking Organized Crime Groups in the EU, [za:] L. Shelley, Contemporary Russian Organized Crime: Embedded in Russian Society", Organised Crime in Europe, s. 563. 
prawdziwe wojny wśród grup przestępczych w Rosji. Większość osób zaangażowanych w konflikty próbowała uciec do Europy, w szczególności do Europy Zachodniej, żeby być jak najdalej od Rosji. W ten sposób, w oparciu o różne okoliczności, warunki i motywy, w latach 90. w większości państw europejskich pojawiły się struktury przestępcze o głębokich korzeniach w byłym Związku Radzieckim. Dość interesującym faktem jest to, że rosyjskojęzycznym grupom zorganizowanym udało się nie tylko skutecznie osiedlić w Europie, ale także zainicjować współpracę z lokalnymi organizacjami przestępczymi. Przykładem takiej współpracy są stosunki nawiązane z włoską mafią. Rezultatem tej współpracy było pojawienie się „złodziei w prawie”, takich jak Robinzon Arabuli („Robinzon”) i Beslan Djonua („Besik”), którzy otworzyli pierwsze ekskluzywne sklepy w Moskwie z podrabianymi włoskimi markowymi ubraniami, butami i akcesoriami ${ }^{29}$. Według Olega Utitina, w jednym okresie w latach 90. istniał cały system kryminalny, dobrze zorganizowany na poziomie ponadnarodowym, który był zaangażowany w nielegalne działania nie tylko w Europie, ale i w Ameryce Północnej, a także w innych regionach świata ${ }^{30}$.

W raportach Europolu na temat przestępczości zorganizowanej z ostatnich lat rosyjskojęzyczne grupy przestępcze są coraz częściej wymieniane jako problem dotykający wszystkie państwa członkowskie UE, przy czym tego rodzaju grupy zajmują się praktycznie każdym rodzajem nielegalnej działalności ${ }^{31}$. Począwszy od 2008 r. urzędnicy w Brukseli zrozumieli, że rosyjskojęzyczna przestępczość zorganizowana wymaga indywidualnego podejścia i analizy. Konkluzje Rady Europejskiej

\footnotetext{
29 Ibidem.

30 Ibidem.

31 Raport Europolu, Organised Crime (SOCTA/OCTA), https://www. europol.europa.eu/activities-services/main-reports/european-union-serious-and-organised-crime-threat-assessment-2017 [dostęp: 11.04.2019].
} 
w sprawie sprawozdania z oceny zagrożenia przestępczością zorganizowaną w Rosji, zatwierdzone na 2863. posiedzeniu Rady ds. Wymiaru Sprawiedliwości i Spraw Wewnętrznych, stanowią dowód wypracowania nowego podejścia. Jednym z wniosków tego posiedzenia było poparcie idei opracowania oceny zagrożenia rosyjskojęzyczną przestępczością zorganizowaną, w której zlecono Europolowi opracowanie szablonu wywiadowczego zgodnie z metodologią raportu oceny zagrożenia przestępczością zorganizowaną (OCTA). Pomimo faktu, że w ostatnich latach wykryto i rozwiązano wiele grup przestępczych (składających się z ludzi z byłego Związku Radzieckiego) z różnych państw członkowskich UE (Hiszpania, Niemcy, Holandia, Francja i Szwajcaria), to rosyjskojęzyczne grupy przestępcze nadal zachowują swoją dominującą pozycję wśród innych narodowościowych struktur z przestępczego półświatka ${ }^{32}$. Co więcej, w krajach bałtyckich grupy te prawie zmonopolizowały ten obszar, utrzymując pod kontrolą całe centrum przestępcze na północnym wschodzie Europy. Granice między Federacją Rosyjską/państwami WNP a UE są ważnym czynnikiem, tworzącym pewną dynamikę niezbędną dla funkcjonowania tych grup przestępczych. Rosyjskojęzyczne grupy są zainteresowane wykorzystaniem banków zlokalizowanych w krajach skandynawskich i bałtyckich m.in. do prania pieniędzy pochodzących z przestępstw popełnianych w krajach WNP.

Jednym z kluczowych działań mających na celu zwalczanie rosyjskojęzycznej przestępczości zorganizowanej jest projekt Millennium, który pomaga poszczególnym państwom identyfikować osoby i firmy stojące za ponadnarodową euroazjatycką przestępczością zorganizowaną ${ }^{33}$. Eurazjatycka przestępczość

32 Ibidem.

33 Informacje $\mathrm{z}$ oficjalnej strony internetowej Interpolu, https:// www.interpol.int/Crimes/Organized-crime/Project-Millennium [dostęp: 11.04.2019]. 
zorganizowana, w której skład wchodzą rosyjskojęzyczne grupy zorganizowane, pochodzą w większości z Europy Wschodniej i Kaukazu. Ich działalność obejmuje różne obszary przestępcze a ich zasięgi docierają do niemalże całej Europy, Ameryki Północnej oraz na Bliski Wschód. Zespół projektowy Millennium opracowuje cykliczne oceny eurazjatyckiego krajobrazu przestępczości zorganizowanej w oparciu o informacje dostarczone przez krajowe biura centralne. Analizy Millennium zapewniają państwom uczestniczącym dane dotyczące wysoko postawionych członków rosyjskojęzycznych zorganizowanych grup przestępczych. Udostępnione informacje obejmują m.in. dane osobiste, biometrię, dane współpracowników, lokalizacje terenów działania i obszarów wpływów, osobiste znaki identyfikujące, np. tatuaże, atrybuty fizyczne, znaki szczególne. Worowie w zakonie - stojący na szczycie rosyjskojęzycznych grup przestępczych - zostali uznani przez uczestników projektu Millennium, jako priorytetowy obszar badań ${ }^{34}$. Honorowi złodzieje przestrzegają własnego kodeksu honorowego i etyki, który regulują zachowania przestępcze. Inwestują w akcje, nieruchomości i firmy, którymi zarządzają najbardziej wpływowi i wysoko postawieni worowie. Pieniądze te są inwestowane w legalne firmy, dlatego „złodzieje w prawie” często mają duży wpływ na działalność i kontrolę konkretnego sektora gospodarki w danym państwie. Oznacza to, że fundusze przestępcze są generowane i dystrybuowane za pośrednictwem legalnych i nielegalnych kanałów, co ma wpływ na globalną gospodarkę, a także na kondycję rynków poszczególnych krajów.

Projekt Millenium realizowany jest w oparciu o grupy robocze, które spotykają się regularnie, aby umożliwić funkcjonariuszom organów ścigania dzielenie się doświadczeniami, wymianę informacji wywiadowczych, identyfikację pojawiają-

34 Ibidem. 
cych się trendów i modus operandi eurazjatyckich grup przestępczych. Spotkania grupy roboczej zostały zorganizowane we Lwowie (maj 2018 r.), Moskwie (czerwiec 2017 r.), Tbilisi (wrzesień 2016 r.) i Pradze (luty 2015 r.) $)^{35}$.

\section{Konkluzje}

Podsumowując należy zaakcentować, iż wbrew ogólnym przekonaniom nie istnieje jednolita rosyjska mafia. Istnieje natomiast wiele rosyjskojęzycznych zorganizowanych grup przestępczych, których korzenie często sięgają dawnego ZSRR. Ta forma przestępczości zorganizowanej jest odmienna od mafii sycylijskiej - nie jest to ściśle zhierarchizowana organizacja oparta na rodzinie, stałym członkostwie i rytuałach indukcyjnych. Rosyjskojęzyczne grupy obejmują szeroki zakres podmiotów, które nie są powiązane więzami rodzinnymi i działają w oparciu o elastyczne struktury sieciowe. Nie można ich utożsamiać ze stereotypowym obrazem przestępców z podziemia, ale z przebiegłymi przestępcami, którzy często są powiązani z odnoszącymi sukcesy przedsiębiorcami lub wysokimi urzędnikami. Konkludując można wymienić kilka specyficznych cech rosyjskojęzycznych grup przestępczych:

- stabilność i zrównoważony rozwój;

- skłonność do osiągnięcia maksymalnego zysku;

- wysoki stopień organizacji nielegalnych działań;

- wyraźny podział funkcji i dobrze określona struktura hierarchiczna;

- istnienie wspólnych funduszy rezerwowych (obsahak);

- stałe próby legalizacji dochodu z działalności przestępczej. Wszystkie te funkcje pozwalają dojść do wniosku, że rosyjskojęzyczne grupy przestępcze powinny być uznane za szcze-

35 Ibidem. 
gólne niebezpieczne, których wpływy stale rosną na całym świecie.

\section{Bibliografia}

Cheloukhine S., The roots of Russian organized crime: from old-fashioned professionals to the organized cr iminal groups of today, https://link.springer.com/article/10.1007/ s10611-008-9117-5.

Finckenauer J.O., Voronin Y.A, The Threat of Russian Organized Crime, U.S. Department of Justice, Office of Justice Programs, 2001, s. 5, https://www.ncjrs.gov/pdffiles1/ nij/187085.pdf.

Grant E., The Russian Mafia and organized crime: How can this global force be tamed?, https://www.opendemocracy. net/od-russia/euan-grant/russian-mafia-and-organisedcrime-how-can-this-global-force-be-tamed.

Gallati T., From gulags to globalization: the birth of organized crime in stalinist Russia, https://www.academia. edu/9469762/From_Gulags_to_Globalization_The_Birth_ of_Organized_Crime_in_Stalinist_Russia.

Galeotti M., The World of the Lower Depths: Crime and Punishment in Russian History.

Galeotti M., The Russian 'Mafiya': Consolidation and Globalisation, „Global Crime” 2004.

Gallati T., From Gulags To Globalization The Birth of Organized Crime in Stalinist Russia, https://www.academia. edu/9469762/From_Gulags_to_Globalization_The_Birth_ of_Organized_Crime_in_Stalinist_Russia.

Handelman J., Comrade criminal: the theft of the second Russian revolution, Londyn 1994. 
Informacje z oficjalnej strony internetowej Interpolu, https:// www.interpol.int/Crimes/Organized-crime/Project-Millennium.

Jasiecki K., Korupcja na wysokich szczeblach władzy jako wyróżnik transformacji ustrojowej w Polsce, http://www.batory. org.pl/ftp/program/przeciw-korupcji/publikacje/inne_publikacje/jasiecki.pdf.

Kegö W., Molcean A., Russian Speaking Organized Crime Groups in the EU, http://isdp.eu/content/uploads/images/stories/isdp-main-pdf/2011_kego-molcean_russian-speaking-organized-crime.pdf.

Laskowska K., Ewolucja przestępczości zorganizowanej w Rosji, „Miscellanea Historico-Iuridica” 2008, t. 6.

Roczny raport Interpolu 2017, https://www.interpol.int/content/download/5258/file/Annual\%20Report\%202017-EN. pdf.

Rahmonova-Schwarz D., Migrations during the Soviet Period and in the Early Years of USSR's Dissolution: A Focus on Central Asia, https://journals.openedition.org/remi/5196.

Raport Europolu, Organised Crime (SOCTA/OCTA), https:// www.europol.europa.eu/activities-services/main-reports/ european-union-serious-and-organised-crime-threat-assessment-2017.

Sokolov V., From Guns to Briefcases: The Evolution of Russian Organized Crime, „World Policy Journal” 2004, nr 1, http:// individual.utoronto.ca/seva/gunstobriefcases.pdf.

Varese F., The Society of the Vor-V-Zakone, 1930s-1950s, https://federicovarese.com/2019/08/01/the-society-of-the-vory-v-zakone-1930s-1950s-2. 


\begin{abstract}
Abstrakt
Świat jest pełen przestępstw i bez względu na to, jakie działania zostaną podjęte, nie można ich całkowicie wyeliminować. Istnieją organizacje przestępcze, których zasięg i wpływy obejmują niemalże cały glob. Przykładem tego typu podmiotów są rosyjskojęzyczne zorganizowane grupy przestępcze, dobrze znane przez organy ścigania wielu państw. Aby zrozumieć jak te organizacje działają w obecnych czasach, należy zrozumieć jak powstały i jak dostosowały się przez lata. W tym artykule przeanalizowana została geneza powstania rosyjskojęzycznych zorganizowanych grup przestępczych, ich ewolucja w czasie oraz działania podjęte współcześnie przez Europol i Interpol w celu ich zwalczania. Autorka za cel niniejszego artykułu obrała sobie zobrazowanie i przedstawienie ogólnego zarysu rosyjskojęzycznej przestępczości zorganizowanej oraz wskazanie, że zatoczyła ona znacznie szersze kręgi niż może się wydawać.
\end{abstract}

Słowa kluczowe: przestępczość zorganizowana, Rosja, Europol, Interpol, globalizacja, mafia, gangi

\begin{abstract}
The world is full of crime and no matter what action is taken, it cannot be completely eliminated. There are criminal organizations whose reach and influence cover almost the entire globe. An example of this type of entity are Russian-language organized crime groups, well known by law enforcement agencies of many countries. To understand how these organizations work today, you need to understand how they arose and how they have adapted over the years. This article examines the genesis of the emergence of organized Russian-language organized crime groups, their evolution over time, and the actions taken today by Europol and Interpol to combat them. The author chose the purpose of this article to depict and present a general outline of Russian-language organized crime and to indicate that it has spread far wider than it may seem.
\end{abstract}

Keywords: organized crime, Russia, Europol, Interpol, globalization, mafia, gangs 


\section{Maria Golda-Sobczak}

Uniwersytet im. Adama Mickiewicza w Poznaniu

ORCID ID: https://orcid.org/0000-0002-3854-7007

\section{Prawo autorskie Federacji Rosyjskiej}

\section{Podstawy normatywne}

W myśl art. 44 ust. 1 Konstytucji Federacji Rosyjskiej każdemu gwarantuje się swobodę twórczości literackiej, plastycznej, naukowej, technicznej i innej, a także swobodę wykładania. Zadeklarowano także w tym przepisie, że własność intelektualna jest chroniona przez prawo, a w kolejnych ustępach przywołanego artykułu, że każdy ma prawo do udziału w życiu kulturalnym i korzystania z placówek kulturalnych oraz dostępu do wartości kulturalnych. Każdy także ma obowiązek troszczyć się o zachowanie spuścizny historycznej i kulturalnej, chronić zabytki historii i kultury. W treści art. 71 lit. m Konstytucji stwierdzono, że prawne regulowanie własności intelektualnej należy do kompetencji Federacji Rosyjskiej ${ }^{1}$. W ten sposób podmioty Federacji wskazane w treści art. 65 Konstytucji pozbawione zostały możliwości stanowienia aktów normatywnych, zawierających normy prawne, odnoszące się do prawa własności intelektualnej, w tym także do prawa autorskiego ${ }^{2}$. Warto w tym momencie zauważyć,

1 Konstytucja Federacji Rosyjskiej przyjęta w ogólnonarodowym referendum w dniu 12 grudnia $1993 \mathrm{r}$.

2 Państwa będące członkami Euroazjatyckiej Unii Gospodarczej (dalej: EAUG) w chwili jej powstania, jako państwa poradzieckie wywodzą swoje obowiązujące ustawodawstwo w dziedzinie prawa autorskiego z tradycji Związku Radzieckiego, która była punktem wyjścia do dalszego tworzenia prawa krajowego. Do chwili powstania EAUG każde z tych państw przeszło 
że w sprawach objętych zakresem działania Federacji Rosyjskiej, federalne ustawy konstytucyjne oraz ustawy federalne mają bezpośrednie zastosowanie na całym obszarze Federacji Rosyjskiej. Federalne ustawy konstytucyjne odnoszą się do najważniejszych spraw dotyczących praw i wolności obywateli oraz obowiązków państwa, które nie zostały uregulowane w Konstytucji Federacji Rosyjskiej ${ }^{3}$.

Należy pamiętać, że poważne zmiany w zakresie prawa ochrony własności intelektualnej w ogólności a prawa autorskiego w szczególności wiążą się z powstaniem Euroazjatyckiej Unii Gospodarczej, która rozpoczęła swoją działalność 1 stycznia 2015 r. jako organizacja umożliwiająca swobodny przepływ towarów i usług między państwami członkowskimi oraz wspierająca różne formy współpracy gospodarczej ${ }^{4}$. W polskiej literaturze naukowej nie zwraca się należytej uwagi na znaczenie rozdziału XXIII umowy akcesyjnej, zatytułowanego Wtasność intelektualna. W rozdziale tym wymieniono akty prawa międzynarodowego z dziedziny ochrony własności intelektualnej, do których implementacji i wykonywania zobowiązują się państwa członkowskie EAUG5

daleką i bardzo różną od siebie drogę kształtowania ustawodawstwa, orzecznictwa oraz polityki państwa w dziedzinie prawa autorskiego. Harmonizacja prawa oraz ujednolicenie polityki krajowej okazała się wyzwaniem dla nowego podmiotu prawa międzynarodowego, o czym może świadczyć liczba orzeczeń.

3 W literaturze wyodrębniano piętnaście tego typu spraw, jednak nie wyliczono wśród nich kwestii odnoszących się do prawa autorskiego. М.В. Бамгай, Конституционное право Российской Федерации, Москва 2007, s. 35.

4 Раздел XXIII «Интелмектуальная собственность», Аоговор о Евразийском экономическом союзе от 29 мая 2014 года.

5 Zaliczono do nich: konwencję berneńską o ochronie dzieł literackich i artystycznych z 9 września 1886 r. (w redakcji z 1971 r.) (Akt paryski konwencji berneńskiej o ochronie dzieł literackich i artystycznych, podpisany w Paryżu w dniu 24 lipca $1971 \mathrm{r}$. Polska ratyfikowała tekst tego dokumentu w 1990 r. - Dz.U. 1990, nr 82, poz. 474.); traktat budapeszteński o międzynarodowym uznawaniu depozytów mikroorganizmów dla celów procedury 


\section{Pamiętać należy, że częścią systemu prawnego Federa-}

patentowej z 28 kwietnia 1977 r. (Traktat budapesztański o międzynarodowym uznawaniu depozytu drobnoustrojów dla celów postępowania patentowego oraz Regulamin wykonawczy, podpisany w Budapeszcie w dniu 28 kwietnia 1977 r. Polska ratyfikowała ten dokument w 1994 r. - Dz.U. 1994, nr 110, poz. 528); Traktat o prawie autorskim Światowej Organizacji Własności Intelektualnej z 20 grudnia 1996 r. (Dz.U. 2005, nr 3, poz. 12); Traktat Światowej Organizacji Własności Intelektualnej o występach i fonogramach z 20 grudnia 1996 r. (Traktat Światowej Organizacji Własności Intelektualnej o artystycznych wykonaniach i fonogramach, podpisany w Genewie 20 grudnia 1996 r. Polska ratyfikowała ten dokument w 2004 r. - Dz.U. 2004, nr 41, poz. 375); Traktat o prawie patentowym z 1 czerwca 2000 r. (Traktat Światowej Organizacji Własności Intelektualnej o prawie patentowym, podpisany w Genewie 1 czerwca 2000 r. Dokument nie został ratyfikowany przez Polskę); Układ o współpracy patentowej z 19 czerwca 1970 r. (Układ o współpracy patentowej, podpisany w Waszyngtonie w dniu 19 czerwca 1970 r., poprawiony dnia 2 października 1979 r. i zmieniony dnia 3 lutego 1984 r. Polska ratyfikowała ten dokument w 1991 r. - Dz.U. 1991, nr 70, poz. 303); Konwencję o ochronie producentów fonogramów przed nielegalnym powielaniem ich fonogramów z 29 października 1971 r. (The Convention for the Protection of Producers of Phonograms Against Unauthorized Duplication of Their Phonograms, znana także jako Geneva Phonograms Convention, podpisana w Genewie w dniu 29 października $1971 \mathrm{r}$. Dokument nie został ratyfikowany przez Polskę); Porozumienie madryckie dotyczące międzynarodowej rejestracji znaków z 14 kwietnia 1891 r. (Porozumienie madryckie o międzynarodowej rejestracji znaków, podpisany w Madrycie w dniu 14źkwietnia 1891 r. Polska ratyfikowała ten dokument w 1993 r. - Dz.U. 1993, nr 116, poz. 514); Protokół dotyczący porozumienia madryckiego w sprawie międzynarodowej rejestracji znaków z 28 czerwca 1989 r. (Protokół do Porozumienia madryckiego o międzynarodowej rejestracji znaków, podpisany w Madrycie w dniu 27 czerwca 1989 r. Polska ratyfikowała ten dokument w 2003 r. - Dz.U. 2003, nr 13, poz. 129); Międzynarodową konwencję o ochronie praw wykonawców, producentów fonogramów i organizacji nadawczych z dnia 26 października 1961 r. (Międzynarodowa konwencja o ochronie wykonawców, producentów fonogramów oraz organizacji nadawczych, podpisana w Rzymie w dniu 26 października $1961 \mathrm{r}$. Polska ratyfikowała ten dokument w 1997 r. - Dz.U.1997, nr 125, poz. 800); Konwencję paryską o ochronie własności przemysłowej z 20 marca 1883 r. (Konwencja związkowa paryska o ochronie własności przemysłowej, podpisana w Paryżu w dniu 20 marca 1883 r. Polska ratyfikowała ten dokument w 1992 r. - Dz.U. 1922, nr 8, poz. 58); Traktat singapurski o prawie znaków towarowych z dnia 27 marca 2006 r. (Traktat singapurski o prawie znaków towarowych i regulamin do Traktatu singapurskiego o prawie znaków towarowych, podpisany w Singapurze w dniu 27 marca 2006 r. Polska ratyfikowała ten dokument w 2009 r. - Dz.U. 2009, nr 100, poz. 838). 
cji Rosyjskiej są w myśl art. 15 ust. 4 Konstytucji ogólnie uznane zasady i normy prawa międzynarodowego oraz umowy międzynarodowe zawarte przez Federację Rosyjską. Stanowią one część składową systemu prawnego Federacji. Wskazano przy tym, że jeżeli zawarta przez Federację Rosyjską umowa międzynarodowa stanowi inaczej niż przewiduje ustawa, stosuje się postanowienia umowy międzynarodowej. Przypomnieć w tej sytuacji wypada, że Federacja Rosyjska po upadku ZSRR 13 marca przystąpiła do konwencji berneńskiej ${ }^{6}$, ponadto związana jest także treścią Powszechnej konwencji o prawie autorskim, której b. ZSRR został członkiem w 1973 r.7 Jest także związana Traktatem WIPO, Porozumieniem TRIPS oraz Konwencją o rozpowszechnianiu sygnałów niosących programów przekazywane przez sputniki z 21 maja 1974 r. ${ }^{8}$ Z racji członkostwa we Wspólnocie Niepodległych Państw Federacja Rosyjska stała się stroną umów zawieranych przez państwa należące do tych organizacji, w tym m.in. Porozumienia o współpracy w obrębie prawa autorskiego i praw pokrewnych, zawartego w Moskwie 24 września 1993 r. ${ }^{9}$

6 Постановцение Правительства РФ от 03 ноября 1994 г. N 1224 О присоединении Российской Федерации к Бернской конвенции об охране митературных и художественных произведений в редакции 1971 г., Всемирной конвенции об авторском праве в редакции 1971 года и дополнительным Протоколам 1 и 2, Конвенции 1971 года об охране интересов производителей фонограмм от незаконного воспроизводства их фонограмм, „Собрание законодательства Российской Федерации” 1994, nr 29, s. 3046.

7 Указ Президиума Верховного Совета СССР от 21 февраля 1973 г. N 3959-VIII О внес нии изменений и дополнений в Основы гражАанского законодательства Союза ССР и союзных республик (фактически утратил сику), „ВеАомости Верховного Совета СССР” 1973, nr 9, s. 138.

8 Указ Президиума Верховного Совета СССР О присоединении Союза Советских Социалистических Республик к Конвенции о распространении несущих программы сигналов, передаваемых через спутники, „Ведомости Верховного Совета СССР” 24.08.1988, nr 34.

9 Соглашение стран СНГ от 24.09.1993 О сотрудничестве в области охраны авторского права и смежных прав, „Содружество. Информа- 
Nie ulega wątpliwości, że kwestii dotyczących własności intelektualnej i ustawodawstwa cywilnego dotyczy w pierwszym rzędzie Kodeks cywilny Federacji Rosyjskiej ${ }^{10}$. Problematyka prawa autorskiego została ujęta w części czwartej Kodeksu cywilnego, w której skodyfikowano prawo własności intelektualnej ${ }^{11}$. Normy te weszły w życie z dniem 1 stycznia $2008 \mathrm{r}$. Jednocześnie w tej dacie utraciły moc prawną dotychczasowe akty normatywne regulujące prawo autorskie ${ }^{12}$. Normy

ционный вестник Совета глав государств и Совета глав правительств СНГ” 1993, nr 4 (12), „Бюмметень межАународных договоров” 2008, nr 3.

10 Składa się on z czterech części, z których pierwsza to ustawa federalna z 30 listopada 1994 r. nr 51-F 3, zawiera przepisy ogólne, normy prawa rzeczowego oraz przepisy części ogólnej prawa zobowiązań. Część druga to ustawa federalna z 26 stycznia 1996 r., nr 14-F3, to przepisy dotyczące części szczególnej prawa zobowiązań. Część trzecia zawarta w ustawie federalnej z 26 listopada 2001 r., nr 146 - F3, obejmuje normy prawa spadkowego oraz prawa międzynarodowego prywatnego. Część czwarta, którą stanowi ustawa federalna z 18 grudnia 2006 r., nr 230-F3 obejmuje przepisy prawa własności intelektualnej i środków indywidualizacji. Ta ostatnia część była wielokrotnie nowelizowana, przy czym najgłębsze zmiany przyniosła ustawa federalna z dnia 12 marca 2014 r., nr 35-F3.

11 Кодекс Российской ФеАерации от 18.12.2006 № 230-Ф3 ГражАанский кодекс Российской Федерации. Часть четвертая, „Собрание законодательства Российской Федерации” 2006, nr 52, s. 5496 (cz. I); „Российская газета”, 22.12.2006, nr 289; „Парламентская газета”, 21.12.2006, nr 214-215; z późn. zm. [dalej: KC FR].

12 Pierwsza postradziecka ustawa o prawie autorskim i prawach pokrewnych w Federacji Rosyjskiej weszła w życie 3 sierpnia 1993 r. Zob. Закон РФ от 09.07.1993 N 5351-1 Об авторском праве и смежных правах, „Российская газета" 1993, nr 147. Całkowicie zastąpiła ona sowieckie prawo w dziedzinie praw autorskich, co nie miało miejsca wcześniej. Nowa ustawa o prawie autorskim z 1993 r. została oparta na modelu WIPO i była zgodna z europejską tradycją kontynentalną: wyraźnie dzieliła prawa ekonomiczne i moralne, w tym szczegółowe przepisy dotyczące praw pokrewnych. Ustawa o prawie autorskim z 1993 r. ustanowiła czas trwania praw autorskich majątkowych na 50 lat po śmierci autora lub 50 lat od opublikowania anonimowej pracy. Po wejściu w życie prawa przywrócono prawa autorskie i prawa pokrewne do dzieł stworzonych przez autorów radzieckich, w tym tych, dla których wygasły lub w ogóle nie były chronione. W 2004 r. prawo zostało zmienione. Zob. ФеАера^ьный закон от 20.07.2004 N 72-Ф3 О внесении изменений в Закон Российской Федерации Об авторском праве и смежных правах, „Российская газета” 2004, nr 159. W szczególności termin 
prawa autorskiego znalazły się w dziale VII części czwartej, w rozdziałach 69-77 ${ }^{13}$. Zwrócić w tym miejscu wypada uwagę na fakt, że uregulowano w przywołanych przepisach pojęcie twórcy działalności intelektualnej (art. 1228), kwestię praw wyłącznych (art. 1229), czas trwania praw wyłącznych (art. 1230), kwestię rejestracji rezultatu własności intelektualnej (art. 1232), rozporządzania prawem wyłącznym do takich rezultatów (art. 1233), umów o przeniesienie prawa wyłącznego i umów licencyjnych (art. 1234-1239), a także kwestie odnoszące się do organizacji zbiorowego zarządzania prawami autorskimi i prawami pokrewnymi (art. 1242-1244). W art. 1255 uregulowano treść praw autorskich przysługujących twórcy, a w dalszych przepisach pojęcie twórcy utworu (art. 1257), współautorstwo (art. 1258), przedmiot prawa autorskiego (art. 1259-1263), autorskie prawa osobiste (art. 1265-1268), prawa wyłączne do utworu (art. 1270), dozwolony użytek chronionych utworów (art. 1273-1279), kwestie umów prawa autor-

ochrony prawa autorskiego został przedłużony do 70 lat. W dniu 1 stycznia 2008 r., w wyniku kodyfikacji, weszła w życie czwarta księga Kodeksu cywilnego Federacji Rosyjskiej, która szczegółowo reguluje stosunki w dziedzinie praw autorskich i praw pokrewnych, a tym samym utraciła swoją moc prawną wcześniejsza ustawa O prawie autorskim i prawach pokrewnych. Zob. Федерахьный закон от 18.12.2006 N 231-Ф3 (реА. от 29.06.2015, с изм. от 30.12.2015) О ввеАении в Аействие части четвертой ГражАанского коАекса Российской ФеАерации (с изм. и Аоп., вступ. в сику с 01.07.2015), „Российская газета” 2006, nr 289.

13 W tej grupie rozdziałów najistotniejszy wydaje się rozdział $69 \mathrm{za}-$ wierający przepisy ogólne odnoszące się do całego prawa własności intelektualnej (art. 1225-1254) oraz rozdział 70 zatytułowany Prawa autorskie, obejmujący przepisy szczególne (art. 1255-1302). W dalszych rozdziałach znalazły się regulacje odnoszące się do praw pokrewnych (art. 1303-1344), prawa patentowego (art. 1345-1407), osiągnięć selekcyjnych (art. 1408-1447), topografii układów scalonych (art. 1448-1464), prawo do tajemnicy przedsiębiorstwa (know-how) (art. 1465-1472), środków indywidualizacji osób prawnych, towarów, prac, usług i przedsiębiorstw, praw do firmy, znaku towarowego, usługowego, oznaczenia miejsca pochodzenia towaru oraz oznaczenia handlowego (art. 1473-1541). W ostatnim 77 rozdziale (art. 1542-1551) zawarto normy szczególne odnoszące się do korzystania $\mathrm{z}$ rezultatów działalności intelektualnej w zestawieniu wspólnej technologii. 
skiego (art. 1285-1290), utworów pracowniczych (art. 1295), utworów powstałych na zamówienie (art. 1296-1298), wreszcie odpowiedzialności za naruszenie prawa wyłącznego do utworu (art. 1301).

Kodeks cywilny Federacji Rosyjskiej przyznaje wyłączne prawo do dzieł naukowych, literatury i sztuki, które zostały opublikowane na terytorium Federacji Rosyjskiej lub nie zostały opublikowane, ale które zostały ustalone na terytorium Federacji Rosyjskiej, a ich autorami lub ich następcami prawnymi są obywatele FR. Kodeks ma także zastosowanie wobec utworów opublikowanych poza terytorium Federacji Rosyjskiej lub niepublikowanych, lecz ustalonych poza terytorium Federacji Rosyjskiej, których autorami lub ich następcami prawnymi są obywatele Federacji Rosyjskiej. Ponadto przepisy Kodeksu obowiązują, zgodnie z postanowieniami umów międzynarodowych ratyfikowanych przez Federację Rosyjską, w przypadku utworów ogłoszonych poza terytorium Federacji Rosyjskiej lub niepublikowanych, lecz ustalonych poza terytorium Federacji Rosyjskiej, gdy autorami takich utworów lub ich następcami prawnymi są obywatele innych państw i bezpaństwowcy ${ }^{14}$. Przy udzielaniu ochrony utworom, zgodnie z umowami międzynarodowymi Federacji Rosyjskiej, okres wyłącznego prawa do tych utworów na terytorium Federacji Rosyjskiej nie może przekroczyć okresu obowiązywania wyłącznego prawa ustanowionego w kraju pochodzenia utworu. Utwór uważa się za opublikowany po raz pierwszy na terenie Federacji Rosyjskiej,

14 Ochrona utworów na terytorium Federacji Rosyjskiej, zgodnie z umowami międzynarodowymi Federacji Rosyjskiej, udzielana jest w odniesieniu do dzieł, wobec których nie wygasły prawa autorskie majątkowe ani w kraju pochodzenia utworu, ani zgodnie z postanowieniami KC FR. Udzielając ochrony utworowi na terytorium Federacji Rosyjskiej zgodnie z umowami międzynarodowymi, autor dzieła lub inny oryginalny posiadacz jest określany przez prawo państwa, na którego terytorium doszło do faktury prawnej, która służyła jako podstawa nabycia praw autorskich. 
jeżeli w ciągu trzydziestu dni po dacie pierwszej publikacji poza terytorium Federacji Rosyjskiej opublikowano ten utwór na terytorium Federacji Rosyjskiej.

Problematyki prawa autorskiego dotyczą także normy ustaw federalnych:

- z dnia 27 grudnia 1991 r., nr 2124-1 o środkach masowego przekazu ${ }^{15}$;

- z dnia 9 października 1992 r., nr 3612-1 o podstawach ustawodawstwach Federacji Rosyjskiej o kulturze ${ }^{16}$;

- z dnia 17 listopada 1995 r., nr 169-F3 o działalności architektonicznej Federacji Rosyjskiej ${ }^{17}$;

- z dnia 26 maja 1996 r., nr 54-F3 o Funduszu Muzealnym Federacji Rosyjskiej i muzeach Federacji Rosyjskiej ${ }^{18}$;

- z dnia 6 stycznia 1999 r., nr 7-F3 o ludowym rzemiośle artystycznym ${ }^{19}$;

- z dnia 13 marca 2006 r., nr 38-F3 o reklamie ${ }^{20}$;

- z dnia 18 grudnia 2006 r., nr 231-F3 o wejściu w życie

15 Закон РФ от 27 Аекабря 1991 г. N 2124-I О среАствах массовой информации, „ВеАомости СъезАа народных Аепутатов Российской ФеАерации и Верховного Совета Российской Федерации" 1992, nr 7 s. 300.

16 Закон РФ от 9 октября 1992 г. N 3612-І Основы законодатемьства Российской Федерации о культуре, „ВеАомости СъезАа народных Аепутатов Российской ФеАерации и Верховного Совета Российской ФеАерации" 1992, nr 46, s. 2615.

17 Федеральный закон от 17 ноября 1995 г. N 169-Ф3 Об архитектурной деятельности в Российской Федерации, „Собрание законодательства Российской Федерации" 1995, nr 47, s. 4473.

18 Федеральный закон от 26 мая 1996 г. N 54-Ф3 О Музейном фонАе Российской Федерации и музеях в Российской Федерации, „Собрание законодательства Российской Федерации” 1996, nr 22, s. 2591.

19 Федеральный закон от 6 января 1999 г. N 7-Ф3 О народных хуАожественных промыслах, „Собрание законодательства Российской Федерации" 1999, пг 2, s. 234.

20 Федерацьный закон от 13 марта 2006 г. N 38-Ф3 О рекмаме, „Собрание законодательства Российской Федерации” 2006, nr 12, s. 1232. 
części czwartej Kodeksu cywilnego Federacji Rosyjskiej²1;

- z dnia 30 grudnia 2015 r., nr 431-F3 o geodezji, kartografii i danych przestrzennych oraz o zmianie niektórych innych ustaw Federacji Rosyjskiej ${ }^{22}$.

Z punktu Rzeczpospolitej nie zauważa się zwykle oddziaływania na prawo Federacji Rosyjskiej aktów normatywnych Unii Europejskiej, z którą Federacja Rosyjska podpisała w dniu 24 czerwca 1994 r. umowę o partnerstwie i współpracy między wspólnotami europejskimi, ich państwami członkowskimi a Federacją Rosyjskąa ${ }^{23}$.

Problematyki prawa autorskiego dotykają także akty normatywne organu władzy wykonawczej, które wydane przed wejściem w życie części czwartej Kodeksu cywilnego Federacji Rosyjskiej zachowały moc obowiązującą w części niepozostającej w sprzeczności z przepisami tego kodeksu. Wskazać wśród należy dekrety Prezydenta Federacji Rosyjskiej:

- z dnia 7 października 1993 r., nr 1607 o polityce państwa w zakresie prawa autorskiego i praw pokrewnych ${ }^{24}$;

- z dnia 5 grudnia 1998 r., nr 1471 o środkach realizacji

21 Федеральный закон от 18 декабря 2006 г. N 231-Ф3 О введении в Аействие части четвертой ГражАанского кодекса Российской Федерации, „Собрание законодательства Российской Федерации” 2006, nr 52, s. 5497.

22 Федерахьный закон от 30.12.2015 N 431-Ф3 О геодезии, картографии и пространственных Аанных и о внесении изменений в отАецьные законодательные акты Российской Федерации, „Собрание законоАательства Российской Федерации” 2016, nr 1, s. 51.

23 Бюмлетень международных Аоговоров, 2008, nr 8, s. 3-74. Należy zauważyć, że w myśl dekretu Prezydenta Federacji Rosyjskiej z dnia 18 lipca 2008 r. Указ Президента РФ от 18.07.2008 N 1108 О совершенствовании ГражАанского кодекса Российской Федерации, „Собрание законодательства Российской Федерации” 2008, nr 29, s. 3482 za jeden z głównych kierunków prac legislacyjnych uznano potrzebę zbliżenia kodeksu cywilnego Federacji Rosyjskiej do przepisów prawa Unii Europejskiej.

24 Указ Президента РФ от 7.10.1993 N 1607 О государственной помитике в области охраны авторского права и смежных прав, „Российская газета", 14.10.1993, nr 192. 
praw twórców wykonawców, producentów fonogramów do wynagrodzenia za zwielokrotnianie do celów osobistych utworu audiowizualnego lub zapisu dźwiękowego dzieła $^{25}$.

Ponadto przywołać tu należy rozporządzenia Rady Ministrów Federacji Rosyjskiej, a mianowicie:

- z dnia 21 marca 1994 r., nr 2018 o minimalnych stawkach wynagrodzenia autorskiego za niektóre rodzaje korzystania z utworów literatury i sztuki ${ }^{26}$;

- z dnia 29 marca 1998 r., nr 524 o minimalnych stawkach wynagrodzenia twórców utworów kinematograficznych, których produkcja (zdjęcia) została dokonana do dnia 3 sierpnia $1992 \mathrm{r}^{27}$;

- z dnia 29 grudnia 2007 r., nr 992 o zatwierdzeniu zasad państwowej akredytacji organizacji zbiorowego zarządzania prawami autorskimi i prawami pokrewnymi ${ }^{28}$;

25 Указ Президента Российской Федерации от 05.12.1998 г. № 1471 О мерах по реализации прав авторов произведений, исполнителей и производителей фонограмм на вознагражАение за воспроизвеАение в Аичных целях аудиовизуального произведения ими звукозаписи произведения, „Собрание законодательства Российской Федерации” 1998, nr 49, s. 6007.

26 Постановление Правительства РФ от 21.03.1994 N 218 О минимальных ставках авторского вознаграждения за некоторые виды использования произведений митературы и искусства, „Собрание актов Президента и Правительства Российской Федерации”, 28.03.1994, nr 13.

27 Постановление Правительства РФ от 29 мая 1998 г. N 524 О минимальных ставках вознаграждения авторам кинематографических произведений, производство (съемка) которых осуществлено до 3 августа 1992 г., „Собрание законодательства Российской ФеАерации” 1998, nr 22, s. 2476.

28 Постанов ение Правитеньства РФ от 29.12.2007 N 992 Об утвержАении Положения о государственной аккредитации организаций, осуществляющих комлективное управление авторскими и смежными правами, а также об установцении преАемьного (максимального) размера сумм, удерживаемых аккредитованной организацией на покрытие необходимых расходов по сбору, распределению и выплате вознаграждения, а также сумм, которые направляются в специальные фонды, 
- z dnia 19 kwietnia 2008 r., nr 285 o zatwierdzeniu zasad wypłaty twórcy wynagrodzenia przy publicznej odsprzedaży oryginałów utworów plastycznych, autorskim rękopisów (autografów), utworów literackich i muzycznych ${ }^{29}$;

- z dnia 24 grudnia 2008 r., nr 1020 o państwowej rejestracji o rozporządzeniu prawem wyłącznym do wynalazku, wzoru użytkowego, wzoru przemysłowego, zarejestrowanej topografii układu scalonego, programu dla elektronicznych maszyn cyfrowych, bazy danych i bezumownego przejścia prawa wyłącznego do wynalazku, wzoru użytkowego, wzoru przemysłowego, znaku towarowego, znaku usługowego, oznaczenia miejsca pochodzenia towaru, zarejestrowanej topografii układu scalonego, programu dla elektronicznych maszyn cyfrowych, bazy danych ${ }^{30}$.

Przepisy dotykające praw autorskich Federacji Rosyjskiej tworzą obszerny, często nowelizowany i uzupełniany gąszcz normatywny, przez który trudno przedrzeć się nieuzbrojonym w maczety wiedzy prawniczej profanom.

„Собрание законодательства Российской Федерации” 2008, nr 2, s. 114.

29 Постанов ение Правитеньства РФ от 19.04.2008 N 285 Об утверждении Правим выплаты автору вознаграждения при перепродаже оригинацов произведений изобразительного искусства, авторских рукописей (автографов) китературных и музыкамьных произведений, „Собрание законодательства Российской ФеАерации” 2008, nr 17, s. 1880.

30 Постановление Правительства Российской Федерации от 24 Аекабря 2015 г. N 1416 о государственной регистрации распоряжения искиючительным правом на изобретение, полезную модель, промышменный образец, товарный знак, знак обслуживания, зарегистрированные топологию интеграцьной микросхемы, программу Аля ЭВМ, базу Аанных по договору и перехода искцючительного права на указанные результаты интелмектуацьной деятельности без Аоговора, „Собрание законодательства Российской ФеАерации” 2016, nr 1, s. 230. 


\section{Koncepcja autorskich praw majątkowych jako praw podmiotowych $w$ rosyjskim systemie prawnym}

Konwencja berneńska, w redakcji aktu paryskiego z 1971 r., jako przedmiot ochrony definiuje „dzieła literackie i artystyczne" obejmując tym pojęciem wszelkie dzieła literackie, naukowe i artystyczne, bez względu na sposób lub formę ich wyrażenia, takie jak książki, broszury i inne pisma; odczyty, przemówienia, kazania i inne dzieła tego rodzaju; dzieła dramatyczne lub dramatyczno-muzyczne; dzieła choreograficzne i pantomimy; dzieła muzyczne ze słowami lub bez słów; dzieła filmowe oraz zrównane z nimi dzieła wyrażane w podobny sposób jak film; dzieła rysunkowe, malarstwo, dzieła architektoniczne, rzeźby, dzieła rytownicze i litograficzne; dzieła fotograficzne oraz zrównane z nimi dzieła wyrażane w podobny sposób jak fotografia; dzieła sztuki użytkowej, ilustracje, mapy geograficzne, plany, szkice i dzieła plastyczne dotyczące geografii, topografii, architektury lub innych nauk ${ }^{31}$.

Definicja przedmiotu ochrony w ustawach państw członkowskich EaUG obejmuje dwa elementy - główne postanowienia dotyczące zakresu ochrony oraz otwartą listę przykładowych dzieł objętych ochroną. Przedmiotem ochrony rosyjskiego prawa autorskiego, w ramach otwartej listy przedmiotów ochrony, wymieniono utwory literackie, dramatyczne i dramatyczno-muzyczne, scenariusze, dzieła choreograficzne i pantomimy, muzyczne i słowno-muzyczne, audiowizualne, malarskie, rzeźbiarskie, graficzne, projektowe, komiksy; dekoracyjne i scenograficzne; architektoniczne i urbanistyczne, w tym projekty, rysunki, obrazy i modele; fotograficzne i uzy-

\footnotetext{
31 Art. 2, Akt paryski Konwencji berneńskiej..., op.cit.
} 
skane metodami podobnymi do fotografii; mapy geograficzne i inne; plany, szkice i utwory plastyczne związane z geografią i innymi naukami ${ }^{32}$. W tym samym ustępie, jednak w zdaniu wyraźnie wyłączonym z zakresu wspomnianej listy, zagwarantowano ochronę prawnoautorską programom komputerowym, które traktowane są jako utwory literackie.

Kodeks cywilny FR wymienia kategorie utworów, którym nie przyznaje ochrony prawnoautorskiej ${ }^{33}$, a mianowicie: oficjalnym dokumentom organów państwowych i organów samorządu lokalnego formacji gminnych, w tym ustawom, rozporządzeniom, orzeczeniom sądowym, innym materiałom o charakterze ustawodawczym, administracyjnym i sądowym, oficjalnym dokumentom organizacji międzynarodowych, a także ich oficjalnym tłumaczeniom; symbolom i znakom państwowym (flagom, emblematom, banknotom itp.), a także symbolom i znakom jednostek administracyjnych; dziełom sztuki ludowej (folklor), nieposiadającym konkretnych autorów; wiadomościom o zdarzeniach i faktach mających jedynie charakter informacyjny, np. wiadomościom o aktualnościach dnia, programach telewizyjnych, rozkładach jazdy itp.

Rosyjskie prawo autorskie obejmuje zarówno publikowane, jak i niepublikowane utwory wyrażone w dowolnej formie obiektywnej, w tym w formie pisemnej, ustnej ( $w$ formie publicznego ogłoszenia, publicznego wykonania i innej podobnej formy), w postaci obrazu, w postaci dźwięku - lub nagrania wideo w formie przestrzenno-przestrzennej. Do powstania, wykonywania i ochrony praw autorskich nie wymaga rejestracji pracy lub dokonania jakichkolwiek formalności ${ }^{34}$. W odniesieniu do programów komputerowych i baz danych rejestracja jest moż-

\footnotetext{
32 Art. 1259 ust. 1 KC FR.

33 Art. 1259 ust. 6 KC FR.

34 Art. 1259 ust. 3 KC FR.
} 
liwa na wniosek właściciela praw autorskich zgodnie z zasadami art. 1262 Kodeksu.

Rosyjski Kodeks cywilny reguluje zasady ochrony prawnej własności intelektualnej, w tym także prawa autorskiego. $\mathrm{O}$ ile prawa autorskie nie wymagają dla swojego powstania dokonania żadnych formalności, o tyle realizacja prawa oraz ochrona szeregu przedmiotów własności intelektualnej jest uzależniona od dokonania rejestracji państwowej (szerzej art. $1232 \mathrm{KC}$ FR). Programy komputerowe oraz bazy danych są wyjątkowym przedmiotem prawa autorskiego, gdyż spełniają one także wymogi innych kategorii własności intelektualnej i jako takie mogą być rejestrowane, choć rejestracja w tym przypadku ma charakter fakultatywny. W myśl art. 1262 KC FR uprawniony może według własnego uznania zarejestrować program lub bazę danych w federalnym organie wykonawczym właściwym ds. własności intelektualnej. Programy komputerowe i bazy danych zawierające informacje stanowiące tajemnicę państwową nie podlegają rejestracji państwowej. Osoba, która złożyła wniosek o rejestrację państwową (wnioskodawca), jest odpowiedzialna za ujawnianie informacji o programach komputerowych i bazach danych zawierających tajne informacje państwowe zgodnie z ustawodawstwem Federacji Rosyjskiej. Wniosek o państwową rejestrację programu komputerowego lub bazy danych (wniosek o rejestrację) musi odnosić się do jednego programu komputerowego lub do jednej bazy danych.

Wniosek o rejestrację musi zawierać: wniosek o państwową rejestrację programu komputerowego lub bazy danych wskazującej właściciela, a także autora, jeżeli nie odmówił on wymienienia go, oraz miejsce zamieszkania lub lokalizacji każdego z nich; zdeponowane materiały identyfikujące program komputerowy lub bazę danych, w tym streszczenie. Zasady dotyczące składania wniosku o rejestrację są ustalane przez federalny organ wykonawczy, który wdraża ramy prawne 
w dziedzinie własności intelektualnej. Na podstawie wniosku o rejestrację, federalny organ wykonawczy ds. własności intelektualnej sprawdza dostępność niezbędnych dokumentów i materiałów, a także ich zgodność $\mathrm{z}$ wymogami określonymi przez prawo. Jeśli weryfikacja jest pozytywna, określone władze federalne wprowadzają program komputerowy lub bazę danych odpowiednio do rejestru programów komputerowych i rejestru bazy danych, następnie wystawiają wnioskodawcy certyfikat rejestracji państwowej i publikują informacje o zarejestrowanym programie komputerowym lub bazie danych w oficjalnym biuletynie tego organu. Na wniosek określonego organu federalnego lub z własnej inicjatywy, autor lub inny posiadacz prawa autorskiego ma prawo do uzupełniania, wyjaśniania i poprawiania dokumentów i materiałów zawartych we wniosku o rejestrację do czasu państwowej rejestracji programu komputerowego lub bazy danych. Procedura rejestracji państwowej programów komputerowych i baz danych, formularze państwowych certyfikatów rejestracyjnych, wykaz informacji w nich wskazanych oraz lista informacji opublikowanych $\mathrm{w}$ oficjalnym biuletynie federalnego organu wykonawczego ds. własności intelektualnej są ustanawiane przez federalny organ wykonawczy, który wdraża ramy regulacyjne w dziedzinie własności intelektualnej.

Przeniesienie wyłącznego prawa do zarejestrowanego programu komputerowego lub bazy danych na inną osobę w drodze umowy lub bez umowy podlega rejestracji państwowej $\mathrm{w}$ federalnym organie wykonawczym dotyczącym własności intelektualnej. Na wniosek właściciela praw autorskich, federalny organ wykonawczy ds. własności intelektualnej wprowadza zmiany dotyczące informacji o posiadaczu praw autorskich lub o autorze programu komputerowego albo bazy danych, w tym nazwisko lub nazwę właściciela praw autorskich, jego siedzibę lub miejsce zamieszkania, nazwisko autora, adres do 
korespondencji, a także zmiany związane z korektą oczywistych i technicznych błędów, w rejestrze programów komputerowych lub rejestrze baz danych i certyfikatu rejestracji państwowej. Federalny organ wykonawczy ds. własności intelektualnej może wprowadzić zmiany do rejestru programów komputerowych lub rejestru baz danych w celu skorygowania oczywistych i technicznych błędów z własnej inicjatywy lub na wniosek dowolnej osoby, po uprzednim powiadomieniu posiadacza praw. Federalny organ wykonawczy ds. własności intelektualnej publikuje w oficjalnym biuletynie informacje dotyczące zmian wpisów w rejestrze programów komputerowych lub rejestrze bazy danych. Informacje wpisane do rejestru programów komputerowych lub do rejestru baz danych są uznawane za wiarygodne do chwili dowiedzenia ich nieprawdziwości. Wnioskodawca jest odpowiedzialny za dokładność informacji dostarczonych do rejestracji państwowej.

Rosyjski ustawodawca status twórcy dzieła nauki, literatury lub sztuki nadaje wyłącznie obywatelowi Federacji Rosyjskiej, w wyniku którego działalności twórczej utwór został stworzo$n y^{35}$.

W rosyjskim systemie prawa cywilnego, prawo podmiotowe wiązane jest ściśle z pojęciem stosunku cywilnoprawnego, nie stanowiąc zwykle samodzielnego odniesienia ${ }^{36}$. Jest to konsekwencją faktu przeciwstawiania, zwłaszcza w czasach radzieckich interesu jednostki chronionego przez prawa interesowi ogółu. W efekcie w doktrynie rosyjskiej przyjmuje się, że pojęcie stosunku cywilnoprawnego jest fundamentem

35 Art. 1257 KC FR.

36 Е.А. Суханов (red.), Российское гражданское право, t. I: Общая часть. Вешное право. Наследственное право. Интеллектуальные права. Аичные неимущественные права, Москва 2011, s. 121; Э.И. Иванов, Понятие субъективного права, „Марийский юридический вестник” 2011, nr 8, s. 182. 
teorii prawa cywilnego, przy czym najpełniej charakteryzuje ten stosunek prawo podmiotowe ${ }^{37}$. W literaturze rosyjskiej postrzegano prawo podmiotowe jako środek regulowania zachowań innych podmiotów w oparciu o normy prawa cywilnego, $\mathrm{w}$ celu zaspokojenia interesów uprawnionego. Akcentowano przy tym, że interesy te powinny być zgodne, a przynajmniej niesprzeczne z interesami państwa socjalistycznego. Dopiero w nieco późniejszych czasach zaczęto wiązać prawo podmiotowe z pojęciem sfery możności postępowania ${ }^{38}$, ewentualnie, jako zabezpieczoną przez państwo możność postępowania podmiotu stosunku cywilnoprawnego ${ }^{39}$. W prawie podmiotowym widziano niekiedy ustanowioną i zagwarantowaną przez normy prawa przedmiotowego szczególną możność postępowania, pozwalającą podmiotowi na zachowanie się w określony sposób i żądanie określonego zachowania od innych, a także na korzystanie z instrumentów społecznych, polegających na możliwości zwracania się do organów państwowych o ochronę osobistych interesów i potrzeb niesprzecznych z interesami i potrzebami społeczeństwa ${ }^{40}$. Współcześnie wydaje się przeważać pogląd, w myśl którego cywilne prawo podmiotowe stanowi „sferę możności postępowania podmiotów cywilnoprawnych" ${ }^{\text {"11 }}$. Niekiedy wskazuje się, że prawo podmiotowe to

37 Э.И. Иванов, Понятие субъективного права, „Марийский юриАический вестник" 2011, nr 8, s. 182.

38 С.Н. Братусь, О соотношении гражданской правоспособности и субъективных гражданских прав, „Советское Государство и Право” 1949, nr 8, s. 30-37.

39 Н.Г. Аєександров, Законность и правоотношение в советском обществе, Москва 1955, s. 108-109.

40 Н.И. Матузов, Аичность. Права. Аемократия. Теоретические проблемы субъективного права, Саратов 1972, s. 145.

41 С.С. Алексеев, Гражданское право, Москва 2009, s. 44; И.А. Зенин, Гражданское право Российской Федерации, Москва 2002, s. 28-29; М.Н. Марченко, Теория государства и права, Москва 2005, s. 322; Е.А. Суханов (red..), Российское гражданское право, t. I: Общая часть. 
przyznana jednostce, dla zabezpieczenia interesów prawnych sfera możności postępowania umożliwiająca podejmowanie przez uprawnionego określonych czynności oraz możności żądania określonego zachowania od osoby zobowiązanej ${ }^{42}$. Według dalej idących rozwiązań prawo podmiotowe obejmuje nie tylko możność podejmowania przez podmiot uprawniony określonych czynności zarówno faktycznych, jak i prawnych, lecz także możliwość żądania przez ten podmiot od innej osoby określonego zachowania się i wreszcie możność skorzystania z różnych środków ochrony lub przymusu państwowego w przypadku naruszenia prawa podmiotowego ${ }^{43}$. Efektem takiego stanowiska musi być podjęcie dociekań odnoszących się do znaczenia „uprawnienia” oraz stosunku tego pojęcia do prawa podmiotowego.

Prawo podmiotowe w doktrynie rosyjskiego prawa cywilnego postrzegane jest jako agregat dwóch lub trzech uprawnień, a mianowicie: uprawnienia do podejmowania własnych czynności, uprawnienia podmiotu do żądania określonego zachowania innych osób oraz niekiedy uprawnienia podmiotu do ochrony prawa podmiotowego. Dawało to asumpt do dwu- lub trójelementowej struktury każdego prawa podmiotowego ${ }^{44}$.

Вешное право. Наследственное право. Интеллектуальные права. Аичнье неимущественные права, Москва 2011, s. 121; А.Ф. ЧерАанцев, Теория государства и права, Москва 2001, s. 297-298.

42 С.С. Алексеев, Гражданское право, Москва 2009, s. 44; И.А. Зенин, Гражданское право Российской Федерации, Москва 2002, s. 28-29; М.Н. Марченко, Теория государства и права, Москва 2005, s. 322; Е.А. Суханов (red.), Российское гражданское право, t. I: Общая часть. Вешное право. Наследственное право. Интеллектуальные права. Аичные неимущественные права, Москва 2011, с. 121; А.Ф. ЧерАанцев, Теория государства и права, Москва 2001, s. 297-298.

43 Е.А. Суханов (red.), Российское гражданское право, t. I: Общая часть. Вешное право. Наследственное право. Интеллектуальнье права. Аичные неимущественные права, Москва 2011, s. 121; И.А. Зенин, Гражданское право Российской Федерачии, Москва 2002, s. 28-29

44 Е.А. Суханов (red.), Российское гражданское право, t. I: Общзая 
Nie wdając się w analizę poszczególnych koncepcji, co przekraczałoby zakres poczynionych rozważań, wypada jedynie stwierdzić, że za koncepcją dwuelementowej struktury prawa podmiotowego opowiedzieli się W.A. Biełow ${ }^{45}$, O.S. Joffe ${ }^{46}$ oraz A.W. Własowa ${ }^{47}$. Natomiast za trójelementową strukturą optowali: N.G. Aleksandrow ${ }^{48}$, I.A. Żenin ${ }^{49}$ i E.A. Suchanow ${ }^{50}$.

W doktrynie rosyjskiej wyróżnia się wśród praw podmiotowych, prawa rzeczowe i zobowiązaniowe, prawa wyłączne i prawa pierwszeństwa, a także prawa bezwzględne i względ$\mathrm{ne}^{51}$. Ważny wydaje się podział na prawa majątkowe i niemajątkowe, gdzie jako kryterium podziału wskazuje się związanie niemajątkowych praw podmiotowych z osobą, której te prawa przysługują. Prawa te nie poddają się konkretnej wycenie majątkowej i mają charakter praw bezwzględnych ${ }^{52}$. Natomiast

часть. Вещное право. Наследственное право. Интеллектуальные права. Аичные неимущественнье права, Москва 2011, s. 121.

45 В.А. Белов, Гражданское право: учебник. Общая часть, Москва 2002, s. 538-540.

46 О.С. Иоффе, [w:] О.С. Иоффе, А.М. Шаргородский, Вопросы теории права, Москва 1961, s. 225.

47 А.В. Власова, Структура субъективного гражданского права, Ярославиь 1998, s. 39.

48 Н.Г. Ацександров, Законность и правоотношение в советском обшестве, Москва 1955, s. 107-109.

49 И.А. Зенин, Гражданское право Российской Федерации, Москва 2002, s. 28-29.

50 Е.А. Суханов (red.), Гражданское право, t. 1: Общая часть, Москва 2006, s. 121.

51 В.К. Райхер, Абсолютные и относительные права (к проблеме деления хозяйственных прав). В особенности применительно к советскому праву, „Известия Экономического Факультета АПИ им. М.И. КаАиниа" 1928, t. 1, nr 7, s. 303-304 (reprint „Вестник гражданского права” 2007, t. 7, nr 2, s. 144-204); В.А. Бемов, Гражданское право, t. I: Общая часть, Введение в гражданское право, Москва 2016, s. 501; О.С. Иоффе, Правоотношение по советскому гражданскому праву, АенинграА 1949, s. 103-104.

52 Ю.С. Гамбаров, Курс гражданского права, t. I: Часть общуая, Санкт-Петербург 1911, s. 85-87. 
majątkowe prawa majątkowe mogą być przedmiotem zbycia i poddają się wycenie. Mogą być one także ograniczane czasowo $^{53}$. Na gruncie rosyjskiego prawa cywilnego wyróżnia się także prawa podmiotowe rzeczowe i zobowiązaniowe ${ }^{54}$ oraz prawa wyłączne i prawa pierwszeństwa ${ }^{55}$. Duże znaczenie przypisuje się również podziałowi praw ze względu na sposób nabycia na pierwotne i pochodne ${ }^{56}$. Wreszcie wyróżnia się na bycie translatywne i konstytutywne ${ }^{57}$.

Podziału praw podmiotowych, a w szczególności instytucja prawa wyłącznego, wypracowana w końcu XIX w. wiąże się z własnościową koncepcją prawa autorskiego, w myśl której prawo to ujmowane jest na wzór prawa własności do rzeczy ${ }^{58}$.

\section{Autorskie prawa majątkowe}

Prawo rosyjskie nie formułuje definicji legalnej przedmiotu praw autorskich, ograniczając się do stwierdzenia, że są nimi utwory literackie, naukowe i artystyczne, niezależnie od ich wartości przeznaczenia lub sposobu wyrażenia. Wskazano przy tym przykładowo, że do utworów takich zalicza się m.in. utwory dramatyczne, muzyczno-dramatyczne, scenariusze, utwory choreograficzne i pantomimiczne, utwory muzyczne z tekstem i bez tekstu, audiowizualne, malarskie, rzeźbiarskie, graficzne, designerskie, historie rysunkowe, komiksy i inne utwory sztuk

53 С.А. Судариков, Авторское право, Москва 2013, s. 135-136.

54 В.П. Грибанов, Осуществление и защита гражданских прав, Иза. 2-е, Москва 2001, s. 293-294.

55 Ibidem, s. 294-295.

56 С.А. Степанов, Гражданское право, t. 2, Москва 2011, s. 127.

57 Б.Б. Черепахин, Правопреемство по советскому гражданскому праву, Москва 1962, s. 55-62.

58 Г.Ф. Шершеневич, Авторское право на литературные произведения, Казань 1891, s. $72-73$ (Сост. В.А. Белов - Москва 2019). 
plastycznych, utwory sztuki użytkowej i scenograficzne, architektoniczne, urbanistyczne oraz ogrodowo-parkowe, także w postaci planów, projektów, rysunków, makiet, a także utworu fotograficzne i uzyskane w sposób analogiczny do fotografii, mapy geograficzne i inne, plany, szkice i utwory plastyczne odnoszące się do geografii i topografii oraz inne utwory ${ }^{59}$.

W Federacji Rosyjskiej prawa autorskie majątkowe podlegają ochronie w ciągu całego życia autora oraz siedemdziesiąt lat po jego śmierci, licząc od 1 stycznia roku następującego po roku śmierci autora ${ }^{60}$. Prawa autorskie majątkowe do utworu współautorskiego podlegają ochronie przez całe życie autorów oraz siedemdziesiąt lat po śmierci współautora, który przeżył pozostałych współautorów, licząc od 1 stycznia roku następującego po roku jego śmierci.

W przypadku utworu opublikowanego anonimowo lub pod pseudonimem, rosyjski ustawodawca przyznaje ochronę praw autorskich majątkowych przez okres siedemdziesięciu lat, licząc od dnia 1 stycznia roku następującego po roku jego opublikowania. Jeżeli w tym czasie autor utworu, opublikowanego anonimowo lub pod pseudonimem, ujawni swoją tożsamość lub jego tożsamość nie pozostawi dalej żadnych wątpliwości, prawo autorskie majątkowe będzie chronione na zasadach podstawowych, czyli przez okres siedemdziesięciu lat po śmierci twórcy.

Kodeks cywilny FR przewiduje najszerszą ochronę praw autorskich majątkowych do utworu ogłoszonego po śmierci autora, gdyż podlegają one ochronie przez okres siedemdzie-

59 К.С. Безик, Авторские произведения как объект авторского права, [w:] Актуальные проблемы правотворчества и правоприменительной деятельности. Научно-практическая конференция, посвященная 90-летию юридического образования в ИГУ, red. Н.Э. Шишкин, Иркутск 2008, s. 141; И.А. Зенин, Гражданское право. Обшая часть, Москва 2019, sc. 284.

60 Art. 1281 ust. 1 KC FR. 
sięciu lat po opublikowaniu dzieła, począwszy od 1 stycznia roku następującego po roku jego opublikowania ${ }^{61}$. Warunkiem objęcia ochroną takiego dzieła jest fakt, że utwór został opublikowany w ciągu siedemdziesięciu lat po śmierci autora.

W prawie rosyjskim także można znaleźć piętno smutnej przeszłości. Jeżeli autor utworu został represjonowany i pośmiertnie zrehabilitowany, okres ważności praw autorskich majątkowych uznaje się za przedłużony. Siedemdziesięcioletni okres ochrony praw autorskich majątkowych liczony jest od dnia 1 stycznia roku następującego po roku rehabilitacji autora utworu ${ }^{62}$. Natomiast jeżeli autor pracował podczas Wielkiej Wojny Ojczyźnianej lub brał w niej udział, okres ochrony praw autorskich majątkowych jest przedłużony o cztery lata ${ }^{63}$.

\section{Podsumowanie}

Nie da się zaprzeczyć, że ostatnie regulacje podejmowane w prawie Federacji Rosyjskiej w zakresie ochrony własności intelektualnej w ogólności, a w prawie autorskim w szczególności prowadzą do zbliżenia przyjętych rozwiązań prawnych ze standardami europejskimi. Pamiętać jednak należy, że Federacja Rosyjska wchodzi w skład w Euroazjatyckiej Unii Gospodarczej. Niewątpliwie w ramach tej organizacji odgrywa rolę dominującą, jednak nie wolno także zapominać, że istnieją poważne różnice między rozwiązaniami prawnymi państw wchodzących w skład Euroazjatyckiej Unii Gospodarczej i jak dowiodła to ostatnio Ksenia Kakareko podejmowanie próby ujednolicenia ustaw dotyczących praw autorskich w państwach tej Unii powiodły się jedynie w bardzo ograniczonym

\footnotetext{
61 Art. 1281 ust. 3 KC FR.

62 Art. 1281 ust. 4 KC FR.

63 Art. 1281 ust. 5 KC FR.
} 
zakresie. Czy i w jakim kierunku dojdzie do unifikacji trudno dzisiaj przewidywać ${ }^{64}$.

\section{Bibliografia}

Kakareko K., Standardy ochrony wtasności intelektualnej w państwach członkowskich Euroazjatyckiej Unii Gospodarczej, [w:] Polityka, prawo, kultura i bezpieczeństwo na obszarze poradzieckim, red. T. Bodio, J. Marszałek-Kawa, Toruń 2018.

Александров Н. Г., Законность и правоотношение в советском обшестве, Москва 1955.

Алексеев С.С., Гражданское право, Москва 2009.

Балгай М.В., Конституционное право Российской Федерации, Москва 2007.

Безик К.С., Авторские произведения как объект авторского права, [w:] Актуальные проблемы правотворчества и правоприменительной деятельности. Научно-практическая конферениия, посвященная 90-летию юридического образования в ИГУ, red. Н.Э. Шишкин, Иркутск 2008.

Белов В.А., Гражданское право: учебник. Общая часть, Москва 2002.

Белов В.А., Гражданское право, t. I: Общая часть, Введение в гражданское право, Москва 2016.

Братусь С.Н., О соотношении гражданской правоспособности и субъективных гражданских прав, „Советское Государство и Право” 1949, nr 8.

64 K. Kakareko, Standardy ochrony własności intelektualnej w państwach członkowskich Euroazjatyckiej Unii Gospodarczej, [w:] Polityka, prawo, kultura i bezpieczeństwo na obszarze poradzieckim, red. T. Bodio, J. Marszałek-Kawa, Torun 2018, s. 44-68. 
Вцасова А.В., Структура субъективного гражданского права, Ярославль 1998.

Гамбаров Ю.С., Курс гражданского права, t. I: Часть общуая, Санкт-Петербург 1911.

Грибанов В.П., Осуществление и зашита гражданских прав, ИзА. 2-е, Москва 2001.

Зенин И.А., Гражданское право Российской Федерации, Москва 2002.

Зенин И.А., Гражданское право. Общая часть, изА. 19, Москва 2019.

Иванов Э. И., Понятие субъективного права, „Марийский юридический вестник", 2011, nr 8.

Иоффе О.С., [w:] О.С. Иоффе, А.М. Шаргородский, Вопросы теории права, Москва 1961.

Иоффе О.С., Правоотношение по советскому гражданскому праву, АенинграА 1949.

Марченко М.Н., Теория государства и права, Москва 2005 Матузов Н.И., Аичность. Права. Аемократия. Теоретические проблемы субъективного права, Саратов 1972.

Райхер В.К., Абсолютные и относительнысе права (к проблеме деления хозяйственных прав). В особенности применительно к советскому праву, „Известия Экономического Факуиьтета АПИ им. М. И. Кациниа" 1928, nr 7, t. 1 (reprint «Вестник гражданского права" 2007, nr 2, t. 7 .

Степанов С.А., Гражданское право, т. 2, Москва 2011

Судариков С.А., Авторское право, Москва 2013.

Суханов Е.А. (red.), Гражданское право, t. 1: Общяая часть, Москва 2006.

Суханов Е.А. (red.), Российское гражданское право, t. I: Общая часть. Вещное право. Наследственное право. Интеллектуальные права. Аичные неимущественные права, Москва 2011. 
Черданцев А.Ф., Теория государства и права, Москва 2001. Черепахин Б.Б., Правопреемство по советскому гражданскому праву, Москва 1962.

Шершеневич Г.Ф., Авторское право на литературные произведения, Казань 1891 (Сост. В.А. Белов - Москва 2019).

\begin{abstract}
Abstrakt
Podstawy normatywne prawa autorskiego w Federacji Rosyjskiej są złożone. Stanowią je Konstytucja, umowy międzynarodowe zawarte przez Federację Rosyjską oraz część czwarta kodeksu cywilnego Federacji Rosyjskiej. Problematyki prawa autorskiego dotyczą także normy licznych ustaw federalnych i rozporządzeń Rady Ministrów. Federacja Rosyjska funkcjonuje w ramach Euroazjatyckiej Unii Gospodarczej i kieruje się wypracowywanymi w jej ramach normami i zasadami.
\end{abstract}

Słowa kluczowe: prawo autorskie, własność intelektualna, kodeks cywilny, Federacja Rosyjska, Euroazjatycka Unia Gospodarcza, autorskie prawa majątkowe, prawa podmiotowe

\begin{abstract}
The normative foundations of copyright in the Russian Federation are complex. They are Constitution, international agreements concluded by the Russian Federation and part four of the Civil Code of the Russian Federation. Copyright issues also apply to the norms of numerous federal laws and ordinances of the Council of Ministers. The Russian Federation operates within the Eurasian Economic Union and is guided by the norms and principles developed within it.
\end{abstract}

Keywords: copyright, intellectual property, civil code, Russian Federation, Eurasian Economic Union, proprietary copyrights, subjective rights 